Andrews University

Digital Commons @ Andrews University

2016

\title{
An Analysis of Adventist Mission Methods in Brazil in Relationship to a Christian Movement Ethos
}

Marcelo Eduardo da Costa Dias

Andrews University, diasm@andrews.edu

Follow this and additional works at: https://digitalcommons.andrews.edu/dissertations

Part of the Missions and World Christianity Commons

\section{Recommended Citation}

Costa Dias, Marcelo Eduardo da, "An Analysis of Adventist Mission Methods in Brazil in Relationship to a Christian Movement Ethos" (2016). Dissertations. 1598.

https://digitalcommons.andrews.edu/dissertations/1598

https://dx.doi.org/10.32597/dissertations/1598

This Dissertation is brought to you for free and open access by the Graduate Research at Digital Commons @ Andrews University. It has been accepted for inclusion in Dissertations by an authorized administrator of Digital Commons@ Andrews University. For more information, please contact repository@andrews.edu. 


\section{ABSTRACT \\ AN ANALYSIS OF ADVENTIST MISSION METHODS IN BRAZIL IN RELATIONSHIP TO A CHRISTIAN MOVEMENT ETHOS}

by

Marcelo E. C. Dias

Adviser: Bruce Bauer 


\title{
ABSTRACT OF GRADUATE RESEARCH
}

Dissertation

\author{
Andrews University
}

Seventh-day Adventist Theological Seminary

\section{Title: AN ANALYSIS OF ADVENTIST MISSION METHODS IN BRAZIL IN RELATIONSHIP TO A CHRISTIAN MOVEMENT ETHOS}

Name of researcher: Marcelo E. C. Dias

Name and degree of faculty chair: Bruce Bauer, DMiss

Date completed: May 2016

In a little over 100 years, the Seventh-day Adventist Church in Brazil has grown to a membership of $1,447,470$ (December 2013), becoming the country with the second highest total number of Adventists in the world. Very little academic research has been done to study or analyze the growth and development of the Adventist church in Brazil. In terms of its mission methods, what is the Christian movement ethos that fostered this development in Brazil? How can it continue to foster Adventist church growth in Brazil in spite of contextual changes?

As a missiological study that reflects typical interdisciplinarity crossing traditional boundaries of academic disciplines to borrow methods and insights and apply them toward a better understanding of a specific problem, this study employs Gailyn van 
Rheenen's Missional Helix and intertwines theological reflection, cultural analysis, historical perspective, and strategy formation within the context of the practice of ministry. The first part of this research is a biblico-historical overview of the character of Christian movements followed by a socio-religious systematization of the ethos of Christian movements. The third part focuses on the ethos of the Adventist movement in Brazil including a description and analysis of its mission methods. The present study analyzes five major mission methods used by the Adventist Church in Brazil from 1895 to 2007 based on the characteristics of an Adventist missionary movement ethos in order draw lessons to face the contemporary contextual challenges.

A brief analysis of the Adventist movement in Brazil, according to the proposed ethos model (confession of Jesus as Savior, Lord, and Priest; a missional-incarnational impulse of the soon coming of Jesus; an apostolic movement as part of the Great Controversy; communitas as a reflection of the will of God for relationships as described in God's commandments; organic systems according to spiritual gifts; and disciple making in preparation for eternity), suggests specific findings. Clearly, the Adventist Church has grown and developed as it has relied on different mission methods (literature evangelism, public evangelism, radio and TV evangelism, metropolitan evangelism, and integrated evangelism). And, even after discounting some of the obviously triumphalist enthusiasm found in the church leaders' reports and official sources of information, one is able to identify signs of a movement motivated by its mission.

In many ways, the overall lesson of this analysis is the importance of fostering mission as a way of living that is at the core of an Adventist movement and developing methods based on a biblical understanding of Christianity that will develop movements 
with a missionary ethos. In spite of the somewhat positive analysis of the Adventist movement ethos in Brazil, it is clear that there is much room for improvement in each area. This is especially important in face of the realization of the ideal biblical standards and the current contextual changes. A sign that the Adventist movement in Brazil has developed a true Christian ethos and a mature missiological understanding would be its significant missionary-sending activity to the world. 
Andrews University

Seventh-day Adventist Theological Seminary

\title{
AN ANALYSIS OF ADVENTIST MISSION METHODS IN BRAZIL IN RELATIONSHIP TO A CHRISTIAN MOVEMENT ETHOS
}

\author{
A Dissertation \\ Presented in Partial Fulfillment \\ of the Requirements for the Degree \\ Doctor of Philosophy
}

by

Marcelo E. C. Dias

May 2016 
(C) Copyright by Marcelo E. C. Dias 2016 All Rights Reserved 


\title{
AN ANALYSIS OF ADVENTIST MISSION METHODS IN BRAZIL IN RELATIONSHIP TO A CHRISTIAN MOVEMENT ETHOS
}

\author{
A dissertation \\ presented in partial fulfillment \\ of the requirements for the degree \\ Doctor of Philosophy
}

by

Marcelo E. C. Dias

APPROVAL BY THE COMMITTEE:

Faculty Adviser,

Bruce L. Bauer

Department of World Mission, Chair

Wagner Kuhn,

Professor of World Mission and

Intercultural Studies

Denis Fortin,

Professor of Theology
Director, PhD/ThD Program

Thomas Shepherd

Dean, SDA Theological Seminary

Jiří Moskala

Date approved 
To my wife Claudia and my daughter Alissa

for an academic journey together that shaped

our love and our lives

forever. 


\section{TABLE OF CONTENTS}

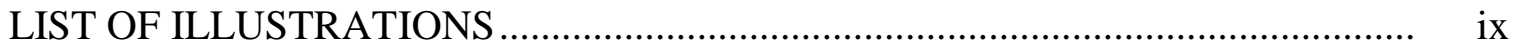

LIST OF ABBREVIATIONS ....................................................................

ACKNOWLEDGMENTS ........................................................................

PART I. THE CHARACTER OF CHRISTIAN MOVEMENTS:

A BIBLICO-HISTORICAL OVERVIEW

Chapter

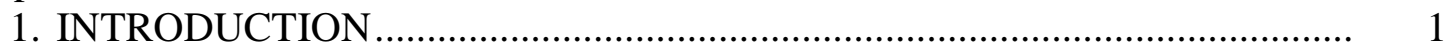

Background to the Problem ............................................................. 1

Research Questions .......................................................................... 4

Statement of Problem......................................................................... 4

Purpose Statement........................................................................ 4

Scope and Limitations................................................................... 5

Conceptual Framework ................................................................... 5

Methodology .......................................................................... 11

2. THE BEGINNING OF CHRISTIANITY: THE RESHAPING OF A WAY

OF BEING IN THIS WORLD ............................................................... 13

Background of Jesus' Times ............................................................... 14

Historical Developments............................................................ 14

Jewish Worldview.................................................................... 17

The People of God: The Controlling Story ................................ 20

Temple, Land, and the Torah: Their Symbols ........................... 22

Missionary Zeal: Their Hope …................................................ 23

John the Baptist........................................................................ 26

Jesus Christ and His Mission .............................................................. 29

Jesus Christ ........................................................................ 30

Jesus' Message ........................................................................ 32

Jesus' Ministry .................................................................... 38

Jesus' Commission....................................................................... 43

The Original Character of Christianity ................................................ 46 
The Early Christians ………………….................................................. 52

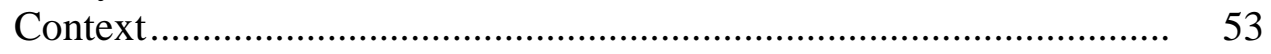

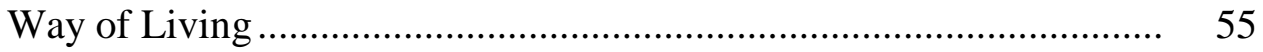

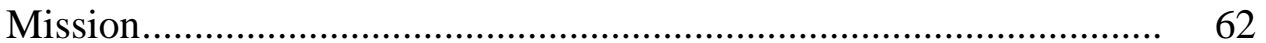

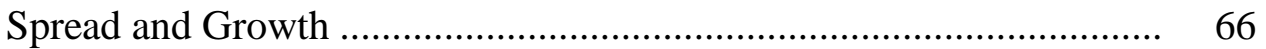

Christianity Becomes a Movement ...................................................... 69

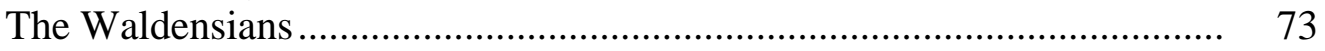

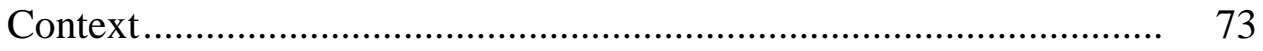

Way of Living and Mission ............................................................ $\quad 75$

A Restorationist Missionary Movement of the Middle Ages .............. 80

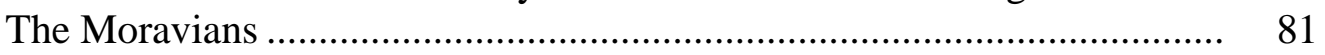

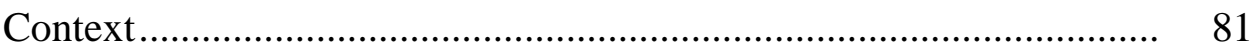

Way of Living and Mission ............................................................ 83

One of the Greatest Missionary Revivals in Protestant History ……... 86

True Christian Missionary Movements throughout History ....................... $\quad 88$

4. PRESENT GLOBAL CHRISTIANITY: BEING IN THIS WORLD IN THE TWENTY-FIRST CENTURY.............................................................. 90

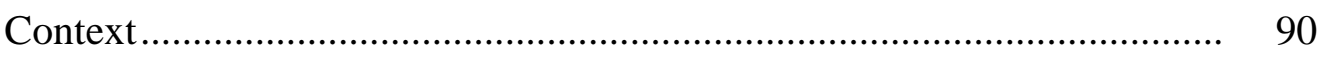

Philosophical Context .................................................................... 91

Social Context .......................................................................... 92

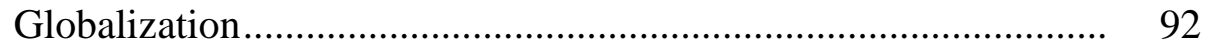

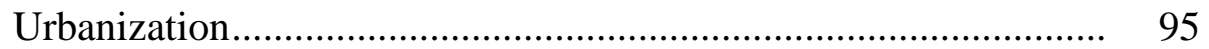

Demographics ........................................................................ 96

Religious Context....................................................................... 97

General Trends ……......................................................... 98

The Global Christian Presence ..................................................... 101

The Southern Christian Center.................................................... 102

Way of Living and Mission ................................................................. 104

Majority World Christians ............................................................... 104

The Unfinished Christian Mission ...................................................... 109

A Twenty-First Century Missionary Movement That Is a True

Expression of Original Christianity? ................................................... 114

PART II. THE ETHOS OF CHRISTIAN MOVEMENTS: A SOCIO-RELIGIOUS SYSTEMATIZATION

5. THE ETHOS OF CHRISTIAN MOVEMENTS ............................................. 121

Culture, Worldview, and Ethos.......................................................... 121

Socio-Religious Movements............................................................... 133



Life Cycle of Movements .............................................................. 137 
Ethos of Christian Movements............................................................ 142

Alan Hirsch's Model........................................................................ 144

Confession That Jesus Is Lord ....................................................... 146

Missional-Incarnational Impulse .................................................... 148

Apostolic Environment ……………………………………....... 150

Organic Systems …………………………………............... 152

Communitas, Not Community ......................................................... 155

Disciple Making ......................................................................... 157

Assumptions of Hirsch's Model ....................................................... 159

6. THE ETHOS OF THE SEVENTH-DAY ADVENTIST MOVEMENT ............ 162

The Rise of Adventism ......................................................................... 163

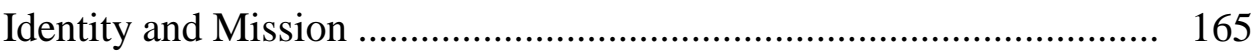

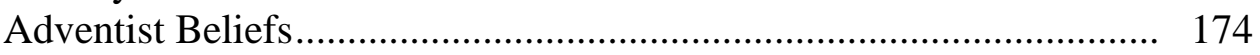

Adventist Beliefs and Mission ........................................................ 177

Great Controversy .................................................................. 179

Jesus' Priestly Ministry............................................................... 180

Imminent Second Coming of Jesus............................................... 181

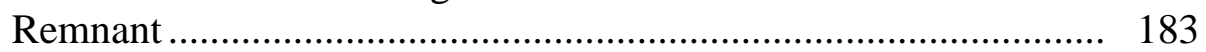

Three Angel's Messages ............................................................... 186

Toward a Model of Seventh-day Adventist Movement Ethos.................... 189

PART III. THE ETHOS OF THE ADVENTIST MOVEMENT

IN BRAZIL: A REVIEW OF MISSION METHODS

7. THE ETHOS OF THE SEVENTH-DAY ADVENTIST MOVEMENT IN BRAZIL BETWEEN 1893 AND 1942 ……………................................... 201

Literature Evangelism (1893) .............................................................. 203

Contextual Dynamics in Brazil: The First Republic........................... 204

Contextual Dynamics in the Church: Entering Brazil .......................... 205

Mission Method ........................................................................ 207

Jesus: Lord, Savior, and Priest ..................................................... 208

Missional-Incarnational Impulse of the Coming of Jesus............... 209

Apostolic Environment within the Great Controversy .................. 212

Community for God .................................................................. 213

Spiritual Organic Systems............................................................. 214

Disciple-making for Eternity …………..................................... 217

Public Evangelism (1927)................................................................ 220

Contextual Dynamics in Brazil: Getúlio Vargas and the Estado

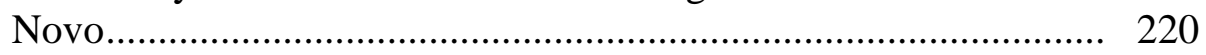

Contextual Dynamics in the Church: Multiplying the Reach ............... 221

Mission Method ……………………………………………..... 222

Jesus: Lord, Savior, and Priest and

Missional-Incarnational Impulse of the Coming of Jesus............... 223

Apostolic Environment within the Great Controversy .................. 226

Spiritual Organic Systems............................................................ 229 


\section{THE ETHOS OF THE ADVENTIST MOVEMENT BETWEEN 1943} AND 2007

Radio and Television Evangelism (1943)

Contextual Dynamics in Brazil: The Second Republic and

Military Rule

232

Contextual Dynamics in the Church: Navigating Instability .............. 233

Mission Method ............................................................................. 235

Jesus: Lord, Savior, and Priest .................................................. 236

Missional-Incarnational Impulse of the Coming of Jesus.............. 237

Apostolic Environment within the Great Controversy ................. 240

Spiritual Organic Systems.......................................................... 242

Community for God and Disciple-making for Eternity ............... 245

Metropolitan Evangelism (1980) ...................................................... 248

Contextual Dynamics in Brazil: Redemocratization......................... 248

Contextual Dynamics in the Church: Consolidating Growth ............. 249

Mission Method ............................................................................... 250

Jesus: Lord, Savior, and Priest ............................................... 252

Missional-Incarnational Impulse of the Coming of Jesus.............. 253

Apostolic Environment within the Great Controversy ................. 255

Spiritual Organic Systems...................................................... 256

Community for God and Disciple-making for Eternity ................ 261

Integrated Evangelism (1999) ........................................................ 262

Contextual Dynamics in Brazil: Economic Stabilization .................. 262

Contextual Dynamics in the Church: Seeking Integration ................ 263

Mission Method ............................................................................... 264

Missional-Incarnational Impulse of the Coming of Jesus.............. 265

Apostolic Environment within the Great Controversy ................. 266

Jesus: Lord, Savior, and Priest and Spiritual Organic Systems ...... 266

Community for God and Disciple-making for Eternity ................ 269

9. THE ETHOS OF THE ADVENTIST MOVEMENT IN BRAZIL: A MISSIOLOGICAL ANALYSIS, CONCLUSION, AND

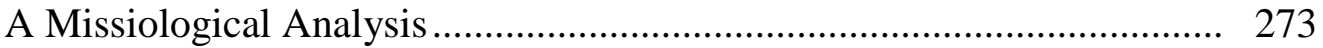

A Portfolio of Methods ................................................................... 273

The Adventist Movement Ethos Model in Brazil............................. 277

Christ: Savior, Lord, and Priest................................................. 278

Missional-Incarnational Impulse of the Coming of Jesus.............. 279

Apostolic Environment within the Great Controversy ................ 283

Spiritual Organic Systems....................................................... 285

Community for God .......................................................... 287

Disciple-making for Eternity ................................................ 289

Conclusion 


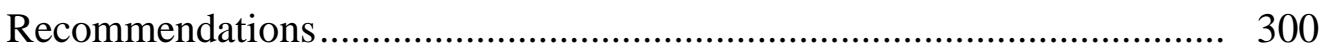

Mission as a Way of Being in the World ............................................ 300

Mission Methods and a Movement Ethos........................................... 302

Christ: Savior, Lord, and Priest...................................................... 302

Missional-Incarnational Impulse of the Coming of Jesus............... 304

Apostolic Environment within the Great Controversy .................. 305

Spiritual Organic Systems.......................................................... 306

Community for God ............................................................ 307

Disciple-making for Eternity ........................................................ 308

A Missionary-Sending Movement ................................................... 310

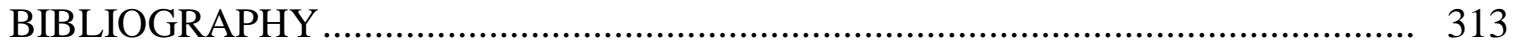

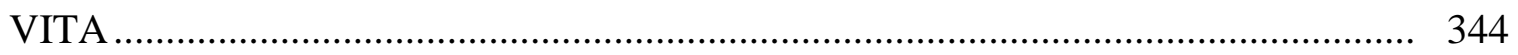




\section{LIST OF ILLUSTRATIONS}

1. Van Rheenen's Missional Helix..........................................................................

2. Dimensions of Worldview and Ethos .............................................................. 129

3. Hirsch's Model of a Christian Movement Ethos................................................. 146

4. Toward a Model of Seventh-day Adventist Missionary Movement Ethos............ 196

5. Adventist Mission Methods in Brazil ............................................................. 274

6. The Sigmoid Curve Resultant from Rekindling an Adventist Missionary Movement Ethos................................................................................... 299 


\section{LIST OF ABBREVIATIONS}

$\begin{array}{ll}\text { ADRA } & \text { Adventist Development and Relief Agency } \\ \text { APEPT } & \text { apostolic, prophetic, evangelistic, pastoral, and teaching/didactic } \\ \text { DNA } & \text { Hereditary material in humans } \\ \text { HIV/AIDS } & \text { Acquired Immunodeficiency Syndrome/Human Immunodeficiency Virus } \\ \text { mDNA } & \text { Missional hereditary material in humans } \\ \text { MV } & \text { Missionary Volunteer } \\ \text { SDA } & \text { Seventh-day Adventist }\end{array}$




\section{ACKNOWLEDGEMENTS}

This dissertation, a milestone in my life, is an individual work that would not have been possible without the guidance and support of a number of people to whom I am very grateful.

Thank you to Andrews University professors, especially those from the World Mission department. You have shaped my missiological understanding in your classes, hallway conversations, and international trips. In our interactions you have repeatedly introduced me to people, ideas, research, tools, missionary challenges, and most importantly, God. Thanks for giving me the opportunity to dive into the fascinating world of service and dedication to the spreading of God's kingdom. My deepest gratitude to my advisers. Dr. Rudi Maier for your analytical skills and friendship; Dr. Bruce Bauer for your editorial skills and advice; Dr. Wagner Kuhn for your vision and insights; Dr. Denis Fortin for your theological commitment and availability.

I would like to express my gratitude to the leaders of Adventist Church in Brazil, at the South American Division (SAD), the Central Brazil Union (CBU), Brazil Adventist University (BAU), and the Latin-American Adventist Theological Seminary (LATS), for sponsoring and supporting my family and I throughout this program. A special thanks to Elder Domingos José de Souza, CBU's president, for his support; Elder José Paulo Martini, BAU's president, for taking on the challenge of investing in the education of Theology professors and believing in the missionary purpose of the Adventist Church and institutions; Dr. Alberto R. Timm and Dr. Reinaldo Siqueira for the discussions about research topics and your visits while at Andrews University; Dr. Amim Rodor for the invitation to teach in the School of Theology in a time when that was only part of our 
wildest dreams and for recommending us for the doctoral program; and Dr. Emilson Reis for your continuous encouragement.

I would like to thank my family for the privilege of having a close identity with the ministry of Seventh-day Adventist Church. That story begins with my maternal German great-grandparents in Southern Brazil. It continues with my grandparents' stories of dedication as public evangelists to large parts of Brazil under less-than-ideal ministerial circumstances which have profoundly inspired me. My parents' teaching, by word and example, has helped me develop the type of love for the church that is always looking for ways to help it fulfill God's ideal in mission. Through their visionary ministerial understanding and practice in Brazil, they instilled in me from a very early age the passion for learning and the importance of looking beyond one's own culture, which made me dream of learning about and serving people in different places. My brother, a third-generation pastor, and my sister-in-law's dedication to the Lord's ministry demonstrates how much they believe in the mission of our church - this too is motivation to me.

I would also like to thank my wife and my daughter for partnering in this journey. Claudia and Alissa's faith are an inspiration for their simplicity and depth. During this academic endeavor far away from our relatives, my wife and my daughter have taught me when nobody was around. Many times my peace came from sitting and watching Alissa grow up (she was 4-months-old when I began the program) while I worked on our "second child"- this dissertation.

Finally, I would like to express my gratitude to everyone else who was part of this journey. Teachers and professors, both in Brazil and in the United States, who have 
helped foster my interest for the academic world throughout my career. Colleagues in ministry and in school, both in Brazil and in the United States, who have helped strengthen my conviction in God's missionary plan through His people. A special thanks to the churches I belonged to and ministered at - they were important reference points to my experience.

The divine blessing of dedicating a few years exclusively to conducting research about God's mission is a privilege and a responsibility. All praise and glory be to Him who loves so unconditionally and sacrificially to not only be the utmost missionary but to also reveal about, invite into, and guide His people in engaging in His mission to others. There has not been a moment during this doctoral program that my family and I have not felt His abundant grace in our lives. To Him and His service we rededicate ourselves today. 
PART I: THE CHARACTER OF CHRISTIAN MOVEMENTS:

A BIBLICO-HISTORICAL OVERVIEW 


\section{CHAPTER 1}

\section{INTRODUCTION}

\section{Background to the Problem}

In a little over 100 years, the Seventh-day Adventist Church ${ }^{1}$ in Brazil has grown to a membership of $1,447,470$ (December 2013), becoming the country with the second highest total number of Adventists in the world. ${ }^{2}$ Something happened. The message that was first shared in the small state of Santa Catarina, where a package of Die Stimme der Wahrheit (The Voice of Truth) magazines was delivered sometime between 1879 and 1880, spread to the whole nation. The first ordained Adventist minister, Frank Westphal, arrived in $1895 .{ }^{3}$ The Adventist Church's development and growth in more than one dimension has been the result of many different factors, methods, and experiences. ${ }^{4}$ As Adventists blazed new trails in new territories they spread the seed of the gospel

${ }^{1}$ From now on referred to as Adventist Church.

${ }^{2}$ General Conference of Seventh-day Adventists, Annual Statistical Report (2015) (Silver Spring, MD: Author), 80. According to the same report, the Adventist movement in India has 1,500,830 members.

${ }^{3}$ Germano Streithorst, “O Início da Nossa Obra,” Revista Adventista, March 1958, 29.

${ }^{4}$ Floyd Greenleaf, The Seventh-day Adventist Church in Latin America and the Caribbean, 2 vols. (Berrien Springs, MI: Andrews University Press, 1992). and Floyd Greenleaf, A Land of Hope: The Growth of the Seventh-day Adventist Church in South America (Tatui, SP, Brazil: Casa Publicadora Brasileira, 2011). These are the most comprehensive works on the history of the Adventist Church in South America, describing the different evangelistic initiatives as it tells the story of the church. 
according to the original ethos ${ }^{5}$ of the Adventist movement in the United States. ${ }^{6}$

In terms of disciple making, ${ }^{7}$ five major groups of strategies of evangelization have been emphasized over the years by church leadership as part of the Adventist movement in Brazil: literature evangelism, public evangelism, radio and television evangelism, small group evangelism, and "integrated evangelism." 8 Although, from a historic viewpoint, these methods were introduced one at a time in the sequence mentioned above, these "ongoing methodological experiments" continue to be used. ${ }^{9}$

The rapid development of the Adventist Church in Brazil took place at the same time that the country was participating in the modernization of Latin America ${ }^{10}$ that resulted in the country achieving new economic, political, social, and religious status. ${ }^{11}$ Besides those contextual changes, George R. Knight points out that the Adventist

${ }^{5}$ Clifford Geertz's definition says that "a people's ethos is the tone, character, and quality of their life, its moral and aesthetic style and mood; it is the underlying attitude toward themselves and their world that life reflects." Clifford Geertz, The Interpretation of Cultures: Selected Essays (New York: Basic Books, 1973), 127.

${ }^{6}$ For a thorough study on the emergence of Adventism and limited description of its ethos, with heavy emphasis on the beliefs, see George R. Knight, William Miller and the Rise of Adventism (Nampa, ID: Pacific Press, 2010) and Denis Fortin, "Nineteenth-Century Evangelicalism and the Adventist Statements of Beliefs," Andrews University Seminary Studies 36, no. 1 (1998).

7"Evangelization" and "disciple making" will be used interchangeably in this proposal to refer to the overall process of becoming a true follower of Christ. Although, in literature and in conversations, one is commonly chosen over the other to emphasize a certain stage of that process due to the semantic baggage, it is being assumed that, theoretically, they refer to the same idea.

8"Integrated evangelism" was a South American Division initiative that aimed at combining the missionary efforts of the different denominational departments, institutions, and people.

${ }^{9}$ Alberto R. Timm, "Building a Growing Church: The South American Experience," Ministry, October 2008, 20-23.

${ }^{10}$ See Thomas E. Skidmore and Peter H. Smith, Modern Latin America, 5th ed. (New York: Oxford University Press, 2001) for an ample discussion on that transformation.

${ }^{11}$ Thomas E. Skidmore, Brazil: Five Centuries of Change, 2nd ed. (New York: Oxford University Press, 2010), 180-255. 
denomination as a whole is facing some serious challenges concerning its identity. ${ }^{12}$

Therefore, after also taking into consideration the major postmodern shift in philosophical understanding and globalization, ${ }^{13}$ the conclusion is that the Adventist Church in Brazil is on the verge of a convergence of external and internal influences at three different levels: global, national, and denominational.

Alan Hirsch suggests that "the twenty-first century is turning out to be a highly complex phenomenon ... [and] the church as we know it faces a very significant adaptive challenge."14 That is also true for the Adventist Church in Brazil. However very little academic research has been done to study or analyze the South American Adventist experience. ${ }^{15}$ The church continues to informally discuss what constitutes the fundamental factors, principles, and methods to fulfill Jesus' commission without seriously considering the previous experiences and contemporary realities from a missiological point of view. As George Knight points out, Adventism cannot avoid the discussion about being meaningful or being neutered. He suggests that Adventism

\footnotetext{
${ }^{12}$ Knight points out four specific challenges for the Adventist Church: (1) keeping its identity as an aging denomination; (2) keeping a "healthy middle-of-the-road balance" avoiding "acculturation to the larger community" and "segregation into a sectarian ghetto"; (3) keeping a healthy balance between congregationalism and overinstitutionalism; and (4) keeping its vision of itself as a people of prophecy. Knight, William Miller and the Rise of Adventism, 287-290.

${ }^{13}$ James Beckford offers a brief reflection on the relation between religious movements and globalization, even citing the Adventist Church, in his chapter in Robin Cohen and Shirin Rai, Global Social Movements (New York: Athlone Press, 2000).

${ }^{14}$ Alan Hirsch, The Forgotten Ways: Reactivating the Missional Church (Grand Rapids, MI: Brazos Press, 2006), 16.

${ }^{15}$ See, for example, Juan Carlos Viera-Rossano, "Seventh-day Adventists in Latin America: Their Beginnings, Their Growth, Their Challenges" (Fuller Theological Seminary, 1993). Viera-Rossano's work is both dated and limited. He dedicated only twelve pages of his dissertation to the Adventist Church in Brazil, the largest country of South America. His research reflects the debate about social-political theologies of the time and the Adventist perspective regarding the social responsibility.
} 
"became strong by proclaiming that it had a message for our time. And it is that message repackaged for the twenty-first century that will give Adventism strength both in the present and in the future." 16

\section{Research Questions}

1. What is the nature of a true Christian movement ethos and how does it foster church vitality?

2. How have the mission methods used by the Adventist Church in Brazil related to a true Christian movement ethos?

\section{Statement of Problem}

Very little academic research has been done to study or analyze the growth and development of the Adventist Church in Brazil. In terms of its mission methods, what is the Christian movement ethos that fostered this development in Brazil? How can it continue to foster Adventist church growth in Brazil in spite of contextual changes?

\section{Purpose Statement}

The purpose of this study is to analyze five major mission methods used by the Adventist Church in Brazil from 1895 to 2007 based on the characteristics of an Adventist missionary movement ethos in order draw lessons to face the contemporary contextual challenges.

\footnotetext{
${ }^{16}$ George R. Knight, The Apocalyptic Vision and the Neutering of Adventism (Hagerstown, MD: Review and Herald, 2008), 19.
} 


\section{Scope and Limitations}

The growth of the Adventist Church is verified in the general context of South America, but this research is delimited geographically to the country of Brazil. The time delimitation will include the arrival of the Adventist message between 1879 and 1880 as the beginning of the period and 2007 as the end. In 2008, the current South American Division administration was appointed. An accurate analysis of their current strategy of evangelization would be impossible as it is an ongoing process.

Limitations include the quality and quantity of information available, especially, about the early years of the Adventist work in Brazil. Only a few books have been written about that time, and the official denominational reports and correspondence are not extensive or complete. This research does not intend to be a historical account of the Adventist Church in Brazil in spite of including a historical survey that highlights key aspects of the employment of evangelization strategies. Selective snapshots of the historical developments in Brazil will inform this missiological analysis.

Finally, while this is not a statistical research project, it will rely on the official Adventist Church statistics. Statistical data will not be generated. Rather, available data will be analyzed to evaluate Adventist methodologies of evangelization in Brazil.

\section{Conceptual Framework}

Missiology has often been described as the interdisciplinary study of mission. Interdisciplinarity fosters the crossing of traditional boundaries of academic disciplines to borrow methods and insights and apply them toward a better understanding of a specific 
problem. ${ }^{17}$ This study will employ an approach that emphasizes holism rather than reductionism, acknowledging the advantages of such systems thinking for more complex problem solving. Other advantages of that approach include the possibility to avoid a stratigraphic analysis of missions in which different concepts and models from various disciplines are stacked together but remain self-contained. It also avoids mechanistic reductionism, which overemphasizes methods and disregards human needs and the sovereignty of God.

Gailyn van Rheenen has developed an interdisciplinary and interactive approach, called the Missional Helix,${ }^{18}$ intertwining theological reflection, cultural analysis, historical perspective, and strategy formation within the context of the practice of ministry. The Missional Helix starts with the Bible and its teaching about mission, includes a cultural analysis that brings awareness of the social construction of a certain reality, is informed by the historical development of missions in that specific context, and finishes with the strategic practice of ministry.

A helix is used as a metaphor in this case because it has been conceived as a spiral that returns time and time again to the same four stages in order to keep mission relevant to the actual context (see figure 1). Each step in the analysis is intended to build on what has already been discovered as a better understanding is developed about a specific

\footnotetext{
${ }^{17}$ A. Scott Moreau, Gary Corwin, and Gary B. McGee, Introducing World Mission: A Biblical, Historical, and Practical Survey (Grand Rapids, MI: Baker Academic, 2004), 73-74; Walter C. Kaiser, Mission in the Old Testament : Israel as a Light to the Nations (Grand Rapids, MI: Baker Books, 2000), 11-13; Alan R. Tippett, Introduction to Missiology (Pasadena, CA: William Carey Library, 1987), xiii-xv.

${ }^{18}$ Gailyn Van Rheenen, "From Theology to Practice: The Helix Metaphor," Monthly Missiological Reflection, no. 25 (2002), accessed April 23, 2010, http://www.missiology.org/mr-25-from-theology-topractice-the-helix-metaphor/
} 
context and God's will for acting in that context. Thus, according to van Rheenen "praxis impacts theology, which in turn shapes the practice of ministry." 19 Viggo Søgaard suggests that real learning and help comes from valuable research that can test strategies against experience and listen to those impacted by the service. ${ }^{20}$
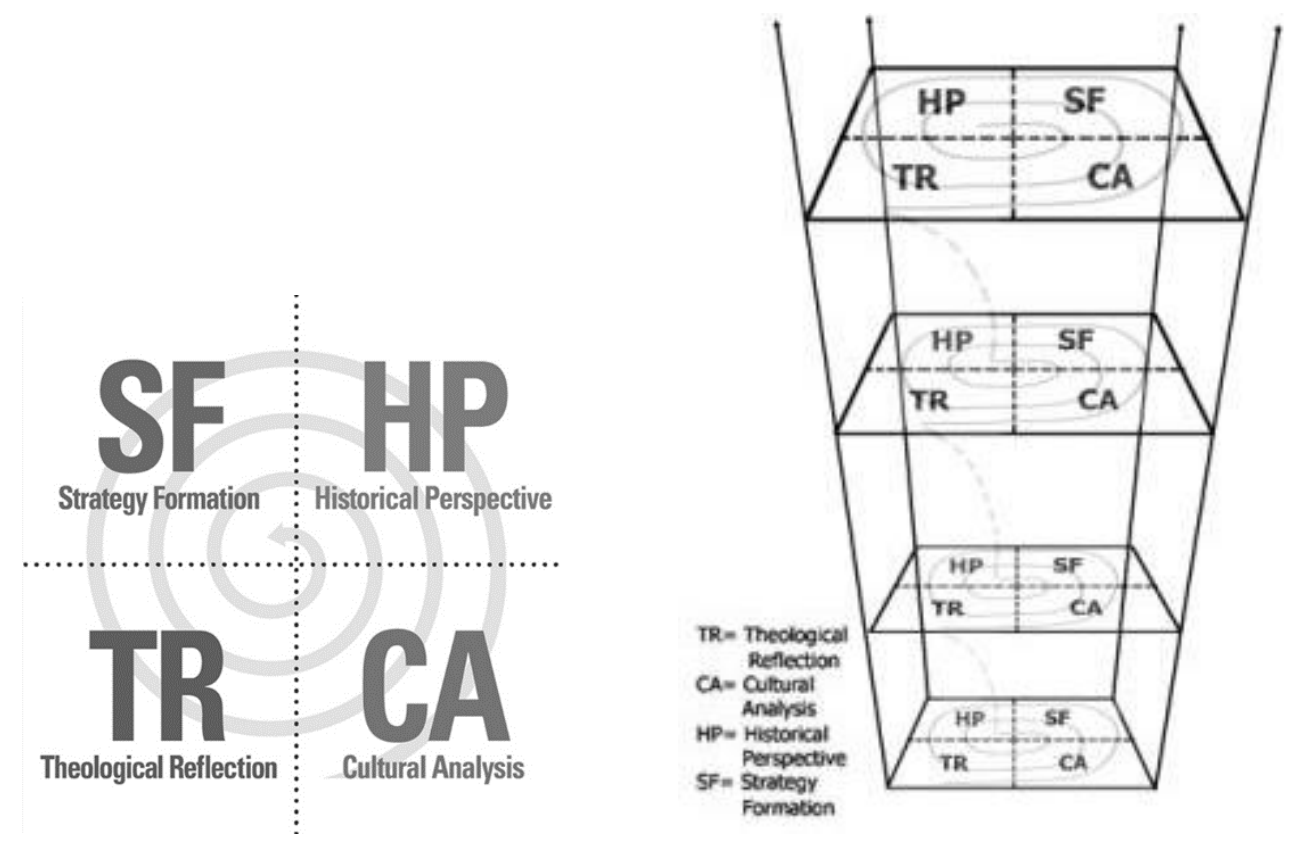

Figure 1. Van Rheenen's missional helix. Taken from Van Rheenen, "From Theology to Practice."

Following the missiological model and the awareness of the Missional Helix, this doctoral dissertation will adopt an interdisciplinary approach to undergird the research with a fabric woven from the threads of theology, the social sciences, and history. The xvi.

${ }^{19}$ Van Rheenen, "From Theology to Practice."

${ }^{20}$ Viggo Søgaard, Research in Church and Mission (Pasadena, CA: William Carey Library, 1996), 
large scope of time (over a century in this case) and geography (the expansive country of Brazil) certainly calls for an integration of disciplines to achieve a better understanding of the context and the issues that exist. A meaningful missiological synthesis would not be possible without such an approach.

History will contribute the linear developments of the Adventist Church and its evangelistic emphases, but it will also elucidate the major cultural shifts during the same period of time. Valuable suggestions from the social sciences will help describe the context in which mission took place both in the general society, and more specifically in the Adventist Church. Theology will provide the foundation for understanding Adventist mission and for evaluating methods of evangelization in the different phases of the church.

A foundational understanding for this study is the nature of Christianity and, consequently, of Adventism as a movement. Steve Addison defines it as follows:

In a general sense, movements are informal groupings of people and organizations pursuing a common cause. They are people with an agenda for change. Movements don't have members, but they do have participants. The goals of a movement can be furthered by organizations, but organizations are not the totality of a movement. A movement can have leading figures, but no one person or group controls a movement. ${ }^{21}$

In this case, Christianity would be defined as a movement with a mission that includes a message, a distinct view of truth; a communication of that message, in the context of relationships; and, a purpose of conversion to a new way of life that includes keeping the cycle going. In other words, Christianity is a missionary movement.

\footnotetext{
${ }^{21}$ Steve Addison, Movements That Change the World, rev. ed. (Smyrna, DE: Missional Press, 2009), 27.
} 
Also important in this research is the concept of ethos, commonly defined as the distinguishing character, sentiment, or fundamental values of a person, group, culture or movement. ${ }^{22}$ Majken Schultz's description of the relation between worldview and ethos is also helpful in defining these concepts. One should "distinguish between the cognitive world view that contains the ... mental image of reality, and the ethos, which comprises the . . . aesthetic and moral view of . . life in general." ${ }^{, 23}$ As part of the current critique of the overinstitutionalism of Christianity, ${ }^{24}$ and of Adventism, ${ }^{25}$ scholars have turned their attention to the study of the nature of movements and their ethos (also referred to as DNA or genius) in search for the core where "latent missional potencies"26 or the "life force and guiding mechanism of God's people"27 are built in and can be unleashed in contextualized strategies of evangelization.

Although there are other ways of evaluating disciple making strategies, especially based on numerical growth, the current major shifts mentioned in the background section require a deeper look into the intrinsic identity of movements which acknowledges that the Church is again facing a missionary reality that will necessitate the adoption of the

\footnotetext{
${ }^{22}$ Based on the definitions found in Merriam Webster, "ethos," http://www.merriam-webster.com/ dictionary/ethos and American Heritage Dictionary, "ethos," http://www.ahdictionary.com/word/ search.html?q=ethos

${ }^{23}$ Majken Schultz, On Studying Organizational Cultures: Diagnosis and Understanding, de Gruyter Studies in Organization (New York: W. de Gruyter, 1995), 89.

${ }^{24}$ Hirsch, The Forgotten Ways.

${ }^{25}$ George R. Knight, The Fat Lady and the Kingdom: Adventist Mission Confronts the Challenges of Institutionalism and Secularization (Boise, ID: Pacific Press, 1995).

${ }^{26}$ Hirsch, The Forgotten Ways, 15.

${ }^{27}$ Ibid., 18 .
} 
best concepts in cross-cultural mission methodology. ${ }^{28}$

One of the strengths of this study, therefore, is the fact that the analysis of the evangelization process will not be based exclusively on the effect of a movement's beliefs, but rather on a more holistic ethos. This is more realistic since, as Hirsch points out, "to be effective, movements, and the central ideas associated with them, must take root in the lives of their followers. If they do not, the movement simply will not ignite.”29 He further suggests that "to preserve the movement ethos of God's people, it is fundamental that the church keeps mission at the center of its self-understanding. Without mission there is no movement, and the community dies a death of the spirit long before it dies a physical death." 30

Another undergirding understanding is the well-known sociological contribution about the life cycle of organizations. ${ }^{31}$ They usually start as movements and the observation is that they gradually lose the type of ethos they had when they were started. ${ }^{32}$ Thus, the goal is to maintain or to reawaken, depending on the case, a movement ethos.

${ }^{28} \mathrm{Hirsch}$ argues that the distance between the majority of the people and the church is between $\mathrm{m} 1$ and $\mathrm{m} 3$, while traditional evangelistic practices are targeted to reach within shorter distance ( $\mathrm{m} 0-\mathrm{m} 1)$. Hirsch, The Forgotten Ways, 62.

${ }^{29}$ Ibid., 116.

${ }^{30}$ Ibid., 236.

${ }^{31}$ An informative research that relates the cycle of social movements and the ethos of Christianity is found in Jacobus Kok and Cornelius J. P. Niemandt, “(Re)Discovering a Missional-Incarnational Ethos," HTS Teologiese Studies/Theological Studies, 65, no. 1 (2009).

${ }^{32}$ Hirsch, The Forgotten Ways, 116. 
Alan Hirsch has received much attention for his proposal, in The Forgotten Ways, of a paradigm of "absolutely irreducible components" that are interrelated and form a Christian movement ethos. He suggests the following: (1) Jesus Is Lord, (2) Disciple Making, (3) Missional-Incarnational Impulse, (4) Apostolic Environment, (5) Organic Systems, and (6) Communitas, Not Community. He suggests that "these present us with a powerful paradigm grid with which we will be able to assess our current understandings and experiences of church and mission." 33

As even Alan Hirsch acknowledges in a footnote, one may feel the need to adapt his model for the analysis of a particular movement. Since there is a direct relation between a movement's beliefs and its ethos, in order to make this model more applicable to the Adventist movement, a part of this study is to work on that adaptation based on the unique Adventist beliefs.

\section{Methodology}

This interdisciplinary research will navigate the domains of theology, history, and sociology to accomplish its purpose. Most of its development is a result of researching library resources. For contextual information this work relies mostly on information found in historical sources. The collection of Revista Adventista, the Brazilian edition of the Adventist Review, which has been published since 1906, are essential to understand the missionary developments in Brazil. The timely publication of Floyd Greenleaf's $A$ Land of Hope: The Growth of the Seventh-day Adventist Church in South America, in

\footnotetext{
${ }^{33}$ Ibid., 24.
} 
2011, the most updated account of the history of the Adventist Church in South America, is another major source for historical information. ${ }^{34}$

Following the conceptual framework adopted, the first part of this research will be a biblico-historical overview of the character of Christian movements followed by a socio-religious systematization of the ethos of Christian movements. The third part will focus on the ethos of the Adventist movement in Brazil as a review of mission methods.

This research aims to give a contribution to Brazilian Adventist missiology, a very new area of study. These are some of the ways by which that objective should be accomplished: offering a model of interdisciplinary missiological research based on biblical theology, historical developments, and social sciences' insights; highlighting the ethos concept within the discussion about worldview as vital to move the discussion of Christianity beyond the cognitive level; learning lessons from the ways God has been at work in Brazil and Adventist mission methods employed that are helpful as the movement developed its strategies; suggesting a way of analyzing mission strategies based on their principles and not only their results, especially numeric ones; and challenging Adventists in Brazil and everywhere to live out Christianity as part of a missionary movement that is true to the Adventist identity.

\footnotetext{
${ }^{34}$ Greenleaf, A Land of Hope.
} 


\section{CHAPTER 2}

\section{THE BEGINNING OF CHRISTIANITY: THE RESHAPING OF A WAY OF BEING IN THIS WORLD}

Around two thousand years ago a world missionary movement began. At the periphery of Roman society Jewish men and women believed God was revealing Himself in history in a unique way. As a fulfillment of ancient prophecies, they believed that Jesus of Nazareth, a Jew, was the promised Messiah. ${ }^{1}$ Throughout His life, as He taught and ministered to people, Jesus gathered followers, made disciples, and sowed the seeds of what became Christianity.

This chapter will consider the beginnings of Christianity by describing the context in which it first developed and will then discuss Christ's mission, His message, His ministry, and His commission given to His followers. This section is primarily aimed at describing the nature of Christianity in its incipiency. Beginning with a description of the context of Jesus' times, especially the characteristics of Second-temple Judaism, this study considers Jesus Christ and His mission. A full discussion about the Greco-Roman context as well as Judaism itself is beyond the scope and focus of this section. However,

\footnotetext{
${ }^{1}$ This continuity between the prophecies in the Old Testament to the People of Israel and Jesus and His followers in the New Testament is not always emphasized. Stephen Neill, for example, points out that Christianity is one of the few religions "which is possible to trace to a definite beginning in time and the origin of which can be attributed to an identifiable founder." Stephen Neill, Christian Missions (Baltimore, MD: Penguin Books, 1964), 14.
} 
the researcher seeks to identify the major influences that helped shape Christianity and demonstrate the ingredients that shaped the new Christian movement.

Instead of a systematic approach to defining Christianity, this section will follow a more historiographical model with special focus on the dynamics found among its adherents. As N. T. Wright explains, the task at hand is primarily about studying human history, which has drama and actors, and "can only be fully understood when we learn to see the world through their eyes."2

\section{Background of Jesus' Times}

The focus of this section is the context at the birthplace of Christianity. The first part offers a general understanding of the historic dynamics that helped shape the Jewish way of life, followed by an outline of the main aspects of Second-temple Judaism in order to understand the religious Jewish identity during the time of Jesus. Some of the elements of the Jewish worldview that are described in this study include their controlling story, symbols, and hope. John the Baptist, as the precursor of Jesus Christ, appears at the end of this section.

\section{Historical Developments}

When Jesus was born, Palestine was under Roman rule. The complexity of the cultural influences in the region was far greater than one can assume. The Christian

\footnotetext{
${ }^{2}$ 'They believed, that is, in a god who was actively involved in their personal and corporate lives, who had intentions and purposes and was capable of carrying them out through both willing and uncomprehending human agents as well as (what we would call) 'natural forces." N. T. Wright, The New Testament and the People of God, Christian Origins and the Question of God (London: Society for Promoting Christian Knowledge, 1992), 118.
} 
movement began, as Cynthia White suggests, "in a Semitic world largely influenced by pan-Hellenic culture, education, and philosophy and ruled by Roman government and laws." 3 That unique cultural mix was the result of historical developments that had the objective of establishing "a far-reaching cultural unity" among the nations conquered by the Greek general, Alexander. John William Drane points out that "Alexander was a fanatic for his own native culture, and was genuinely convinced that civilization had reached its ultimate goal with the Greek way of life." ${ }^{4}$ Palestine was conquered by Alexander the Great in 332 BC and even though Jews were given considerable cultural and religious freedom, by the beginning of the second century, strong Hellenistic influence could be seen. ${ }^{5}$ Also influential in the formation of the identity of first-century Jewish life was the Maccabaean crisis.

It was, first, the backward reference-point for continued speculation about Israel's eventual deliverance from pagan rule. ... But the Maccabaean crisis was also, second, the cause of some of the divisions within Judaism. Dissatisfaction with its outcome was the reason for the rise and agenda of at least some of Judaism's different parties. $^{6}$

${ }^{3}$ Cynthia White, The Emergence of Christianity: Classical Traditions in Contemporary Perspective (Minneapolis, MN: Fortress Press, 2011), 1.

${ }^{4}$ John William Drane, Introducing the New Testament, Completely rev. and updated. ed. (Oxford: Lion Publishing, 2000), 17.

${ }^{5}$ Matt Stefon, Judaism: History, Belief, and Practice, The Britannica Guide to Religion (New York: Rosen Educational Services, 2012), 28. The predominant Greek aspect of the culture, which varied from place to place, was one of the keys to the reuniting and conquering of territories under Octavian, a Roman emperor (63 BC-AD 14) in 31 BC. Drane, 17.

${ }^{6}$ Wright, The New Testament and the People of God, 167. "Within Judaism of the time of Christ one could find different trends, schools, and sects. All these groups had their origins in the years following the Maccabean Revolt, and their actual membership was probably quite small, though most people would look to one of them for leadership, in much the same way as people nowadays might regularly vote for a particular political party, without joining it in a formal way as members," Drane, Introducing the New Testament, 35. For detailed studies, see Armin Lange, Diethard Römheld, and Matthias Weigold, Judaism and Crisis: Crisis as a Catalyst in Jewish Cultural History (Schriften des institutum Judaicum delitzschianum) (Oakville, CT: Vandenhoeck \& Ruprecht, 2011). 
Finally, the dominant power of Greece was replaced by the Romans. The Jews continued to be a group without autonomy and subject to the ruling power's influence and culture. Herod the Great, who had risen as the Roman client king of Judea decided to maintain order throughout his territory at all costs and to rebuild the nation.

If these political developments did not seem to offer much hope for the long term, Greek philosophers did not seem to have the answers either. Those philosophers had not been able to offer valid alternatives to the "moral and spiritual vacuum." In the religious realm, the diversity of ideas competed to answer people's anxieties that seemed to define a great deal of the Jewish identity around the first century. "There was no shortage of religious ideas that could fill the gap, and people whose confidence in their inherited spiritualities had been eroded were ready to try anything that might give them new hope in an uncertain world."

The different views within the Jewish community were also identified in geographic terms, since the Diaspora groups were continually exposed to local influences and challenged in the maintenance of their identity in a foreign environment. However, Wright points out that cultural, social, and religious differences could also be noticed even between closely connected locations such as Galilee and Jerusalem. There were considerable differences between cultural, social, and religious needs and viewpoints of the Jews living in the Jerusalem area on the one hand and Jews in Galilee on the other. In that context, "the Torah assumed new importance in border territory. ... It acquired some of the functions and attributes of the Temple itself. And the features of Torah which

\footnotetext{
${ }^{7}$ Drane, Introducing the New Testament, 19.
} 
loomed largest were those which functioned specifically and obviously as cultural, social and religious boundary-markers, i.e. Sabbath, food-laws and circumcision.",

In spite of all the diversity and narrow vision for the future, "the Jews of Palestine never lost their firm determination to resist religious compromise and, if possible, to preserve their own rights to political self-determination." "At that time, the polytheistic Greco-Roman world contained innumerable gods and diverse religions, all implicated to some degree in the political and cultural structures of native populations."10

The hope of Israel, and of most special-interest groups within Israel, was not for post mortem disembodied bliss, but for a national liberation that would fulfill the expectations aroused by the memory, and regular celebration, of the exodus, and, nearer at hand, of the Maccabaean victory. Hope focused on the coming of the kingdom of Israel's god. ${ }^{11}$

Therefore, the political and cultural context of Palestinians at the time of Jesus had been strongly influenced by the historical conquests and dominance of both Greeks and Romans. A lack of independence and autonomy evidenced even more the unique Jewish identity and pushed people to be even more hopeful for God's promised kingdom.

\section{Jewish Worldview}

The context in which Christianity arose had developed over time. "The history of Israel and all their prospects were intertwined with their religion; so that it may be said

\footnotetext{
${ }^{8}$ Wright, The New Testament and the People of God, 168.

${ }^{9}$ Drane, Introducing the New Testament, 32.

${ }^{10}$ White, The Emergence of Christianity, 1.

${ }^{11}$ Wright, The New Testament and the People of God, 169-70.
} 
that without their religion they had no history, and without their history no religion." 12 More specifically, the way Jews lived during the time of Jesus was shaped by Secondtemple Judaism.

In order to understand Judaism it is important to understand the Jewish worldview values during the time of Jesus. In Jewish society, religion was at the center of their lives and largely defined their worldview. "Judaism arose out of the religion of Israel. It came through lawgivers, priests, and prophets and was the outgrowth of centuries of development. ... The tie which held the Jews together was religious and the religion was Judaism."13

The Jewish identity did not conceive of religion as an option but as the defining center of their worldview. That shared worldview was responsible for their unity in the face of so many differences. Wright, one of the most important New Testament scholars, identifies the core of Judaism at the time of Jesus.

The main feature of first-century Judaism, within Palestine at least, was neither a static sense of a religion to which one adhered, nor a private sphere of religion into which one escaped, but a total worldview, embracing all aspects of reality, and coming to sharp focus in a sense of longing and expectation, of recognition that the present state of affairs had not yet (to put it mildly) seen the full realization of the purposes of the covenant God for his people. ${ }^{14}$

Besides the fact that religion occupied the center of and defined the Jewish identity, their worldview did not have a dualistic view that considered belief and practice

\footnotetext{
${ }^{12}$ Alfred Edersheim, The Life and Times of Jesus the Messiah, vol. 1 (Bellingham, WA: Logos Bible Software, 1896), 4. 1975), 1:10.

${ }^{13}$ Kenneth Scott Latourette, A History of Christianity, rev. ed., 2 vols. (New York: Harper \& Row,

${ }^{14}$ Wright, The New Testament and the People of God, 148-49.
} 
as two distinct dimensions. Jews were essentially concerned with what one ought to do (rituals and festivals became especially significant in order to perpetuate the story and symbols). More specifically, "Jews do not characteristically describe the nature of Judaism in terms of 'beliefs'. ... Judaism characteristically thinks of itself as a way, a halakah, a life-path, a way of being-in-the-world."15

Prophets had been not only announcing the Word of God but also registering it in written form, which helped to assure that Scriptures guided the lives of those who followed God. Different parts of Scripture impacted different aspects of Jewish life and helped shape their worldview. Latourette underlines the role of the Law and the Prophets concerning the regulation of diet, the observance of days, and circumcision. An average Jew believed that God "gave him His law to control his conduct. That law had to do both with what are usually called morals and with ritual. It was briefly summarized in the Ten Commandments, but it had much more elaborate formulations." ${ }^{16}$ Wright suggests that the psalter would have been especially influential in shaping "the mental furniture of the average Jew." 17 Thus, the centrality of Scriptures is probably the most visible thread in the tapestry of the first-century Jewish worldview as it provided the overarching story, teachings, and prophecy.

\footnotetext{
15“'Thus we may grant the point that we do not find, certainly in the first century, non-Christian Jewish works which have the form we now associate with a work of 'theology', that is, an abstract discussion of a point, or system, of belief; but this should in no way prevent us from producing, ourselves, a description and analysis of basic and consequent beliefs, not least now that we have set out the context of symbol, praxis and story which show how these beliefs come to expression." Wright, The New Testament and the People of God, 245-46.

${ }^{16}$ Latourette, A History of Christianity, 1:12.

${ }^{17}$ Wright, 241. "Scripture as the story, creating the context for the present, and scripture as Torah, creating the ethic for the present, both undergirded scripture as Prophecy, pointing forward to the way in which the story would reach its climax —-for those who were faithful to Torah.” Ibid., 242.
} 
The future orientation of the Jewish faith became especially detectable just prior to the birth of Christ through the wide-spread apocalyptic literature and the renovated belief in the coming of the Messiah. These writings focused on eschatological events and revealed important characteristics of the Jewish understanding about history, such as (1) the belief that God was in control and intervenes in human affairs, (2) that there was a predominant linear dimension to history, (3) that there would be a climax to the current developments, and (4) that God must ultimately triumph. The concrete reality that captured that vision was the expected Messiah. "Various views of the Messiah were held, but all agreed that he was the 'anointed' - for that is what the word meant $—$ a king who was to reign under divine commission." ${ }^{\prime 18}$

\section{The People of God: The Controlling Story}

One of the most important aspects of the Jewish worldview was the understanding that they were the people of God. A sense of a special connection with a god is very common in anthropology. Such studies have demonstrated that most groups of people have some type of belief in a superior being. The differences are in their relationship with that being, which often needed to be appeased. Gods are often connected with a tribe, a territory, and a people. ${ }^{19}$ That was the case with the Jews, but there was more. The spiritual worldview of the Jewish people was characterized by their belief and claim to be the people of God (e.g., Ruth 1:16).

\footnotetext{
${ }^{18}$ Latourette, A History of Christianity, 1:13.

${ }^{19}$ Neill, Christian Missions, 13, 14.
} 
That sense of being the people of God transcended the group of Jews of the time of Jesus. "The foundation story of Judaism, to which all other stories were subsidiary, was of course the story in the Bible. Israel had told this story, one way or another, pretty much as long as she had been Israel." 20 The closing of that story, however, was dependent on Israel's keeping of its covenant with God.

Israel's stories are therefore to be understood, at their deepest level, not merely as moralistic tales or pious legends designed to glorify heroes and heroines of old. They embody, in a rich variety of ways, the worldview which in its most basic form remains anchored to the historical story of the world and Israel as a whole. The creator has called Israel to be his people. ${ }^{21}$

The concept of the people of God is defined in the Old Testament by understanding election and covenant (Micah 4:5; Isa 49:6; Isa 2:3; Zech 8:23). “All Jews believe that they belonged to a special people, descended from Abraham. All Jewish boys were circumcised on the eighth day after their birth as a sign of this covenant, and all Jews sought to keep the Law. This was part of a sacred covenant between God and his people." 22 "The condition of the covenant was obedience; the promise was that "you shall be My own possession out of all the peoples.' The promise involves a God-people and people-God relationship that is the center of the OT." 23

Under the dominance of the Greek and Roman empires with little hope given by philosophers, the fact of the Diaspora, and a variety of religious understandings, the

\footnotetext{
${ }^{20}$ Wright, The New Testament and the People of God, 216.

${ }^{21}$ Ibid., 223.

${ }^{22}$ Jonathan Hill, Christianity: How a Despised Sect of a Minority Religion Came to Dominate the Roman Empire (Minneapolis, MN: Fortress Press, 2011), 8.

${ }^{23}$ Samuel Tang, "People of God," Holman Illustrated Bible Dictionary, ed. Charles W. Draper, C. Brand, and Archie England (Nashville, TN: Holman Bible Publishers, 2003), 1273.
} 
golden thread of Jewish religious identity as the people of God was especially influential in their way of living. "This fiercely independent posture was largely the result of their belief that they had been specially chosen by God to rule the world under the leadership of God's promised deliverer, whom they called the 'Messiah'.,24

Christianity arose in connection with this long heritage that included the people of Israel as described in the Old Testament. Even though the self-understanding as a people of God is part of Second-temple Judaism, it was not restricted to that period. It was an important motif in the Old Testament and continues as a thread through different periods of the people of Israel until it reaches the time of Jesus.

\section{Temple, Land, and Torah: Their Symbols}

In many practical ways, the Jewish worldview found expression in three key symbols: the temple, the land, and the Torah. ${ }^{25}$ "At the heart of the Jewish religion was the Temple, which had originally been built by King Solomon in Jerusalem centuries before and had been recently restored and rebuilt by Herod the Great." ${ }^{26}$ Besides being the center of Jewish religious life and daily rituals, the temple and the presence of God served "as a framework for his spiritual elevation and purification." 27

${ }^{24}$ Drane, Introducing the New Testament, 32.

${ }^{25}$ Wright, The New Testament and the People of God, 224.

${ }^{26}$ Hill, Christianity: How a Despised Sect of a Minority Religion Came to Dominate the Roman Empire, 9. Cited in Wright "Local synagogues and schools of Torah in other parts of Palestine, and in the Diaspora, in no way replaced it, but gained their significance from their implicit relation to it." Wright, The New Testament and the People of God, 224.

27، The Temple, its vessels and even the high priest's vestments were depicted as representing the entire universe and the heavenly hosts. ... With the destruction of the Temple the image of the universe 
The land was the means of subsistence.

It was the source of bread and wine, the place to graze sheep and goats, grow olives and figs. It was the place where, and the means through which, YHWH gave to his covenant people the blessings he had promised them, which were all summed up in

the many-sided and evocative word shalom, peace. It was the new Eden, the garden of YHWH, the home of the true humanity. ${ }^{28}$

And the Torah united God and His people by telling the story of God's creation, election, redemption, God's promises about His blessings for the present and future, and the expectations about their covenant. The Torah also helped define the Jewish way of life, especially in the Diaspora, by teaching and exhorting Jews to put into practice values that set them apart from their pagan neighbors such as circumcision, the keeping of the Sabbath, and the purity laws. These values and practices helped make their worldview a matter of daily reality.

By the beginning of Christianity, the number of Jews outside Palestine was larger than the number in it. The distance from the Temple influenced many expressions of Judaism, thus, the importance of local synagogues. 29 "In them the Law and the Prophets were read and expounded. Through them and the instruction given in them Judaism was perpetuated. Schools were associated with the synagogues and in them the Scriptures and the unwritten law were taught."30

was rendered defective, the established framework of the nation was undermined and a wall of steel formed a barrier between Israel and its heavenly Father." Wright, The New Testament and the People of God, 224.

${ }^{28}$ Wright, The New Testament and the People of God, 226.

${ }^{29}$ Hill, Christianity, 11. "The synagogue had a central part (not only in 'religion', but also) in the total life of a local community, and words heard often in that context, especially if they were understood to be promising liberation, would be cherished lovingly." Wright, The New Testament, 241.

${ }^{30}$ Latourette, A History of Christianity, 1:14. 


\section{Missionary Zeal: Their Hope}

Another element of Judaism at the beginning of Christianity was its missionary

zeal. According to Joachim Jeremias, such zeal had not always been present in the Jewish mentality.

During its early history Israel was not a missionary people. The beginnings of missionary activity are to be found in the post-exilic period, and are closely connected with the rise and development of the Diaspora; but only after the Maccabaean period can the age of missions be strictly said to have begun. This was a wholly new phenomenon: Judaism was the first great missionary religion to make its appearance in the Mediterranean world. ${ }^{31}$

Consequently, many people who had contact with the Jewish communities were impacted by Jewish values and beliefs.

The Jews were profoundly convinced that theirs was the only true religion and that it would sometime become the faith of all mankind. They probably had few professional missionaries whose assignment it was to win the Gentiles, but in their intercourse with the non-Jews - the 'Gentiles' - many Jews sought to bring the latter to their faith. ${ }^{32}$

Besides the general religious longing and the self-understanding as the people of

God with a message of revealed truth, Jeremias lists three evidences of Jewish missionary zeal. First, a great part of the literature in Hellenistic Judaism is "of an apologetic nature, specially designed to appeal to the educated classes, and intended to promote the success of the mission by removing the objections to Judaism and its religion." Second, Judaism was contextualized as Gentiles were introduced to it. "The proclamation of Judaism was simplified by the relegation of the ritual descriptions to the background and by emphasis

${ }^{31}$ Joachim Jeremias, Jesus' Promise to the Nations (Naperville, IL: Alec R. Allenson, 1958), 11.

32“"Their synagogue services were open to all, whether Jew or Gentile. Many Gentiles were attracted to Judaism. Some of them partly adopted Judaism but did not become full members of the Jewish community. . . Others went the whole way and became full proselytes." Latourette, A History of Christianity, 16. See also David J. Bosch, Transforming Mission: Paradigm Shifts in Theology of Mission (Maryknoll, NY: Orbis, 1991), 25. 
on the moral code." And third, Christians found proselytes and godfearers in many places. "The Diaspora constituted the primary channel of the mission ... whereas in the homeland there was to some extend a tendency to adopt a passive attitude of waiting for 
the Gentiles to come forward (hence the term 'proselytos' meaning 'he who comes forward')." 33

Judaism became somewhat "popular" during this time for many reasons: (1) the large numbers of Jews who lived in the main cities of the empire; (2) the keeping of the Jewish identity by those in the Diaspora; (3) a welcoming attitude, since they "were usually more than happy for others to join them;" (4) Judaism, despite some mysterious understandings, was simple for Gentiles to understand; (5) outsiders could see its practical relevance in the everyday life of their Jewish friends; (6) people had access to the Jewish scriptures in their own Greek language; and (7) "Jewish emphasis on rigorous standards of personal and social morality found a warm reception among many thinking Greeks and Romans, who were dissatisfied with the permissiveness of their own culture." 34

The Jewish worldview as shaped by Second-temple Judaism was the result of a matrix of influences and was developed in connection with the history and religion of Israel. Religion did not belong in a private sphere of life but defined the lenses through which Jews perceived actual life. Judaism, therefore, was more concerned with praxis, was much more a way of living than a set of theoretical articulations. Since the Scripture was central to Judaism, its story explained the past, created the ethic for the present, and pointed forward to the climax of history. The understanding that Jews were the people of

\footnotetext{
${ }^{33}$ Hillel (circa AD 20) "was certainly favourable to missions; one of his sayings was, 'love mankind and bring them to the Law. The immediate future was destined to follow Hillel's theology. But the most obvious defect of the Jewish mission lay in its insistence on the inseparable connexion between religion and national custom." Jeremias, Jesus' Promise to the Nations, 13-17.

${ }^{34}$ Drane, Introducing the New Testament, 25.
} 
God undergirded their worldview. Their temple, land, and Torah were the major symbols of their identity. And their missionary zeal concentrated their sense of purpose and urgency as instruments among all the peoples of the earth. As Wright summarizes it, "There is one creator god, who has chosen Israel to be his people, giving her his Torah and establishing her in his holy land. He will act for her and through her to re-establish his judgment and justice, his wisdom and his shalom, throughout the world." ${ }^{35}$

\section{John the Baptist}

Prophets also reflected the Jewish worldview and its major elementsmonotheism, covenant, and eschatology — and were another connection with the religion of Israel. They were the spokesmen of YHWH to His people in the context of the unfolding events of the last days including God's judgment. Their involvement included not only the communication of God's revelation and the foretelling of the future but their belief that God was the ruler of all the earth was stressed along with their rebuking of wickedness. ${ }^{36}$ "Prophets had often condemned the people for their disobedience to the moral and spiritual standards God required of them, and declared that though they were still God's people, they could expect only judgment for their failure to live up to these expectations." ${ }^{37}$

As explained earlier, the Jewish historical understanding pointed to a climax with the coming of the Messiah. The growing amount of apocalyptic literature at the time

\footnotetext{
${ }^{35}$ Wright, The New Testament and the People of God, 279.

${ }^{36}$ Latourette, A History of Christianity, 1:12.

${ }^{37}$ Drane, Introducing the New Testament, 53.
} 
indicated that the people believed that something was about to happen. George Ladd points out that during the intertestamental period instead of the prophetic voice there were two streams of religious life: scribal religion that emphasized the strict obedience to the written Law and the apocalyptists who added apocalyptic writings to the interpretation of the will of God. "There is also no evidence that their writings created popular eschatological movements among the people, stirring them up to expect the imminent intervention of God to bring his Kingdom.” One such group, the Qumranians, who had a strong apocalyptic orientation, withdrew in the desert and did not think to have a mission toward the larger group. ${ }^{38}$

In the context of the beginning of Christianity, John the Baptist and his ministry are especially significant. Although he began his ministry during a time of high apocalyptic expectations, his prophetic mission may have been a surprise ${ }^{39}$ besides having a different emphasis. "Apocalyptic literature places little emphasis on conversion. Israel was the people of God because they alone of all nations had received the Law. . . . John's baptism rejected all ideas of nationalistic or legal righteousness and required a moral-religious turning to God. He refused to assume a righteous people." ${ }^{\prime 40}$

Sometimes ignored in the history of Christianity, John the Baptist preceded Jesus' mission in many ways, although their ministry should not be confounded. His was a 35.

${ }^{38}$ George Eldon Ladd, A Theology of the New Testament (Grand Rapids, MI: Eerdmans, 1974), 34-

39،"Many had been looking for a sign from God, but they hadn't expected it to look like this. Many had wanted a Messiah to lead them against the Romans, but they weren't anticipating a prophet telling them to repent." Tom Wright, Mark for Everyone (London: Society for Promoting Christian Knowledge, 2004), 1.

${ }^{40}$ Ladd, A Theology of the New Testament, 39, (italics added). 
preparation for what was to come. After a period with little or no prophetic voice, ${ }^{41}$ John the Baptist burst upon the national scene with an important announcement: "The kingdom of heaven has come near (Matt 3:2).” He began to preach about an imminent happening as a prophet. Much of his ministry was about retelling the stories they knew so well. ${ }^{42}$ His message about the manifestations of God gained favor with the people, gathered large audiences (Mark 1:5), exhorted them to repent, gave hope, and made disciples. His ministry proclaimed a baptism with the Holy Spirit and with fire (Mark 1:8, 3:11), but primarily introduced Palestine to the mission of the "Coming One" (Matt 3:11), the expected Messiah.

John "did not see himself as a messianic deliverer appointed by God to get rid of the political and social injustices of the time, but as 'a messenger,' 'a voice' sent to bring the good news that the Messiah was about to come, and the nature of God's kingdom would soon be made plain (Mark 1:2-3)." ${ }^{43}$ This soon coming would be significant because of its offer of salvation by taking away the sins of the world. Flavius Josephus, the Jewish historian from the first century, points out that John the Baptist "commanded

\footnotetext{
41، According to one strand of Jewish belief, prophecy had ceased with Malachi, whose book came to a close with the prediction of the return of Elijah to herald the Day of the Lord. To present John as a prophet was, therefore, for those who subscribed to this view of prophecy, a daring and far-reaching claim, made the more striking when the pericope begins with a quotation of Malachi's eschatological prediction, and still further when John is described in terms used in the OT to mark out the distinctive characteristics of Elijah (see on v. 6). John is thus even 'more than a prophet' (Mt. 11:9). His coming marks the beginning of the end.” R. T. France, The Gospel of Mark: A Commentary on the Greek Text, New International Greek Testament Commentary (Grand Rapids, MI; Carlisle: W. B. Eerdmans, 2002), 62.

${ }^{42}$ John the Baptist's message was about the exodus. "But instead of simply hearing the words and remembering the story, John was turning it into a drama, a play, and telling his hearers that they were the cast. They were to come through the water and be free. They were to leave behind 'Egypt' - the world of sin in which they were living, the world of rebelling against the living God" Tom Wright, Mark for Everyone (London: Society for Promoting Christian Knowledge, 2004), 2.

${ }^{43}$ Drane, Introducing the New Testament, 53.
} 
the Jews to exercise virtue, both as to righteousness toward one another, and piety towards God, and so to come to baptism." And he adds that "many were very greatly moved by hearing his words. ${ }^{44}$ As Drane concludes, John the Baptist called the people to meet the person "who was to establish God's new way of being." ${ }^{45}$ It is important to emphasize, as does James A. Brooks, that “John's message concerned not only a way of life and a rite symbolizing that way of life but a person." 46

The context at the beginning of Christianity is characterized by the Jewish way with a worldview that was defined by their religion, which was essentially concerned with what one ought to do in relation to God. This sense of purpose was also shaped by a future orientation that pointed toward a salvation climax and included the people's duty toward other nations.

\section{Jesus Christ and His Mission}

Christianity, as the word suggests, is directly linked to Jesus Christ and His mission. The person of Jesus, His teachings, and His ministry are the focus of this section. By considering these aspects, this study aims at presenting a core understanding of who Jesus was, what He did, and what He envisioned for His followers. When coupled with the previous description about the Jewish context, one will be able to better

\footnotetext{
${ }^{44}$ Flavius Josephus, “Antiquities of the Jews,” accessed July 17, 2013, http://www.biblestudytools .com/history/flavius-josephus/antiquities-jews/, 18.5.2.

${ }^{45}$ Drane, Introducing the New Testament, 53.

${ }^{46}$ James A. Brooks, Mark, The New American Commentary (Nashville, TN: Broadman \& Holman, 1991), 41.
} 
comprehend the initial development of Christianity and the character of what was going

to be a worldwide movement.

\section{Jesus Christ}

By assuming the historicity and the accuracy of the Bible accounts, ${ }^{47}$ it can be stated that "Jesus Christ stands at the head of all Christian tradition." 48 Even though a group of modern scholars have insisted in crediting the founding of Christianity to others, ${ }^{49}$ Jeremias points out that "no one in the ancient church, no one in the church of the Reformation period, and of the two succeeding centuries thought of asking that question.",50

Jesus was born during the time of Augustus, the first Roman emperor (27 BCE-14 CE) and of Herod the Great, King of the Jews (40-4 BCE). ${ }^{51}$ He was born a Jew in Bethlehem, lived in Nazareth, and traveled around Palestine during His ministry. Raised

\footnotetext{
${ }^{47}$ The Gospels, the four accounts about the life of Jesus found in the Bible, are the richest source of information about him. Although the historicity of Jesus has been questioned by critical scholars, there is general agreement about the major points of his life. This researcher believes in the historicity and accuracy of the records as found in the Bible.

${ }^{48}$ John Mark Terry, Ebbie C. Smith, and Justice Anderson, Missiology: An Introduction to the Foundations, History, and Strategies of World Missions (Nashville, TN: Broadman \& Holman Publishers, 1998), 63.

${ }^{49}$ This becomes clear, for example, by the discussions of N. T. Wright, What Saint Paul Really Said: Was Paul of Tarsus the Real Founder of Christianity? (Grand Rapids, MI: W. B. Eerdmans, 1997), and statements such as the introduction of Jonathan Hill's Christianity: "Christianity was founded by a group of fishermen and peasants from Galilee." Hill, Christianity, 7.

${ }^{50}$ Joachim Jeremias, Jesus and the Message of the New Testament, Fortress Classics in Biblical Studies (Minneapolis, MN: Fortress Press, 2002), 1.

${ }^{51}$ White, The Emergence of Christianity, 31. Jesus grew up exposed to Roman and Hellenistic influences that shaped his surroundings. The gospels make reference to familiarity with Roman military practices (Mark 5:9 and Matt 5:41), the reign of Caesar Augustus and his census (Luke 2:1), Herod's conspiration, etc.
} 
in an ordinary working-class family, He spoke Aramaic, and lived a little over 30 years. Jesus grew up in a faithful but poor Jewish family ${ }^{52}$ "in the midst of a people actively engaged, both by the spoken and the written word, in a Gentile mission, whose impelling motive was a profound sense of their obligation to glorify their God in the Gentile world." ${ }^{53}$

When Jesus was around 30 years old, he met John the Baptist, was baptized by him, and began an itinerant ministry. What made Jesus' identity especially intriguing, however, was the fact that some Jews recognized him as the promised Messiah. "God at last answers the hopes that the prophets had planted, nurtured, and stirred in his people. However, the fulfillment of their hopes comes in an unexpected way. Jesus did not come as a conquering king ready to take over Rome." ${ }^{, 54}$

The emphases in the ministry of Jesus can be summarized as teaching, healing, and preaching. Even though Jesus related to people from different social statuses, the destitute received special attention. Jesus' involvement with the people went beyond a formal relationship as He gathered followers and intentionally made disciples. Different people responded favorably to Jesus' ministry. Among His close group of disciples, for example, were fishermen, a former tax-collector, and several women.

Jesus claimed to be the Son of God and the Son of man, and after a little more than three years of public ministry His life was cut short by execution on a Roman cross.

\footnotetext{
52،"He was born in a stable to a young peasant girl, dedicated through the sacrifice of two young pigeons because His parents couldn't afford a lamb, and raised as a carpenter in Nazareth, a town that is never mentioned in the Old Testament." Timothy C. Tennent, Invitation to World Missions: A Trinitarian Missiology for the Twenty-First Century (Grand Rapids, MI: Kregel, 2010), 396.

${ }^{53}$ Jeremias, Jesus' Promise to the Nations, 17.

${ }^{54}$ Moreau, Corwin, and McGee, Introducing World Mission, 40.
} 
Even though Jesus did not meet the nation's expectation, His death did not stop His followers from believing that $\mathrm{He}$ was the promised Messiah because $\mathrm{He}$ was resurrected on the third day and ascended into heaven.

\section{Jesus' Message}

One of the primary and distinctive aspects of Jesus's life was His message, which is clearly evident in His preaching and teaching. Drane, for example, highlights the fact that, despite the similarities with wandering teachers of the time, Jesus, in a short time, "delivered a message that was to exert a crucial influence not only on his own people, but on the subsequent course of world history." ${ }^{, 55}$

After Jesus performed His first miracle at the wedding at Cana (John 2:1-12), He began to preach about God's kingdom throughout Galilee. The Gospel writers list more than a hundred references to the kingdom in Jesus' teaching. ${ }^{56}$ As Ladd points out, "modern scholarship is quite unanimous in the opinion that the Kingdom of God was the central message of Jesus" 57 "The announcement of the Kingdom of God deserves a special place, for the hope of the kingdom occupies a central place in OT eschatology.... In Jesus' teaching the NT gives to the kingdom an even more important role." ${ }^{n 5}$

\footnotetext{
${ }^{55}$ Drane, Introducing the New Testament, 10-12.

${ }^{56}$ Gerhard F. Hasel, "Divine Judgment," in Handbook of Seventh-day Adventist Theology, ed. Raoul Dederen (Hagerstown, MD: Review and Herald, 2001), 900.

${ }^{57}$ Ladd, A Theology of the New Testament, 57. In the subsequent pages Ladd gives a brief historical overview of the different positions on the meaning of the kingdom of God.

${ }^{58}$ Hasel, "Divine Judgment," 899-900. The understanding about God's kingdom demanded a familiar concept from the Hebrew Bible a king: God the creator and ruler of the whole world (Isa 6:5, 52:7; 2 Chr 9:8; Zeph 3:15; Isa 24:23; Zech 14:9; Dan 7), instead of a local nationalistic concept common in the Ancient Near Eastern and Mediterranean world. Jonathan Knight, Christian Origins (New York: T \& T Clark, 2008), 99. "If Yahweh is the One who rules over the earth and the nations (Ps. 29; 47; 74; 89; 93; 96-99), His eternal kingdom is also expected (Dan. 2:34, 44), and it will be established on Yahweh's great
} 
The concepts of the gospel and the kingdom are related in Matt 24:14 and Mark 1:14-15 and set the context for other verses in the Gospels (Matt 4:17; Luke 4:43; Matt 11:5; 26:13; Mark 8:35; 10:29; 13:10; 14:9; Luke 4:18; 7:22). Within the broad teaching of Jesus about the kingdom of God, Harvey points out three major paradoxical aspects: "(1) it is both 'now' and 'not yet'; (2) it is both 'good news' and 'bad news'; and (3) it is both minuscule and mighty." ${ }^{\prime 59}$ The present ("now") reality of God's kingdom is introduced by Jesus (Luke 11; 20; Matt 12:28; Luke 17:20-21) when at His incarnation He invaded the domain of Satan and through His life, death, and resurrection, created a "present spiritual realm in which the blessings of God's reign are already experienced." 60 Even before Satan's final destruction, people could be delivered from his power. ${ }^{61}$

But Jesus also teaches about a future reality ("not yet") of the kingdom to which all should look forward to (Matt 16:28; Mark 9:1; Luke 9:27; Matt 8:11-12; 26:29; Mark 14:25; Luke 13:28-29; 22:18, 28-30). Matthew registers 32 references made by Jesus about the kingdom of heaven and in the gospel of John one finds Jesus' revealing words before Pilate: "My kingship is not of this world" (John 18:36). ${ }^{62}$

day (Zech. 14:9; Obadiah 15, 21; Isa. 2:12-21; 24:21-23). Long before the Davidic monarchy, the kingdom of God was celebrated in song (Ex. 15:1-18; Num. 23:21, 22; Deut. 33:5).” Hasel, "Divine Judgment," 899-900.

${ }^{59}$ John D. Harvey, "Mission in Jesus' Teaching," in Mission in the New Testament: An Evangelical Approach, ed. William J. Larkin and Joel F. Williams, American Society of Missiology Series (Maryknoll, NY: Orbis Books, 1998), 39.

${ }^{60}$ Hasel, "Divine Judgment," 189. "God's kingdom in Jesus' teaching has a twofold manifestation: at the end of the age to destroy Satan, and in Jesus' mission to bind Satan." Ladd, A Theology of the New Testament, 68 .

${ }^{61}$ Ladd, A Theology of the New Testament, 68.

${ }^{62}$ Hasel, "Divine Judgment," 900. Ladd offers an interesting perspective on a possible understanding about the present and future aspects of the kingdom of God existing soon after the exile. He says that "the truly Hebraic, prophetic hope expects the Kingdom to arise out of history and to be ruled by a 
For though He had come to this world to found the kingdom of God and fulfill the true spiritual meaning of the Messianic hope, He stated that the object of His mission would not be fully attained in that first coming. There was to be a break in His visible connection with earthly affairs (Matt 16:21). He would depart for a time (John 14:19; 16:7), but He promised He would come again to carry on His work to complete fulfillment (John 14:1-3) and bring the kingdom of God to its supreme triumph and glory (Matt 25:31-46). ${ }^{63}$

The message about God's kingdom also has both a good and a bad side according to what it represents to people - salvation or perdition. The good news is that God's prophesied kingdom of righteousness is at hand and judgment would bring shalom; the bad news is that none are righteous enough to receive that kingdom. Those realities were taught primarily in the parables recorded as part of the Sermon of the Mount, such as the ones about faithful and unfaithful servants, the prudent and foolish virgins, slaves who hid or invested their talents, and the sheep and the goats. Other parables such as the wheat and the weeds (Matt 13:24-30, 36-43), the dragnet (Matt 13:47-50), the banquet (Matt 22:1-8; Luke 14:15-24) also portray the reality of a final judgment.

In connection with His teaching on the kingdom of God, Jesus describes its nature. The kingdom parables of Matthew 13 are especially instructive in this sense.

Taken together these parables show that the spread and realization of the kingdom will be a process moving toward a day of judgment. Until that day good and evil will coexist, and the kingdom will be received by some and violently opposed by others. ... Its influence and spread will be subtle but nonetheless pervasive. The imagery of

descendant of David in an earthly setting (Isa. 9, 11). When this hope faded after the return from exile, the Jews lost hope of a Kingdom in history. In its place, they looked for an apocalyptic inbreaking of God in the person of a heavenly Son of Man with a completely transcendental Kingdom "beyond history" (Dan. 7). ... [In] the Old Testament, hope is always ethical and not speculative. It lets the light of the future shine on the present, that Israel may be confronted by history in the here and now. . . The prophets do not sharply distinguish between the near and the distant future, for both will see the act of God for his people" Ladd, 61.

${ }^{63}$ Hasel, "Divine Judgment,” 187-88. 
growth implicitly reminds us that the advancement of the kingdom is the work of God and not human effort (cf. 1 Cor 3:6-7). ${ }^{64}$

In the Sermon on the Mount, the main exposition teaches the values of the

kingdom with a focus on the real way to righteousness. The kingdom of God is

characterized by a wholeness of its citizens (Matt 11:4-5; Luke 7:22) in the context of the

broader understanding of shalom. All people are to live in harmony with God's will (Matt

7:21) rather than being mere imitators of other people's righteousness (Matt 5:20). Jesus'

message also fits in the context of the Old Testament and Judaism. It follows the Old

Testament as it teaches obedience, has similar condemnations as the Talmud, and even

affirms the law and the prophets (Matt 7:12). ${ }^{65}$ "The law of the kingdom is freshly

interpreted by Jesus . . . with the intent not to set the OT revelation aside, but to confirm

it." ${ }^{\prime 66}$ The misunderstanding about the law, characteristic of some scribes and Pharisees,

${ }^{64}$ Craig Ott, Stephen J. Strauss, and Timothy C. Tennent, Encountering Theology of Mission: Biblical Foundations, Historical Developments, and Contemporary Issues, Encountering Mission (Grand Rapids, MI: Baker Academic, 2010), 35.

${ }^{65}$ Hans Windisch, The Meaning of the Sermon on the Mount: A Contribution to the Historical Understanding of the Gospels and to the Problem of their True Exegesis (Philadelphia, PA: Westminster Press, 1951).

${ }^{66}$ Walter A. Elwell and Barry J. Beitzel, Baker Encyclopedia of the Bible, 2 vols. (Grand Rapids, MI: Baker Book House, 1988), 1862. On the one side, this idea is similarly articulated in the Handbook of Seventh-day Adventist Theology where it reads as following: "So Jesus, in the Sermon on the Mount (Matt. 5 ), does not nullify the precepts of the Decalogue, but strips away from them the accretions of erroneous tradition and reveals their true depth of meaning and application. The basic insights into this fuller import of the law were already in the OT, and Jesus enables these gems of truth to shine with even greater brilliance as they are freed from the distorted interpretations of some of the scribes and Pharisees." Hasel, "Divine Judgment," 66. One the other side, Jeremias expresses similar ideas while pointing out differences between the demands of Jesus and the ethic of Judaism, such as: (1) The Talmud brings a lot more than the Sermon on the Mount; (2) It is the decisive sayings that have no parallels in the Talmud; (3) The Sermon on the Mount as a whole "stands in conscious and decisive contrast to rabbinical-Pharisaic piety; and (4) "Jesus even goes so far as to set his teaching over against that of the Torah." Jeremias, Jesus and the Message of the New Testament, 20. 
was addressed by Jesus as He corrected views on the Sabbath and the year of Jubilee (Luke 4:19; Matt 4:17; Mark 1:15).

As Jesus taught about the way to righteousness and the law of the kingdom, He told "his disciples what he requires of them. He unfolds the will of God for them since this should determine their way of life." ${ }^{67}$ Commandments such as "You shall not kill" (vv. 21-26) and "You shall not commit adultery" (vv. 27-30) are mentioned as well as instructions for His followers to teach and practice those principles in connection with the kingdom of heaven ("he who does them and teaches them shall be called great in the kingdom of heaven," v. 19).

The Sermon on the Mount evidences how dramatically Jesus's understanding of the kingdom shifts away from conformity to outward forms to inward transformation. The values comprising the essence of the kingdom are fully contrary to the values of worldly kingdoms. Meekness, humility, servanthood, and nonretaliation, for example, characterize those who are great in God's kingdom. ${ }^{68}$

"The law deals with external behavior as well as with internal motivation. Here Jesus was clearly saying that its moral definition would not end with His teachings but continue in His new kingdom of eternal life." ${ }^{99}$ Therefore, the teachings of the Sermon on the Mount also “direct the gaze of Jesus' followers toward the future blessings that will arrive when the Son of Man returns."70 "They are to look to the parousia, not with dread but with confidence and joyous expectancy as their 'blessed hope' (Titus 2:13), because

\footnotetext{
${ }^{67}$ Jeremias, Jesus and the Message of the New Testament, 18.

${ }^{68}$ Ott, Strauss, and Tennent, Encountering Theology of Mission, 34.

${ }^{69}$ Hasel, “Divine Judgment,” 469.

${ }^{70}$ Harvey, "Mission in Jesus' Teaching," 41.
} 
of what the returning Lord already has done for them at the cross and during His high-

priestly ministry of intercession (Rom. 8:34; Heb. 4:15, 16)."

Thus, Latourette summarizes Jesus' message this way.

He believed that the kingdom of God was about to be inaugurated, and it was this which constituted the recurrent theme in his message. Obviously the kingdom of God meant a society in which God's will would prevail. As Jesus conceived it, the kingdom of God was to be a gift of God and was not to be achieved by men's striving. It was being inaugurated through Jesus and was both a present reality, already here, and a future hope. ${ }^{72}$

A final point should be made about a uniqueness of Jesus' teaching: He made His own identification His message. "Jesus is God's final revelation of what he requires of individuals to enter the kingdom, he is the way for the unrighteous to achieve the kingdom, and to live righteously. By repentance, faith in Christ, and following the Messiah, each person is again shown how to enter the kingdom." ${ }^{, 73}$ That is why the kingdom of glory can only be accessed through the kingdom of grace, seen now only by faith. While the previous aspects of Jesus' message were in line with Judaism, salvation through Jesus, as pointed out by Paul Spickard and Kevin Cragg, "was extravagant and blasphemous from a Jewish perspective."74

${ }^{71}$ Hasel, “Divine Judgment,” 189.

${ }^{72}$ Latourette, A History of Christianity, 1:38.

${ }^{73}$ Elwell and Beitzel, Baker Encyclopedia of the Bible, 1862. Jesus affirmed that in order to enter the kingdom one had to be born of the Spirit (John 3:5). Those who have been converted, who have received the baptism of water and the Spirit, are welcome in the kingdom of God. Hence the kingdom is within reach of the poor in Spirit (Matt 5:3), those who, like children, are ready to be instructed about the kingdom (Mark 10:14). Like the tax collectors and the harlots, they have repented and believed in Jesus (Matt 21:31, 32). Not all who call Jesus Lord will enter the kingdom of God, but only those who do the Father's will (Matt 7:21-23). The kingdom is ruled by God's law (Matt 5:17-20), and in order to enter life the observance of the commandments is indispensable (vv. 21-43; 19:17).

${ }^{74}$ Paul R. Spickard and Kevin M. Cragg, A Global History of Christians: How Everyday Believers Experienced Their World (Grand Rapids, MI: Baker Academic, 1994), 28. 
From this perspective, "the kingdom was where He was. The secret of being part of it, present or future, lay in belonging to Him (Matt 7:23; 25:41)."75 Therefore, Wright makes an important observation about the nature of Jesus's movement.

Jesus, I shall argue, redefined the hope of Israel in such a way as to call in question the normal interpretation of Jewish belief; Paul, seeing the hope thus redefined in practice around Jesus, completed in principle the task of the redefinition of belief. And both, in their own ways, demonstrated what this would mean at the level of halakah, of way-of-life. ${ }^{76}$

\section{Jesus' Ministry}

It is impossible to overestimate Jesus Christ's importance for and the impact on humanity. As announced in the Old Testament by his prophets, God, through His love and concern for His people, sent His Son to reveal His righteousness, establish His kingdom, and save His children. In order to understand the ministry of Jesus, one has to interpret it "in the setting of his view of the world and man, and the need for the coming of the kingdom; the eschatological dualism between the Day of the Lord and a divine visitation to cleanse the world of evil and sin and to establish God's perfect kingdom on earth, and the present order of things."77 Therefore, "the coming of Christ marks an era of renewal of his relationship with man, the renewal of the covenant and renewal of his kingdom on earth. The older covenant was mediated by Moses; the covenant was renewed by the Son of God, who came 'to fulfill all righteousness' (Mt 3:15).",78

${ }^{75}$ Hasel, “Divine Judgment,” 169-70.

${ }^{76}$ Wright, The New Testament and the People of God, 246.

77 “Jesus viewed this age as the domain of Satan, but did not see the created world as evil." Ladd, $A$ Theology of the New Testament, 45.

${ }^{78}$ Hasel, "Divine Judgment." 
Because of the different aspects of Christ's incarnation, Martin Hengel calls Jesus "the primal missionary." ${ }^{79}$ As John D. Harvey points out, Jesus' self-understanding indicates that, being sent by the Father, His task was to seek and save the lost, especially within the nation of Israel. He divides the organization of Jesus' understanding about His own mission into four groups: (1) the sender and the sent one, (2) the task, (3) the activities and scope, and (4) the message and the results.

The Sender and the Sent one is represented in Jesus' statement about His own mission as found in Matt 10:40, Mark 9:37, and Luke 9:48, which implies the existence of a sender, a sent one, and a close identification between the two. The Gospel of John, especially, has many references to God the Father sending His Son into the world (John $5: 19-24 ; 6: 38-39 ; 8: 38-42 ; 11: 41-42 ; 12: 44-50 ; 16: 25-28 ; 17: 1-6)$. That adds to the understanding about the Father as the one who takes the initiative in mission. Many dimensions of Jesus' divine identification with the Father are identified in the Gospel of John, such as knowledge, judgment, will, actions, and words (John 5:19-24, 30; 6:38; $8: 28-29 ; 12: 49)$. Of special significance, however, is His declared authority to forgive sins (Matt 9:6; Mark 2:10; Luke 5:24), that He is lord of the Sabbath (Matt 12:9; Mark 2:28; Luke 6:5), the law (Matt 5:17-48), and His sending others out into mission (Matt 28). Jesus' identification with the Father translates into submission to His will (Matt 26:42; Luke 22:42; Matt 26:39, 44; Mark 14:36) and carrying out of the Father's will with the Father's authority (Matt 21:23-27; Mark 11:27-33; Luke 20:1-8). ${ }^{80}$

\footnotetext{
${ }^{79}$ Martin Hengel, Between Jesus and Paul: Studies in the Earliest History of Christianity, 1 st Fortress Press ed. (Philadelphia, PA: Fortress Press, 1983), 62.

${ }^{80}$ Harvey, “Mission in Jesus' Teaching," 31-33.
} 
The task is often found in statements introduced by the phrase "I came." Some of those declarations connect His task with the past and express continuity in reference to fulfilling the Law and the Prophets (Matt 5:17) for example. ${ }^{81}$ Other similar statements reveal a salvific dimension of Jesus' task characterized by seeking lost sinners (Luke 19:10, Matt 18:11, Luke 9:56, Matt 18:12-14; Luke 15:3-7; Luke 15:8-10; Mark 2:17; Matt 9:13; Luke 5:32). That initiative involved mingling with the destitute and deprived in order to serve them to the point of giving up His life (Matt 8:1-17; Matt 20:28; Mark 10:45; Matt 26:28). His activity would not always be peaceful and, as anticipated by Jesus, His task would cause division (Matt 10:34; Luke 12:51; Luke 24:49-50). ${ }^{82}$

This integral understanding about Jesus' task reveals the framing of the kingdom in terms of its spiritual nature. "The kingdom is where God reigns, not merely politically or through a national entity, but first and foremost in spirit. People must be reconciled with God to enter his kingdom, and this would be the great work that Jesus comes to earth to accomplish. ${ }^{93}$ Even Jesus' healings, casting out demons, and miracles pointed beyond the physical realm to the spiritual nature of the kingdom of God, for Jesus had "broken into history in a new way to overthrow evil and reverse the effects of $\sin . " 84$ The activities and scope of Jesus' mission are also found in the Gospels. Preaching is often mentioned as the purpose of Jesus being sent (Luke 4:43, 44; Mark

${ }^{81}$ Also Matt 13:14; 26:54, 56; Mark 14:49; Luke 4:21; 21:22; 22:16; 24:44; and Matt 13:48; 23:32; Mark 1:15; Luke 21:24.

${ }^{82}$ Harvey, 33-36.

${ }^{83} \mathrm{Ott}$, Strauss, and Tennent, Encountering Theology of Mission, 29.

${ }^{84}$ Ibid. 
1:38; Luke 4:18, 19; Luke 8:12). The positive response to His preaching would result in the salvation of His listeners. However, Jesus' ministry is described as being more than 
preaching. Matt 4:23 describes Jesus' work by saying that "Jesus went through all the towns and villages, teaching in their synagogues, preaching the good news of the kingdom and healing every disease and sickness" (9:35). In Luke 4:18-19 one finds the declaration in which Jesus more clearly defines (with words of Isa 61) His work with four infinitives: (1) to preach good news to the poor, (2) to proclaim freedom to the prisoners and recovery of sight for the blind, (3) to release the oppressed, and (4) to proclaim the year of God's favor. As Lesslie Newbigin points out "the mission of Jesus was not only to proclaim the Kingdom of God, but also to embody the presence of the Kingdom of God in his own person," 85 which "made it possible for men and women to experience the present blessing of the kingdom." 86

Tennent points out the connection between both realities: "There is no wall of separation between the physical and the spiritual in His ministry, since His preaching and His healing are both signs of the inbreaking kingdom." As he further explains, "the inbreaking of God's rule has been inaugurated. The future realities of the great reversal have been set into motion." ${ }^{" 87}$ Besides the connection between the physical and spiritual realities of the kingdom, Jesus shows a connection between the present and future aspects of God's reign. "In this sense Jesus inaugurates the kingdom in his earthly life but does not fully realize it, nor does he anticipate its full realization until his return." $\$ 8$

\footnotetext{
${ }^{85}$ Lesslie Newbigin, The Open Secret: An Introduction to the Theology of Mission, rev. ed. (Grand Rapids, MI: W. B. Eerdmans, 1995), 40.

${ }^{86}$ Harvey, "Mission in Jesus' Teaching," 40.

${ }^{87}$ Tennent, Invitation to World Missions, 398.

${ }^{88} \mathrm{Ott}$, Strauss, and Tennent, Encountering Theology of Mission, 34.
} 
The message and the results refer to the scope of Jesus' mission as primarily to the Jewish people (Matt 15:24; Matt 10:5, 6; Matt 10:23). This understanding is also present in the parable of the vineyard owner (Matt 21:33-44). However, one should not fail to see a broader scope foreshadowed in His ministry. "Jesus' own ministry, his teaching, and the initial ministry of his disciples continues to minister under the Old Testament economy focusing primarily on Israel. But it also envisions a future intentional mission to the nations." ${ }^{89}$ That was in accordance with the Old Testament prophecies (e.g., Zech 9:9; Ps 72) that already pointed to a worldwide movement. Jesus "is thinking in terms of a kingdom that has become coextensive with the inhabited world." ${ }^{\prime 0}$ This idea is supported by the many references to a universal scope. Jesus mentions "all nations," "the whole world," the replacement of Israel as the inheritors of the kingdom, and exemplified His teachings with non-Jews. "Jesus anticipates the day when others will come from east and west, from north and south, and be included in the kingdom (Matt 8:11-12; Luke 13:29), an unmistakable reference to the inclusion of Gentiles." ${ }^{\text {91 }}$ This is even clearer through a few events in Jesus' ministry that seem to point to the future wider scope of mission. The centurion, the Gadarene demoniac, and the Canaanite woman are examples of non-Jews who were reached by His ministry. ${ }^{92}$

In some ways missionary zeal was characteristic of the Judaism of His time. As Jeremias points out, Jesus "came upon the scene in the midst of what was par excellence

\footnotetext{
${ }^{89} \mathrm{Ott}$, Strauss, and Tennent, Encountering Theology of Mission, 34.

${ }^{90}$ Neill, Christian Missions, 19.

${ }^{91}$ Ott, Strauss, and Tennent, Encountering Theology of Mission, 35.

${ }^{92}$ Harvey, “Mission in Jesus’ Teaching," 36-38.
} 
the missionary age of Jewish history." 93 However, the shifting understanding resultant of Jesus' mission demanded a different type of missionary activity. The clearest evidence of that seems to come from Jesus' strong observation about the Jewish mission in Matt 23:15. "It may be admitted that Jesus was condemning a superficial proselytizing, that his saying was aimed at the smug self-righteousness of the Pharisees and the fanaticism of their converts." Jesus' teaching and ministry, therefore, encompassed more than what could be accomplished by Him alone; it included the calling, training, and commissioning of His disciples.

\section{Jesus' Commission}

Although Jesus had already anticipated the advance of the Christian mission in universal terms before His resurrection, in the immediate post-resurrection context this becomes very prominent.

His own mission was completed, and his role changed from sent one to sender. In this new role he assumed many of the prerogatives previously ascribed to the Father. . . With the change in Jesus' role came another important change in the mission enterprise. The focus of mission shifted to Jesus' disciples. They were now the sent ones. ${ }^{94}$

The disciples of Jesus had been called to be prepared for mission (Matt 4:18-22; Mark 1:16-20; Luke 5:1-11) by participating in Jesus' ministry and having a relationship with Jesus. In two instances Jesus commissioned his disciples prior to His death (Matt 9:35-10:42; Mark 3:13-19; 6:7-13; Luke 9:1-6; Luke 10:1-20). In both contexts Jesus was concerned with people's spiritual needs (Matt 9:36) and physical consequences. The

\footnotetext{
93 Jeremias, Jesus' Promise to the Nations, 12.

${ }^{94}$ Harvey, "Mission in Jesus’ Teaching," 44-45.
} 
disciples are sent to proclaim Jesus' kingdom message (Luke 10:1; Matt 10:7; Luke 9:2), they received the same authority that Jesus exercised (Matt 10:1; Mark 3:15; 6:7; Luke 9:1), and engaged in the same activities that Jesus did (Matt 10:7-8; Mark 3:14-15; 6:7; Luke 9:1-2). Harvey also points out Jesus' orientation regarding the disciples' conduct: (1) “no elaborate preparations" (Matt 10:9-10; Luke 9:3; Mark 6:8-9), (2) “focus on responsive hearers" (Matt 10:11-15; Mark 6:10-11; Luke 9:4-5; 10:5-11), (3) knowledge about the circumstances (Matt 10:16; Luke 10:3), and (4) perseverance despite opposition and even persecution (Matt 10:23; 10:26-31). This leads to the conclusion that their conduct was to be also identical to that of Jesus', which takes on a new perspective after His resurrection.

The Great Commission demonstrates the new stage of the disciples' undertaking. Each of the four Gospels records Jesus' instruction as does the book of Acts. Each text connects with Jesus' ministry and encourages the disciples to go into the whole world. "The basic nature of their task continues to be that of extending Jesus' ministry." 95 They were disciples of Christ and were supposed to make disciples for Him.

Throughout the New Testament discipleship always involves attachment to a person, and most often that person was Jesus. In its most technical sense it is applied to the twelve apostles (Matt 10:1). More broadly it is used of those who follow him during his earthly ministry (John 6:60-66) and of Christians in general (Acts 14:28; 15:10, 19)... . Disciples are people who have a deep, abiding commitment to a person (Christ), not simply a philosophy. They hold to Jesus' teaching (John 8:31-32); they love one another (John 13:35) and help each other (Matt 10:42); they bear fruit for Christ (John 15:8) and are partners with him in service (Luke 5:1-11). All of these, when done in godly fashion, are acts of worship that glorify God the creator.

Disciples are the family of Jesus (Matt 12:46-50), putting him ahead of all other

\footnotetext{
${ }^{95}$ Harvey, "Mission in Jesus' Teaching," 45.
} 
earthly commitments (Matt 8:21-22; Luke 14:26-27) to the extent that they are willing to suffer for the sake of the gospel (Matt 10:17-23). ${ }^{96}$

“As the eleven obeyed Jesus' final words and made disciples who, in turn, were taught to obey those same words, a chain reaction would begin that would continue his mission until he returns." ${ }^{97}$

Jesus's final instructions to His disciples made clear God's purposes for His people. "Jesus did not inaugurate a Gentile mission during his lifetime, but after his resurrection he instructed his disciples to undertake such a mission."98 That new major emphasis on taking the gospel to all people was not clearly and readily understood by the disciples. Peter needed a triple vision and many evidences of the Roman centurion Cornelius's conversion. “The Holy Spirit had to interfere very often, directly or indirectly, so that the disciples of Christ would abandon a nominally Jewish conception of salvation." 99 At the same time, imitating the example of Jesus of ministering among people, the disciples avoided other misunderstandings such as the Essene model of asceticism. "The disciples did not renounce further association with society and think of

${ }^{96}$ Moreau, Corwin, and McGee, Introducing World Mission, 44. Mark gives special attention to the realities of discipleship failure and persecution and suffering. "Jesus' disciples, far from being a potent missionary force during Jesus' earthly ministry, are consistently shown to fail in their efforts to understand the true nature of Jesus' identity, the meaning of the cross and the thrust of his mission." Andreas J. Köstenberger and Peter Thomas O'Brien, Salvation to the Ends of the Earth: A Biblical Theology of Mission, New Studies in Biblical Theology (Downers Grove, IL: InterVarsity Press, 2001), 86.

${ }^{97}$ Harvey, "Mission in Jesus' Teaching," 49.

${ }^{98}$ Ibid., 38. About the shift to the mission to the Gentiles, see also Jeremias, Jesus' Promise to the Nations, 39.

99،"The book of Acts and several of Paul's letters help us to understand that many Judeo-Christians of the first century could never accept this." Jacques A. Blocher and Jacques Blandenier, The Evangelization of the World: A History of Christian Missions (Pasadena, CA: William Carey Library, 2013), 5. 
themselves as enthusiast apocalypticists waiting for the imminent appearance of the Son of man."

As Ladd concludes, "The ultimate meaning of history between the Ascension of our Lord and His return in glory is found in the extension and working of the Gospel in the world." 101 In order to accomplish that task God continued to have his agency. "The purpose of God was now to go forward through a new Israel, called into being through faith in Jesus Christ, the chief characteristic of which was to be its willingness to die and to rise again with him."102 Therefore, the good news should be seen beyond the aspects of incarnation, death, and resurrection of Jesus Christ. "An equally essential part of the Good News is that in this fragmented, divided, and hostile world, the message of forgiveness and reconciliation is to be preached to every racial, linguistic, and cultural group on earth." 103

\section{The Original Character of Christianity}

After a brief description of Jesus Christ and His mission, with special consideration of His message, ministry, and commission, it becomes clear that Jesus Christ is the center of Christianity. His character, His life, His teachings, His work, and His followers have established the nature of this worldwide missionary movement. 1982), 5.

${ }^{100}$ Leonhard Goppelt, Theology of the New Testament, vol. 2 (Grand Rapids, MI: W. B. Eerdmans,

${ }^{101}$ George Eldon Ladd, The Gospel of the Kingdom: Scriptural Studies in the Kingdom of God (Grand Rapids, MI: W. B. Eerdmans, 1959), 133.

${ }^{102}$ Neill, Christian Missions, 19.

${ }^{103}$ Paul Everett Pierson, The Dynamics of Christian Mission: History through a Missiological Perspective (Pasadena, CA: William Carey International University Press, 2009), 21. 
The Bible describes Jesus as having grown up in a faithful Jewish family. That is the context in which incarnation happens. There is no question that that portrait "provides [an] important background against which Christian self-understanding emerged.

Whatever else it may be, Christian identity is rooted in the prophetic promise of salvation found in Israel's life and faith." 104 There is obvious continuity and identification with Judaism in many ways, with John the Baptist establishing a prototype of the movement that would be founded with disciples that followed a way of living. The religion of Israel becomes the basis for the message, ministry, and mission of Jesus. However, Jesus is not only another Jewish prophet without implications for the Christian faith, as critical scholars, led by Bultmann, have suggested. ${ }^{105}$

The beginning of Christianity did not happen in a cultural vacuum or as a foreign religion in Palestine. Without creating a dichotomic view of spirituality, Jesus reshapes parts of that worldview from the inside, as one of them, as a Jew. Although His ministry had implication for all areas of life, Jesus still works from a Jewish cultural framework.

The realization that Jesus Christ, His nature, message, ministry, and commission, was incomparable took awhile for most people in the first century to realize. The first followers of Jesus were often thought of as members of a sect within Judaism. "But by the end of the century any Jew who confessed Jesus as Messiah was considered cursed or anathematized." ${ }^{\prime 06}$ History took a different course as the nature of Christianity became

\footnotetext{
${ }^{104}$ Dale T. Irvin and Scott Sunquist, History of the World Christian Movement (Maryknoll, NY: Orbis Books, 2001), 22.

${ }^{105}$ Jeremias, Jesus and the Message of the New Testament, 5.

${ }^{106}$ Pierson, The Dynamics of Christian Mission, 42. Within Judaism of the time of Christ one could find different trends, schools, and sects. The major ones were Hellenistic Judaism, Samaritans, Saducees,
} 
clearer and as Jesus' followers sought to live out the values of the kingdom of God.

The waning and disappearance of the groups of Christians who sought to remain within Judaism made it clear that the radical newness of the Gospel was not to be obscured by reducing Christianity to a Jewish sect. Christianity was now

unmistakably a separate religion, having rootage in Judaism and honouring the Jewish scriptures, but interpreting them as preparing for the basic and revolutionary novelty of Jesus and the Gospel. ${ }^{107}$

The revolutionary novelty of Jesus and the gospel could be analyzed from different perspectives. Neill, however, points out two factors: "A revelation which is of universal significance for mankind" and the commissioning of "disciples to go out and proclaim the message as widely as they could." 108

As for the significant revelation, on the one side, Drane compares Jesus' style of ministry with rabbis of that time and sees similarities in the fact that, in the context of the Palestinian countryside, wandering teachers with unique insights and followers to spread their teachings were commonly seen. He notes that the gospels seem to describe "how he himself followed this pattern, with twelve special followers to whom he entrusted the essentials of his teachings (Matthew 10:1-4)."109 On the other side, the uniqueness of

Pharisees, and the Essenes. It is in a Jewish context that Christianity is born. "In one sense Christianity was the outgrowth of Judaism. Yet in a very real way it was not the offspring of Judaism but was new. It was the culmination of Judaism, but it was more. . . . It was the fulfillment of Judaism, but it went beyond Judaism. At the outset it appeared to be another Jewish sect, although very small. Yet eventually it far outgrew in dimensions and influence all the Jewish sects combined. It did this because of distinctive qualities which at once related it to Judaism and distinguished it from Judaism. It was not just another Jewish sect. It was a new and fresh faith." Latourette, A History of Christianity, 1:18.

${ }^{107}$ Ibid., 1:122. Dunn suggests that Christianity "emerged from within the matrix of the longestablished Second Temple Judaism" in a similar way to the beginnings of new denominations within Christianity, such as the Reformation, Methodism, and Pentecostalism. It was a "renewal movement within a larger parent body. James D. G. Dunn, Beginning from Jerusalem, Christianity in the Making (Grand Rapids, MI: W. B. Eerdmans, 2008), 133.

\footnotetext{
${ }^{108}$ Neill, Christian Missions, 14.

${ }^{109}$ Drane, Introducing the New Testament, 10-12.
} 
Christianity, even among the major religions, lies in the fact that "its founder is also its message. Christians do not simply believe things that Jesus taught - they believe things about Jesus." 110 They believe that He is their Savior, Lord, and Intercessor.

Jeremias points out two important aspects of the relation between the message of Jesus and the origin of Christianity. "First, the good news of Jesus and the early church's witness of faith are inseparable from one another.... And second ... it is of utmost importance to recognize (and this is decisive) that they are not both on the same level ... [T] hey are related to one another as call and response." ${ }^{111}$ That cohesion, which can be challenging to maintain is found at the core of Christianity. Latourette seems to point once again to the person of Christ as the key. He says that "in the New Testament, the motive and basic principle of action is agape, love, love of God and love of man, inspired by the love of God, especially as seen in His self-giving in Christ and in the death of Christ for rebellious, sinful men on the cross." ${ }^{" 12}$ Jeremias also concludes that after studying the historical Jesus, the sources agree with this one fact.

A man appeared, and those who received his message were certain that they had heard the word of God. ... This claim to divine authority is the origin of Christianity. ... The study of the history of religions has amassed countless parallels and analogies to the message of Jesus.... Yet the more analogies we amass, the clearer it becomes that there are no analogies to the message of Jesus. There is no parallel to his message that God is concerned with sinners and not with the righteous, and that he grants them, here and now, a share in his kingdom. ${ }^{113}$

${ }^{110}$ Hill, Christianity, 8.

${ }^{111}$ Jeremias, Jesus and the Message of the New Testament, 13. "The historical Jesus and his message, therefore, are not one presupposition among many for the kerygma, but the sole presupposition of the kerygma." Ibid., 14.

${ }^{112}$ Latourette, A History of Christianity, 213.

${ }^{113}$ Jeremias, Jesus and the Message of the New Testament, 12. 
The kingdom of God, the central message of Christ, is introduced as both 'now' and 'not yet,' 'good news' and 'bad news,' and 'minuscule' and 'mighty.' In the Sermon on the Mount, He also teaches about the values of the kingdom as the real way to righteousness and harmony with God's will. The freshly interpreted law of God becomes the law of the kingdom. This new way of living is demonstrated by Jesus' ministry, both in words and deeds, as He traveled blessing people through preaching, teaching, and healing.

Besides being sent to fulfill His mission as the Messiah, Jesus is also a sender of people. His mission included the calling, training, and commissioning of His followers. Christ's disciples were mentored as Jesus ministered to people. After His resurrection, they became fully in charge of following the Holy Spirit and making other disciples of Christ from every ethnic group in every place by continuing the mission of Jesus.

Thus, the uniqueness of Jesus and his message could be seen in the impact on the lives of the people and the expansion of Christianity. The new followers not only had the spiritual aspects of their lives changed, but also their worldview and lifestyle. People transformed by their encounter with Jesus, nonetheless, continued to live and be a part of their culture. "The earliest Christians came to Christ, not simply as new creatures, but as human beings with personal histories and social environments. Their lives may have been transformed, their sins forgiven, and their eyes opened, but they continued to live their new lives in a social and historical context." ${ }^{114}$ And in all of this the goal is to reproduce and make disciples. It was a way of living, a way of being in the world.

\footnotetext{
${ }^{114}$ Spickard and Cragg, A Global History of Christians, 12.
} 


\section{CHAPTER 3}

\section{EXPRESSIONS OF CHRISTIANITY: BEING IN THIS WORLD AT DIFFERENT TIMES IN HISTORY}

Jesus's reshaping of the Jewish way of being in this world in His days defined the original character of Christianity, as described in the previous chapter, and gave way to the beginning of a movement. That was not just any kind of movement-Jesus Christ started a missionary movement. His teachings and example have been expressed in many different ways around the world over the past two thousand years. Since Jesus' death many people have claimed to be followers of His teachings. Throughout history many expressions of Christianity, as diverse as one can imagine both in terms of practices and beliefs, have developed. "Many of these differences arose as a result of the Christian faith crossing historical borders of language, culture, and identity. Time itself has introduced further changes in meaning, expression, and practice. The Christian movement is one that has continuously diversified itself through its expansions, all the while claiming to

remain the same."1 Although the various Christian movements would justify their relation to Christianity in some way, a true Christian movement should be modeled after Jesus and His way of living.

${ }^{1}$ Irvin and Sunquist, History of the World Christian Movement, vii. 
Many dynamics exist in reference to Christian movements. In general, expressions of Christianity have followed an ebb and flow, in which some had moved a long way from the original intent while others sought to restore and rekindle the core values of true Christian movements - the original character of Christianity as taught and exemplified by Jesus. Also relevant is the relationship between each of the selected expressions of Christianity and the original nature of Christianity. Finally, the relation between Christian values and the context of each movement is of special significance.

This chapter will analyze three selected expressions of Christianity in historythe early Christians, the Waldensians, and the Moravians. The study of each movement will also include a description of its context, its way of living, and its mission. The final section will discuss present global Christianity with special consideration given to current aspects of the context Christian movements face in the 21 st century.

\section{The Early Christians}

Jesus taught His disciples for over three years and then another forty days after His resurrection. After His ascension, it was up to His followers under the guidance of the Holy Spirit to fulfill the mission of God according to Christ's commission.

The importance of studying about the early Christians ${ }^{2}$ lies in the fact that this was the group directly connected to the living Christ; they interpreted the first expression of the teachings of Jesus; this was the group that helped shape Christianity as a collective

\footnotetext{
${ }^{2}$ The first group of believers after Jesus' ascension is often referred to as the early Christians. Other terms applied to the same group are church of Acts or the first century church. The researcher, in this section, assumes the historicity of the church and has limited the early Christians period to the first century AD.
} 
missionary movement. "It was in the first generation or so that the crucial moves were made which determined the direction that Christianity would take from then on. ${ }^{3}$ In many ways, those early Christians were part of a continuous historical development that flowed from Judaism to John the Baptist and Jesus from within the Greco-Roman context. This was the group of Christians which started within the Jewish world and quickly expanded to non-Jewish areas.

\section{Context}

The context of the early Christians was no different from that of Jesus' time. It is important however to include a summarized view of some key factors that were especially relevant for the development of Christianity. Some of the factors that favored the expansion of Christianity included the unity (maintained through roads, trade, and uniform administration $)^{4}$ and relative peace (Pax Romana) which Rome had imposed throughout its colonies, the Greek language adopted by the church, and the large presence of Diaspora Jews (and their synagogues) all around the empire. ${ }^{5}$ Other major contextual factors include the moral hunger, insecurity, and disasters that characterized that time period. From a philosophical-religious point-of-view, Neill remarks that "the age was perplexed by the transitoriness of all things and by the desire for immortality." "Stoicism was too lofty and dry, popular paganism metaphysically incredible and morally bankrupt,

\footnotetext{
${ }^{3}$ Wright, The New Testament and the People of God, 341.

${ }^{4}$ Pierson, The Dynamics of Christian Mission, 42-44.

${ }^{5}$ Neill, Christian Missions, 25.

${ }^{6}$ Ibid., 35.
} 
mystery-religions dark and forbidding, Judaism law-bound and introverted." $" 7$ Therefore, paraphrasing Paul's declaration in Gal 4:4, F. F. Bruce states that the "time was ripe" for Christianity. ${ }^{8}$

The whole thrust of Jesus' teaching was quite different from these world-denying systems of thought. But for that very reason it gave a more convincing explanation of life as it is in this world, rather than encouraging people to opt out and dream of the possibilities of life in some other world. The Christian message was firmly based on events that had taken place in the real world of everyday experience - the life, death and resurrection of Jesus. It did not require believers to distance themselves from life as they experienced it, but to understand this material existence as the context in which God was active, and could be known in a personal way. ${ }^{9}$

At that time, one group had developed a different way of living. After their discipling experience with the Lord Jesus, they had had a transforming experience when the Holy Spirit came on them at Pentecost. They had already witnessed power in Jesus' mission (Luke $2: 27 ; 4: 1,18$ ), in their own missionary training, and in the upper room (John 20:22). These experiences helped shape their lives and prepared them to shape the early church.

What joy must have been theirs, what a thrill must have resulted, electric in its effect on them, as the Divine Presence entered every fiber of their beings! Thus they must

${ }^{7}$ Wright, The New Testament and the People of God, 360.

${ }^{8}$ F. F. Bruce, The Spreading Flame: The Rise and Progress of Christianity (Grand Rapids, MI: W. B. Eerdmans, 1953), 24. Bruce believes Emperor Augustus and his decree mentioned in Luke 2:1 "played no small part in the ripeness of time for the work of Jesus and His followers." Ibid., 25.

${ }^{9}$ Drane, Introducing the New Testament, 27-28. "Christians also affirmed that a good life could not be achieved by human ingenuity and, without denigrating the value of human rationality (as the mystery religions tended to do), they claimed that reason was not capable by itself of discerning the meaning of life. True satisfaction could only be found, they argued, through a close personal relationship with God, which through the work of God's Spirit shared some of the characteristics of the mystical experiences so popular at the time, but by virtue of being rooted in the life and teaching of Jesus of Nazareth was always grounded in the historical realities of life in this world." 
have understood something of the significance of Christ's instructions to tarry, that the power of the Spirit might come upon them in fullness. ${ }^{10}$

By nature, however, following Christ implied having a personal experience that was dependent on a corporate reality. Self-fulfillment was connected to belonging to a new social grouping. ${ }^{11}$ This group had common values expressed through a common way of living.

\section{Way of Living}

The early church was an expression of Jesus' teaching and ministry, which had been inserted into the Jewish context. "From the first the Church was deeply conscious of its solidarity with Israel and of the continuity of God's action in the past with his present activity in Jesus of Nazareth and in his followers."12 As Spickard points out, this group looked like a Jewish subgroup since they kept some of their Jewish customs. The distinction between Jewish believers and the early Christians came fundamentally from belief in Jesus. "Jesus' followers claimed that he was the Messiah, the Promised One of Israel. But Jews expected that the Messiah would be a conqueror-not someone who had been executed as a criminal."13 That led to the development of a unique way of living.

\footnotetext{
10“The Early Christian Church," Seventh-day Adventist Bible Commentary, rev. ed., ed. Francis D. Nichol (Washington, DC: Review and Herald, 1976-1980), 6:22.

${ }^{11}$ Drane, Introducing the New Testament, 28.

${ }^{12}$ Henry Chadwick, The Early Church, The Pelican History of the Church (London: Penguin, 1967), 1:12.

${ }^{13}$ Spickard and Cragg, A Global History of Christians, 31. "In fact (this is the fourth point), firstcentury Judaism and Christianity have a central worldview-feature in common: the sense of a story now reaching its climax. And, most importantly, it is the same story. It is the story of Abraham, Isaac and Jacob; of Moses and the prophets; of David, Solomon, and the monarchy of Israel; and especially of exile and restoration - or rather, of puzzlement as to whether the exile was really over or not. Christians, of course, soon told the story with a rather different emphasis. But Jews and Christians continued to regard the story of Israel as the earlier chapters of their own story. It is here that fundamental continuity is to be sought; and
} 
Therefore, two aspects should be considered when describing the early church: the "distinctively Jewish character" but an identity that exhibited a clear continuity with the mission of Jesus, which Dunn identifies as the "chief factor for coherence." 14

Followers of Jesus were called Christians for the first time in Acts 11:26. When one speaks of the beginnings of Christianity before that, it is in an anachronistic way. As Dunn points out, the term "Christianity" is found for the first time in the 110s. ${ }^{15}$ Two other names were also associated with the early Christians in the beginning that help us understand the identity of the followers of Christ. First, the early Christians were known as Nazarenes, possibly because of Jesus' Galilean hometown. Another suggested meaning for that word derives from a root which means "to observe," and, in that context, it could mean the "observant people" in reference to those who observe a certain way of life. ${ }^{16}$ Second, they were referred to as followers of "the way" (Acts 9:2). "It was apparently used by both the Jewish and the secular community and appeared in both positive and negative assessments of the church $(19: 9,23 ; 22: 4 ; 24: 14,22)$. Paul's use of the term in his defense before Felix suggests that the name had at least quasi-official acceptance $(24: 14,22)$." This name offers another reference to the way of life of Jesus' followers since in the Bible the word "way" is often a metaphor of "modes of human

this legitimates the attempt to study Judaism in such a way as to shed light on emerging Christianity." Wright, The New Testament and the People of God, 150.

${ }^{14}$ Dunn, Beginning from Jerusalem, 16.

${ }^{15}$ Ibid., 5,6 .

${ }^{16}$ Bruce, The Spreading Flame, 70. As Bruce points out this title was probably not one chosen by themselves. It seems that they referred to each other, in the early days, by names such as "the saints" or "holy people," which were common Old Testament designations, "implying that they regarded themselves as the pious remnant or true Israel." Ibid. 
behavior." In this case it seems to derive directly from Jesus' statement that He is the “way" (John 14:6). ${ }^{17}$

Eventually the differences between the followers of Jesus and the Jews became much more obvious. The incarnation of Jesus Christ had enlarged, restored, and reinterpreted many aspects of Judaism. Jewish symbols like the Torah were no longer a code distinguishing Israel among the nations, the Land no longer marked the geography of the people of God, and the Temple was no longer the geographical and theological center. Jesus had forced a reinterpretation of these symbols. ${ }^{18}$ Those early Christians followed many of the values of Judaism, but the new revelation, Jesus Christ, was translated into their stories, symbols, and practices causing some to be eliminated, others to be replaced or even new ones to be adopted. The most obvious example is the Cross. ${ }^{19}$ This process reached a milestone at the stoning of Stephen.

Stoned by the orthodox Jews for his views, views which outraged their complacent assumption that they were a people peculiarly chosen by God to the exclusion of others, Stephen became, significantly, the first Christian of whom we know to suffer death for the faith. His tragic end made it clear that his convictions, inherent as they

\footnotetext{
${ }^{17}$ Elwell and Beitzel, "The Way," Baker Encyclopedia of the Bible, 2134. The metaphor of the way is found both in the Bible in other ancient literature. "The idea of two contrasting 'ways,' good and evil (Prov. 14:2; Matt. 7:13-14), is widespread (e.g., 1QS 3:13-4:26; the fable of Hercules at the crossroads, Xenophon Memorabilia ii.1.21-34). 'Way' often refers to a style of living, either evil or good (e.g., Ps. 1:6; Jude 11). It can also denote a habitual manner or activity, whether of animals (Prov. 30:19) or humans (Lam. 3:40; 1 Cor. 4:17). Death, for example, is 'the way of all the earth' (Gen. 19:31; RSV 'manner'; Josh. 23:14; 1 Kgs. 2:2). It is in the sense of this dichotomy that divine and human ways differ (Isa. 55:8-9).

By extension, 'the way(s) of the Lord' constitutes his will or law (Ps. 119), which is to be followed by believers (Deut. 8:6). In the Dead Sea Scrolls the Way also refers to the true faith (1QS 9:1718)." Allen C. Myers, "The Way," The Eerdmans Bible Dictionary (Grand Rapids, MI: W. B. Eerdmans, 1987), 1049.
}

${ }^{18}$ Wright, The New Testament and the People of God, 366. "The early Christians spoke of Jesus as the one who had embodied the living presence of the creator god, and of his own spirit as the one who continued to make that god present in the lives and assemblies of the early church."

${ }^{19}$ Ibid., 367. 
were in the Gospel and soon to be shared by the majority of Christians, would render it impossible for Christianity to be confined within the boundaries of Judaism. ${ }^{20}$

Christianity in the early church period was characterized by eight aspects. First of all, there was a burning conviction that "a great event had burst upon them in creative power. They knew that the world had been redeemed, and they could not keep to themselves tidings of such incomparable significance for the whole of the human race."21

Second, Christians maintained high moral standards that were similar to Jewish ethical views ${ }^{22}$ but with a renewed understanding and emphasis Christ had given. His life and teachings had stressed that moral behavior went beyond a code or a list of precepts. Ethics were grounded in the foundational principle of love for God and for each other. ${ }^{23}$

They were ordinary men and women like ourselves, living in the midst of a corrupt society and exposed to all its temptations. . . . Doubtless among the pagans there were many who lived upright and even noble lives... . The Christian, wherever he was, knew that he belonged to a society which was potentially world-wide, and which was bound together by the principles 'One Lord, one faith, one baptism.' . . One notable feature of this common life was the elaborate development of charitable service. ${ }^{24}$

Third, there was a sense of belonging. "The common life of the church, centred upon (though not of course limited to) this symbolic praxis and focus on Jesus, seems to have functioned from the first in terms of an alternative family." ${ }^{25}$ The familial

\footnotetext{
${ }^{20}$ Latourette, A History of Christianity, 67.

${ }^{21}$ Neill comments on Eusebius Eccles. Hist. 3.37.2-3. Neill, Christian Missions, 35.

${ }^{22}$ Hill, Christianity, 41.

${ }^{23}$ Ibid., 42.

${ }^{24}$ Neill, Christian Missions, 35.

${ }^{25}$ Wright, The New Testament and the People of God, 448.
} 
orientation of the early church went beyond a feeling of camaraderie to a loyalty that subverted illegitimate authorities in the name of Christ. ${ }^{26}$

Their oppressors they appease and make them their friends; they do good to their enemies ... they love one another, and from widows they do not turn away their esteem; and they deliver the orphan from him who treats him harshly. And he, who has, gives to him who has not, without boasting. And when they see a stranger, they take him in to their homes and rejoice over him as a very brother; for they do not call them brethren after the flesh, but brethren after the spirit and in God. And whenever one of their poor passes from the world, each one of them according to his ability gives heed to him and carefully sees to his burial. ${ }^{27}$

Fourth, they had a tenacious faith that endured persecution. There was an unshakable assurance "that in face of every obstacle men can be won and must be won for Christ, which was the mainspring of the whole enterprise." 28 If on the one side Christians had developed that kind of faith, as Wright points out, "choosing to become a Christian was not an easy or natural thing for the average pagan. A Jew who converted might well be regarded as a national traitor." ${ }^{29}$ Because of that, "every Christian knew that sooner or later he might have to testify to his faith at the cost of his life." 30 The persecution against the followers of Christ was essentially a direct consequence of a new reality in their lives that was more than a mere set of new beliefs. "The fact of widespread persecution, regarded by both pagans and Christians as the normal state of affairs within a century of the beginnings of Christianity, is powerful evidence of the sort of thing that

\footnotetext{
${ }^{26}$ Ibid., 449.

${ }^{27}$ Cited by Wright, The New Testament and the People of God, 363.

${ }^{28}$ Neill, Christian Missions, 35.

${ }^{29}$ Wright, The New Testament and the People of God, 360.

${ }^{30}$ Neill, Christian Missions, 38.
} 
Christianity was, and was perceived to be. It was a new family, a 'third race', neither Jew nor Gentile but 'in Christ.", 31 The influence of persecution on the early church can hardly be overstated. Hill comments that "Luke portrays this persecution as the catalyst that led to the movement spreading beyond Jerusalem, where it had been confined until this point." ${ }^{32}$ This view seems to receive support by the testimony of the pagan writer Celsus (c. 180): "He picked on the close-knit structure and coherence of the Christians as a social group, and saw in this the principal source of Christian strength. But in his view this social coherence was not the consequence of any internal principle but merely the result of being persecuted."33

Fifth, there was dynamic leadership. The pattern of leadership among early Christians included itinerant apostles and the development of local leaders. "A hierarchy of bishops clearly dominated in some locales, especially where leaders had known Jesus before his departure. In other places a group of elders or presbyters exercised a collective leadership resembling the ordinary synagogue pattern. In still other places grassroots leadership appeared through efforts to build consensus among the congregation."34

Sixth, baptism and the Lord's Supper were two of the most distinctive characteristics of the early church. ${ }^{35}$ The act of baptism had been introduced by John the

${ }^{31}$ Wright, The New Testament and the People of God, 450.

${ }^{32}$ Hill, Christianity, 25.

${ }^{33}$ Chadwick, The Early Church, 54.

${ }^{34}$ Spickard and Cragg, A Global History of Christians, 37.

${ }^{35}$ Hill, Christianity, 43-45. "It is clear, remarkably, that these two basic forms of Christian praxis were equally taken for granted as early as the 50s of the first century. Paul can write of baptism as a given, from which theological conclusions can be drawn (Romans 6:3-11). . . The retelling in the synoptic tradition of the original Lord's Meal, and the command to baptize, cannot therefore be seen as an attempt, 
Baptist and his movement within the Jewish context. However Wright also points out the eschatological aspect of that ritual. "Baptism was indeed the mode of entry into the eschatological people of Israel's god, it was this because it had to do with Jesus, who had himself brought Israel's history to its appointed destiny, and who as Messiah summed up Israel in himself." 36 The Lord's Supper also had important eschatological aspects as it pointed to the future reality of life in God's presence in His kingdom. ${ }^{37}$

Seventh, there was a focus on worship. The uniqueness of the early Christians worship was related to the recognition of Jesus as part of the reality of their one true God and Creator. "Mission and sacrament both came into focus at the very centre of the church's life, that is, its worship." 38

Lastly, there was an eschatological thrust. The roots of their expectations about the last days was in their understanding that Jesus was going to return very soon. ${ }^{39}$

These eight aspects formed the lifestyle of the early Christians that could be described as follows:

There was awe as God was at work through wonders and signs. There was generosity as believers shared their material fortunes as well as spiritual concerns. There were public meetings to proclaim Christ to their own people in the temple and private meetings in which they encouraged and taught one another. There was fellowship as

by the evangelists, to institute something not previously known." Wright, The New Testament and the People of God, 362.

${ }^{36}$ Wright, The New Testament and the People of God, 447. "The community, the ekklesia, had from the beginning a central symbolic, practical and theological role. Everything about it spoke both of the fulfillment of Israel's hopes and of a new role vis-à-vis the world."

${ }^{37}$ Hill, Christianity, 46.

${ }^{38}$ Wright, The New Testament and the People of God, 362.

${ }^{39}$ Hill, Christianity, 77. 
meals and life experiences were shared. Worship naturally occurred in all these settings, and it impressed outsiders favorably. ${ }^{40}$

What kind of phenomenon was this? "It was a new sort of movement that could only properly be described by creating a new category alongside Greeks, barbarians and Jews. It was a new way of construing what it meant to be human." 41

And, as with Judaism, we must remember that, though in many ways early Christianity appears to the post-Enlightenment world as a 'religion', within firstcentury categories it certainly did not. The early Christians were dubbed 'atheists'. They offered no animal sacrifices. What they did in their communal meetings bore some resemblances to non-Christian religious practices, but it was the differences that stuck out. The main thing that would have struck observers of early Christianity was not its 'religious' side, nor indeed its early doctrinal formulations, but its total way of life. $^{42}$

Despite a clear connection between the lives of the early Christians and the way of living Jesus modeled, the early church is an imperfect example. As the New Testament writers recognize, the church had not attained the ideal of Christianity. It was divided, had heresies, and moral issues. "The church, we may be sure, was never as totally pure and worthy as this, nor were its enemies as totally depraved as the apologists made out. But that there was a striking difference in general praxis as between pagans and Christians there can be no doubt."43

\footnotetext{
${ }^{40}$ Terry, Smith, and Anderson, Missiology, 78.
}

${ }^{41}$ Wright, The New Testament and the People of God, 365. "The characteristic actions and activities of Christians marked them out from the very beginning as a new sort of grouping in the ancient world. In many ways they were not like a 'religion'; they had no sacred sites, no animal sacrifices. They were not like a political group, since they looked for a kingdom not of this world. They were like Jews, not pagans, in that they gave allegiance to the one creator god, and they reused standard Jewish polemic against paganism. But they insisted, too, upon using the language of divinity for Jesus, and upon a completely nonracial fellowship, both of which put them decidedly outside the range of mainstream Judaism." Ibid.

${ }^{42}$ Wright, The New Testament and the People of God, 120.

${ }^{43}$ Ibid., 363. 


\section{Mission}

During the discipling of Jesus' followers, missionary activity had always played a central part. After Christ's resurrection, that mission became even clearer. As the disciples "adhere faithfully to his teaching and way of living, they are explicitly commanded to propagate his program, not just to Israel, but to 'the ends of the earth' (Acts 1:8). All this is to be under the guidance and enabling power of the Holy Spirit."44 Their new developing understanding about Christ, as also the One who died, rose, and ascended into heaven would become a key in their relationship with God that shaped their way of living, including their mission of spreading the good news. "It was an age in which the crucified Jesus was now regarded as Lord and Savior over all, for in his resurrection he was seen to transcend human limitations of geography and culture.” ${ }^{\natural 5}$ Drane suggests that "this was perhaps the one crucial factor which ensured the lasting success of the whole Christian movement. Because they believed that Jesus was not dead, but alive, his first followers were prepared to take the most incredible risks in spreading their message."46 Thus, it is important to realize, as Jeremias points out, the intrinsic connection between Jesus and His followers. "The gospel of Jesus and the kerygma of the early church must not be placed on the same footing, but they are related to one another as call and response" 47 The early Christian mission itself was not merely a key aspect of

\footnotetext{
${ }^{44}$ Terry, Smith, and Anderson, Missiology, 75.

${ }^{45}$ Irvin and Sunquist, History of the World Christian Movement, 1.

${ }^{46}$ Drane, Introducing the New Testament, 14. Beatings, imprisonments, shipwrecks, and persecutions of all kinds - even death - were commonplace in the life of the early churches (Acts 12:1-5; 2 Cor 11:23-27).

${ }^{47}$ Jeremias, Jesus and the Message of the New Testament, 13.
} 
praxis; it had a high symbolic value, since it only made sense on the premise that Jesus was enthroned as the true Lord of the world, claiming allegiance from all. ${ }^{48}$

At Pentecost, God was already operating according to the vision of reaching beyond Jerusalem. Among those who heard Peter's sermon and received the Holy Spirit were representatives of many ethnic groups who were in Jerusalem for the festivities and returned to their places of origin. This seemed to guarantee the expansion of Christianity into many new regions. Pierson points out, however, that it seems to have taken longer for the disciples to capture the wider scope of God's mission. "They were still very ethnocentric. ... They still thought of the Kingdom as belonging only to Israel. They had missed the point of Jesus' mission."49

Immediately the disciples were thrust into leadership roles over a large group of enthusiastic people. In the excitement many new believers stayed in Jerusalem to learn more. Jesus's people pooled their resources to feed and maintain the group, while they met together (in the temple) for prayer. Other converts returned to their homelands, taking the good news of Jesus to people in many parts of the Eastern Mediterranean world. ${ }^{50}$

After Pentecost, and especially due to persecution, Christ's followers began to move out from Jerusalem. "The names of the fifteen regions that Luke enumerated suggest an advance outward to the four points of the compass, and all of them are places where Christianity was planted very early in ancient times." ${ }^{51}$ The book of Acts describes

\footnotetext{
${ }^{48}$ Wright, The New Testament and the People of God, 367.

${ }^{49}$ Pierson, The Dynamics of Christian Mission, 21.

${ }^{50}$ Spickard and Cragg, A Global History of Christians, 31.

${ }^{51}$ Blocher and Blandenier, The Evangelization of the World, 7.
} 
in ever widening scope how Christianity reached the world. ${ }^{52}$ It also reports the dynamics involved in that process. As Christianity expanded beyond the Jewish people, among God-fearing Gentiles, practices of their faith were challenged. The climax of that situation was the Council of Jerusalem that resolved that Gentiles should not be required to become Jews. "The insights developed in this council unalterably shaped Christianity. It became a transcultural movement, not tied to historic Judaism or any particular human cultural pattern." 53

As a way of living, the gospel was orally spread everywhere including synagogues, marketplaces, streets, and private houses. "That proclamation was contextualized in many ways, one of them being the use of a language understood. ... Finally, that introduction to the good news was accompanied by acts of service and care. In many cases miracles and signs added to the powerful contact of people with God's plan of salvation. ${ }^{" 54}$ Rodney Stark cites Eusebius (Ecclesiastical History 3.37.3) who points out the "divine Spirit" in the Christian missionaries to the point that "at the first hearing whole multitudes in a body eagerly embraced in their soul's piety towards the Creator of the universe"

\footnotetext{
${ }^{52}$ Pierson, The Dynamics of Christian Mission, 22. "The narrative in Acts moved from Jerusalem, a Jewish center and provincial capital at one end of the Mediterranean, to Rome, the center of the empire and a gentile city. ... In addition, we know from the book of Romans that as Paul traveled to Rome, his goal was ultimately to go to Spain. Spain represented, for him, the end of the earth."

${ }^{53}$ Spickard and Cragg, A Global History of Christians, 33. The importance of the decisions made at the Council of Jerusalem, as described in Acts 15, to the consolidation of Christianity as a worldwide movement cannot be overestimated.

${ }^{54}$ Blocher and Blandenier, The Evangelization of the World, 13.

${ }^{55}$ Rodney Stark, The Rise of Christianity: How the Obscure, Marginal Jesus Movement Became the Dominant Religious Force in the Western World in a Few Centuries (San Francisco, CA: HarperSanFrancisco, 1997), 13.
} 
During the Early Church period, Paul is the missionary par excellence. He dedicated himself to reach out to the Jews and to go to the ends of the earth. He never spent more time than was necessary for Christianity to take root in a local community. ${ }^{56}$ The success of the Pauline mission has been attributed to different complementary reasons. Jeremias points out that "the overwhelming success of the mission of the apostle Paul ... depended partly on the fact that everywhere he was able to build on ground prepared by the Jewish mission." ${ }^{57}$ Chadwick emphasizes Paul's ability to go beyond common Jewish ground and reach Gentiles and suggests that "perhaps the chief reason for Paul's success was his extraordinary versatility and capacity for adapting himself to the situation of his audience." 58

Barnabas, Silas, and many others also became itinerant missionaries, but the majority of the followers of Christ did not have that type of engagement in mission. They were what Neill calls, "the anonymous and unchronicled witness of all the faithful." Every Christian was a witness. "Where there were Christians, there would be a living, burning faith, and before long an expanding Christian community." Therefore, the conclusion is that the early Christians formed a "genuinely missionary" movement. ${ }^{59}$

${ }^{56}$ Neill, Christian Missions, 27.

${ }^{57}$ Jeremias, Jesus' Promise to the Nations, 16. “The impact of Paul's organized ministries in synagogue throughout the Diaspora was strengthened by the destruction of the Jewish Temple in 70 C.E. under the Flavian emperors Vespasian and his son Titus. This war is considered by many to be the clear break between Judaism and Christianity." White, The Emergence of Christianity, 14.

${ }^{58}$ Chadwick, The Early Church, chap. 3.

${ }^{59}$ Neill, Christian Missions, 22. "World mission is thus the first and most obvious feature of early Christian praxis." Wright, The New Testament and the People of God, 361. 


\section{Spread and Growth}

One of the most striking aspects of early Christianity as a missionary movement was how quickly it spread. "In AD 25 there is no such thing as Christianity: merely a young hermit in the Judaean wilderness, and his somewhat younger cousin who dreams dreams and sees visions. By AD 125 the Roman emperor has established an official policy in relation to the punishment of Christians." $" 60$

As mentioned before, in many ways the Christian message was well received. ${ }^{61}$ "Christianity did not spread by magic. . . Christianity burst on the scene as the great answer to the questions everyone was asking" ${ }^{62}$ Drane points out that "Jesus' claim to be the fulfillment of the Old Testament faith gave his followers a head start. Greeks and Romans - and expatriate Jews_ - naturally wanted to know what the Christians had to say." 63 Therefore, Christianity received a favorable acceptance especially among Jews in the beginning, from which it drew its adherents despite the different sects and diversity. ${ }^{64}$ The Christian message found similar response among the peoples of the Roman Empire as "it showed a capacity to satisfy both the craving for salvation which the mystery cults professed to meet and the ethical ideals which, as many Gentiles believed, were realized in the Jewish way of life even more than in Stoicism."65

\footnotetext{
${ }^{60}$ Wright, The New Testament and the People of God, 359.

${ }^{61}$ Neill, Neill, Christian Missions, 35.

${ }^{62}$ Wright, The New Testament and the People of God, 360.

${ }^{63}$ Drane, Introducing the New Testament, 26-27.

${ }^{64}$ Chadwick, The Early Church, 15.

${ }^{65}$ Bruce, The Spreading Flame, 24.
} 
The natural relationships of society were the primary channels of influence for Christianity. It spread primarily by word of mouth (Jewish scriptures were part of their conversations especially when witnessing to Jews), but it was more than that. Jesus' teachings were orally communicated and personally embodied. Thus, "it is intrinsically very likely that people generally became Christians because they had close friends or relations who were Christians: that is, the religion spread through already existing personal ties. ${ }^{~}{ }^{66}$ Moreover, the stories found in Acts of entire households being converted and baptized and the people greeted in the New Testament letters and their families indicate that that process happened both on an individual as well as a collective pattern. Hill makes an important observation that Christianity spread through existent social and kinship ties but it also created its own. "To join the church was to shift one's social centre of gravity. Moreover, the geographical spread of the Christian movement meant that a convert to Christianity became involved in something much wider than just a small circle of friends with a shared faith. ${ }^{97}$ The Bible also describes public preaching to large groups (e.g., Acts 2). The combination of all those dynamics, to individuals, to families, and to large groups, seem to account for the rapid expansion in the early church. ${ }^{68}$ Thus,

${ }^{66} \mathrm{Hill}$, Christianity, 37. "We have seen how small religions typically spread through existing social networks, and how Christianity seems to have conformed to this model. But the very first Christians were Jewish, and Jews typically associated mostly with one another, so we might expect Christianity to have spread almost exclusively among Jews." Ibid., 63.

${ }^{67}$ Hill, Christianity, 37.

${ }^{68}$ Ramsay MacMullen, Christianizing the Roman Empire: A.D. 100-400 (New Haven, CT: Yale University Press, 1984), 29. 
the conclusion that the early church was "one of the first mass movements in Christian history." 69

The followers of Jesus understood that they should witness beyond Jerusalem, and so it happened, beginning in urban centers. Outside Palestine, Antioch of Syria became "the second home of the Church" (Acts 11:26), Asia Minor was "one of the most promising fields for Christian work," Rome developed a large Church at the crossroads of the capital, Alexandria and Cyrene hosted the Church in Egypt very early on, and North Africa had "the first Latin-speaking churches of the world." At first, Christianity had a city focus, but gradually expanded into country areas. At the turn of the first century one could testify of its wider reach. A letter from Pliny to the Emperor Trajan (around 112) mentions Christians "in every period of life, on every level of society, of both sexes ... in towns and villages and scattered throughout the countryside."70

Therefore in response to the inquiry about the growth and spread of early

Christianity, Wright emphatically summarizes his explanation this way:

Early Christians believed that what they had found to be true was true for the whole world. The impetus to mission sprang from the very heart of early Christian conviction. ... 'The irresistible expansion of Christian faith in the Mediterranean world during the first 150 years is the scarlet thread running through any history of primitive Christianity.' This missionary activity was not an addendum to a faith that was basically 'about' something else (e.g., a new existential self-awareness). 'Christianity was never more itself than in the launching of the world mission."

\footnotetext{
${ }^{69}$ Neill, Christian Missions, 28.

${ }^{70}$ Neill, Christian Missions, 28-35. Neill cites Pliny, Epistles x, 96, 97 through J. Stevenson, A New Eusebius (1957), 13-16.

${ }^{71}$ Wright, The New Testament and the People of God, 360.
} 
A major development in this expansion was the recognition of Christianity as the official religion of the Roman state in 313 when Constantine, a recent convert, became emperor. "When their movement came to the attention of the Roman authorities, it was brutally suppressed. Yet little more than three centuries later, the Christian religion had become the faith of the empire itself."72

\section{Christianity Becomes a Movement}

The first group that lived out Christianity after Christ ascended was the early Christians. The importance of researching this group lies primarily in their connection to the living Christ. This group had been aware of Jesus' life. They lived in the same social, political, and philosophical context as Jesus and His disciples. Some of those contextual factors are identified as favorable to the development of Christianity, especially since they offered a more convincing way of living than the other systems.

The early Christians lived in the Jewish context and were followers of Jesus Christ. This led to a new identity as the Nazarenes and followers of the Way. The controlling story, symbols, and hope of this group were reinterpreted by Jesus Christ (i.e., the cross). The gradual process of detachment from Judaism was marked by the stoning of Stephen.

The way early Christians lived can be characterized by eight aspects: (1) a burning conviction, (2) high moral standards, (3) a sense of belonging, (4) a tenacious faith, (5) dynamic leadership, (6) distinct rituals of baptism and the Lord's Supper, (7) a

\footnotetext{
${ }^{72}$ Hill, Christianity, 7. Studies about Constantine's conversion and the establishment of Christendom help to develop a balanced view of the implications of that decision to the vitality of the expressions of Christianity especially in the West as a major factor in changing Christianity from a movement to a political institution.
} 
focus on worship, and (8) an eschatological thrust. Those early Christians did not embrace a set of beliefs but a total way of life. The New Testament leaves no doubt about the struggles that the early Christians faced as they sought to be followers of Christ. "The ideal of Church appears again and again in the early Christian documents which compose the New Testament and which reflect the convictions of leaders in the primitive Christian fellowship." ${ }^{.73}$ Nonetheless, Hill underlines two major elements of the nature of Christianity as expressed by early Christians:

The first is that it shows that Christians are not simply people who believe in the Christian message and hope that Jesus will return soon. They are people who have an active and very intimate relationship with Jesus right now. To be a Christian is to be transformed; it is to have one's inner nature renewed no matter what one's external circumstances ( 2 Corinthians 4:16). And second, the 'in Christ' language is always communal. The Christian does not simply enjoy union with Christ; he or she enjoys union with all Christians, with the church as a whole. ${ }^{74}$

Following the movement that Jesus began, His disciples continued the pattern of spreading the good news. The understanding that their Lord was the Messiah who had been among them, that He had died, and had risen from the dead, and Jesus' commands and empowerment at Pentecost motivated them to risk even their lives in mission.

Seemuth draws an important conclusion about the transition from Christ and His disciples to the early Christians:

It is important to recognize that the admonishment toward mission in the New Testament had both an explanatory role and a motivational role. Mission was already occurring. ... The early church realized that God's own 'missionary zeal' and merciful actions were evident in their midst. ... Indeed, the early church owed its

\footnotetext{
${ }^{73}$ Latourette, A History of Christianity, 113.

${ }^{74}$ Hill, Christianity, 34.
} 
very existence to the combination of a God who desired to save and people who were willing to be the agents of God's redemptive work. ${ }^{75}$

As Christianity came in contact with other contexts, some of its practices were challenged to the point that the Council of Jerusalem was necessary to discuss those issues. That was an important step for Christianity to become a truly transcultural missionary movement.

Because of their way of living, every Christian was a witness and everywhere was a proper place to share the gospel. Some Christians were full-time missionaries, but there was a "mass of unprofessional missionaries."76

The extraordinary progress of Christianity in the course of a generation can only be explained if most Christians - men and women - are seen to have been witnesses for Jesus Christ. The gospel was carried along Roman roads by Christian merchants and soldiers. The witnesses of Christ proclaimed the gospel message through the normal social channels of family members, neighbors, and work companions. Christians at this time were not disposed to meet in 'sanctuaries,' but assembled for their worship services in the home of those among them who had houses best suited to the purpose. $^{77}$

Christianity in the beginning already displayed a mix of uniformity and diversity.

"The existence of travelling preachers and other church leaders ensured that there was some uniformity to the movement, whose members all traced their spiritual heritage back to Jesus himself and the first disciples. But each community, in each city, was also selfgoverning, and different social structures evolved in different ones." ${ }^{, 78}$ All these dynamics

\footnotetext{
${ }^{75}$ David P. Seemuth, "Mission in the Early Church," in Mission in the New Testament: An Evangelical Approach, American Society of Missiology Series, ed. William J. Larkin and Joel F. Williams, (Maryknoll, NY: Orbis Books, 1998), 56.

${ }^{76}$ Neill, Christian Missions, 26.

${ }^{77}$ Blocher and Blandenier, The Evangelization of the World, 12.

${ }^{78}$ Hill, Christianity, 52.
} 
contributed to the shaping of the character of Christianity as a genuinely missionary movement.

A way of living with a mission orientation led to one of the most striking aspects of early Christianity: it was a missionary movement that spread rapidly. In the first century, through webs of natural relationships, the gospel received many positive responses and expanded beyond Palestine to most of the then-known world to become one of the first mass movements in Christian history. In summary, the early Christians allowed the seed of a missionary movement, contained in the gospel, to germinate by developing a specific way of life taught and exemplified by Christ.

\section{The Waldensians}

Christianity continued to grow and find expression in different contexts throughout its history. After the expansion during the apostolic period and the next three hundred years it grew throughout the Roman Empire. However, a review of mission history will point out that by the early fourth century the first signs of decline in vitality appeared. Although viewed at the time as the triumph of the gospel, the Constantinian institutionalization and the great recession from AD 500-950 offered challenges to Christianity. During this time the monastic movements and the Celtic church were examples of vigorous Christianity. But these were not the only ones; there were other popular religious movements that embraced the full practice of the Christian life both 
inside and outside the church. ${ }^{79}$ The second Christian movement selected for this investigation is the Waldensians - a missionary movement.

\section{Context}

During medieval times, the church was powerful and corrupt. The majority of the people in the West called themselves Christians, "but their understanding and practice of the Faith were at a low level." 80 Within the church, there was a growing dissatisfaction with unbiblical practices, such as church structure, its wealth, the papacy, and some sacraments of the Roman Church. ${ }^{81}$ As a result, medieval lay movements, one of the most important expressions of Christianity before the Reformation that included Albingensians and Waldensians, came onto the scene. Waldensians, in particular, reflected the vitality of Christianity as a minority movement while displaying an ardent missionary spirit toward nominal Christians. ${ }^{82}$ The main thrust of this movement was the urging of people to live good Christian lives; an emphasis on the ethical aspects of the gospel instead of the institutional, ecclesiastical view. G. R. Evans points out that "they wanted to return to the

\footnotetext{
${ }^{79}$ Jenkins, for example, describes dynamic expressions of Christianity outside of Europe that he refers to as Eastern Christian churches. Philip Jenkins, The Lost History of Christianity: The ThousandYear Golden Age of the Church in the Middle East, Africa, and Asia-and How It Died, 1st ed. (New York: HarperOne, 2008).

${ }^{80}$ Pierson, The Dynamics of Christian Mission, 109.

${ }^{81}$ Some of these preachers were Tanchelm of Utrecht, Henry of Lausanne, Arnold of Brescia, and Peter of Bruys. Ibid., 110.

${ }^{82}$ Latourette, A History of Christianity, 1:447.
} 
life they believed the apostles had led, which they said must surely be closest to what Jesus had intended for his followers." 83

The Waldensian movement developed during a time of transformation in European society. During the change from a feudal to a commercial society, the middle class emerged. This middle class was positioned between the nobility and the serfs and were "the bourgeoisie - the townspeople, the traders and small manufacturers." ${ }^{84}$ Peter Waldo (or Waldes or Valdes), the lay leader of the movement, was born in Lyons, in southern France, around 1140. He was a merchant who became very rich; apparently, not through the most ethical ways until he experienced a spiritual awakening. "Tradition says that Waldo heard the legend of St. Alexis, who said that the true Christian is willing to give up all and follow nakedly a naked Christ, to be a pilgrim, and call no place on earth home." 85 In 1176, Waldo decided to give away his wealth, follow Christ, and preach the gospel. His preaching attracted many people who became part of his movement. His disciples were known as the "Poor in Spirit" or the "Poor Men of Lyons." 86

A distinction in Waldo from earlier wandering preachers was "his concern as a layman for self-instruction through vernacular translations of Scripture and the

${ }^{83}$ G. R. Evans, The Roots of the Reformation: Tradition, Emergence and Rupture (Downers Grove, IL: IVP Academic, 2012), 187.

${ }^{84}$ Pierson, The Dynamics of Christian Mission, 111.

${ }^{85}$ Ibid., 112. After considering the experience of the early expansion of the church in chapter two of The Dynamics of Christian Mission, Paul Pierson mentions Peter Waldo as the first name in a list of key spiritual leaders "who have sought God deeply and have listened to Him profoundly." According to him, as result of that, there "has been new vision that reflected the heartbeat of God for the world." Ibid., 27.

${ }^{86}$ Latourette, A History of Christianity, 1:451. Waldensians reacted to the way of living of church clergy since they were disgusted "at the sight of bishops on fine horses and wearing rich clothes" Evans, The Roots of the Reformation, 138. 
Fathers." ${ }^{\circ 7}$ This is how Pierson describes Waldo and his followers:

They saw the Bible, primarily the New Testament, as a book of laws. They sought to be as literal as possible in their biblical interpretation. They attempted to follow the Sermon on the Mount literally. They would not take any oath or shed any blood. They did not resist. They were pacifists. They went out two by two to preach to the poor, and lived from the offerings of the believers.... They criticized the use of Latin, a language that the common people did not understand. They eventually rejected all of the sacraments except those they found in the New Testament--baptism and the Lord's Supper. They also rejected the hierarchy of the Church. ${ }^{88}$

Way of Living and Mission

That direct contact with Scriptures seems to have led to the development of a specific way of life. From the beginning Waldo's group was consisted of poor, itinerant preachers. ${ }^{89}$ The way of life of the Waldensians is described as "going about two by two, barefoot, clad in woolen garments, owning nothing, holding all things [in] common like the apostles, naked, following a naked Christ." ${ }^{\text {90 }}$ Latourette points out that "even their enemies described them as dressing simply, industrious, laboring with their hands, chaste, temperate in eating and drinking, refusing to frequent taverns and dances, sober and truthful in speech, avoiding anger, and regarding the accumulation of wealth as evil.".91

As far as their spiritual life was concerned, their lifestyle included the memorization of large portions of the Bible, denial of the traditional teaching on masses,

\footnotetext{
${ }^{87}$ Malcolm Lambert, Medieval Heresy: Popular Movements from the Gregorian Reform to the Reformation, 3rd ed. (Malden, MA: Blackwell, 2002), 71.

${ }^{88}$ Pierson, The Dynamics of Christian Mission, 112.

${ }^{89}$ Gabriel Audisio, The Waldensian Dissent: Persecution and Survival, C. 1170-C. 1570, Cambridge Medieval Textbooks (New York: Cambridge University Press, 1999), 111.

${ }^{90}$ Walter Map, cited in Lambert, Medieval Heresy, 72.

${ }^{91}$ Latourette, A History of Christianity, 1:453.
} 
prayers for the dead, and purgatory, and insisting that prayer should not be restricted to churches. "They observed the Eucharist together and held that, if necessary, any layman might administer it. Their only forms of prayer were the 'Our Father' and grace at meals." 92 The Waldensians also rejected the church patterns for the priesthood as they sent out both laymen and laywomen to preach. "They were one of the first groups after second century Montanism to permit and encourage women in ministry." 93 The early Waldensian Sisters followed the same way of life including learning about the Bible and preaching. In fact, it would be safe to say that [the Waldensians] not only believed that women could teach "but that they ought to teach.",94

Waldensians traveled in small groups of missionaries preaching popular sermons to ordinary people. As expected, since both preachers and non-preachers demonstrated remarkable Bible knowledge, their preaching involved the repetition of many texts of Scripture learned by heart. ${ }^{95}$ "From the earliest days of their movement, the Poor of Lyons took books with them on their evangelizing missions." 96

There is some evidence that the early Waldensians formed not only a movement of poverty and preaching but a movement of poverty, preaching, and healing the sick. "It further suggests the possibility that the later underground movement of poor and

\footnotetext{
${ }^{92}$ Latourette, A History of Christianity, 1:452.

${ }^{93}$ Pierson, The Dynamics of Christian Mission, 112.

${ }^{94}$ Peter Biller, The Waldenses, 1170-1530: Between a Religious Order and a Church, Variorum Collected Studies Series (Burlington, VT: Ashgate, 2002), 139.

${ }^{95}$ Lambert, Medieval Heresy, 81.

${ }^{96}$ Audisio, The Waldensian Dissent: Persecution and Survival, C. 1170-C. 1570, 147.
} 
wandering Brothers continued these activities, using simple medicine as they used simple sermons" as a sign of their inspiration and imitation of the apostolic model. ${ }^{97}$ As Biller points out, "Waldensians figure high among the protagonists in accounts of medieval pacifism." ${ }^{98}$ Waldensians spread initially through Austria, Bohemia, and Moravia, and later to Germany, Hungary, and Poland. Even some princes and magistrates were reputed to be Waldensians. ${ }^{99}$

Lambert concludes that the Waldensians "drew converts above all because of the attractive power of the earnest and dedicated lives of many of their teachers and the force of their exhortation to moral living in their hearers." 100 Therefore, the majority of the people who came in contact with the Waldensians perceived their doctrine as less distinctive than their godly way of life. ${ }^{101}$

Nonetheless, the Waldensians are often portrayed by historians as heretics. ${ }^{102}$ They started by refusing to accept the authority of the pope. Spickard and Cragg, for example, reason that "the Waldensian's initial rejection of the institutional church's administrative authority eventually led them to challenge its doctrinal authority. This sent

\footnotetext{
${ }^{97}$ Biller, The Waldenses, 1170-1530, 67. Biller also suggests a connection between religious movements like the Waldensians and the hospital movement, and hospital orders that originated in late twelfth and early thirteenth centuries.

${ }^{98}$ Ibid., 81.

${ }^{99}$ Pierson, The Dynamics of Christian Mission, 113.

${ }^{100}$ Lambert, Medieval Heresy, 95.

${ }^{101}$ Euan Cameron, Waldenses: Rejections of Holy Church in Medieval Europe (Malden, MA: Blackwell Publishers, 2000), 30.

${ }^{102}$ Russell calls Waldensianism "the strongest and most enduring Reformist heresy of the Middle Ages.” Jeffrey Burton Russell, Dissent and Order in the Middle Ages: The Search for Legitimate Authority, Twayne's Studies in Intellectual and Cultural History (New York: Twayne Publishers, 1992), 44.
} 
them in the direction of another type of heresy — theological teaching that contradicted the consensus of the church." 103 Waldensians, however, differed from Albigensians and Cathars, and did not see themselves as fundamentally heretics or schimatics, but as reformers. "They were the first major group of dissidents in the tradition which was to lead on to the Lollards and to Reformation ideas."104

The official church began to fear their influence and their different approaches to traditional doctrines. Since only those licensed by the church could preach they were unable to continue under the approval of the church. ${ }^{105}$ In 1179 Waldo requested official permission to preach from his bishop but his request was denied. He tried again with the Pope at the Third Lateran Council in the same year with no success. He was excommunicated in $1184 .^{106}$

Even though the Waldensians were terribly persecuted by people like Conrad of Marburg, a papal investigator, they suffered less than the Cathars and were considered less dangerous. Despite the fact that Waldensians were rejected by the Roman Church, they had a powerful impact in Europe from the twelfth and thirteenth centuries on. According to Evans, in the seventeenth century the Waldensians were still a threat in

\footnotetext{
${ }^{103}$ Spickard and Cragg, A Global History of Christians, 95. "One of the most important features of the claims of the Waldensians and the Lollards had been that the faithful could be saved without a ministry of the Word and sacraments offered in and through the institutional church by properly approved ministers." A clear challenge to Augustinian doctrine nulla salus extra ecclesiam. Evans, The Roots of the Reformation, 336.

${ }^{104}$ Evans, The Roots of the Reformation, 194.

${ }^{105}$ Ibid., 187.

${ }^{106}$ Latourette, A History of Christianity, 1:452.
} 
Piedmont, Italy, when the Duke of Savoy arranged to massacre them. ${ }^{107}$ The Waldensian movement waned "partly because of investigations but mainly because of schisms within their own ranks."

In order to guarantee the survival of the movement Waldensians were forced to operate clandestinely and accept a more rigid organization. "The Poor of Lyons lost certain remarkably subversive traits by opting to ensure their future. . . In the century following the birth of the Waldensian movement, profound changes took place, the most noteworthy being their adoption of a clear hierarchy."109

\section{A Restorationist Missionary Movement of the Middle Ages}

In the medieval, obscure, spiritual context of the twelfth and thirteenth centuries, a Christian movement emerged that sought to restore the true nature of Christianity. The disenchantment of Peter Waldo with the reality of the church motivated him to live a life that reflected Jesus' teachings and example and that produced the Waldensian movement.

Within the character of the Waldensian movement one can identify characteristics similar to the Early Christian expression of Christianity. Waldensians had a burning conviction that people should hear biblical preaching from those with high moral standards that led them to seek to help the poor and the sick around them. The

${ }^{107}$ Evans, The Roots of the Reformation, 188.

${ }^{108}$ Russell, Dissent and Order in the Middle Ages, 57. The inquisitio heretice pravitatis (investigation of heresy) defined Waldensianism as a heresy. "The decree made clear ... that the struggle against heresy was no longer primarily theological; rather, it was a concentrated effort by the leaders of ecclesiastical and civil order to preserve and enhance their powers at a time when those power were perceived to be under serious attack." Ibid., 60.

${ }^{109}$ Audisio, The Waldensian Dissent, 115. 
Waldensians were very community-oriented with a tenacious faith that helped them endure persecution. Their dynamic leadership relied on lay people to get involved in Mission; they rejected the sacraments of the church, but kept biblical baptism and the Lord's Supper. They led lives of worship in anticipation of the soon end of the world. ${ }^{110}$ Their missionary movement was based on a way of living, a way of being in the world.

The Waldensian emphasis on individual access to a vernacular Bible, and their proposal to follow Scripture and develop a way of life according to it reverberated for many generations. John Calvin, as a young man studying in Paris, stayed with Etienne de LaForge, a Waldensian cloth merchant who became an important influence. ${ }^{111}$ Early Moravians, the group that will be described next, were "an important catalyst in the Protestant missionary movement [that] included some remnants of the Waldensians" as well. ${ }^{112}$

\section{The Moravians}

During the eighteenth century Waldensians found refuge from persecution in France and Italy and in the central European regions of Bohemia and Moravia. The

\footnotetext{
${ }^{110}$ The theme of Nobla Leyçon, the most famous and frequently read community poem, was that "the man called for salvation operates of his own free will; it is up to him to answer the call addressed to him. But time is short, for the end of the world is drawing nearer. In this dramatic and sometimes apocalyptic atmosphere made up of both overwhelming anguish and rapturous hope, everyone has a mission to fill in the place accorded to them in the community." Audisio, The Waldensian Dissent, 153.

111“"The grand principle maintained by these reformers - the same that had been held by the Waldensians, by Wycliffe, by John Huss, by Luther, Zwingli, and those who united with them - was the infallible authority of the Holy Scriptures as a rule of faith and practice. They denied the right of popes, councils, Fathers, and kings, to control the conscience in matters of religion. The Bible was their authority, and by its teaching they tested all doctrines and all claims." Ellen Gould White, The Great Controversy between Christ and Satan, 11th ed. (Mountain View, CA: Pacific Press, 1888), 248.

${ }^{112}$ Pierson, The Dynamics of Christian Mission, 113.
} 
Moravians, a small religious group of German Pietist orientation and inspired by the Waldensians, were founded by Nicolas von Zinzendorf and became a significant expression of Christianity. Jacques Blocher and Jacques Blandenier call the Moravian Brethren of Herrnhut "one of the greatest missionary revivals in Protestant history" and "the most important missionary efforts of the eighteenth century." 113

\section{Context}

During the seventeenth century the fierce persecution of the Counter-Reformation reached Moravia. In order to survive, small groups of people fled to the mountains and escaped to Saxony. In 1722, one of those groups, led by David Christian, met Count Zinzendorf, an "apparently fortuitous event" that gave birth to the church and the mission of the Moravian Brethren. ${ }^{114}$

Zinzendorf was raised in a Lutheran family influenced by Pietism. At Halle, while going to school, he learned about the mission of Tranquebar and other initiatives in India. Inspired by those stories, Zinzendorf, with a group of friends, founded the Order of the Grain of Mustard Seed with the purpose of preaching the gospel to Jews and pagans, and "to carry the gospel to those beyond the sea." 115 Zinzendorf was sent to the University of Wittenberg to study law, but his dream of dedicating his life to the service of God was never forgotten.

A milestone in Zinzendorf's spiritual journey happened while touring the art

\footnotetext{
${ }^{113}$ Blocher and Blandenier, The Evangelization of the World, 258, 263.

${ }^{114}$ Ibid., 263. The Moravian Brethren began in the context of the Lutheran mission to Greenland and the visionary leadership of Hans Egede and his family.

${ }^{115}$ Paul E. Pierson, "Moravian Missions," in Evangelical Dictionary of World Missions, ed. A. Scott Moreau et al. (Grand Rapids, MI: Baker Books, 2000), p. 660.
} 
gallery of the prince elector at Dusseldorf. He came across a painting by Domenico Fett that portrayed Jesus before Pilate. The following inscription was part of the work: "I have suffered this for you, what will you do for me?" After getting married, during his honeymoon, he met Moravian refugees and "decided to welcome and accommodate them on his lands by founding the village of Herrnhut, which means 'in the keeping of God." "116 By 1727 there were six hundred people in that community.

The objective of the Moravian community was "to provide Christian nurture for its members." The key element to accomplish their goal was a system of groups called choirs and formed according to age, sex, and marital status. People met daily for "mutual encouragement, sharing, confession, prayer, and discipline.” Also according to Spickard and Cragg, Herrnhut "consisted of 200 family houses, a single brethren house, a single sisters house, and a children's boarding house that was especially for the care of children whose parents were off in the mission field." 117 One of the most widely known spiritual features of that community was their prayer watch that began on August 27, 1727, two weeks after the group experienced its Pentecost, with twenty-four men and twenty-four women. Over time more people participated in the prayer watch rotation of seven days a week and twenty-four hours a day that lasted for over a hundred years and fostered a strong concern for world missions. ${ }^{118}$ Two other practices shaped the spirituality of the Moravians: Zinzendorf started a tradition of choosing a daily "Scripture watchword" for

\footnotetext{
${ }^{116}$ Blocher and Blandenier, The Evangelization of the World, 264.

${ }^{117}$ Spickard and Cragg, A Global History of Christians, 245.

${ }^{118}$ Pierson, “Moravian Missions,” p. 660. See also Blocher and Blandenier, 278.
} 
everyone's focus and he began to compose hymns to be part of their daily devotions, which "distinguished Moravian spirituality from that of most other churches of the time." 119

\section{Way of Living and Mission}

The foundation of Moravian piety was "the contemplation of the suffering of the Lamb who was sacrificed for the lost," which evidenced the need to dedicate themselves to their Savior, and which became the source of their missionary enthusiasm. "The Cross was not simply for them an orthodox doctrine, but an example of love to emulate." 120

Three major characteristics stand out in the Moravian mission: massive mobilization, identification with the local people, and communal responsibility. First, the Moravians mobilized in a way that reached the world in an unprecedented way. Missionaries worked in Greenland, North America, Jamaica and other islands in the Caribbean, South America, the West Coast of Africa, Ethiopia, Algeria, South Africa, Persia, Mongolia, and Ceylon - they were truly a world-wide mission. ${ }^{121}$ In 1832 , after a hundred years of Moravian mission, not every outreach effort had been a success. "Some of these efforts, however, were ephemeral, especially because of the high mortality rate of the missionaries. Others resulted in failure because of the negative reaction of the local populations, among whom no church could be established." ${ }^{22}$ Nonetheless, Moravians

\footnotetext{
${ }^{119}$ Spickard and Cragg, A Global History of Christians, 246.

${ }^{120}$ Blocher and Blandenier, The Evangelization of the World, 279.

${ }^{121}$ Pierson, "Moravian Missions."

${ }^{122}$ Blocher and Blandenier, The Evangelization of the World, 269, 275.
} 
had baptized 44,757 people. In 1882, two thousand Moravian missionaries had been sent into the world, which represented one missionary for every ninety-two members. ${ }^{123}$ The small community at Herrnhut provided over half the Protestant missionaries in the eighteenth century. ${ }^{124}$ Second, Moravians intentionally identified with the local people wherever they went. For example, in 1734, the first Moravians arrived in North America as immigrants and soon established villages to work with the Indians. This testimony about David Zeisberger (1721-1808), a missionary in North America who worked among the Iroquois and Delaware Indians, illustrates that point.

He was completely identified with the Indian tribes in whose midst he lived, surrounded by numerous converts. The dauntless courage he demonstrated in defending his Indian brothers won him the respect even of his bitterest enemies. Yet it is largely his linguistic work on the Indian languages that has prevented his name from being completely lost in the forgotten pages of history. ${ }^{125}$

Everywhere Moravians went "they taught slaves to read, cared for widows and orphans, nursed the sick, and translated the Scriptures and other Christian literature into many languages. They encouraged converts to become teachers and elders. ${ }^{.126}$ Finally, the Moravians from the beginning were organized into communities. Although pietism emphasized personal religion, the Moravians developed a way of living in Christian communities. ${ }^{127}$ Pierson points out that they studied medicine, geography, and languages,

\footnotetext{
123“'As a result of their work in the Danish Antilles, in 1757, after 25 years of activity, ninety-two missionaries (sixty-two men and thirty women) had come from Europe and more than 1,400 people had been baptized." Blocher and Blandenier, The Evangelization of the World, 268, 276.

${ }^{124}$ Pierson, "Moravian Missions."

${ }^{125}$ Blocher and Blandenier, The Evangelization of the World, 273.

${ }^{126}$ Pierson, "Moravian Missions."

${ }^{127}$ Spickard and Cragg, A Global History of Christians, 244.
} 
and, when they were sent out, their call was always validated by the community. ${ }^{128}$ Moravians spread that way of living everywhere they went and "from the very beginning, the Brethren were anxious to train their Christian converts and give them church tasks to perform." Because of that communal pattern of mission, it is said that they "were the first to envision mission, not as an individual or government-sponsored enterprise, but as a task for which the whole Christian community must feel responsible." 129 The Moravians were able to embody the character of Christianity that was taught by Jesus and practiced by early Christians.

An objective evaluation by Blocher and Blandenier pointed out three shortcomings in spite of the Moravian missionary dedication: (1) the lack of a comprehensive missionary strategy, (2) the lack of organization of the work, and (3) the lack of a training program for missionaries. ${ }^{130}$ Moravians believed that their settlements were "proved seminaries" for missionaries and rejected establishing a separate training school. ${ }^{131}$ Nonetheless, one is left to wonder about the relation of those deficiencies, and as Paul Pierson mentions, the over fifty adults and children who died in the first few years of their mission to the West Indies and Surinam, the hostility and opposition from

${ }^{128}$ Pierson, "Moravian Missions."

${ }^{129}$ Blocher and Blandenier, The Evangelization of the World, 268.

${ }^{130}$ Ibid., 278.

${ }^{131}$ Richard Tiplady, "Moravian Community, Spirituality, and Mission," in Global Missiology for the 21st Century: The Iguassu Dialogue, ed. William D. Taylor (Grand Rapids, MI: Baker Academic, 2000), 504. 
the planters and clergy, and the starvation, sickness and hostility by the people in Greenland. ${ }^{132}$

One of the Greatest Missionary Revivals in Protestant History

The Moravians were determined to emulate Christ's teaching and example during the seventeenth and eighteenth centuries. Their contact with Scripture inspired them as they read of the sacrifice of Jesus and the dedication of the early Christians. These were the factors that led them to develop the Moravian movement.

Their Christian movement was characterized by many of the same patterns found in the early Christians and Waldensians. Their burning conviction about the gospel led many of them to different parts of the world in a time when travelling was very challenging. Their high moral standards highlighted their way of living and their relations with slaves, widows, and orphans were not common to that age. Their sense of belonging was better illustrated by their own designation as brethren while the dynamic leadership of the movement was reflected in the participation of lay people in missionary initiatives. Their tenacious faith was evident in their endurance of hardships in the mission field. They practiced baptism and the Lord's Supper as part of a very worshipful routine that also included many hymns. Once again, the Moravian way of living closely imitated the early nature of true Christianity as a missionary movement. "Their pattern of life commended the gospel and consequently won many. They were not to seek glory for themselves. The missionary was to be content to suffer, die, and be forgotten."

\footnotetext{
${ }^{132}$ Pierson, "Moravian Missions."

${ }^{133}$ Pierson, "Moravian Missions."
} 
The Moravians influenced the development of Christianity in different ways. John Wesley, for example, was influenced by his direct contact with them. ${ }^{134}$

John and Charles Wesley, after being ordained to the ministry, were sent on a mission to America. On board the ship was a company of Moravians. Violent storms were encountered on the passage, and John Wesley, brought face to face with death, felt that he had not the assurance of peace with God. But the Germans, on the contrary, manifested a calmness and trust to which he was a stranger. ${ }^{135}$

In the nineteenth and twentieth centuries, the renewed interest in world missions is owed to some extent to the Moravians. Pierson points out that they were the first ones to recognize their obligation to the Jews and that many missionary societies resulted from their influence, such as The Basel and Leipzig Missionary Societies, the Methodist Missionary Enterprise, and the London Missionary Society. ${ }^{136}$ Another example of the Moravian influence is the journal Periodical Accounts that strongly influenced a then young Baptist minister, William Carey, who is considered the father of modern evangelical missions. ${ }^{137}$

\section{True Christian Missionary Movements throughout History}

Since Jesus ascended into heaven, His followers have sought to live out His teachings, follow His example, and make disciples in different contexts and times. Christian movements, however, reproduced the character of that original Christianity in varying degrees. Certainly not every denominated Christian expression in history has done well. The early Christians, the Waldensians, and the Moravians were selected as

\footnotetext{
${ }^{134}$ Spickard and Cragg, A Global History of Christians, 246.

${ }^{135}$ White, The Great Controversy, 254.

${ }^{136}$ Pierson, "Moravian Missions."

${ }^{137}$ Blocher and Blandenier, The Evangelization of the World, 279.
} 
examples of expressions that developed characteristics very close to the original model. They are examples of movements that were formed with the intention of restoring and preserving the true nature of Christianity. Because of that focus, those expressions became remarkable for their influence and impact on their world.

After these limited descriptions and focused analysis of these groups, it seems clear that Christianity for the early Christians, the Waldensians, and the Moravians was a way of living that embraced every aspect of their lives. That way of living based on the teachings and example of Jesus, reached out to others around them, who in turn became part of their groups that formed on-going missionary movements. More specifically a pattern emerged with eight common elements of the character of those Christian movements in their connection with Jesus Christ. They demonstrated (1) a burning conviction, (2) high moral standards, (3) a strong sense of belonging, (4) a tenacious faith, (5) dynamic leadership, (6) celebration of baptism and the Lord's Supper, (7) a focus on worship, and (8) an eschatological thrust. Those values took different forms and were translated into different customs and habits in each time and place. Nonetheless, they resulted in Christian movements that followed very closely the original character of Christianity. Other expressions of Christianity in history that possibly shared similar characteristics were the Celtic movement, ${ }^{138}$ Methodism, ${ }^{139}$ and Adventism. More recently, the initial phase of Pentecostalism and the underground church in China seem to

\footnotetext{
${ }^{138}$ For a provocative analysis of the missionary zeal of the Celtic movement, see George G. Hunter III, The Celtic Way of Evangelism: How Christianity Can Reach the West ... Again, 10th anniversary rev. and exp. ed. (Nashville, TN: Abingdon Press, 2010).

${ }^{139} \mathrm{By} 1850$, less than one hundred years, the movement claimed the allegiance of 34 percent of the population of England. Addison, Movements That Change the World, 59.
} 
also fall in the same category. ${ }^{140}$

In the New Testament, one finds accounts, including positive and negative happenings, of innovative groups of followers of Jesus in the first century who followed the Spirit's guidance to take the Gospel everywhere. They became a model for other Christians. ${ }^{141}$ The Waldensians emerged during a time of little access to the Scriptures and when most people in society showed little interest in caring for people in need. Their zeal for the Lord and their bold witnessing were not only influential during their time but became an important link to the Reformation. After a period when Protestant missions were nonexistent, the Moravians were influential in restoring the ethos of Christian missionary movements. They became the precursors of a surge in Protestant missions that would "profoundly alter the history of Christianity, making it a world religion."142

\footnotetext{
${ }^{140}$ Hirsch, The Forgotten Ways, 20.

${ }^{141}$ Drane, Introducing the New Testament, 9.

${ }^{142}$ Blocher and Blandenier, The Evangelization of the World, 280.
} 


\section{CHAPTER 4}

\section{PRESENT GLOBAL CHRISTIANITY: BEING IN THIS WORLD IN THE TWENTY-FIRST CENTURY}

The true nature of Christianity as a missionary movement has been reflected in its expressions throughout history, as pointed out in the previous chapter. In each case the challenge has been to rescue the essence of Christ's teachings and express it in each new context. For two thousand years Christianity has expanded geographically, and that expansion was the result of many factors. It was not only the consequence of, in many ways, unfortunate instances such as the Constantinian union between church and state, the crusades, European colonization, and the spread of Western culture, but especially the work of faithful witnessing by Christians who engaged their different contexts throughout time in order to introduce Jesus to people. Considering the global context one is led to realize that unprecedented changes that have happened since World War II in the political, economic, technological, religious, and social dimensions of life. This section will offer snapshots of the global contexts and expressions of Christianity, without intending to be exhaustive, that compose the panorama of present global Christianity.

\section{Context}

In order to better understand the context which today's Christianity faces, this section will include a brief description of the major interconnected philosophical, social, and religious aspects that form present-day reality. 


\section{Philosophical Context}

Today's philosophical current, often identified as postmodernity, became more prominent in the 1980s. This intellectual mood ${ }^{1}$ and its cultural expressions that are becoming increasingly prevalent in contemporary society are characterized by disillusionment with claims about certainty and truth, and lacks confidence in systems and institutions. Postmoderns value intuition, subjectivity in judgments, and personal perceptions of truth. Thus, the emphasis on non-individualistic models and non-rational dimensions of truth lead many to see the world holistically, instead of engaging an overarching explanation of reality (a metanarrative). ${ }^{2}$

This is seen as a reaction to the modern era and the Enlightenment of the seventeenth and eighteenth centuries that developed a rationalistic and optimistic scientific approach. Postmodernism marks the end of the metanarrative, science, and the objective world that was known before. As a cultural phenomenon, the central characteristic of postmodernism is pluralism, and it has found expression in architecture, art, theater, fiction, movies, television, and music, all which helped disseminate postmodernism. A lack of a positive outlook on life has also shaped an attitude that seeks satisfaction through hedonism and materialism, often identified as a consumerist lifestyle. " ${ }^{3}$ "Lately, both secular and Christian thinkers have questioned the capacity of

${ }^{1}$ Stanley J. Grenz, A Primer on Postmodernism (Grand Rapids, MI: W. B. Eerdmans, 1996), 12.

${ }^{2}$ Michael Pocock, Gailyn Van Rheenen, and Douglas McConnell, The Changing Face of World Missions: Engaging Contemporary Issues and Trends (Encountering Mission) (Grand Rapids, MI: Baker Academic, 2005), 106, 109.

${ }^{3}$ Samuel Escobar, "The Global Scenario at the Turn of the Century" in Global Missiology for the 21st Century: The Iguassu Dialogue, ed. William D. Taylor (Grand Rapids, MI: Baker Academic, 2000), 35 . 
modernity to address the deepest issues of humanity."4

\section{Social Context}

Two major trends have shaped the social context of Christianity in the twenty-first century: globalization and urbanization — both with demographic implications. In general, these aspects have resulted in both positive and negative effects. An overview of those two influences will help create the overall picture of society.

\section{Globalization}

The phenomenon of globalization has accelerated and intensified the exchanges between peoples around the world. Although people have always engaged in trade, conquest, and religious expansion, the new reality of globalization is a consequence of human advancements that has created a world with new patterns of interconnectivity. There is intense and varied offering of ideas, goods, and power through channels of communication, technologies, and travel. Since globalization is not a "one-way street," through those interactions peoples and cultures are continuously shaped at an accelerating rate.

The free-market economic system is one of the foundational elements responsible for globalization. The expansion of global business has brought industrialization to many agrarian cultures. This trend has brought new possibilities of acquiring wealth in the majority world, but has also victimized communities that were exploited in the process. Furthermore, if, on the one hand, industrialization has tended to homogenize cultures

${ }^{4}$ Pocock, Van Rheenen, and McConnell, 107. 
because of its standardization practices, on the other hand, cultural exchange has produced a multiculturalism that maintains a symbiotic relation with globalization.

New communication technologies have fostered rapid global exchange of information, providing huge amounts of data to people in every corner of the world. The internet has democraticized the access to information and learning by reducing distances, costs, and bureaucracy. ${ }^{5}$ That has been accompanied by developments in computing and mobile phones which continue to expand memory and processing capabilities. Positive consequences include applications of technology such as in the medical field, engineering, and energy research. One of the negative developments is cyber warfare.

A Barna Group study released in 2013 uncovered three trends that are influencing the way people access information: (1) "people feel modern life is accelerating and becoming more complex," (2) "people want to be culturally informed, but they are becoming accustomed to skimming content," and (3) "people are moving beyond mere facts and information, and are looking for holistic integration of faith and life. ${ }^{96}$ One of the groups that feel that life is growing increasingly complex is people of faith. Barna's research suggests that many aspects of these new trends have challenged people concerned with their spirituality and traditional faith values. Concerning the second trend, the majority (73\%) of practicing Christians say they want to stay informed about culture and trends (which is the same as the national American average). Finally, $90 \%$ of Millenials, more than any other generation, say they are searching for resources that can

\footnotetext{
${ }^{5}$ Pocock, Van Rheenen, and McConnell, The Changing Face of World Missions, 27, 29.

${ }^{6}$ Barna Group, “3 Trends Redefining the Information Age,” accessed October 27, 2013, https://www.barna.org/barna-update/culture/641-3-trends-redefining-the-information-age\#.Um2Afst3uUk.
} 
add meaning to their lives (two other significant groups who scored high in this area were adults who never married, 85\%, and parents with kids under 18 living at home, $80 \%$ ). Christians and many others are looking for ways faith addresses current challenges and opportunities. David Kinnaman, president of Barna Group, analyzes this research and suggests that this hunger for meaning is an opportunity for Christians. "Cultural interpretation and discernment can be a form of apologetic for faith. In a fast-paced culture of complexity, believers can assist the broader society, perhaps like the biblical examples of Daniel and Paul, by providing a sort of cultural analysis that leads to deeper understanding of meaning, the Church and Jesus."7

In addition to rising economic status and easy access to information, greater mobility is also increasingly available for many people. Fast and affordable air travel has given many the opportunity to travel around the world. "More North American church people than ever before have seen other cultures, learned directly from nationals overseas or on their U.S. campuses and jobs, and become more aware of global contexts simply because air travel has made the world smaller." ${ }^{\prime 8}$ Another aspect of the same trend is the growing migration of peoples. Since 1975 international migration has doubled. Over 200 million migrants live in countries different from their birth countries, and these migrating populations bring along their religious beliefs. ${ }^{9}$ Many conditions have fostered these movements, such as "increasing gaps, internationally, in quality of life; population

\footnotetext{
${ }^{7}$ Barna Group, "3 Trends.”
}

${ }^{8}$ Pocock, Van Rheenen, and McConnell, The Changing Face of World Missions, 26.

${ }^{9} \mathrm{~A}$ direct consequence of this migration to more developed countries is the flow of an estimated annual remittance of $\$ 62$ billion. Ibid., 47,49 . 
growth (and decline); climate change and ecological ruin; financial, educational and social opportunities; and upheaval, conflict and persecution."10

Some negative trends related to globalization have been connected to environmental problems such as climate change, loss of biodiversity, and clean water shortages. ${ }^{11}$ Other troubling trends include international terrorism and criminal empires. Examples of these activities include drug networks, smuggling of contraband, money laundering, and the control and extortion of politicians and business leaders. Recently the world has become more aware of human trafficking. Approximately 30 million people live in slavery, 800,000 people are smuggled across borders yearly (80\% of them are women and children), the majority of them for sexual exploitation. Jason Mandryk, who has worked on a survey of global Christianity, calls this "one of the great plights of our time," and concludes that "globalization probably benefits the wicked and corrupt as much as, if not more than, those with good intentions." 12

\section{Urbanization}

Another characteristic of the social context in the twenty-first century is the growth of cities around the world. A majority of the global population now live in cities. According to estimates, by 2025 sixty percent and by 2050 sixty-six percent will be in cities. According to those predictions, Sao Paulo, Brazil will be the fifth largest urban

\footnotetext{
${ }^{10}$ Jason Mandryk, Operation World, 7th ed. (Colorado Springs, CO: Biblica, 2010), 14.

${ }^{11}$ Richard Tiplady, One World or Many? The Impact of Globalisation on Mission, Globalization of Mission Series (Pasadena, CA: William Carey Library, 2003), 106-110.

${ }^{12}$ Mandryk, Operation World, 13.
} 
concentration in 2015 with 20.4 million people. Among the ten largest cities, only Tokyo is located in a traditionally advanced country as of 2015 . Although 80 percent of the largest urban conglomerates are in Asia and Latin America, African cities will hold a more significant share of this picture by 2050 when almost 66 percent of Africans will live in urban areas. ${ }^{13}$

One of the characteristics of cities in the twenty-first century is multi-ethnicity. As Pierson points out, "culture change in the urban centers is even more striking," which means that in order to understand that context, one has "to look not just at a geographical map of a country or a city, but also at a sociological map." ${ }^{\prime 14}$ Metropolitan cultures are also often characterized by apparent anonymity and loneliness, strong influence of materialism and secularism, open exposure to drugs, frequent breakdown of the family, and striking poverty. Another issue has been the difficulty of upgrading infrastructure to accommodate the increasing urban population, ${ }^{15}$ a factor that has led to even greater inequalities and lack of resources.

\section{Demographics}

During the last century world population experienced an enormous shift. People who lived in Europe, North America, and the former Soviet Union in 2000 represented only 18 percent of the world population, compared to 32 percent in 1900 . Africa and

\footnotetext{
${ }^{13}$ Philip Jenkins, The Next Christendom: The Coming of Global Christianity, The Future of Christianity Trilogy (New York: Oxford University Press, 2007), 107-108.

${ }^{14}$ Pierson, The Dynamics of Christian Mission, 343, 345.

${ }^{15}$ Mandryk, Operation World, 14.
} 
Latin America, on the other hand, represented 21 percent in 2000, up from only 13 percent in 1900. This shift has resulted from increased fertility rates and decreased mortality rates. Jenkins observes that "as Southern economies develop, their demographic patterns come to resemble those of the older industrial nations, and we already see a steadying or decline of fertility rates in much of the world." 16

Despite continuous scientific progress on prevention and treatment of diseases, HIV/AIDS continues to be threat to many families around the world. "Over 13 million children have lost one or both parents accounting for one-third of all orphans in the world. Today some 3 million children are living with HIV/AIDS." ${ }^{17}$ Older diseases still plaguing areas of our world include malaria and tuberculosis that are a special threat for those lacking sanitation, clean water, and those facing malnutrition and poverty. ${ }^{18}$ Other issues that affect the demographics of the world population are children at risk, the status of women, and the aging of the population.

\section{Religious Context}

As the world enters the second decade of the twenty-first century, developments in the philosophical and social contexts also helped shape the world's religious context. In this section, after introducing general trends, it is important to briefly consider the global Christian presence and the disappearing Christian center.

\footnotetext{
${ }^{16}$ Jenkins, The Next Christendom, 94-95. As of 2000, the eight largest nations of Sub-Saharan Africa had a combined population of about 400 million. The population also increased in Latin America and Asia during the second half of the twentieth century. Ibid., 97.

${ }^{17}$ Pocock, Van Rheenen, and McConnell, The Changing Face of World Missions, 51.

${ }^{18}$ Mandryk, Operation World, 13.
} 


\section{General Trends}

Enlightenment philosophers predicted the decline and death of religion, but that has not happened and religion continues to be an important part of society. In 2010 the percentage of the world that claims to be religious was around $88 \%$ (up from $80 \%$ in 1970, largely because of the resurgence of religion in China). ${ }^{19}$ In the last century, the religious context was transformed by the following five interconnected trends.

Religious Pluralism. New religions appeared everywhere, especially where there has been freedom of expression. ${ }^{20}$ The increasing growth and acceptance of a pluralistic ethos, which has "a set of assumptions and values that celebrates diversity of religious experience and expression as something good and healthy [and] is deeply suspicious of attempts to privilege one tradition or teaching as normative to all." Within that context, Christianity has come to be considered by many as just one more religious option. ${ }^{21}$

The Rise of Islam. As part of the growing pluralism, the last century witnessed the revitalization of the world religions, including Islam, Buddhism, Hinduism, ethnic religions, and animism. This has contributed to a sustained decline in the world's nonreligious population. ${ }^{22}$ The influence of Islam, the largest of those religions, is growing and spreading in the countries of North Africa, the Middle East, and Central

\footnotetext{
${ }^{19}$ Gina A. Bellofatto and Todd M. Johnson, "Key Findings of Christianity in Its Global Context, 1970-2020," International Bulletin of Missionary Research 37, no. 3 (2013): 157.

${ }^{20}$ Pocock, Van Rheenen, and McConnell, The Changing Face of World Missions, 81.

${ }^{21}$ Harold A. Netland, Encountering Religious Pluralism: The Challenge to Christian Faith \& Mission (Downers Grove, IL: InterVarsity Press, 2001), 4. The Baha'i religion, because of its syncretistic essence, is the most geographically widespread faith, second only to Christianity. Bellofatto and Johnson, 158.

${ }^{22}$ Bellofatto and Johnson, "Key Findings of Christianity, " 157.
} 
Asia. Besides high birthrates and migration, conversion has been a key factor for growth in West Africa, Indonesia, and the United States. In the past one hundred years, Islam has grown from $12.3 \%$ in $1900^{23}$ to $23.2 \%$ (1.6 billion people with a median age of 23 ) of the world population in 2010. According to a study by Pew Research released at the end of 2012, Muslims are a majority in 49 countries. The largest Muslim population is in Indonesia $(209,120,000)$ where they represent $87.2 \%$ of the population. In India, the country with the second largest Muslim population, there are $176,190,000$, which represent $14.4 \%$ of the population. ${ }^{24}$

Secularism. Another characteristic in the religious context in the West is the increasing separation between public life and faith. "Functions once performed by the church - marriage, education, health care, conflict resolution, funerals - are assumed by nonreligious institutions, which in turn dominate and define the public sector." 25

The Rise of the "Nones." Part of the same reality is what fuels the growth of the unchurched, also called "nones," and those seeking alternative spiritual paths. As Harold Taylor points out, the decline in church involvement can be partly explained by an increase in spiritual and religious experimentation, "sometimes by a return to preChristian Pagan religion, or by an 'amalgam' spirituality which draws on many different

\footnotetext{
${ }^{23}$ Mandryk, Operation World, 22.

${ }^{24}$ PewReserch, "Global Christainity-A Report on the Size and Distribution of the World's Christian Population," accessed November 13, 2013, http://www.pewforum.org/2011/12/19/globalchristianity-exec/.

${ }^{25}$ Netland, Encountering Religious Pluralism, 151.
} 
sources to provide a personalized 'Do-it-Yourself' religion." ${ }^{26}$ Religiously unaffiliated people are the third-largest "religious" group worldwide, behind Christians and Muslims. Roughly one-in-six people around the globe, $16.3 \%$, are religious "nones." The number of religiously unaffiliated people in China alone is more than twice the total population of the United States. About 700 million Chinese residents do not identify with a specific religious group. ${ }^{27}$

Technological Spirituality. Technology is reshaping personal spirituality, especially among younger generations such as Millenials (ages 18 to 29). The most common feature of this spirituality is the digital reading of Scripture (70\% of Christian Millenials, $30 \%$ of all Millenials). Other areas where technology impacts religious life include accessing online religious videos (54\% of practicing Christian Millenials, $31 \%$ of all Millenials), checking out a church, temple, or synagogue website (56\% of practicing Christian Millenials, 34\% of all Millenials), and searching on the Web for spiritual content (59\% of practicing Christians Millenials, $30 \%$ of all Millenials). Millenials also have a habit of seeking information from sermons online (38\% of practicing Millenials, $14 \%$ of all Millenials), engaging in online conversations about faith (40\% of practicing Millenials), and making online donations to a church or faith organization (39\% of practicing Millenials, $11 \%$ of all Millenials). ${ }^{28}$

\footnotetext{
${ }^{26}$ Harold Taylor, "Contextualized Mission in Church History," in Encountering New Religious Movements: A Holistic Evangelical Approach, ed. Irving Hexham, Stephen Rost, and John Morehead (Grand Rapids, MI: Kregel Academic \& Professional, 2004), 43.

${ }^{27}$ PewReserch, "Global Christainity.”

${ }^{28}$ Barna Group, “How Technology Is Changing Millenial Faith,” accessed October 27, 2013, https://www.barna.org/barna-update/millennials/640-how-technology-is-changing-millennialfaith\#.Um2IKMt3uUk.
} 


\section{The Global Christian Presence}

Christianity has also been influenced by changing philosophical and social contexts. As mentioned in the introduction of the section about current global Christianity, a major characteristic of Christianity at the end of the twentieth century was its global presence. While it is not a majority religion in every part of the world, it is present in most places. Despite all types of threats such as religious wars, philosophical skepticism, and heresies, Christianity "emerged at the end of the century as the largest religion in the world." Furthermore, Neill points out that "in the twentieth century, for the first time, there was in the world a universal religion—-the Christian religion." ${ }^{29}$

According to a PewResearch study, in 2010 there were about 2.18 billion Christians in the world representing nearly a third of the global population. Christians were the majority in 157 countries and in four of the six regions of the world (Latin America and the Caribbean, North America, Europe, and sub-Saharan Africa). Christians are in the minority only in the Asia-Pacific region and the Middle East-North Africa region. ${ }^{30}$ There are fourteen countries with a Christian presence of less than one percent and another twenty-three with less than five percent. ${ }^{31}$ Jenkins estimate that the largest Christian communities in 2050 will be in the U.S. (330 million), Brazil (195 million),

${ }^{29}$ Neill, Christian Missions, 473. Even though Neill's assessment may be gleaner than the reality, especially in terms of significant Christian presence around the world, he also mentions that "some hostile critics argued that this vast Christian expansion was nothing but the accompaniment, and hangover, of European power, military and industrial, in Asia and Africa and would certainly decline, fail, and perhaps vanish as Europe declines and European influence in Asia and Africa returned to nothing." If that seemed to be the path of history in Neill's days, it certainly did not turn out that way everywhere. Africa is probably the best example of Christian expansion despite the absence of European ruling. Ibid.

\footnotetext{
${ }^{30}$ PewReserch, "Global Christainity."

${ }^{31}$ Mandryk, Operation World, 21.
} 
Mexico (145 million), the Phillipines (145 million), Nigeria (123 million), and the D. R. Congo (121 million) —all with over 100 million Christians. ${ }^{32}$

The evangelical expression of Christianity has been responsible for most of the growth. In Latin America, for example, evangelicals have grown from 50,000 (1900) to 64 million (1997), from one percent of the population (1930) to twelve to fifteen percent (1999). ${ }^{33}$ It is estimated that 8,000 Latin Americans switch from the Catholic Church to Evangelicalism every day. ${ }^{34}$ Despite that impressive growth, it should be noted that the percentage of Christians in South America has dropped from $95.1 \%$ in 1970 to $91.9 \%$ in 2010 and is expected to reach $91.4 \%$ by 2020 due to increases in the percentage of Spiritists (from 1.4\% in 1970 to expected 2.6\% in 2020) and Agnostics (from 1.2\% in 1970 to expected $3.5 \%$ in 2020). ${ }^{35}$

\section{The Southern Christian Center}

While Christianity has always had a geographic center, today it has spread in such a way that it cannot be identified with North America or Western Europe as in the past five centuries. In fact "most Christians today live and thrive outside the former boundaries of Western Christendom.." ${ }^{36}$ In 1970, 41.3 percent of all Christians worldwide

\footnotetext{
${ }^{32}$ Jenkins, The Next Christendom, 104.

${ }^{33}$ Pocock, Van Rheenen, and McConnell, The Changing Face of World Missions, 86.

${ }^{34}$ Pedro C. Moreno, "Evangelical Churches," in Religious Freedom and Evangelization in Latin America: The Challenge of Religious Pluralism, ed. Paul E. Sigmund (Maryknoll, NY: Orbis Books, 1999), 50 .

${ }^{35}$ Center for the Study of Global Christianity, Christianity in Its Global Context, 1970-2020: Society, Religion, and Mission (South Hamilton, MA: Gordon Conwell Theological Seminary, 2013), 6061.

${ }^{36}$ Pocock, Van Rheenen, and McConnell, The Changing Face of World Missions, 132. "Founded in the Near East, Christianity for its first thousand years was stronger in Asia and North Africa than in
} 
were from Africa, Asia, or Latin America. By 2020 this number is expected to be 64.7 percent. $^{37}$

Over the last century or so, massive secularization has seriously reduced the population of European Christians, whether we judge 'Christianity' by general selfdefinition or else demand evidence of practice and commitment. Rates of church membership and religious participation have been declining precipitously in a longterm trend that shows no signs of slowing. ${ }^{38}$

Over the last hundred years the situation changed even more and "the center of gravity" of Christianity has moved to the southern hemisphere, between Africa and Latin America. Jenkins predicts the consolidation of that scenario in coming years. There is a large group of Christians in many of the fastest growing countries, which combined with conversions and the low birth rates of the traditionally Christian countries will contribute to the shifting of Christianity. As Jenkins suggests, if one wants "to visualize a 'typical' contemporary Christian, [one] should think of a woman living in a village in Nigeria, or in a Brazilian favela." Furthermore, he views that as the new norm, since "far from being an export of the capitalist West, a vestige of Euro-American imperialism, Christianity is now rooted in the Third World, and the religion's future lies in the global South."39 Majority world Christians were 16.7 percent of all Christians in 1900 and 59.4 percent in $2000 .^{40}$

Europe, and only after about 1400 did Europe (and Europeanized North America) decisively become the Christian heartland." Jenkins, The Next Christendom, 19.

${ }^{37}$ Bellofatto and Johnson, "Key Findings of Christianity," 158.

${ }^{38}$ Jenkins, The Next Christendom, 109.

${ }^{39}$ Ibid., xi, 2.

${ }^{40}$ Patrick Johnstone and Jason Mandryk, Operation World: When We Pray God Works, 21st Century ed. (Waynesboro, GA: Paternoster USA, 2001), 5. 


\section{Way of Living and Mission}

A picture of present global Christianity would be incomplete without

considerations about how Christians have interacted with their context while seeking to live out the teachings of Jesus Christ and reproduce His example. This section will focus on the way of living of a majority of world Christians and the unfinished task of Christian mission.

\section{Majority World Christians}

Present day Christianity is not only a matter of geography. The nature of this new majority and their faith includes a tendency to be more committed in terms of belief and practice. In general, majority world expressions of Christianity are very enthusiastic, far more conservative in beliefs and moral teachings, much more concerned with the workings of the supernatural (through prophecy, visions, and healing), and with personal salvation. "They take the Bible seriously.... They believe that the world of the apostles is a present reality."41

Another aspect of these newer expressions, related to their vital and dynamic expressions and partly responsible for their development, is their ability to adapt to local "traditions and thought-patterns." The result is African Christianity, Asian Christianity, and so on. ${ }^{42}$ As Smith points out, "at the very point in the mid-twentieth century at which

${ }^{41}$ Addison, Movements That Change the World, 51; Jenkins, The Next Christendom, 125.

${ }^{42}$ Jenkins, The Next Christendom, 156. "Non-Western forms of Christianity existed long before the modern era although they have generally been neglected in studies of church history written from an European perspective. . . . Likewise, there has been an unbroken Christian presence on the African continent stretching back across many centuries and the symbolic importance of such traditions in modern times is reflected in the fact that large numbers of independent African congregations scattered across the south and west of the continent have affirmed their African identity by describing themselves as 'Ethiopian' churches. In this way, modern African Christians have signaled their awareness of a Christian 
the colonial empires were receding, indigenous forms of Christianity displayed

considerable growth, demonstrating the extent to which the faith had put down deep roots in the soils of local cultures and languages."43

It has been observed that there is a pattern since these expressions share similar experiences of growth and development, inculturation and colonial heritage issues, and passionate enthusiasm for mission and evangelism. ${ }^{44}$ To Jenkins, these churches follow the classic aspects of a sect as defined by sociology of religion terms in relation to leadership, worship style, and degree of commitment. Therefore, he suggests that the common factor among these expressions of Christianity is that, in most cases, they are new "mass popular movements" and consequently do not depend on biological growth.

While Western missions played a crucial role in the initial act of communicating the gospel across cultural and linguistic barriers, the key players in the spread of the faith have invariably been local Christians who were able to express their new religion in surprising and dynamic ways in contexts frequently marked by severe social and cultural crisis. ... In addition, an important contribution has come from the ministries of prophetic preachers and evangelists who spontaneously applied the faith to local situations, presenting Christ in ways that resonated with the felt needs of their own people and reaping huge harvests in the form of mass movements of converts on a scale that equals, and probably surpasses, previous revival movements in Christian history. ${ }^{45}$

Even in Europe and North America, where the majority of Christians have

tradition on this vast continent which long pre-dates colonization and stretches back to the earliest Christian centuries." David Smith, "Contemporary Christianity in the Non-Western World," in Introduction to World Religions, ed. Christopher H. Partridge (Minneapolis, MN: Fortress Press, 2005), 345.

${ }^{43}$ D. Smith, "Contemporary Christianity in the Non-Western World,” 344.

${ }^{44}$ Jenkins, The Next Christendom, 14.

${ }^{45}$ D. Smith, “Contemporary Christianity in the Non-Western World,” 345. 
embraced a prevalent nominalism, ${ }^{46}$ the most thriving expressions of Christianity are almost always part of newer ethnic communities. That phenomenon still has to pass the test of time, since "aside from the usual difficulties in assessing religious loyalties, there is also the issue of harmonization, of judging how far the children of immigrants will adopt the laxer and more 'modern' thought-ways of Europe." 47

In reference to the vitality of Latin American Christianity, historians Ondina and Justo Gonzalez comment that after being established in that region, local expressions of Christianity appeared beyond its original orthodox forms. "People—natives, criollos, Blacks, Whites, men, women, children, mystics, reformers, heretics, Catholics, traditional Protestants, Pentecostals — expressed and lived their faith in their own particular ways."48 There new expressions have influenced traditional Catholic cultures in such a way that today Protestants are creating, what Moreno calls, "a new understanding of reality, a 'new cultural ethos.',"49

Historically, Catholicism accommodated prevailing cultural norms so that popular theology reinforced traditional culture, frequently absorbing popular folk religious

46"'In many Christianized countries, most of the population need to be re-evangelized; living in the afterglow of a Christian heritage does not confer eternal salvation," Mandryk, Operation World, 22. David Smith points out that the "inescapable evidence of the vitality and growth of churches in Latin America ... has led to the conclusion that the secular experience of Europe, far from being the vanguard of a global trend, might actually be unusual and exceptional." Ibid., 346.

${ }^{47}$ Jenkins, The Next Christendom, 116.

${ }^{48}$ Ondina E. González and Justo L. González, Christianity in Latin America: A History (New York: Cambridge University Press, 2008), 300.

${ }^{49}$ Moreno, "Evangelical Churches," 62. There has been noted the same phenomenon in other regions, such as India. "They revolutionized India by preaching the gospel, winning people for Christ, discipling, establishing churches, igniting social changes and even influencing the Freedom Movement. These missionaries had much to do with building modern India and with developing a new ethos in the country through their many social endeavors." K. Rajendran, "Evangelical Missiology from India," in Global Missiology for the 21st Century: The Iguassu Dialogue, ed. William D. Taylor (Grand Rapids, MI: Baker Academic, 2000), 308. 
beliefs. Evangelicalism, by contrast, emphasizes a radical break with the traditional, frequently calling it demonic. ... Evangelicals have also broken down traditional social and racial boundaries so that rich and poor, educated and uneducated, unite, frequently holding hands and hugging one another. Thus, evangelical belief systems, conversion, and lifestyles are transforming how Latin Americans think and relate to one another. ${ }^{50}$

Among the trends in Latin American Christianity since World War II, as Spickard and Cragg note, the most important are the rise of liberation theology and the growth of Pentecostalism. "Central to liberation theology was a "preferential option for the poor and oppressed" "based on the understanding that "theology was not to be the product of mere contemplation; it was to spring up naturally from the strivings of human existence. One did not write theology or think theology; one did theology." The most complicated part of its development, however, was its emphasis on "the sin of oppressive structures and power relationships in society more than the sins of individuals." ${ }^{51}$ One of the most promising results of this theology within the Catholic Church was the creation of base ecclesial communities in slums and other poor neighborhoods. These small groups met to read the Bible, pray, sing, and talk about their struggles. "Out of such communities came spiritual revival, and also critical social analysis and plans for action that meshed with aims of liberation theology." ${ }^{52}$ Many of those groups did not last in face of fierce opposition in part from within the Catholic Church (including then influential conservative bishop Josef Ratzinger, later pope Benedict XVI), but also from politicians

\footnotetext{
${ }^{50}$ Pocock, Van Rheenen, and McConnell, The Changing Face of World Missions, 86.

${ }^{51}$ Spickard and Cragg, A Global History of Christians, 428-429.

${ }^{52}$ Ibid., 430.
} 
and theologians, who dismissed the movement for its strong emphasis on social liberation instead of individual evangelism.

Pentecostalism, born in the United States in the beginning of the twentieth century, has grown more rapidly in Latin America. Despite a resemblance with many forms of evangelicalism in its embrace of a literal biblicism and a strong Christology, its major distinct features stress an experiential Christianity related to the continuity of the charismatic gifts of healing, prophecy, and speaking in tongues, as well as an urgent missiology. Other characteristics include "a belief in supernatural recruitment," "a tendency towards legalism and sectarianism," "a lay movement," "an emphasis on music and worship," "an urban movement," and "a focus on church planting and stewardship." ${ }^{, 53}$ Finally, it appeals primarily to the poor to whom it promises liberation, power, and connectedness. Pentecostalism has also found ways to adapt to fit most cultures. ${ }^{54}$ Additional contributions Pentecostalism may have made to the larger Church include an emphasis on several aspects that had been neglected by most denominations, but some dangers have also been pointed out within Pentecostal groups, such as a quick conformation to surrounding culture, an exaggerated focus on experience, growing institutionalization, authoritarianism among its leaders, and a utilitarian prosperity gospel. $^{55}$

\footnotetext{
${ }^{53}$ Pierson, The Dynamics of Christian Mission, 311-313.

${ }^{54}$ Spickard and Cragg, A Global History of Christians, 434.

${ }^{55}$ Pierson, The Dynamics of Christian Mission, 313-314.
} 
Another important trend identified in the global South is a new dynamic in world missions called South-South, which involves missionaries from emerging churches in the southern hemisphere going to regions of Africa, Asia, or Latin America. "Although poorly studied, South-South evangelism represents one of the most impressive phenomena in contemporary Christianity." ${ }^{" 56}$

Thus, Christianity in Latin America at the end of the twentieth century and early in the twenty-first shows strong signs of vitality. ${ }^{57}$ As Gonzalez points out, one of the major developments of Christianity in Latin America during the last century "was that it became a protagonist of its own history.... [F]or the first time in its history, Latin American Christianity became an active participant in world Christianity, making its presence felt in various parts of the world." ${ }^{58}$

\section{The Unfinished Christian Mission}

Despite the expansion of Christianity and its new vibrant expressions especially in the southern hemisphere, the task of Christian mission remains an enormous challenge. Many people around the world still have not heard the name of Jesus Christ or had a fair chance to choose Him as their Lord and Savior. According to the model employed by the

\footnotetext{
${ }^{56}$ Jenkins, The Next Christendom, 14. Jenkins prophesies that this emergence and growth of Southern Christianity will become "the next christendom." "Given the lively scholarly activity and the flourishing spirituality in the global South, a period of mutual discovery is inevitable. When it beginswhen, not if - the interaction should launch a revolutionary new era in world religion. Even though many see the process of globalization as yet another form of American imperialism, it would be ironic if an early consequence was a growing sense of identity between Southern Christians. And once that axis is established, we really would be speaking of a new Christendom, based in the Southern Hemisphere." Jenkins, The Next Christendom, 14.

${ }^{57}$ González and González, Christianity in Latin America, 300.

${ }^{58}$ Ibid., 302.
} 
World Christian Database in 2010, out of 13,461 people groups, 4,402 were in the unreached category (less than 50\% evangelized) as part of the total of 2.04 billion unevangelized people. Following another model that is used by the Joshua Project, there are a total of 16,585 people groups, with 7,165 unevangelized (less than $2 \%$ evangelical and less than 5\% Christian adherents), representing 2.88 billion people. Despite the different numbers, the reality of the unfinished task is clearly portrayed. ${ }^{59}$

Christians are engaged in God's mission around the world. In 2010, 400,000 international missionaries were sent (not counting those working in their home countries). Three of the ten countries sending the most missionaries were from the majority world: Brazil, South Korea, and India. South Africa, the Philippines, Mexico, China, Colombia, and Nigeria were also among the top twenty sending countries. Majority world missionaries often have a greater understanding of the need for mission and social justice to go hand-in-hand, especially to fight poverty and hunger. However, only $19 \%$ of the entire world population, not counting Christians, personally know a Christian from any tradition. That percentage is even lower (14\%) among Muslims, Hindus, and Buddhists. ${ }^{60}$ Changes in the philosophical, social, and religious contexts have influenced the wider cultures as well as how Christians pursue the missionary task. As mentioned in the previous sections, the changes of the last five decades were so significant that they have given rise to a new epoch in which many trends could be identified as both threats and opportunities.

\footnotetext{
${ }^{59}$ Center for the Study of Global Christianity, Christianity in Its Global Context, 81 .

${ }^{60}$ Ibid., 8, 76-78.
} 
Besides the challenge of reaching a large number of people and their respective people groups around the world, the current context has posed new challenges to missionary activity. On the one hand, postmodernity, the defining influence in the philosophical context has threatened many paradigms of the church and its mission. Probably the most significant is its fostering of religious pluralism and relativism that seriously affects the church's claim to universal truth. "The fragmentation of Western culture splits Christianity's historical alliance with that culture, while also giving rise to histories that implicate Christianity in a wide range of the culture's ills — racial conflicts, the ecological crisis, battles over sexuality and gender" 61 The Protestant mission movement began in the modern era. Many missionaries found the findings of modern science as reasonable, but a careful analyses concludes that both modernity and postmodernity present enormous challenges to God's mission. "Truth claims about transcendent issues in the realm of God and spirituality are not easily demonstrated by modern, data-based, rationalistic methods. However, absolute truth also cannot be found through the more postmodern emphasis on intuition and subjectivity." ${ }^{62}$ On the other hand, postmoderns are more inclined to allow people to adopt different ways of living and have different stories. They are especially open to a gospel that promotes community, that embraces the whole experience of life, yet is not anti-intellectual, that is not dualistic, and that emphasizes a commitment to a cause. ${ }^{63}$

\footnotetext{
${ }^{61}$ Curtis Chang, Engaging Unbelief: A Captivating Strategy from Augustine \& Aquinas (Downers Grove, IL: InterVarsity Press, 2000), 20.

${ }^{62}$ Pocock, Van Rheenen, and McConnell, The Changing Face of World Missions, 108.

${ }^{63}$ Grenz, A Primer on Postmodernism, 167-174. Spickard and Cragg point out a similarity between the first century context and today, since "the spirit of age, like that of our own era, instinctively rejected
} 
Recent contextual factors have again influenced missionary activity by posing threats and offering opportunities. On the one hand, the wide-spread internet accessibility has exposed peoples to arguments against Christianity while on the other hand, nonChristians can investigate the Bible and interact with Christians without exposing themselves unnecessarily to persecution. Missionaries have never had as much information available about their destination and people-group before arriving in the field. Evangelism, discipleship, and leadership training are other resources that are much more available because of the internet. ${ }^{64}$

Migration of people has also created challenges and opportunities. Migration has created more pluralistic contexts and has mixed adherents of different religions in neighborhoods that used to be fairly homogeneous. Migrations of people also have given numerous opportunities for missionary expansion as migrants hold on to their worldview and share their faith in their new contexts. ${ }^{65}$

The unfinished task of mission and current, contextual challenges have raised additional questions concerning the process of mission.

1. How does mission maintain a clear witness to the uniqueness of Christ in an increasing pluralistic postmodern world?

claims of absolute truth. At the same time, this attitude made them more willing to listen to new ideas. Luke in Acts 17:21 notes how the Athenians especially like to hear about anything new, including the good news of Jesus." Spickard and Cragg, A Global History of Christians, 77.

${ }^{64}$ Pocock, Van Rheenen, and McConnell, The Changing Face of World Mission, 27.

${ }^{65}$ Jehu J. Hanciles, "Migration and Mission: Some Implications for the Twenty-First-Century Church," International Bulletin of Missionary Research 27, no. 4 (2003): 146. 
2. How do God's witnesses sustain the centrality of the Scriptures in an increasingly syncretistic society that embraces a health and wealth worldview and that looks at issues of gender and sexuality in non-biblical ways?

3. In face of a globalized society, the church should reflect and at the same time question every particular context. Should the church champion multiethnic churches? How should the church deal with the diaspora of people groups? Should each group be focused on separately, or should there be an emphasis right from the start on multiethnic evangelism?

4. How should local churches foster a missionary ethos that mobilizes the laity both in traditional and emerging congregations?

5. How should leaders, men and women, be developed at local congregations and at seminaries with special consideration to contexts where the majority of the members is composed of youth?

6. In regions where the church has been growing faster, is it possible to disciple new believers in order for them to have their worldview and lifestyle shaped by a relationship with God and in accordance to Scripture?

7. How could Christianity genuinely have an outward emphasis on outreach, evangelism, mission, and community engagement?

8. The current social context has relied on a numerical language that is typical of the Western traditional business world. Is it possible to adopt a non-numerical language to describe the true nature of the experience of the gospel? 
9. As globalization makes it possible for much more interaction, how should missionaries refine their understanding about critical contextualization in order for them to allow for Christianity to take root in the new culture and avoid exporting distortions?

10. Will the levels of persecution continue to rise in contexts where Christianity does not stand as the majority? ${ }^{66}$

11. How should the church maintain a holistic emphasis in the definition of what it means to be human so that needs are taken into consideration and transformation is experienced in every area of individual and collective life, be it in a rural or urban context?

12. How can the vitality of Christians' spiritual lives especially in the traditional Christian areas of the globe be ignited ${ }^{67}$

\section{A Twenty-First Century Missionary Movement That Is a True Expression of Original Christianity?}

This biblico-historical investigation about the character of Christian movements began with a description of the context in which Christianity first developed. It explored the mission of Jesus, including His teachings, ministry, and commission. Jesus was born in Palestine, under Roman rule and was influenced by pan-Hellenic culture-a mix that resulted from historical developments. The religious identity of the Palestinians,

\footnotetext{
${ }^{66}$ For updated statistics on the persecution of Christians around the world, see Tieszen, Charles. "Persecution of Christians in the World Today: Current Trends and Their Implications for the Global Church." Lausanne Global Analysis 4, no. 2 (September 2013): 6-9. https://www.lausanne.org/docs/lga/ lausanne-global-analysis-2013-09.pdf.

${ }^{67}$ Some of these aspects are pointed out by Alex Araujo, "Globalization and World Evangelism," in Global Missiology for the 21st Century: The Iguassu Dialogue, ed. William D. Taylor (Grand Rapids, MI: Baker Academic, 2000), 62-64. Others are listed by Mandryk, Operation World, 16-18.
} 
however, was related to Second-temple Judaism, which developed within the history of the people of Israel. While monotheism, covenant, and eschatology summarize their worldview, their temple, land, and Torah were the concrete expressions that united them. Even internal revolts and divisions did not eliminate the vigor and zeal of sincere Jews that both continued to live in Palestine and spread to other land as part of the Diaspora. The Jewish worldview was essentially concerned with what one ought to do in relation to God. Their religion was a way of living or a way of being in the world.

A brief description of Jesus Christ and his mission, with special consideration of his message, ministry, and commission, makes it clear that Jesus Christ is the center of Christianity. His character, His life, His teachings, His work, and His followers have established the nature of this worldwide missionary movement. It is important to realize, however, that His mission was in continuity with much of His Jewish religious context and certainly in connection with the preparatory ministry of John the Baptist. Jesus was not just another prophet or master, but the promised Messiah, who came to inaugurate His kingdom. That was the focus of His mission. The ultimate revelation was that Jesus was humanity's Lord and Savior.

At the heart of Jesus's mission was His revelation of God and people's understanding about and relationship with him. The uniqueness of Jesus and His message could be seen in the impact on the lives of the people and the expansion of Christianity. The new followers not only had the spiritual aspects of their lives changed, but also their worldview and lifestyle. It was a way of living, a way of being in the world. 
This development and expansion of Christianity is much more complex than just a haphazard coincidence of social factors in the ancient world. ${ }^{68}$ After a limited description and specific analysis of each of them, it is clear that Christianity in every context was a way of living that embraced every aspect of their life. That way of living, based on the teachings and example of Jesus, reached others around them who became part of their groups forming a missionary movement. More specifically a pattern emerged with common elements or aspects of the character of those Christian movements in connection with Jesus Christ. These are the eight aspects: (1) a burning conviction, (2) high moral standards, (3) a strong sense of belonging, (4) a tenacious faith, (5) dynamic leadership, (6) celebration of baptism and the Lord's Supper, (7) a focus on worship, and (8) an eschatological thrust.

Since Jesus' death many people have claimed to follow Him and His teachings. Throughout history many expressions of that initial concept have developed. All those different groups claim some kind of root in what Christ did. Different understandings about Him and the Bible have originated different movements. For this study the Early Christians, the Waldensians, and the Moravians were selected. The patterns took different forms and became different customs and habits in each time and place. The application of those principles in different societies with different dynamics looked very different. However, those expressions of Christianity proved to have been the result of a conscious effort to reproduce the essential character of original Christianity as founded by Christ.

\footnotetext{
${ }^{68}$ Drane, Introducing the New Testament, 29.
} 
The specific way of living of God's people in those expressions formed Christian missionary movements.

In the beginning of the twenty-first century, Christianity has expanded geographically as a consequence of different factors, including the faithful witnessing of Christians who have engaged with different contexts in different times in order to introduce Jesus to people. From the beginning, as more and more people learned about Jesus, Christian movements expanded in every direction. Drane points out that "it was not among simple peasants on the shores of the inland Sea of Galilee that his teaching made its greatest impact. In a very short time after his death, his personality and his beliefs were having a profound effect in places far removed from the shores of Palestine," despite the obstacles of that context. ${ }^{69}$ A little over two thousand years later, Christianity has achieved a global presence. It is the first one, or perhaps the only one, to achieve that status. William Temple's famous remarks in 1942 as the Archbishop of Canterbury reflect that understanding. He classifies the worldwide expansion of Christianity as "the great new fact of our time."70

Considering Christianity as a global reality can make us see the whole religion in a radically new perspective, which is both startling and, often, uncomfortable. In fact, to adapt a phrase coined by theologian Marcus Borg, it is as if we are seeing Christianity again for the first time. In this encounter, we are forced to see the religion

\footnotetext{
${ }^{69}$ Drane, Introducing the New Testament, 110-12. Stephen Neill describes the Jewish social context in which Jesus lived as "anything but favourable to such a world-wide expansion." He mentions the animosity present in the relationship between Jews and their neighbors, the political unrest characterized by hopes of liberation from the Roman power and exaltation among the nations. Neill, A History of Christian Missions, 16.

${ }^{70}$ The Church Looks Forward (London, 1944), p. 2-3. See Neill, A History of Christian Missions,
} 15. 
not just for what it is but what it was in its origins - and what it is going to be in future. ${ }^{71}$

The new scenario of Christianity is not only a matter of geography. The nature of this new majority world Christianity presents a tendency to be more committed in terms of belief and practice than its predominantly North American and Western European versions. Despite the growth and expansion of Christianity, the task of mission remains unfinished. Between two and three billion people are unevangelized and less than $20 \%$ of religionists personally know a Christian. Besides, the world has gone through dramatic changes and is a different society in the beginning of the twenty-first century. The major consequence of those changes for mission is the fact that "in the post-Christendom situation, Christians cannot expect society to facilitate through social mechanisms the kind of life that abides by the qualities of Christian ethics." ${ }^{, 72}$

The unfinished task of mission and current, contextual challenges have raised concerns and needs in terms of the missiological process in Christianity. This is a different, but hopeful scenario. David Smith points out that "what makes the situation at the beginning of the twenty-first century so interesting is that we appear to be witnessing a rerun of this pattern in which Christianity thrives by means of missionary translation even as it experiences decline in its previous heartlands."73 The solution seems to lie beyond just increasing the number of missionaries sent, but includes an appropriate understanding of the nature of biblical Christian movements and the current context.

\footnotetext{
${ }^{71}$ Jenkins, The Next Christendom, 256.

${ }^{72}$ Escobar, "The Global Scenario,” in Taylor, Global Missiology, 35.

${ }^{73}$ D. Smith, “Contemporary Christianity in the Non-Western World.” 344.
} 
It has become evident that the new century will require a return to biblical patterns of mission. Radical shifts in culture, politics, and economics, as well as the growth of Christianity in the Southern Hemisphere, have brought new scenarios. Traditional mission models inherited from the Christendom mentality and the colonial era are now obsolete. It is time for a paradigm change that will come from a salutary return to the Word of God. ${ }^{74}$

An important question is: What should characterize Christian movements in the twenty-first centuries in response to current global contexts? One could also ask: What

\footnotetext{
${ }^{74}$ Escobar, "The Global Scenario," 43. For more on the discussion about the transmission of Faith in Christianity, see Andrew Walls, The Cross-Cultural Process in Christian History: Studies in the Transmission and Appropriation of Faith (Maryknoll, NY: Orbis, 2002).
} 
principles define the character of a Christian movement that imitates the original example? How could a Christian movement reflect the original character of Christianity in, say, Brazil? The next section of this research will seek a systematization of the elements that form the character of a true Christian movement in order to apply them to a contextual Christian expression, the Adventist movement in Brazil. 
PART II: THE ETHOS OF CHRISTIAN MOVEMENTS:

A SOCIO-RELIGIOUS SYSTEMATIZATION 


\section{CHAPTER 5}

\section{THE ETHOS OF CHRISTIAN MOVEMENTS}

The biblico-historical description in the first section highlighted the essence of Christianity and its main principles. This research design seeks to emphasize the definition of Christianity based on a biblical understanding. Social studies have developed the helpful concept of ethos to comprise, among other things, the character of movements. This part will focus on a socio-religious analysis in order to systematize the previous description and adapt a working model of the ethos of Christian movements.

This chapter will discuss the concept of ethos, including a definition, and examples. Next, an introduction of Alan Hirsch's model with a description of its parts will be offered.

\section{Culture, Worldview, and Ethos}

Paul Hiebert has been an influential voice shaping an anthropological understanding regarding culture and worldview within missiological circles in the last three decades. He argued that culture and worldview should be carefully studied for many reasons and demonstrated that mission should aim at worldview transformation. ${ }^{1}$ While

${ }^{1}$ Hiebert emphasized that it is important to study worldviews in order to understand people, especially those being served so the gospel can be effectively communicated to them; that is, in a way that implicit assumptions be judged by the gospel and worldviews transformed. Conversion often times is characterized by change in the levels closest to the surface, such as behavior and beliefs. When "the gospel is interpreted in terms of pagan worldviews, ... the result is Christo-paganism." Paul G. Hiebert, 
recognizing the considerable debate about the concept of culture, Hiebert defines it as "the more or less integrated systems of ideas, feelings, and values and their associated patterns of behavior and products shared by a group of people who organize and regulate what they think, feel, and do."2 Furthermore, he suggests that culture has several levels. Visible elements such as cultural products, patterns of behavior, and signs are found on the surface. The next level is formed by myth and rituals, followed by another level with systems of beliefs. The last level underlying those explicit structures, is formed by the implicit worldview themes. ${ }^{3}$

Worldview, the implicit level of culture, is defined by Hiebert as "the foundational cognitive, affective, and evaluative assumptions and frameworks a group of people makes about the nature of reality which they use to order their lives."4 Worldviews function as a lens, model, or map of how reality is perceived and interpreted. These assumptions are not reasoned out, just accepted. Nonetheless, worldviews are more than images of life; they are how people organize their life and experience, which is rarely questioned unless the undergirding assumptions are challenged. ${ }^{5}$ A "world view that does not actually lead a person or a people into a particular way of life is no world

Transforming Worldviews: An Anthropological Understanding of How People Change (Grand Rapids, MI: Baker Academic, 2008), 69.

${ }^{2}$ Paul G. Hiebert, Anthropological Insights for Missionaries (Grand Rapids, MI: Baker Book, 1985), 30.

${ }^{3}$ Hiebert, Transforming Worldviews, 32.

${ }^{4}$ Ibid., 25-26. 56.

${ }^{5}$ Charles H. Kraft, Anthropology for Christian Witness (Maryknoll, NY: Orbis Books, 1996), 55- 
view at all." ${ }^{6}$ Worldviews are "inhabited worlds," "sacred canopies,"8 "models for action," and "mental blueprints"9 that encompass, shape, and sustain life.

Both cultures and worldviews have three interacting dimensions: cognitive (truth), affective (aesthetics), and evaluative or normative (morality) dimensions. ${ }^{10}$ The cognitive dimension of worldview includes deep assumptions about reality. The affective dimension, also part of worldview, is formed by assumptions related to deep feelings, emotional responses, aesthetics tastes, and feelings toward other people. "Powerful, pervasive, and long-lasting affective themes," points out Hiebert, “act as a wall, protecting beliefs from attacks from within and without by providing emotional support to their truthfulness." 11 The third dimension, evaluative or normative, is made up of assumptions that "give rise to the social and moral order in a culture. They include such notions as virtues, standards, morals, and manners." 12 Since there is no definite set of assumptions for each dimension, which also varies according to culture, Hiebert

\footnotetext{
${ }^{6}$ Brian J. Walsh and J. Richard Middleton, The Transforming Vision: Shaping a Christian World View (Downers Grove, IL: InterVarsity Press, 1984), 54.

${ }^{7}$ Hiebert, Transforming Worldviews, 28.

${ }^{8}$ Peter L. Berger, The Sacred Canopy: Elements of a Sociological Theory of Religion, 1 st ed. (Garden City, NY: Doubleday, 1967).

${ }^{9}$ Geertz, The Interpretation of Cultures, 169.

${ }^{10}$ Paul G. Hiebert, The Gospel in Human Contexts: Anthropological Explorations for Contemporary Missions (Grand Rapids, MI: Baker Academic, 2009), 152.

${ }^{11}$ Hiebert, Transforming Worldviews, 59.

${ }^{12}$ Ibid., 60.
} 
discusses assumptions of each of those dimensions by looking at themes and counterthemes. $^{13}$

Assumptions found in the three dimensions are connected to unifying paradigmatic stories or myths. These master narratives bring unity, order, and coherence to ideas, emotions, experiences, and judgments. Thus, myths have two major functions: to make sense of reality and guide people's way of living. As Hiebert points out, on the one hand, "a myth is the overarching story, bigger than history and believed to be true, that serves as a paradigm for people to understand the larger stories in which ordinary lives are embedded." On the other hand, "myths codify and communicate beliefs, express the deepest feelings, and define and enforce morality. ... Myths give meaning. ... Myths are also moral charters. . . Myths tell people about the community to which they belong, their place in it, and the moral order of society."14

A third concept connected to the study of cultures and worldviews is ethos. The origin of "ethos" is found in Greek philosophy. In Gorgias, one of Plato's dialogues, a story develops between Socrates, who loves sophia ("wisdom," "truth") and Callicles, who loves the demos ("people"). In their efforts to please Athens, the demagogue uses a speech that matches the expectation in order to be accepted, even if it does not have true

\footnotetext{
${ }^{13}$ Examples of cognitive themes/counterthemes include time, space, organic/mechanistic, individual/group, group/others, this world/other worlds, naturalism/supernaturalism, human centered/god centered, science/religion, materialistic secularism/heavenly spiritualism, public sphere/private sphere, small bounded community/state, oral/literate, pluralism, patron-client/market economy, accumulation of wealth, formal/folk culture, and organic and holistic. Affective themes/counterthemes could include emotional control/emotional expression, rational discourse/amusement, yearning for home, and hybrid entertainment. And possible evaluative/normative themes/counterthemes include hierarchy, limited good, law/relationships, values/morals, freedom ad rights/responsibilities and restraints, equality/hierarchy, work/leisure, unlimited good/limited good, therapy/salvation, spiritualism/materialism, and development.

${ }^{14}$ Hiebert, Transforming Worldviews, 66, 67.
} 
virtue. The sophist will submit unalterable truth in word and deeds, even at the cost of being more unpopular. ${ }^{15}$ In his philosophy, however, Socrates develops his arguments on persuasion differently from his master. The three qualities of his system, in the context of rhetoric, are ethos, logos, and pathos.

Dictionaries define ethos as the distinguishing character, sentiment, or fundamental values of a person, group, culture or movement. ${ }^{16}$ Andrew Williams uses the term "ethical genius" to encompass the Greek ideas of èthos (character) and ethos (custom). ${ }^{17}$ Stephen K. White uses the term "distinctive spirit" as a descriptive of ethos. ${ }^{18}$ Therefore, it has been applied to a number of contexts. ${ }^{19}$ The term ethos has been defined in a number of ways and has been applied without any attempt to assert its meaning. ${ }^{20}$ Perhaps because of the broadness and somewhat fuzziness of the concept of ethos, in many literary works, it is not defined. An example is Birger Gerhardsson's The

\footnotetext{
${ }^{15}$ Terry Baxter, Frederick Douglass's Curious Audiences: Ethos in the Age of the Consumable Subject, Studies in Major Literary Authors (New York: Routledge, 2004), 3.

${ }^{16}$ Based on the definitions found in Merriam Webster, "ethos," http://www.merriam-webster .com/dictionary/ethos and American Heritage Dictionary, "ethos," http://www.ahdictionary.com/ word/search.html?q=ethos

${ }^{17}$ Andrew J. Williams, The Ethos of Europe: Values, Law and Justice in the Eu, Cambridge Studies in European Law and Policy (New York: Cambridge University Press, 2010), 10.

${ }^{18}$ Stephen K. White, The Ethos of a Late-Modern Citizen (Cambridge, MA: Harvard University Press, 2009), 1.
}

\footnotetext{
${ }^{19}$ Examples of recent uses include: the ethos of women physicians (Carolyn Skinner, Women Physicians and Professional Ethos in Nineteenth-Century America, Studies in Rhetorics and Feminisms.), of literary works (Textual Ethos Studies), of police investigations (W. Jerry Chisum and Brent E. Turvey, Crime Reconstruction, 2nd ed. (Burlington, MA: Academic Press, 2011), of photography (Esther Gabara, Errant Modernism: The Ethos of Photography in Mexico and Brazil (Durham, NC: Duke University Press, 2008).

${ }^{20} \mathrm{G}$. A. Cohen, for example, defines it as "the set of sentiments and attitudes in virtue of which its normal practices, and informal pressures, are what they are." G. A. Cohen, "Where the Action Is: On the Site of Distributive Justice," Philosophy and Public Affairs 26 (1997): 28.
} 
Ethos of the Bible, which does not present a definition of the main subject of the book. The author is satisfied with an observation in the second paragraph of the introduction, while making a case for the study of biblical ethics that relates the term to "attitudes and behavior which conform to norms." ${ }^{21}$ Part of the complication is that categorizing behavior is often difficult and categories are not always "watertight," as Jan van der Watt suggests. In the preface of the important work that he edited, van der Watt describes ethos in relation to identity and ethics. Identity would be defined by the answer to the question: "Who are you?" Ethics would be related to the question: "According to which rules are you and your groups acting and why?" Ethos would be connected to the answer to the question: "How do you behave or what do you do?"22

Although used more often today, the somewhat unfamiliar term ethos is especially relevant to emphasize the character of a movement. Ethos is a pivotal concept for sociology of religion and of social identity and is a way to understand the dynamic underlying collective values of a religious group through an analysis of attitudinal factors - the interaction between the cognitive and conative moments.

Ethos is often connected with and defined in relation to the concept of worldview. Majken Schultz's description of the relation between worldview and ethos is helpful in defining these concepts. One should "distinguish between the cognitive world view that contains the ... mental image of reality, and the ethos, which comprises the ... aesthetic

\footnotetext{
${ }^{21}$ Birger Gerhardsson, The Ethos of the Bible (Philadelphia, PA: Fortress Press, 1981), 1.

${ }^{22}$ J. G. Van der Watt, Identity, Ethics, and Ethos in the New Testament (Beihefte Zur Zeitschrift FüR Die Neutestamentliche Wissenschaft Und Die Kunde Der äLteren Kirche) (New York: Walter de Gruyter, 2006), vi-vii.
} 
and moral view of . . life in general." ${ }^{23}$ Religion, in that case, provides the specific content of that reality, "with the things in the people's model of the universe and with relationships between these things." 24

This is the same path taken by Clifford Geertz in developing a connection between anthropology and theology in the twentieth century and one of the influences in Hiebert studies. ${ }^{25}$ He identifies ethos with the moral (and aesthetic) aspects and the evaluative elements of a culture, and worldview with the cognitive and existential ones. His formal definition of ethos is "the tone, character, and quality of their life, its moral and aesthetic style and mood; it is the underlying attitude toward themselves and their world that life reflects." Worldview is defined by Geertz as a "picture of the way things in sheer actuality are, their concept of nature, of self, of society. It contains their most comprehensive ideas of order."26

Furthermore, Geertz describes the interaction between, what he calls, worldview and ethos to be a meaningful interaction between a people's values and the general order of existence-something found in all religions.

Religious belief and ritual confront and mutually confirm one another; the ethos is made intellectually reasonable by being shown to represent a way of life implied by the actual state of affairs which the world view describes, and the world view is made

\footnotetext{
${ }^{23}$ Schultz, On Studying Organizational Cultures, 89. On college campuses, for example, ethos develops symbolism and purpose in the lives of the students, creates coherence between the individual and the character of the institution, and leads to a relationship of commitment. George D. Kuh, "Ethos: Its Influence on Student Learning," Liberal Education 79, no. 4 (1993).

${ }^{24}$ Paul G. Hiebert, Cultural Anthropology (Philadelphia, PA: Lippincott, 1976), 371.

${ }^{25}$ Hiebert, Transforming Worldviews, 25.

${ }^{26}$ Geertz, The Interpretation of Cultures, 127.
} 
emotionally acceptable by being presented as an image of actual state of affairs of which such a way of life is an authentic expression. ${ }^{27}$

Thus, while Hiebert defines worldview as encompassing all three dimensions (cognitive, affective, evaluative), Geertz calls the first one, worldview, and the other two, ethos (see figure 2). Although Hiebert seems accurate in conceptualizing worldview as including all three dimensions, it seems helpful, without subscribing to Geertz's humanist tendencies, to consider his emphasis on a special dynamic between the cognitive dimension and the other two, the ethos. A people's ethos, as Geertz points out, is part of their underlying assumptions. It is a moral and aesthetic style and mood, the tone, character, and quality of their life. And it is those assumptions that will be reflected in the outer explicit layers of a culture such as symbols and patterned behaviors. Geertz explains that symbols (dramatized in rituals or related in myths) "store" meaning and "synthesize" a people's ethos and worldview. Those symbols "formulate a basic congruence between a particular style of life and a specific (if, most often, implicit) metaphysic" 28 and embed "what is known about the way the world is, the quality of the emotional life it supports, and the way one ought to behave while in it." 29

\footnotetext{
${ }^{27}$ Geertz, The Interpretation of Cultures, 127. Lester R. Kurts mentions three social functions of a people's ethos: (1) to facilitate the process of identity construction, (2) to shape and legitimate or challenge the stratification system of the social order, and (3) to identify taboo lines and to lay out the ethical guidelines in a given worldview. Lester R. Kurts, Gods in the Global Village: The World's Religions in Sociological Perspective (Los Angeles: SAGE, 2012), 145.

${ }^{28} \mathrm{Geertz}$, The Interpretation of Cultures, 90.

${ }^{29}$ Ibid., 127. Geertz emphasizes that religion is not only a model of reality but also a model for reality. He holds that "religions encourage certain feelings, attitudes, and experiences and seek to inculcate certain ritual, aesthetic, and ethical behavior. Religions consist in part of an ethos, therefore, in that they intend to mobilize people and to orient their lives." Kevin Schilbrack, "Religion, Models of, and Reality: Are We Through with Geertz?” Journal of the American Academy of Religion 73, no. 2 (2005): 431.
} 


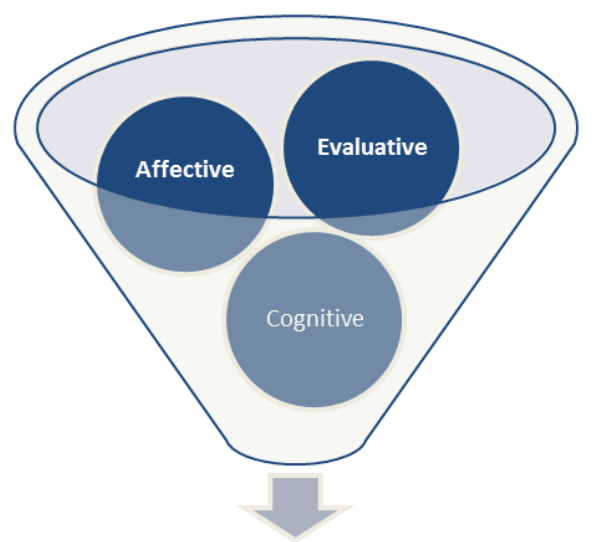

Worldview

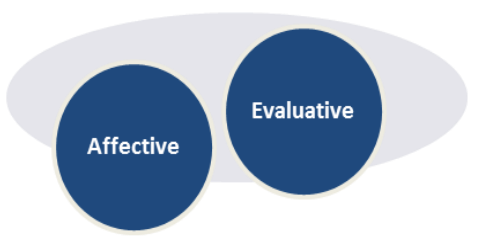

Ethos

Figure 2. Dimensions of worldview and ethos. Based on Heibert and Geertz.

Besides being a matter of conceptualization, the concept of ethos may prove to be helpful as a tool in the study of cultures, and more precisely the connection between peoples' values and behaviors, which was Geertz's original intent when he proposed his model in his seminal work, The Interpretation of Cultures.

The concepts used here, ethos and world view, are vague and imprecise; they are a kind of prototheory, forerunners, it is to be hoped, of a more adequate analytical framework. But even with them, anthropologists are beginning to develop an approach to the study of values which can clarify rather than obscure the essential processes involved in the normative regulation of behavior.... The process is not that of replacing moral philosophy by descriptive ethics, but of providing moral philosophy with an empirical base and a conceptual framework.... The role of such a special science as anthropology in the analysis of values is not to replace philosophical investigation, but to make it relevant. ${ }^{30}$

Hiebert seems to echo that view in his work more than three decades later. $\mathrm{He}$ believes that it is relevant to recover a research focus on the affective and evaluative

\footnotetext{
${ }^{30} \mathrm{Geertz}$, The Interpretation of Cultures, 141.
} 
dimensions (ethos) since "most research to date has focused on the cognitive dimension of cultures and worldviews." He further points out that "the affective dimensions are equally important in shaping the way people live their lives," and that judgments (pertaining to the evaluative dimension) "are manifest at all levels of culture, from cultural products and behavior patterns to signs, rituals, and belief systems. ${ }^{31}$ Hiebert is not suggesting to overlook or undermine the cognitive dimension, but to focus on the other two as well. A researcher should always keep in mind the interdependence between all three dimensions.

In applying the concept of worldview and ethos to the study of cultures, it should be pointed out that both are linked to social systems. In spite of the fact that people from different contexts often have very different worldviews, Hiebert balances that out by reminding us that people in a society share many aspects in their worldviews. A proof of that is the fact that they can communicate and work together. ${ }^{32}$

Developing that idea even further, Hiebert has proposed the existence of a biblically-shaped worldview with "an underlying unity to the biblical story," based on a "single story running from creation to Christ's return," including an "underlying unity and dignity of humanity," and "universal morals." This would not equate to "conscious theological formulations" but implicit categories, logic, and assumptions people develop. ${ }^{33}$ Therefore, a biblically-shaped worldview would logically suppose a biblical

\footnotetext{
${ }^{31}$ Hiebert, Transforming Worldviews, 85.

${ }^{32}$ Ibid., 86.

${ }^{33}$ Ibid., 265-266. Hiebert suggests that "to understand Scripture, we must seek to understand the worldview themes that underlie the whole. True unity of Scripture lies first in its insistence that all the biblical events are part of one great story - in other words, a central diachronic world view theme. On a
} 
ethos, in which case one could point out themes/counterthemes belonging to that reality. ${ }^{34}$

The evaluative/normative dimension, which is part of the ethos, is especially related to biblical moral themes that derive from the character of God including His holiness, righteousness, purity, and justice. ${ }^{35}$ In the context of an imperfect world marred by $\sin$, God has revealed Himself in a profound and essential way to human beings as a missionary God. His interest and intervention for the sake of human beings' salvation, allegiance to Christ, and growth in His image, are the very foundation of His plan to invite His children to engage in His mission as an essential aspect of their way of living. Therefore, the ethos would also comprise underlying assumptions about a missionary way of living. Those would generate corresponding patterned behaviors in the explicit layers of a culture.

The cultural values that are part of the evaluative dimension are also used to judge other cultures, often incurring premature judgments based on misunderstandings and ethnocentrism if one's own moral standards are not based on biblical foundations. This is especially relevant to what Hiebert calls, "transcultural persons," including missionaries who "must belong to two or more worlds, not only in terms of lifestyle and beliefs, but at

synchronic level, it affirms that the God who spoke to Abraham and David is the same God who revealed himself in the person of Jesus, that all have sinned and come short of the glory of God, and that there is no salvation apart from God's divine plan.” Hiebert, 266.

${ }^{34}$ Hiebert discusses biblical worldview themes/counterthemes such as a creator/creation, revelation/human knowledge, kingdom of god/kingdoms of this world, organic/mechanistic, group/individual (cognitive dimension); mysterium tremendum and fruits of the Spirit (affective dimension); and good/evil and justification/restoration (evaluative/normative dimension).

${ }^{35}$ Hiebert, Transforming Worldviews, 295. 
the deepest level of worldviews." 36 That dynamic is at the core of the missionary

endeavor that involves crossing cultural boundaries to love other people by being other-

centered and loving those being served.

To love is to focus attention on the persons around us. It is to ask them questions about themselves in order to truly learn to know them. It is to affirm their personhood and the gifts God has given them. And it is to invite them to come to know Jesus Christ, too, within their cultural contexts, just as we ourselves, by God's grace, have done. Such Christian love is the central element in the work of missions. ${ }^{37}$

One of the implications of rejecting the idea of a biblically-shaped worldview would be equating conversion to a change only in the other layers of culture such as beliefs and rituals. What missiologists have often pointed out is that if the implicit worldview is not also transformed, the behavior and beliefs may appear Christian, but "the underlying assumptions, categories, and logic are pagan." 38 Going back full circle, it is clear how important worldview transformation, and it could be emphasized as well, ethos transformation is. Hiebert makes reference to this as he recognizes that "although transformation may begin with cognitive and affective conversions, it must also include the moral dimension of cultures and their worldviews." 39

Transformation of a worldview is also expected to imply changes in the other levels of a culture. That should be the first step toward the development of a biblical way of living of an individual or a group. The assumption that transforming one of the extremes will automatically yield coherent related results on the other end is false. Part of

${ }^{36}$ Hiebert, The Gospel in Human Contexts, 198.

${ }^{37}$ Hiebert, The Gospel in Human Contexts, 199.

${ }^{38}$ Hiebert, Transforming Worldviews, 267. One should not see worldviews as "static forms, rather than as dynamic growing entities that are more akin to living systems than mechanical ones." Ibid., 266.

${ }^{39}$ Ibid., 313. 
the process of communicating the gospel is transforming implicit assumptions as well as explicit behavior, especially in a way that they are directly connected. The ethos should become explicit and sensorial in the practices and patterns of behavior of a group in connection with cultural signs, rituals, myths, and belief systems.

\section{Socio-Religious Movements}

Ethos, according to the definitions already presented, may be applied to a person, group, culture, or movement. This research is especially interested in that last configuration. After considering the concept of ethos previously, this section seeks to present an overview of this influential characteristic of society-social movements - in order to develop a socio-religious systematization of the ethos of Christian movements. It has been argued that an important element of understanding many of "the most significant developments and changes throughout history — such as the ascendance of Christianity, the Reformation, and the French, American, and Russian revolutions - are partly contingent on an understanding of the workings and influence of social

movements." 40 In fact, it has been suggested that we live in a "movement society."

\section{Conceptualization}

The sociological understanding about social movements has progressed with the historical development of movements themselves. Because movements, and their study, are influenced by context, sociology has had different foci throughout the last decades,

\footnotetext{
${ }^{40}$ David A. Snow, Sarah A. Soule, and Hanspeter Kriesi, eds.,"Mapping the Terrain," in The Blackwell Companion to Social Movements (Wiley-Blackwell, 2004), 3.

${ }^{41}$ David S. Meyer and Sidney G. Tarrow, The Social Movement Society: Contentious Politics for a New Century, People, Passions, and Power (Lanham, MD: Rowman \& Littlefield Publishers, 1998).
} 
such as nature of the crowds, mass society, dimensions of protest, life style, cultural meanings, and global reach. Some of the most important inquiries in this study are: When and why do social movements occur? Who joins or supports movements? Who remains in movements, and who drops out? What and how do movement participants think and feel? How are movements organized? What do movements do? How do institutions influence movements? Why do movements decline? What changes do movements bring about? ${ }^{42}$ After analyzing the abundant definitions of social movements, David Snow, Sarah Soule, and Hanspeter Kriesi concluded that most of these concepts are based on three or more of the following "conceptual axes:" (1) a form of collective action outside of institutional channels, (2) as challengers to or defenders of existing authority, (3) as organized activity, (4) as existing with some temporal continuity. ${ }^{43}$

Specific definitions differ in terms of emphasis and accents. Alfred McClung Lee, noted sociologist, pointed out in 1953 the presence of literature in social movements, that express their protest and outline their new values. ${ }^{44}$ William Kornhauser, an influential sociologist connected with the social movement theory, in 1959 emphasized that social movements are organizations to mediate between government and individuals, "a function of discontent in a society." 45 In 1970, sociologists Luther P. Gerlach and

\footnotetext{
${ }^{42}$ Jeff Goodwin and James M. Jasper, The Social Movements Reader: Cases and Concepts, 2nd ed., Blackwell Readers in Sociology (Malden, MA: Wiley-Blackwell, 2009), 7.

${ }^{43}$ Snow, Soule, and Kriesi, "Mapping the Terrain," 6-11.

${ }^{44}$ Alfred McClung Lee, Principles of Sociology, College Outline Series (New York: Barnes \& Noble, 1953), 201-202.

${ }^{45}$ Goodwin and Jasper, 11. One of the unique aspects of movements is their definition based not on membership, but on commitment, mobilization. "The movement gets its form by its form of mobilization," including central themes, ways of communicating, and shapes of organization, which are essential for its interaction with other systems of society. Moritz Klenk, "New Religious Movements in Global Perspecticv: A Systems Theoretical Approach," Zeitschrift für junge Religionswissenschaft 7 (2012): 46.
} 
Virginia H. Hine added that besides having a segmented, cellular organization, an ideology of articulated values and goals, and real or perceived opposition, social movements are characterized by face-to-face recruitment by committed individuals using their own preexisting, significant social relationships and personal commitment generated by an act or experience that separates a convert in some way from the established order, identifies him or her with a new set of values, and commits him or her to changed patterns of behavior. ${ }^{46}$

In the late 1980s, one dimension particularly significant to this research, the cultural side of social movements, aroused the interest of scholars. ${ }^{47}$ Different from the economic and political emphases, in the cultural approach social movements are related for example, to efforts to change society, more specifically “by controlling a society's symbols and self-understandings." ${ }^{48}$ Discontent associated with a different way of seeing the world has given a moral dimension to many movements. They are both cause and effect of social change. "They embody the emergence of a new ethos, . . . a new ethical orientation towards ... the living of everyday life, a new conception of what 'the good life' would be."49

\footnotetext{
${ }^{46}$ Luther P. Gerlach and Virginia H. Hine, People, Power, Change: Movements of Social Transformation (Indianapolis, IN: Bobbs-Merrill, 1970).

${ }^{47}$ Goodwin and Jasper, The Social Movements Reader, 6.

${ }^{48}$ Ibid., 13. "Culturalists have reasserted the importance of perceptions, ideas, emotions, and grievances, all of which mobilization and process theorists once thought did not matter or could be taken for granted. But these are examined today in the context of broader social and political changes, not in isolation from them." Ibid., 14. 2002), 68 .

${ }^{49}$ Nick Crossley, Making Sense of Social Movements (Philadelphia, PA: Open University Press,
} 
Social movements can be viewed as collective enterprises seeking to establish a new order of life. They have their inception in a condition of unrest, and derive their motive power on one hand from dissatisfaction with the current form of life, and on the other hand, from wishes and hopes for a new system of living. The career of a social movement depicts the emergence of a new order of life. ${ }^{50}$

Thus, as Steve Addison summarizes it, "movements are characterized by discontent, vision, and action." 51

Social movements may differ according to their character. Classical examples include the environmental movement, the civil rights movement, feminism, gay rights, and communism. This research is particularly interested in religious movements, which, in spite of their similarities to other social movements, are unique because of their religious character. William Sims Bainbridge defines a religious movement as "a relatively organized attempt by a number of people to cause or prevent change in a religious organization ${ }^{52}$ or in religious aspects of life. ${ }^{, 53}$ Lee expands that definition by

\footnotetext{
${ }^{50}$ Herbert Blumer, Symbolic Interactionism: Perspective and Method (Englewood Cliffs, NJ: Prentice-Hall, 1969), 99, cited in Crossley, Making Sense of Social Movements, 3.

${ }^{51}$ Addison, Movements That Change the World, 28. In that respect, Addison also points out that "so much of history is the result of the clash of movements vying over their conflicting visions of how the world should be." Ibid., 27.

52،It should be apparent that this same range of social movement activity in the larger society may also be found within organizations. Some conflicts in organizations consist of small-scale insurrections, as when a small number of members of a denomination insist upon using altered ritual formats; others lead to heresy trials; still others may lead to a coup d'état as very few result in mass movements such as the Charismatic movement in the American Catholic Church or the Liberation Theology movement within the Latin American Catholic Church." Mayer N. Zald and John D. McCarthy, Social Movements in an Organizational Society: Collected Essays (New Brunswick, NJ: Transaction Books, 1987), 85.

${ }^{53}$ William Sims Bainbridge, The Sociology of Religious Movements (New York: Routledge, 1997), 3. Related categories have been suggested, such as religiously-based social movements, including Social Gospel Movement, the Civil Rights Movement, the New Christian Right, in which religion is the source of ideas, people, and organization for mobilizations for social change. Rhys H. Williams, "Religious Social Movements in the Public Square," in A Handbook of the Sociology of Religion, ed. Michele Dillon (New York: Cambridge University Press, 2003), 315. Another category is the religiously-based political movements such as Liberation Theology, Rastafari, Islamist Movements (The Iranian Revolution,
} 
stating that religious movements develop an expressive behavior based on their original unrest that becomes evident in the personalities of individuals and the character of the social order. Major characteristics of these movements follow the general outline of social movements. ${ }^{54}$ Most importantly, the program of a religious movement "represents a new way of living and it aims at a moral regeneration of the world." 55

Religious movements, in this sense, are related to the sociological continuum between sects, denominations, and churches. While this could apply to expressions of virtually any world religion, the focus of this research is on Christian movements. As demonstrated in the first chapter, Jesus founded a missionary movement, or as Steve Addison points out, "a movement of movements."56

\section{Life Cycle of Movements}

A crucial understanding about social movements is their developments over time- the life cycle of movements. According to this sociological concept, over time social movements may transition into a social institution. While in the beginning a social movement is amorphous, poorly organized, and with elementary mechanisms of interaction, as it develops, organization, form, a body of customs and traditions, established leadership, division of tasks, social rules, and social values arise. This life

Hezbollah, Al-Qaeda, Taliban), Sikh Political Activism, Hindu Political Activism. Britannica Guide to Political and Social Movements by Heather Campbell.

${ }^{54}$ Lee underlines some of those aspects: intense intimacy and esprit de corps, heightened feeling of exaltation, projection of the collective feelings on outside objects. Lee, Principles of Sociology, 214-215.

${ }^{55}$ Ibid., 216.

${ }^{56}$ Addison, Movements That Change the World, 32. 
cycle gives birth to a new culture, a new social organization, a new scheme of life. ${ }^{57}$ The observation is that what starts as a movement gradually loses its initial type of ethos. ${ }^{58}$ The goal of this section is not to discuss the details of what happens at each stage, but to introduce this classic theory that is part of the fabric of a sociology of religion.

Already in 1935 Carl A. Dawson and Warner Gettys suggested four stages of movement development: social unrest, popular excitement, formalization, and institutionalization. During the first phase, there is no organization or discipline but an agitator-type of a leader and a loose association of people whose action is determined by their interaction. During the popular stage, the movement becomes fairly coordinated, develops a common goal and universal appeal; myths and doctrines appear under the leadership of a prophet and/or reformer-type. Next, there is the formal organization structured around its statesman-type leaders, their programs, and established aims; literature is developed, including hymns. The institutional stage, the last one, is the culmination of a "successful" social movement. The leader becomes an administrator and none of the other types have a place in this arrangement where laws, disciplines, dogmas, and ideals are more important than the people. Several replacements take place during that process: lay leadership by official clergy; doctrines by creeds; protest by formalism. ${ }^{59}$ This is the end of the cycle, since change has been achieved. Although

${ }^{57}$ Lee, Principles of Sociology, 216.

${ }^{58}$ Hirsch, The Forgotten Ways, 116.

${ }^{59} \mathrm{H}$. Richard Niebuhr, The Social Sources of Denominationalism (New York: Meridian Books, 1957), 19-21. 
passing over into the next stage is done almost imperceptibly, not all movements go through this sequence, since some die out in the early stages. ${ }^{60}$

Religious movements seem to develop in similar patterns of development. Ernst Troeltsch, influenced by Max Weber, introduced the church-sect typology, which defines the differentiation between sect and church categories of religious organization. $\mathrm{H}$. Richard Niebuhr, using such categories, described the life cycle of religious bodies as a process in which, over time, cults become sects that, in turn, become denominations. ${ }^{61}$ David O. Moberg describes that process in five stages: incipient organization, formal organization, maximum efficiency, institutional, and disintegration. After the last stage, there is usually a reorganization or a reenacting of the same cycle within the same church or as a new initiative. In reality, as Moberg points out, there is some overlapping between the phases. Also, not all movements go through all five stages since some become stagnant at a certain point and others skip a stage by rapidly moving ahead. The entire cycle can last from a generation to over a hundred years. Finally, the process may be reversed; it is not inevitable. ${ }^{62}$

Several dynamics are observed in connection with the development of religious bodies. For Niebuhr, the life cycle of religious movements is related to the passing of

${ }^{60}$ C. A. Dawson and Warner E. Gettys, An Introduction to Sociology, rev. ed. (New York: Ronald Press, 1935), 709-725.

${ }^{61}$ Ruth B. Bordin, "The Sect to Denomination Process in America: The Freewill Baptist Experience," Church History 34, no. 1 (1965): 77. William H. Swatos and Peter Kivisto, Encyclopedia of Religion and Society (Walnut Creek, CA: AltaMira Press, 1998). Church-sect Theory. Lee equals religious movements to sects (p. 116).

${ }^{62}$ David O. Moberg, The Church as a Social Institution: The Sociology of American Religion, 2nd ed. (Grand Rapids, MI: Baker Book House, 1984), 119-124. 
generations. When the children of adherents are born, the sect takes on aspects of an educational and disciplinary institution. Somewhat related to that is the fact that, convictions of successive generations are less fervent than that of the pioneers and compromise is inevitable. ${ }^{63}$ Thus, sects tend to originate with an anti-ritualistic attitude but adherents soon realize the importance of rituals in order to simplify social interaction, reinforce beliefs, and integration. "As ritualism formalizes expressions of faith by believers, it also contributes to mobility of the religious body from sect toward church." 64 Finally, it has been observed that the vitality of religious movements is related to interaction with their context. "New religious movements fail when they become closed or semi-closed networks. For continued exponential growth, a movement must maintain open relationships with outsiders. They must reach out into new, adjacent social networks. ${ }^{965}$

Some have also identified the dynamics of socio-religious movements in Christianity, which began as a rejected Jewish cult, became a persecuted sect, and became a religious system or a denomination. ${ }^{66}$ Furthermore, within it, as within many religious movements, there were numerous sectarian movements. ${ }^{67}$ Those dynamics have

\footnotetext{
${ }^{63}$ Niebuhr, The Social Sources of Denominationalism, 19-21.

${ }^{64}$ Moberg, The Church as a Social Institution, 101.

${ }^{65}$ Addison, Movements That Change the World, 52.

${ }^{66}$ Dawson and Gettys, An Introduction to Sociology, 710.

${ }^{67}$ Ibid.
} 
been studied by Moberg as for example in the history of Wesleyan Methodism, the Church of the Nazarene, Christian Science, the Salvation Army, and Mormonism. ${ }^{68}$

The vitality of Christian movements, especially in connection with their missionary thrust, has been identified with their first stage. Dawson and Gettys, who also have researched the Methodist movement, made that remarkable observation. Talking about the early stage of the Methodist movement, they comment that "from this time the leaders of the movement became the most active of missionaries. Without any fixed parishes they wandered from place to place, proclaiming their new doctrine in every pulpit to which they were admitted, and they speedily awoke a passionate enthusiasm and a bitter hostility in the church." "99 "Perhaps each major Christian body is destined to follow a similar sequence of development with repeated splintering of smaller sects aimed at reform." $" 70$

Addison has suggested that movements are "one of the key means by which God brings renewal and expansion to the church in its mission."71 The opposite observation seems to correspond to reality as well. "The larger the church grows in terms of membership, the more machinelike and inorganic its systems, structures, and social patterns will tend to become." 72 Consequently that is part of the nature of most

${ }^{68}$ Moberg, The Church as a Social Institution, 101-105.

${ }^{69}$ Dawson and Gettys, An Introduction to Sociology, 714.

${ }^{70}$ Moberg, The Church as a Social Institution, 101.

${ }^{71}$ Addison, Movements That Change the World, 32.

${ }^{72}$ Michael Frost and Alan Hirsch, The Shaping of Things to Come: Innovation and Mission for the 21st-Century Church (Peabody, MA: Hendrickson Publishers, 2003), 212. 
denominations since they find themselves on the down side of the life cycle. It is expected that "most established institutions will resist the movement ethos." "73 As Bosch points out, in those cases, the issue is not the institutionalization per se but the loss of its movement verve.

Its white-hot convictions, poured into the hearts of the first adherents, cooled down and became crystalized codes, solidified institutions, and petrified dogmas. The prophet became a priest of the establishment, charisma became office, and love became routine. The horizon was no longer the world but the boundaries of the local parish. The impetuous missionary torrent of earlier years was tamed into a stillflowing rivulet and eventually into a stationary pond. ${ }^{74}$

Since the life cycle of religious bodies with its stages seems to be inevitable, and since there is a desire to keep the vitality of the movement phase, especially in terms of the mission impulse, what is the solution? "The goal of churches should be to achieve what strategists call 'sigmoid growth,' which is the capacity to constantly remain in a state of movement-like growth."75 The goal is to maintain or to reawaken, depending on the case, a movement ethos.

\section{Ethos of Christian Movements}

Even a cursory search of the combination of words "social movement ethos" on Google books will yield results that relate the concept in terms of sports and social movements, social movements and activism in the USA, the Nicaraguan Women's

\footnotetext{
${ }^{73}$ Ibid., 206. "History is absolutely clear about this: most established institutions will resist a movement ethos. It's just too chaotic and uncontrollable for institutions to handle. That is why most movements are ejected from the host organization. This needn't be the case, but it does require a significant permission-giving at high levels of denominational or established organization leadership to ensure that they are not." Ibid., 206.

${ }^{74}$ Bosch, Transforming Mission, 53.

${ }^{75}$ Frost and Hirsch, The Shaping of Things to Come, 203.
} 
movement, social movements in India, music and social movements. Ethos is also part of the language about Christianity. Although, currently the most common use may be the development of ethos statements for schools ${ }^{76}$ as part of the current critique of Christianity, and of Adventism, ${ }^{77}$ Christian scholars also have turned their attention to the study of the nature of movements and their ethos in search for the core where "latent missional potencies" $" 78$ or the "life force and guiding mechanism of God's people" are built in and can be unleashed in contextualized strategies of evangelization.

The goal of this approach to the Bible and history is to identify ideals, principles, and dimensions that can bridge the gap between those contexts and today's. Those elements should not be disconnected from specific cultural expressions that transformed them into actions, habits, and customs, but should be seen in conjunction with careful exegesis and a study of the biblical material. The objective is not to form an independent construct disconnected from Bible narratives but a model that continues to derive, systematize, and transport the essential character of Christianity across contexts. ${ }^{80}$ "In

\footnotetext{
${ }^{76}$ A Google search for the term "Christian ethos" results in about 179,000 links.

${ }^{77}$ For example, George R. Knight, The Fat Lady and the Kingdom: Adventist Mission Confronts the Challenges of Institutionalism and Secularization (Boise, ID: Pacific Press Pub. Association, 1995); Idem., The Apocalyptic Vision and the Neutering of Adventism; Malcolm Bull and Keith Lockhart, Seeking a Sanctuary: Seventh-day Adventism and the American Dream, 2nd ed. (Bloomington, IN: Indiana University Press, 2007); Eva Keller, The Road to Clarity: Seventh-day Adventism in Madagascar, Contemporary Anthropology of Religion (New York: Palgrave Macmillan, 2005).

${ }^{78}$ Hirsch, The Forgotten Ways, 15.

${ }^{79}$ Ibid., 18.

${ }^{80}$ Richard Hays discusses the method of extraction of ideals or principles. Richard B. Hays, "Mapping the Field: Approaches to New Testament Ethics," in Identity, Ethics, and Ethos in the New Testament, ed. Jan G. van der Watt (New York: Walter de Gruyter, 2006), 9.
} 
this model, the stories of the New Testament canon are privileged. We do not stand in judgment over them; rather, they confront and form and shape us." ${ }^{\prime 1}$

Thus, Hirsch points out that "in order to recover the missional vitality of the early church, we have to reawaken a virile movement ethos in so many of the organizations we inhabit. And to do that we need to . . get back to the . . way of Jesus." 82

\begin{abstract}
Alan Hirsch's Model
Among the few people who have developed a model for the ethos of Christian movements, ${ }^{83}$ Alan Hirsch has received much attention for his proposal in The Forgotten Ways where he suggests a paradigm of "absolutely irreducible components" that are interrelated and form the principles of that which he calls missional DNA, mDNA, and apostolic genius. The purpose of this section is to offer a description of the main elements of Hirsch's model followed by a presentation of major assumptions behind them.

Most expressions of Christianity today seem to struggle with a lack of vitality by its adherents and of relevance in their context. In many ways it seems like Christians are lost "in a perplexing global jungle where our well-used cultural and theological maps
\end{abstract}

\footnotetext{
${ }^{81}$ Hays develops his own model for relating Scripture and ethics and calls it "metaphorical embodiment of narrative paradigms." Ibid., 16.

${ }^{82}$ Hirsch, The Forgotten Ways, 195. "We must constantly subject our institutions to prophetic critique, because it is the prophet, in his or her simple call to faithfulness to God alone, that is most aware of the dangers of the claims that institutions make on faith." Ibid.

${ }^{83}$ Two other examples of models are the ones suggested by Addison and by Snyder. Addison identifies five characteristics of a missionary movement: white-hot faith, commitment to a cause, contagious relationships, rapid mobilization, and adaptive methods. Addison, Movements That Change the World, 22-24. Howard Snyder identifies the following eight characteristics of movements: a thirst for renewal, a new stress on the work of the Spirit, an institutional-charismatic tension, a concern for being a countercultural community, nontraditional or nonordained leadership, ministry to the poor, energy and dynamism. Howard Snyder, New Wineskins: Changing the Man-Made Structures of the Church (London: Marshall, Morgan, and Scott, 1978).
} 
don’t seem to work anymore." ${ }^{\circledR 4}$ Motivated by challenges both from within and without, Hirsch has sought to identify "latent inbuilt missional potencies" that characterize most remarkable Jesus movements ${ }^{85}$ in history. He suggests that reaching back into our past is part of the solution and that the issue is that usually "we don't go back far enough" until we reach the "very roots of what it means to be Jesus' people." 86

Hirsch has designed his model based on the DNA metaphor and the understanding that these core principles of Christian movements (1) are found in every living cell, (2) carry genetic information for the transmission of inherited traits, (3) are selfreplicating, and (4) carry vital information for healthy reproduction. To him, this is "the life force that pulsated through the New Testament church and in other expressions of apostolic Jesus movements throughout history." ${ }^{187}$

Hirsch's model can be pictured as a pentagram around a central element. These are the elements: (1) Confession that Jesus Is Lord, (2) Disciple Making, (3) MissionalIncarnational Impulse, (4) Apostolic Environment, (5) Organic Systems, and (6) Communitas, Not Community (see figure 3).

\footnotetext{
${ }^{84}$ Hirsch, The Forgotten Ways, 16.

${ }^{85} \mathrm{Hirsch}$ uses terms such as "apostolic movements," "phenomenal movements," and "Jesus movements" interchangeably. He defines movement as "a group of people organized for, ideologically motivated by, and committed to a purpose which implements some form of personal or social change; who are actively engaged in the recruitment of others; and whose influence is spreading in opposition to the established order within which it originated." Frost and Hirsch, The Shaping of Things to Come, 202.

${ }^{86}$ Hirsch, The Forgotten Ways, 17.

${ }^{87}$ Ibid., 76-77. "As DNA carries the genetic coding, and therefore the life, of a particular organism, so too mDNA codes Apostolic Genius," which is "the total phenomenon resulting from a complex of multiform and real experiences of God, types of expression, organizational structures, leadership ethos, spiritual power, mode of belief, etc." Ibid., 78.
} 
He believes this to be "a powerful paradigm grid with which we will be able to assess our current understandings and experiences of church and mission." 88 Hirsch further contends that the development of each element of his model will take a Christian movement closer to the original character of Christianity but, in order to trigger metabolic growth all six elements should be developed since they are interconnected. "A movement operating with Apostolic Genius is," he asserts, "a distinctly higher and more authentic form of ecclesia than that which might have existed before." 89

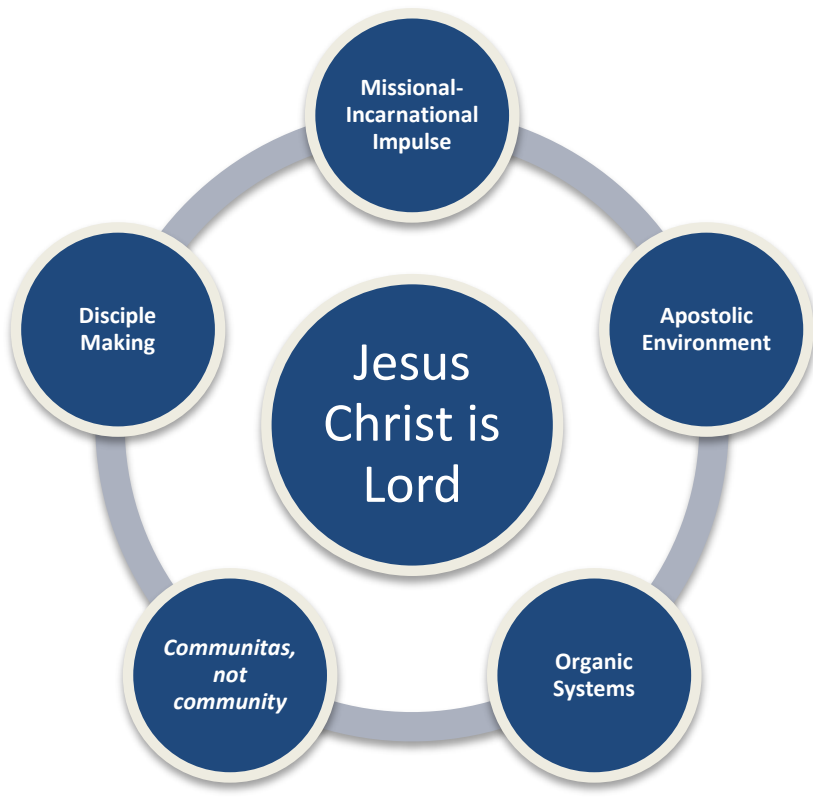

Figure 3. Hirsch's model of a Christian movement ethos. Taken from Hirsch, The Forgotten Ways, 25.

${ }^{88}$ Ibid., 24.

${ }^{89}$ Hirsch, The Forgotten Ways, 76. 


\section{Confession That Jesus Is Lord}

At the center, there is a confession about God. Hirsch realizes the simplification of this element and does not think that one should engage in theological reductionism. He acknowledges essential aspects of Christ's teachings about the kingdom of God, the doctrine of incarnation, the missio Dei (the mission of God), and others. However, the "definite central core" of remarkable Jesus movements, he identifies as being the confession that Jesus is Lord. $^{90}$

Hirsch credits this to a simple and profound comprehension about the One True God, which involves a living encounter and which can be easily grasped and passed on by anyone. This is the foundation of all genuine Christian movements. The centrality of that attitude is demonstrated by the monotheistic affirmation of the People of Israel and their relation to the fulfilled promise about the Messiah within the covenantal context. ${ }^{91}$ True Christian expressions are essentially linked to Jesus, as Mediator, as "the way" to the Father, and seek "to consistently embody the life, spirituality, and mission of its Founder."92

In the Hebraic worldview, that understanding meant more than a statement about God; it was an existential claim and a holistic surrender of every aspect of life. The Torah had a major role in teaching everyone to submit their lives to God. Jesus, as the

\footnotetext{
${ }^{90}$ Deut 6:4, 1 Cor 8:4-6, and Rom 11:33-36 are cited as key texts about "the epicenter of the biblical consciousness of God."

${ }^{91}$ Hirsch, The Forgotten Ways, 84, 87-88.

${ }^{92}$ Ibid., 94. As Hirsch points out, these were "Jesus movements." Alan Hirsch and Darryn Altclass, The Forgotten Ways Handbook: A Practical Guide for Developing Missional Churches (Grand Rapids, MI: Brazos Press, 2009), 38.
} 
incarnated God, not only demonstrates, but is that reality Himself. The call of Jesus was for His disciples to live the reality of His kingdom, especially as He sat at the right hand of God. The acknowledgment that Jesus was Lord and the exclusion of other claims to loyalty, resulted in the refusal to accept the lordship of Caesar. This undermined the Roman government and got Jesus's disciples in trouble. "They knew that this was the heart of the faith, and they could not, would not, surrender it." 93

This concrete and practical thinking shaped their worldview and their way of living while avoiding dualistic expressions of faith that led to practical polytheism. ${ }^{94}$ It also fostered the development of a tenacious faith. Hirsch highlights the role of persecution in many expressions of Christianity, especially among the early Christians, that focused their attention on the essence of the message and motivated them to be more faithful and hopeful followers of Jesus their Lord. In perilous situations, movements become more subversive, develop a more dynamic structure, and foster better relational networks. The clue to how to recover the ethos of authentic Christianity, concludes Hirsch, is found in that phenomenon of "identifying, distilling, and living (even dying) by its message." ${ }^{95}$ Thus, it is essential "to refocus our attention back to the Root of it all, to recalibrate ourselves and our organizations around the person and work of Jesus the Lord." 96

\footnotetext{
${ }^{93}$ Hirsch, The Forgotten Ways, 92.

${ }^{94}$ In terms of incarnational mission, Hirsch sees that Christocentric monotheism as a mechanism against syncretism. Negative examples that he gives include the apartheid in South Africa and the genocide in Rwanda, where the spiritual dimension was put aside in highly Christianized contexts.

${ }^{95}$ Ibid., 86.

${ }^{96}$ Ibid., 94.
} 


\section{Missional-Incarnational Impulse}

The two defining characteristics of a missional-incarnational impulse, one of the more clearly identifiable elements in Christian movements, are a dynamic outward thrust and a related deepening impulse. The first characteristic is influenced by the shift in missiology in the last forty years that has helped to refocus the mission as belonging primarily to God, who is a missionary God, and the church as the sent people. Hirsch explains that "this 'sending' is embodied and lived out in the missional impulse. This is in essence an outwardly bound movement from one community or individual to another. It is the outward thrust rooted in God's mission that compels the church to reach a lost world."97

The second characteristic is shaped by a profound understanding and the adoption of the incarnation as the model for missions, which, according to Hirsch, is characterized by presence, proximity, powerlessness, and proclamation. ${ }^{98}$ In the mysterious event of the incarnation, Christ's redemptive mission involved "profound affinity, a radical identification with all that it means to be human" and "revelation: by taking upon himself all aspects of humanity, Jesus is for us, quite literally the human Image of God."99

Hirsch concludes that mission today should follow the incarnational and revelatory aspects of God's paradigm as a pair of scissors in which the incarnational

\footnotetext{
${ }^{97}$ Hirsch, The Forgotten Ways, 129.

${ }^{98}$ In the ministry of Jesus these elements are identified by Hirsch as follows: presence, the incarnation of Jesus among humanity; proximity, Jesus' interaction with people from all levels of society; powerlessness, His model of servanthood and humility; and, proclamation, the sharing of the gospel story. Hirsch and Altclass, The Forgotten Ways Handbook, 88-89.

${ }^{99}$ Hirsch, The Forgotten Ways, 132.
} 
blade is shaped by Jesus' mission and the missional one by the mission of God. The practical implications of this element are identified by Hirsch as (1) being antidotes for colonization tendencies that alienate local Christians since they shape practices that embed and deepen the gospel in a people group in order to become God's people; (2) developing reproductive capacities by the church; and (3) making it organically embedded in the fabric of the host community. ${ }^{100}$ Finally, the suggestion is to start with Jesus and keep Him as a constant reference point for one's missiological approach. "It is Christ who determines our purpose and mission in the world, and then it is our mission that must drive our search for modes of being-in-the-world."101

\section{Apostolic Environment}

This element of Hirsch's model is a combination of apostolic influence and a fertile environment. Apostolic influence, "a powerful form of catalytic influence," is modeled after the biblical concept of apostolic leadership. Hirsch identifies three essential characteristics of apostolic ministry among the early Christians: (1) it was seen as both a gifting and a calling by God; (2) it was authenticated by a life lived consistent with the message; and (3) it was recognized by its effects on the movement and its context, especially the fulfillment of God's mission. Following that paradigm, Hirsch suggests

\footnotetext{
${ }^{100}$ Hirsch, The Forgotten Ways, 135-140. Hirsch points out that powerful movements begin "with a group of people impassioned with a cause that reproduces itself through multiplication systems. . . . Something happens when we try to control things too much that serves to lock up the power of multiplication, and the movement moves on to addition and then on to subtraction." Ibid., 139. He also talks about understanding "from the inside the issues that a people group faces what excites them, what turns them off, what God means for them, and where they seek redemption.” Ibid., 140. See map with six steps on this process in Hirsch and Altclass, The Forgotten Ways Handbook, 108.

${ }^{101}$ Hirsch, 143. This process is reflected in the title of his major book The Forgotten Ways and in Hirsch's proposal that Christology should determine missiology and that in turn should shape ecclesiology. Ibid., 142, 143.
} 
that, in practice, the apostolic ministry has three primary objectives: (1) to embed the ethos of Christianity by pioneering new missionary work for the gospel; (2) to guard the ethos of Christianity by applying and integrating mission theology; and (3) to foster the ethos of Christianity by creating an environment for other ministries to emerge. Thus, an apostolic ministry has the responsibility of a custodian of the missionary ethos of Christian movements, as well as the tasks of providing the environment and the reference point for the other ministries. ${ }^{102}$

Apostolic ministry does this by reawakening the people to the gospel and embedding it in the organizational framework in ways that are meaningful. ... Watch what the biblical apostles do; they engage in missionary work, establish new churches, and once established they move off to new frontiers. . . . Apostles are not just hot-headed entrepreneurs; they are also working theologians. . . . This impulse to ensure doctrinal integrity is therefore another key characteristic of apostolic ministry. ${ }^{103}$

Based on Eph 4:7-11, Hirsch develops a model for apostolic ministry that he calls APEPT (apostolic, prophetic, evangelistic, pastoral, and teaching/didactic). ${ }^{104}$ According to him, all five ministries are essential for vigorous, healthy, and growing movements. Their relation to each other works as a maturity mechanism as each ministry provides the

\footnotetext{
${ }^{102}$ Hirsch, The Forgotten Ways, 150-157. "In declining denominational systems, such people are commonly 'frozen out' or exiled because they disturb the equilibrium of a system in stasis. This 'loss' of the apostolic influencer accounts for one of the major reasons for mainstream denominational decline." Ibid., 152. Hirsch points out that this is what happens between Jesus and His disciples, and Paul and his team. They were able to "create environments wherein the apostolic imagination of God's people can be evoked, the spiritual gifts and ministries developed, and the love and hope inspired by the gospel be made known." Ibid., 163. See chart about the apostolic task in Hirsch and Altclass, The Forgotten Ways Handbook, 115-116.

${ }^{103}$ Hirsch, 156. Hirsch exemplifies this dynamic of apostolic ministries with names such as Patrick, John Wesley, Ignatius of Loyola, John Wimber, William Booth, William Carey, and the countless unnamed apostles of the Chinese underground church who developed a "dual element of pioneer missionary and working theologian." Ibid.

${ }^{104} \mathrm{Hirsch}$ dedicates a whole chapter for the genius of APEPT in Frost and Hirsch, The Shaping of Things to Come, 165-181.
} 
environment for the subsequent one to flourish. Apostolic ministry, Hirsch points out, is based on inspirational or moral leadership, which is authenticated by suffering and empowerment, service and calling, not by positional claims. This ministry can have its influence diminished by a dictatorial, top-down style of leadership that fosters childlike, powerless, and dependent church members. The opposite dynamic is expected in which leaders and followers are transformed by their interaction that raises their level of motivation and morality, their conduct, and ethical aspirations on the basis of shared values, calling, and identity. "In this view, followers are persuaded to take action without being threatened or offered material incentives, but rather by an appeal to their values." 105

Hirsch believes that APEPT is assigned to the entire church, not just leadership. ${ }^{106}$ Leadership would be "a calling within a calling," with the assignment to lead and influence the body of Christ, and not just ministering. He also suggests that it is rare that someone is connected with only one of the ministries found in the, definitive but not final, list of Ephesians. These ministries rely on the various spiritual gifts according to the guidance of the Holy Spirit. Finally, Hirsch points out that "at best, movements and churches without apostolic influence can only pick up aspects of [Christian ethos]; they cannot connect them in that cohesive, synergistic whole that constitutes true Apostolic Genius."

\footnotetext{
${ }^{105}$ Hirsch, The Forgotten Ways, 158-160. Hirsch views the impact of apostolic leadership as having little to do with personality, charisma, or style and more to do with working with the "dormant energy." He uses the illustration of "midwives to a new dream" or farmers to "natural rhythms of nature." Ibid., 164, 166.

${ }^{106}$ Frost and Hirsch, The Shaping of Things to Come, 171.

${ }^{107}$ Hirsch, The Forgotten Ways, 177. Hirsch understands that APEPT should operate as a system.
} See chart in Hirsch, 176. 


\section{Organic Systems}

Hirsch draws on biblical images like body, field, yeast, seeds, trees, living temples, vines, and animals, which he considers "not just verbal metaphors that help us describe the theological nature of God's people but actually go to issues of essence,"108 in

\footnotetext{
${ }^{108}$ Ibid., 180. Hirsch points out that when Jesus says "the kingdom of God is like," he is teaching about operational principles of the kingdom. Hirsch and Altclass, The Forgotten Ways Handbook, 139.
} 
order to structure the life of an organization (living systems approach). "All living systems," points out Hirsch, "require some form of structure in order to maintain and perpetuate their existence. And while it is entirely true that structure does not in itself create life (as in a machine), without it life cannot exist for very long."109

Based on that, four principles are listed: (1) all living things have innate intelligence that involves aptitude for survival, adaptation, and reproduction, (2) life is profoundly interconnected, (3) living systems respond to information, which brings change, and (4) adaptive challenges lead to emergence of new forms of organization. In reality, Hirsch points out that there is an organizational dimension to the task of leadership described in the last section. Thus, the task of leadership is related (1) to unleashing the ethos that is dormant in the system, (2) to bringing the various elements in the system into meaningful interrelationship (a "relationally networked" body of Christ), (3) to helping the system become highly responsive to its environment, and (4) to selecting the flow of information and focus the community around it. ${ }^{110}$

Referring to the life cycle of religious bodies, Hirsch identifies those aspects with the description of movements, including the early Christian movement. Issues arise when movement structures become centralized governance, when institutions take on a life of their own, and when they become obstacles to mission. In those cases, a hard-to-change culture of restraint is developed in well-meaning structures because so much power is concentrated in the religious institution. A denomination may even refer to itself as a

\footnotetext{
${ }^{109}$ Hirsch, The Forgotten Ways, 186.

${ }^{110}$ Ibid., 182-184.
} 
movement and not display movement ethos. It seems that, after getting to that point, "no historical denomination has ever been able to fully recover its earlier, more fluid and dynamic movement ethos again."111

In order to keep a movement ethos, Hirsch suggests the need of decentralizing, spreading, and multiplying. He suggests a network structure with nodes and hubs that is, over time and distance, to a large degree based on common beliefs, principles, interests, and goals. That also is an antidote to unnecessary command and control. In terms of reproducibility, which is also related to living systems, movements, and networks, the core identity passed on has to be simple, reproducible, and embedded with all that is needed for healthy expressions of Christianity. ${ }^{112}$ In summary, the feel of a movement, the structure of a network, and multiplication that spreads like a virus enables growth that is organic, spontaneous, and hyperbolic. ${ }^{113}$

\footnotetext{
${ }^{111}$ Hirsch, The Forgotten Ways, 188. Hirsch alerts us to the possibility of replacing vision and mission by programming and administration and developing a "monopolizing grip that the institutional image of the church holds over our theological imaginations, and allows us to undertake a journey of reimagining what it means to be God's people in our own day and in our own situations." Ibid., 199. Hirsch cites the hobbling of the organic Celtic mission by the centralist Roman Catholic Church in Britain. Ibid., 188.

${ }^{112}$ Ibid., 202, 207, 213. Hirsch calls reproducibility "one of the most powerful elements of organic systems." Ibid., 207. "Purpose and principle, clearly understood and articulated, and commonly shared, are the genetic code of any healthy organization. To the degree that you hold purpose and principles in common among you, you can dispense with command and control. People will know how to behave in accordance with them, and they'll do it in thousands of unimaginable, creative ways. The organization will become a vital, living set of beliefs." Dee Hock, cited in Hirsch, 202.

${ }^{113}$ Hirsch, The Forgotten Ways, 25, 180. Hirsch's contrasting description of organic missional movement and institutional religions characteristics are found in Hirsch and Altclass, The Forgotten Ways Handbook, 141.
} 


\section{Communitas, Not Community}

The concept of communitas $^{114}$ depicts the experience of people driven to each other through a common experience characterized by ordeal, humbling, transition, and marginalization. Hirsch uses this term to imply the most vigorous kinds of community, which takes many forms and describes the typical "communality" and "comradeship" of Christian movements. He believes that rather than a temporary experience, this is "the normative situation and condition of the pilgrim people of God."115

The need of a different term for community comes from the observation that in spite of their busyness, Christians rarely have a real impact in their context. Middle-class culture has become obsessive with safety and security fused with consumerism, which results in a search for comfort and convenience. Thus, Hirsch believes a paradigmatic change has happened from the missional idea of "me for the community and the community for the world" to the more consumptive "the community for me." In that context, a defining concept in Hirsch's discussion of communitas is liminality, which is "that situation where people find themselves in an in-between, marginal state in relation to the surrounding society." 116 When applied to the idea of community, liminality causes an experience of, what Hirsch calls, togetherness "that only really happens among a

\footnotetext{
${ }^{114}$ Hirsch borrows this term from Victor W. Turner, The Ritual Process: Structure and AntiStructure, Symbol, Myth, and Ritual Series (Ithaca, NY: Cornell University Press, 1977).

${ }^{115}$ Hirsch, The Forgotten Ways, 218, 221, 222.

${ }^{116}$ Ibid., 220.
} 
group of people inspired by the vision of a better world who actually attempt to do something about it." 117

Although the clearest examples of communitas are tragic instances of a country assailed by a natural disaster or a group being persecuted, attacked by terrorists, or in war, Hirsch sees similar patterns in sport teams, adventure camps, and short-term missions. In these circumstances, a number of people become a team around a common challenge with shared work practices to do something that could not be done by themselves individually. Although danger and crisis is often connected with environments of comradeship, Hirsch acknowledges that developing a vigorous transformative vision can also create communitas. Applying this idea to Christianity, Hirsch suggests that many expressions are missing a communitas experience because they do not have the missionary component that adds the liminality element by taking people out of their comfort zones as they engage with the world. As the people of God, compared to a body and a living system, Christians are moved by a vision of the future. In contrast, a closed and artificial system without adaptability and variety deteriorates toward equilibrium, which means death. ${ }^{118}$ Thus, his proposal is the adoption of mission as the organizing principle, around which everything else would be structured:

To preserve the movement ethos of God's people, it is fundamental that the church keeps mission at the center of its self-understanding. Without mission there is no movement, and the community dies a death of the spirit long before it dies a physical

\footnotetext{
${ }^{117}$ Hirsch, The Forgotten Ways, 221. The initiation rituals of young boys in many tribes across Africa and the sense of comradeship and communality as a result of it is described as an example of communitas in Hirsch and Altclass, The Forgotten Ways Handbook, 170.

${ }^{118}$ Ibid., 224, 230-233. "When we are caught up into it, and pursue it, we are changed, and we go on to enact history." Ibid., 234.
} 
death. To forget mission is to forget ourselves; to forget mission is to lose our raison d'être and leads to our eventual demise. ${ }^{119}$

\section{Disciple Making}

Disciples making, the last element of this model, is considered by Hirsch the "most critical" and the "strategic" one since this is the "essential" and "irreplaceable" task of the church. Hirsch calls the capacity to generate authentic followers of Jesus "the single most crucial factor" that affects all other elements of the Christian ethos.

Discipleship follows the example of Jesus who invested His life in developing His followers into disciples. It is primarily about a relationship with Jesus, therefore, not limited to the intellectual dimension, but to every dimension of life. ${ }^{120}$ In terms of Christian movements, Hirsch points out that, "at the most uncomplicated level, they appear to the observer simply as disciple-making systems." 121

The concept of disciple making is defined by Hirsch through four complementary characteristics: Christlikeness, embodiment, spiritual authority, and leadership. Christlikeness emphasizes the essence of becoming like Jesus with a focus on His commission. Embodiment relates to the translation of the gospel into "concrete life" in "profoundly relational and attractive" fashions. It involves an authentic way of living, a patterning, and a modeling of the message, which is essential for the transmission of the

\footnotetext{
${ }^{119}$ Hirsch, The Forgotten Ways, 237. "If evangelizing and discipling the nations lie at the heart of the church's purpose in the world, it is mission, and not ministry, that is the true organizing principle of the church. . . But the church that aims at mission will have to do ministry, because ministry is the means to do mission." Ibid., 236.

${ }^{120}$ Ibid., 24, 102, 113. Hirsch suggests that discipleship is "always articulated and experienced over against all other competing claims for our loyalty and allegiance.” Ibid., 106.

${ }^{121}$ Ibid., 103.
} 
gospel and the fostering of Christian movements. Leadership highlights the relationship between leaders and followers while aiming at transforming followers into leaders. ${ }^{122}$ Following that reasoning, Hirsch points out that the broadness of a movement's leadership base determines the reach of any movement and "the quality of the church's leadership is directly proportional to the quality of discipleship." 123

It is equally important for Christian movements to survive beyond their initial stages and that its Founder lives on in His disciples - the gospel takes root in their lives and they become the gospel to the people around them. Hirsch points out that "in the final analysis, the medium is the message, and the phenomenal movements of God seemed to be able to express the message authentically through the media of both their personal and common lives together. This is what made it believable and transferable." ${ }^{124}$

In order to strengthen his arguments, Hirsch also suggests what discipleship is not: (1) the first step of a long journey as it is the journey itself and (2) the intellectual assimilation of ideas. Two realities have particularly impacted the understanding of discipleship in a negative way: the development of nominal Christianity during Christendom and the false expectations and shallow relationships as a consequence of the phenomenon of consumerism. ${ }^{125}$

\footnotetext{
${ }^{122}$ Hirsch, The Forgotten Ways, 114-117. Hirsch suggests that "Jesus's strategy is to get a whole lot of little versions of him infiltrating every nook and cranny of society by reproducing himself in and through his people in every place throughout the world." Ibid., 113.

${ }^{123}$ Ibid., 119. "Only to the extent that we can develop self-initiating, reproducing, fully devoted disciples can we hope to get the task of Jesus's mission done. . . Leadership, or the lack of it, is a significant key to either the renewal or the decline of the church." Ibid., 119, 120.

${ }^{124}$ Ibid., 114.

${ }^{125}$ Ibid., 103, 104. Hirsch points out that consumerism has communicated the idea that one can consume his or her way into discipleship, which shows that if Christians don't disciple people, the culture
} 


\section{Assumptions of Hirsch's Model}

Hirsch's model of the ethos of Christian missionary movements has received much attention lately. His proposal of core principles as described is based on four assumptions. First, any true group of God's people has everything needed to adapt, witness, and develop in any setting. ${ }^{126}$ This view is derived from the understanding that God's people have received the gospel and the Holy Spirit, and that is sufficient and powerful enough to reach and transform people of any culture.

Second, recovering a genuine movement ethos is essential to restoring the dynamism of important Christian movements. "It is by recovering a genuine movement ethos that we can restore something of the dynamism of significant Jesus movements in history." ${ }^{\prime 27}$ Hirsch's restorationist view is founded on the assumption that what Jesus began should yield dynamic missionary movements. If that is not the case among Christian movements today, it is at least in part because they have missed some essential aspects of Christianity.

Third, organic systems should inform the structure of Christian movements. Hirsch clarifies his position in the introduction of The Forgotten Ways pointing out that "structures are absolutely necessary for cooperative human action as well as for maintaining some form of coherent social patterns." ${ }^{\text {"28 }}$ Along those lines, it is clear throughout his work that he holds a fierce criticism of overinstitutionalization. Hirsch

will. So he believes that consumerism as fostered by advertising is "the major threat to the viability of our faith." Hirsch, The Forgotten Ways, 106-111.
${ }^{126}$ Ibib., 183.
${ }^{127}$ Ibid., 22.
${ }^{128}$ Ibid., 23. 
emphasizes that "there needs to be a clear distinction between necessary organizational structure and institutionalism," which he has come to see as a hindering obstacle to the engagement of God's people in mission. Furthermore, it is one of Hirsch's footnotes that best express his view of institutionalism.

We can observe from history that through the consolidation and centralization of power, institutions begin to claim an authority that they were not originally given and have no theological right to claim. It is at this point that the structures of ecclesia become somewhat politicized and therefore repressive of any activities that threaten the status quo inherent in it. This is institutionalism and historically it has almost always meant the effective expulsion of its more creative and disparate elements.... This is not to say that there does not appear to be some divine order (structure) given to the church. But it is to say that this order is almost always legitimized directly through the community's corporate affirmation of calling, personal character, charismatic empowerment, and spiritual authority. It always remains personal and never moves purely to the institutional. Our role model need be none less than our Founder. It seems that only he can wield significant power without eventually misusing it. ${ }^{129}$

In terms of solution, Hirsch suggests a rather balanced view: instead of assuming an "anarchic," "political," and "anti-institutional" position, one should seek to recover the nature of organic systems. Moreover, "rather than thinking of the early church as noninstitutional, we need to think of it rather as 'preinstitutitonal."'130

Fourth, intercultural mission methodology should be followed in every context. Hirsch does not make a distinction between mission contexts in the West or in other places. His assumption is that the Christendom mode of mission is not adequate to the challenge presented today, since even the West demands more of a "cross-cultural

\footnotetext{
${ }^{129}$ Hirsch, The Forgotten Ways, 23.

${ }^{130}$ Ibid., 185.
} 
missionary methodology." ${ }^{131}$ Ralph Winter's cultural distance concept ${ }^{132}$ becomes helpful to analyze the current cultural barriers and Hirsch concludes that "the time has come in the West to learn that all our attempts to communicate the gospel are now crosscultural." $" 133$

${ }^{131}$ Hirsch, The Forgotten Ways, 34.

${ }^{132}$ Ralph Winter describes the E-scale and the P-scale as the cultural distances "that Christians need to move in order to communicate the gospel" and "that potential believers need to move in order to join the nearest church," respectively. Ralph D. Winter and Bruce A. Koch, "Finishing the Task: The Unreached Peoples Challenge," in Perspectives on the World Christian Movement: A Reader, ed. Ralph D. Winter and Steven C. Hawthorne (Pasadena, CA: William Carey Library, 2009), 532.

${ }^{133}$ Hirsch, The Forgotten Ways, 58. 


\section{CHAPTER 6}

\section{THE ETHOS OF THE SEVENTH-DAY ADVENTIST MOVEMENT}

After reviewing Hirsch's model, one is presented with the question about its applicability to the Seventh-day Adventist movement. As Hirsch acknowledges in a footnote, ${ }^{1}$ one may feel the need to adapt his model for the analysis of a particular movement.

As one studies the Adventist movement, one will identify the same stages of the cycle of religious movements. One of the suggestions of this study is the need to understand, recover, and foster the ethos of movements found in the first stage. Social studies also indicate a close relation between cognitive, affective, and evaluative themes in a group's worldview. Thus, in a Christian movement, beliefs and ethos should reflect and shape each other.

This section will focus on describing the character and dynamics of the Adventist movement in the beginning stage. Identity and mission will be given special consideration. In order to progress toward a model of Adventist movement ethos, the Adventist distinctive beliefs will be described. Elements of continuity and discontinuity with Adventist Protestant origins will be helpful in order to develop a more meaningful relation to Hirsch's model as well as the relation between those beliefs and Adventist

${ }^{1}$ Hirsch, The Forgotten Ways, 24. 
missionary understanding. The final part will suggest a model of Adventist movement ethos.

\section{The Rise of Adventism}

The world in which Adventism began, in the early years of the nineteenth century, was characterized by a great spiritual awakening. That feature was expressed in the diversity of movements such as the Shakers, the Universalists, the Unitarians, the beginning of the Church of Latter-day Saints (organized in 1830), the rise of spiritualism in America, and a missionary movement stimulated in a large way by Finney and the establishment of Bible societies, the Sunday School Movement, the Industrial Revolution that changed economic conditions, reform movements including the educational reform, feminist reformers, health reform, and those working for the abolition of slavery, the new age in travel and communications due to the use of steam and electricity, and the firm commitment to democracy. ${ }^{2}$

Seventh-day Adventists believe that their roots in history go back a long way. Back, not only to the Milerite movement of the 1830s and 40s, but farther: to Wesley and the eighteenth century Evangelical revivalists, to the great Protestant Reformers and to such earlier dissenting groups as the Lollards and Waldenses. Back to the primitive Celtic Church of Ireland and Scotland, the persecuted church of the first three centuries after Christ, back to Christ and the apostles themselves. Yet it is obvious that modern Adventism developed in the setting of the great advent awakening which took place in the early years of the nineteenth century. ${ }^{3}$

More specifically, the Seventh-day Adventist movement was born out of

\footnotetext{
${ }^{2}$ Richard W. Schwarz, Light Bearers to the Remnant: Denominational History Textbook for Seventh-day Adventist College Classes (Mountain View, CA: Pacific Press, 1979), 13-22. Parts of the Bible were translated into 112 languages and dialects between 1800 and 1844. Ibid., 17.

${ }^{3}$ Ibid., 13. Bryan Ball argues that the Adventism has deep roots in the biblical Protestantism of seventeenth-century England, especially within the Puritan movement, rather than being a later by-product of radical millenarianism. B. W. Ball, The English Connection: The Puritan Roots of Seventh-day Adventist Belief, 2nd ed. (Cambridge, England: J. Clarke, 2014).
} 
Millerism, an advent movement named after its main leader, William Miller. Miller, a prosperous farmer and a Baptist lay preacher of northern New York state, devoted himself to the study of the prophecies of Daniel, especially Daniel 8:14, and concluded that Christ's second coming would take place around the year 1843. Through publications, conferences, and camp meetings a great advent awakening grew from a regional to a national movement throughout the United States. After a few different date setting attempts, Millerites finally arrived at October 22, 1844, as the day for the fulfillment of the Daniel 8:14 prophecy. On the fatidic day Adventist groups, as many as one hundred thousand, waited in expectation of a cloud of light, but that prediction did not come true and a great disappointment was the result. Many members and leaders of the movement gave up on their beliefs, but some sought to reinterpret that happening. One group developed into the Evangelical Adventists with close ties to major Protestant churches and a tendency toward a belief in a premillennial advent. Another group became the Advent Christian Church and believed that the millennium was in the past. A third group came to the understanding that the mistake in their interpretation of the 2300-day prophecy was related to an event that took place and not to time. They became known as the Sabbatarians and formed the Seventh-day Adventist Church. ${ }^{4}$

Major works have been devoted to the study of the overall history of the Millerites, ${ }^{5}$ but of special interest for this dissertation is the ethos of this movement and

${ }^{4}$ Schwarz, Light Bearers to the Remnant, 37-58.

${ }^{5}$ See Sylvester Bliss, Memoirs of William Miller: With Appendices Containing Three Other Contemporary Biographical Sketches, Adventist Classic Library (Berrien Springs, MI: Andrews University Press, 2005); Ronald L. Numbers and Jonathan M. Butler, The Disappointed: Millerism and Millenarianism in the Nineteenth Century, 2nd ed. (Knoxville: University of Tennessee Press, 1993); David L. Rowe, God's Strange Work: William Miller and the End of the World, Library of Religious Biography 
its relation to one of its offshoots, the Seventh-day Adventist Church.

\section{Identity and Mission}

The character of Millerism was shaped by its leaders as "a rational, cool-headed religion that was more cognitive than emotional." 6 The foundation of its central belief and major preaching thrust, the coming of Jesus, was the result of Bible study and as such it was presented to everyone. Bible verses were read, connected, and explained in order to show that Old Testament prophecies pointed to the return of Jesus in 1844 . That rational aspect of Millerism was compatible with its objective of shedding new light on that subject in the Protestant world. Miller did not see his doctrine as sectarian as he believed it belonged to all denominations. "Pre-1845 Millerism was not a denomination. Rather, it was an ecumenical movement composed of ministers and laypeople from all the evangelical denominations."7 Nonetheless, the movement resulting from that new understanding, especially as it faced divergent religious traditions after October 22, 1844, became divisive and led to the formation of a new sect.

After the disappointment, the movement was forced to review its identity and mission during the decisive following months and years. Disorientation and disarray were part of the mood and structure of Millerite Adventism at that stage. The presence of

(Grand Rapids, MI: William B. Eerdmans Pub. Co., 2008); Francis D. Nichol, The Midnight Cry: A Defense of the Character and Conduct of William Miller and the Millerites, Who Mistakenly Believed That the Second Coming of Christ Would Take Place in the Year 1844 (Brushton, NY: TEACH Services, 2000); Everett Dick and Gary Land, William Miller and the Advent Crisis, 1831-1844 (Berrien Springs, MI: Andrews University Press, 1994).

${ }^{6}$ Knight, William Miller and the Rise of Adventism, 149.

${ }^{7}$ Ibid., 196. 
elements from the radical fringe and an evident spirit of freedom of thought, opinion, and speech surfaced as significant influences. Miller, the Baptist, and other restorationist traditions were part of the background of many followers. ${ }^{8}$

While part of that search for identity was related to sorting out their beliefs, as pointed out in the previous section, an equally important related resolution had to do with the definition of their mission. The early years were characterized by what came to be known as the shut door theory. The combination of the parable of the bridesmaids and the understanding of the closing of probation time shortly before the advent was applied to what had happened in October 1844. This led to the belief that there was no possibility of salvation for those who had not accepted their message, therefore, there was no need for evangelization. ${ }^{9}$ There was a major shift in emphasis from evangelism to holding the movement together. "Millerite activity now focused on inreach as the disoriented believers sought to make sense out of their experience and to create wholeness and continuity in their ranks. ${ }^{" 10}$ Eventually the leaders of the Adventist movement realized

\footnotetext{
${ }^{8}$ Knight, William Miller and the Rise of Adventism, 209. Knight points out that Millerism and, consequently, Adventism, followed the historical pattern of as millennial movements and attracted some "on the radical edge who get carried away by the excitement and are quick to identify esoteric 'new truth" and to pronounce those who do not agree with them as both apostate and Babylon." There are two important lessons from Adventism's radical fringe: "the spirit of the radicals lives on among some of the more stable descendants of Millerism" and "all other Adventists were forced to define themselves in terms of the radical wing. The task was not only one of defining but also one of distancing themselves from the 'fanatics'." Ibid., 226, 227. "As a result, early 1845 saw a rather open discussion in the press on many of the issues that divided the advent believers." Ibid., 200.

${ }^{9}$ Schwarz, Light Bearers to the Remnant, 55.

${ }^{10}$ Knight, William Miller and the Rise of Adventism, 186. "On November 18, 1844, Miller wrote a letter displaying confidence in the end of the world before the end of that year and also claiming that "the door of human probation had been shut and that the Adventists' work in warning the sinful world was complete. Their only evangelistic function was to work for the confused Adventists in their ranks." Ibid., 192.
} 
their worldwide mission. "This had a significant impact on the understanding of the nature of the Adventist church." 11

The acceptance of the shut door belief was related to the fulfillment of the 2300day prophecy of Daniel 8:14 as being the return of Jesus in October $1844 .{ }^{12}$ Logical and practical arguments revealed the inconsistence of the shut door belief, especially after the new understanding of the event that had taken place in October 22, 1844. On the one hand, "if there was no fulfillment of prophecy, there could be no shut door-and vice versa" and on the other hand, "probation could not be over because souls were being converted."13 That conviction that God had been leading them played an important role in giving the movement a renewed identity and a worldwide evangelistic and missionary thrust defined in major ways by "a new divine imperative to preach the Sabbath and the third angel's message of Revelation 14 'to every nation, and kindred, and tongue, and people." "14 Their renewed sense of worldwide mission seems to have temporarily motivated leaders like Himes who went to Britain on June 1, 1846, with two others to

\footnotetext{
${ }^{11}$ Ángel Manuel Rodriguez, Toward a Theology of the Remnant: An Adventist Eclesiological Perspective (Silver Spring, MD: Biblical Research Institute, 2009), 21.

${ }^{12}$ For more on the shut-door experience and missiology, see Borge Schantz, "The Development of Seventh-day Adventist Missionary Thought: Contemporary Appraisal" (PhD, Fuller Theological Seminary, 1983), 212-221.
}

${ }^{13}$ Knight, William Miller and the Rise of Adventism, 201, 204. A third factor that helped groups correct their missiological understanding was Ellen White's visions with clear indications of a mission with a much broader scope. Alberto R. Timm, "The Sanctuary and the Three Angels' Messages, 1844-1863: Integrating Factors in the Development of Seventh-day Adventist Doctrines" (PhD, Andrews University, 1995), 221.

${ }^{14} \mathrm{Knight}$, William Miller and the Rise of Adventism, 262, 266. For more on the dawning awareness of world mission, see Schantz, "The Development of Seventh-day Adventist Missionary Thought," 232236. 
hold conferences, distribute literature, and establish a publishing ministry. ${ }^{15} \mathrm{New}$ members were very active and zealous in propagating their new-found faith and making this a missionary, lay Adventist movement. ${ }^{16}$ As Knight points out "the genius of the Sabbatarian solution was that it had captured the dynamics of Millerism and had found a way to extend and prolong those dynamics." 17

The conference in Albany, which began on April 29, 1845, became a turning point in Adventist history. One of the major accomplishments of that conference was the development of a plan of action including the typical Millerite approaches for sharing the gospel: preaching services/series of conferences, literature distribution, Sunday schools, and Bible classes. A specific remark about publications by Knight points out their importance for this plan, which aimed at clarifying their identity and defining their mission. The Review and Herald was the 'the church' and gave a sense of belonging to them since they did not have church buildings in the first years and were scattered. The primary goal was calling out, informing, and uniting a body of confused believers. ${ }^{18}$ Thus, in practice, publications also had an important role in the Millerite understanding of organization.

Publications eventually proved not to be effective enough for organization. The major obstacle in terms of formal denominational organization came from previous

\footnotetext{
${ }^{15}$ Knight, William Miller and the Rise of Adventism, 238. Himes returned in 1847. Only in 1865 another missionary, M. B. Czechowski, was sent to Europe.

${ }^{16}$ Schantz, “The Development of Seventh-day Adventist Missionary Thought,” 225.

${ }^{17}$ Knight, William Miller and the Rise of Adventism, 270.

${ }^{18}$ Ibid., 231, 271-274.
} 
frustrations experienced by Millerite leaders with the organizations that had silenced them and cast them out of their own churches. Storrs, a Methodist leader of Millerism, was probably the most vocal about his opposition to church organization and doctrinal creeds. He believed that believers should be held together by bonds of love. In 1844 he wrote that "no church can be organized by man's invention but what it becomes Babylon the moment it is organized."19

The most important Sabbatarian pro-organization leader was James White. His arguments focused on organization as part of God's plan to meet the needs of His people. In May 1863, after the majority had been convinced that some sort of organization was necessary, the General Conference of Seventh-day Adventists was formed with John Byington as its first president. ${ }^{20}$

God did not design to bring his people out of the confusion of Babylon into the greater confusion of no order nor discipline. This would only be making a bad matter worse. His object in bringing them out from the churches was to discipline and unite them for the last great battle of truth under the third message. It was not ambition to build up a denomination that suggested organization, but the sheer necessities of the case. $^{21}$

Out of the Millerite experience, among the different Adventist groups that sprang up, Seventh-day Adventists became the largest. After almost 170 years, the Seventh-day

\footnotetext{
${ }^{19}$ Schwarz, Light Bearers to the Remnant, 47. "The legacy of Storrs on church organization would live on to frustrate the several Adventist bodies for decades in the post-1844 period." Knight, William Miller and the Rise of Adventism, 165.

${ }^{20}$ Knight, William Miller and the Rise of Adventism, 275. The first official Adventist statement of beliefs (May 1845) "was an important step in the institutionalization of Adventism at a moment when no one felt the need of starting a new church." Fortin, "Nineteenth-Century Evangelicalism and the Adventist Statements of Beliefs," 53.

${ }^{21}$ James White, Life Incidents (Battle Creek, MI: Steam Press: Seventh-day Adventist Publishing Association, 1868), 199.
} 
Adventist Church has more than 18 million members worldwide. ${ }^{22}$ Knight suggests that there was a close identification between the character of both the Millerite and the Seventh-day Adventist movements and he makes reference to three complementary views of that ethos. David L. Rowe suggests that Millerism combined revivalism as the method for spreading its message, millennialism as future orientation and direction, and pietism with its devotional faith to respond to revivalism and as a balance for millennialism. Michael Barkun points out the importance of their contexts characterized by individual and collective distress and the solution offered based on hope in God's promises. And Ruth Alden Doan singles out Millerism's alignment with orthodoxy in its view of the Bible and church and its unique view of the premillennial advent. ${ }^{23}$

In the most comprehensive analysis of the character of those movements, however, Knight points out four internal factors. First, the combination of the rational aspects of its doctrines and emotionalism, which was also bounded by rationality, gave life and stability, while making it appealing. "Seventh-day Adventism has partaken of much of that same balance, although it appears at times to wander too far toward the purely rational pole. . . Typically both have aimed at converting people to "the truth.",24 Second, their holistic view of truth, which included a content/doctrinal factor connected to lifestyle expressions. Millerism had a message to preach and Seventh-day Adventists also developed a system of unconventional beliefs that became the foundation of their

\footnotetext{
${ }^{22}$ General Conference of Seventh-day Adventists, Annual Statistical Report (2015) (Silver Spring, MD: General Conference, 2015), 4.

${ }^{23}$ Knight, William Miller and the Rise of Adventism, 279, 280.

${ }^{24}$ Ibid., 281.
} 
mission. The uniqueness of the group was not only in terms of doctrines but also lifestyle, which led to "bridge-burning acts," counter-cultural aspects of a way of living in a subculture. Knight cites Hewitt's observation about the importance of those distinctive beliefs and practices in giving "its faithful members a resoluteness of individual and group character that goes far to explain their successes." ${ }^{25}$ Third, it developed a dynamic organizational structure to carry on its mission. The lack of sufficient organization was at least partly responsible for the disappearance of the other groups that developed after the Millerite movement. Seventh-day Adventists were able to mobilize for united action. Their "structure was consciously designed with mission outreach in mind."26 Fourth, it had a prophetic mission and sense of urgency. These last two elements derived from a prophetic understanding that allowed it to be a mission-driven movement. "From their beginning, the Sabbatarians never viewed themselves as merely another denomination."27

\footnotetext{
${ }^{25}$ Knight, William Miller and the Rise of Adventism, 282. "The apocalyptic piety of Seventh-day Adventists was nurtured by the worldview that had been created by their historicist hermeneutic of the apocalyptic Scriptures. It will thus be pointed out that a historicist reading of the Bible in general and of biblical prophecy in particular creates a corresponding worldview, which, in turn, shapes one's spirituality. ... Adventists believed that the apocalyptic Scriptures presented a divinely outlined world history which was thus under God's absolute control. According to this outline, the world as society, culture, and nature, was rapidly deteriorating in all respects and thus coming to its cataclysmic End." Zoltan Szalos-Farkas, "An Exploration of the Rise and Development of Seventh-day Adventist Spirituality: With Special Reference to the Charismatic Guidance of Ellen G. White, 1844-1915" (PhD diss., Aberdeen University, 2004), v.
}

\footnotetext{
${ }^{26}$ Knight, William Miller and the Rise of Adventism, 283. In the late 1840s, leaders of Albany Adventists faced the challenge of "mission outreach and the need for some sort of organizational structure to facilitate that outreach." Ibid., 238. One of the Albany denominations, the Advent Christian Association was established in 1860, despite strong antidenominational feelings. It even refused to use the word "denominational." Paradoxically, it is their weak administrative structure that has been blamed by the denomination's lack of growth.

${ }^{27}$ Ibid., 284. That has been a difference between Seventh-day Adventists and other offshoot groups. As Knight mentions, one Seventh Day Baptist preacher once remarked that his church had been able "convince people of the legality of the Seventh-day Sabbath, but they could not get them to move as the Sabbath Adventists did." Similar observation is mentioned about another group, the Advent Christians
} 
As Barry Oliver points out, "There was a sense of great expectation and vibrant enthusiasm about the mission of the church — the kind of enthusiasm that was characteristic of many young denominations. ${ }^{28}$ They saw themselves as a prophetic people in two areas: they thought their movement and message was a fulfillment of prophecy and they believed their prophetic movement and message should reach the entire world before Jesus returned. That vision helped mobilize people in missionary efforts, which answers the question "Why did those early Adventists sacrifice their means and their children to mission?"29

After the experience of October 1844, the Adventist movement gradually began the process of institutionalization. "Millerite groups took, unconsciously at first, various steps toward the institutionalization of Adventist denominations." ${ }^{30}$ The reasoning behind the organization of the Seventh-day Adventist Church in 1863 were legitimate and aimed at efficiency to accomplish the missionary task. "Similar motives lay behind the development of the complex system of publishing houses, schools, and medical institutions their spiritual descendants built in the years that followed." ${ }^{31}$ In addition to the growing systems of institutions, Moberg believes that "the gradual acceptance of

which have not made much of an impact on the world because of its smallness "in dreams, in visions. Smallness breeds smallness.” Ibid., 286.

${ }^{28}$ Barry David Oliver, "Principles for Reorganization of the Seventh-day Adventist Administrative Structure, 1888-1903: Implications for an International Church" (PhD diss., Andrews University, 1989), 44.

\footnotetext{
${ }^{29}$ Knight, The Apocalyptic Vision and the Neutering of Adventism, 15.

${ }^{30}$ Fortin, "Nineteenth-Century Evangelicalism," 51.

${ }^{31}$ Schwarz, Light Bearers to the Remnant, 628.
} 
Seventh-day Adventist into fundamentalist circles illustrated the movement into denominational status in this period." 32

In recent years, however, the warning has been given in relation to the next stage in the cycle of organizations. Some believe the Adventist organization is facing the threat of losing its relevance, thus repeating the experience of previous religious movements. "Time after time the world has witnessed vibrant reformatory religious movements harden and lose their vitality with age."33

Some of the reasons for this concern include (1) the "seemingly ever delayed end of the world" that leads some believers to spiritualize the nature of Christ's advent; (2) affluence and upward mobility present among many second and third generation Adventist families that have diminished some of the desire for the consummation of God's kingdom; (3) the challenge of keeping a balanced emphasis between the unique doctrines and those shared with other Christians; (4) an organizational structure that is less focused for mission, for as the structure expanded so did a bureaucracy that is expensive, dysfunctional, and inefficient for world mission in the twenty-first century; and (5) finally, the temptation to give up on Adventism's vision and prophetic mission. ${ }^{34}$

\footnotetext{
${ }^{32}$ Moberg, The Church as a Social Institution, 121. Oliver points out that by 1903, A. G. Daniells, then president of the General Conference, believed ecclesiology was a function of eschatological and missiological perceptions. The church existed because of a specific missionary task. The reason for an organization was not primarily because the end of the world, but because the church had a task to accomplish, that defined both the church's modus operandi and its raison d'etre - the church was mission. There was a clear functional view of the nature of the church. Oliver, "Principles for Reorganization of the Seventh-day Adventist Administrative Structure, 1888-1903: Implications for an International Church," 241, 244, 254.
}

${ }^{33}$ Knight, The Apocalyptic Vision and the Neutering of Adventism, 287.

${ }^{34}$ Ibid., 288-290. "Seventh-day Adventism . . . is facing major organizational problems as it enters the twenty-first century." Knight, William Miller and the Rise of Adventism, 283. 
More than a century and a half later, the Seventh-day Adventist Church faces the challenges of an aging denomination. Although the church has reached the stage of institutionalization, it has struggled to keep a movement ethos. This is not a recent concern since early Adventist leaders discussed its identity and character, as mentioned in the previous section. The concern to maintain a movement ethos is, to some extent, embedded in the very nature and self-conception of the Adventist Church. ${ }^{35}$

\section{Adventist Beliefs}

The ethos and theological basis of Millerism was indireclty shaped by evangelicalism through the denominations Miller and other leaders were associated with. Denis Fortin has pointed out studies that have shown elements of continuity and discontinuity between Millerism, and thereafter Adventism, with nineteenth-century evangelical Protestantism and revivalism in the first three decades of the new movement. Millerism had "the same religious characteristics and ethos as antebellum evangelicalism" but Adventism "was much more than just a religious movement with a basic worldview similar to that of evangelical denominations within popular American culture." Fortin's comparison of the three first Adventist statements of beliefs (written between 1845 and 1872), concludes that "in fact, some segments of Adventism clearly stood on the fringes of evangelicalism and thought of themselves as nonevangelical." ${ }^{36}$

Adopting Ruth Doan's paradigm of four defining elements - the new birth

\footnotetext{
${ }^{35}$ See David Tallmadge Arthur, "“Come out of Babylon': A Study of Millerite Separatism and Denominationalism, 1840-1865" (PhD diss., The University of Rochester, 1970) for a longer discussion about the struggle to organize among Millerites.

${ }^{36}$ Fortin, "Nineteenth-Century Evangelicalism," 52.
} 
experience, the centrality of the Bible to shape its message, mission, and the millennium - evangelicalism in the nineteenth century could be summarized as a process in which the "individual needed conversion, and the message of the gospel had to be spread. The end result would be a glorious age of peace and harmony under the rulespiritual or physical—of Jesus Christ." Therefore, as Fortin underlines, it was "viewed more as a religious temperament than as a theological system." ${ }^{\prime 37}$

In terms of Adventism, the same broad religious perspectives, ethos, and temperament were reflected. The new birth experience was evident in early Adventist soteriology and was influenced by Arminianism and Pietism. The centrality of Scripture is clearly identifiable in Adventist statements of beliefs (and the direct in-text quotations as part of the text) as the movement, following William Miller's emphasis, continued to be based on the Bible. The missionary aspect of evangelicalism was also transferred to Adventism with its soteriological basis, but also with an added eschatological dimension. Finally, despite a premillennialist message, Adventists also reflected the evangelical focus on the millennium. ${ }^{38}$

Fortin furthered his comparison between Adventism and evangelicalism by adding specific theological categories. His intent was to identify the evangelical influence in early Adventist theology by comparing the Basis of Evangelical Alliance (1846), a statement of beliefs that reflects evangelicalism of the time, and three Adventist documents. He concluded that, over time, it became very evident that despite basic

\footnotetext{
${ }^{37}$ Fortin, "Nineteenth-Century Evangelicalism," 55.

${ }^{38}$ Ibid., 58.
} 
evangelical theological roots, Seventh-day Adventists had different understandings in terms of the state of the dead (Albany Statement, 1845), the eschatological emphasis (Evangelical Adventist Statement, 1869), and the sanctuary and the progressive work of Christ's atonement as a distinct theology center (Seventh-day Adventist Statement, 1872). Fortin's conclusion supports the understanding that "Seventh-day Adventists shared basic evangelical theological roots and, at the same time, showed important theological differences with evangelicalism."39

After the disappointment, the understanding about what had happened was crucial especially for the Sabbatarians.

While the majority of Millerite Adventists . . looked back on the time element in their interpretation of the 2300-day prophecy of Daniel 8:14 as an error, Sabbatarians held that the Millerites had been correct on the time but wrong as to the event to take place on October 22, 1844. . . Their new sanctuary doctrine not only explained their disappointment, but it also provided a theological framework that enabled the Sabbatarians to press into the future with certainty. ${ }^{40}$

As Alberto Timm points out, that belief system of early Sabbatarians, developed in connection with Evangelicalism through Millerism's influence, revealed the following characteristics: (1) a biblical foundation, (2) a historicist prophetic interpretation, (3) eschatological time-setting, (4) a cosmic-controversy framework, (5) a Christcentered focus, (6) historical continuity, (7) a present-truth emphasis, and (8) a mission

\footnotetext{
${ }^{39}$ Fortin, "Nineteenth-Century Evangelicalism," 67. For further discussion on the struggle for balance, between overemphasizing the continuity or discontinuity aspects of Seventh-day Adventistm, in the historical development of Adventist theology, see George R. Knight, A Search for Identity: The Development of Seventh-day Adventist Beliefs, Adventist Heritage Series (Hagerstown, MD: Review and Herald, 2000).

${ }^{40}$ Knight, William Miller and the Rise of Adventism, 262. Timm presents the belief about the sanctuary as having an integrating function in the development of Sabbatarian Adventist doctrinal system. Timm, “The Sanctuary and the Three Angels' Messages, 1844-1863,” 188.
} 
concern. In the initial years of the Sabbatarian movement, mission was primarily understood by that group in terms of restoring Bible truth and preparing other exMillerites for the soon coming of Christ. ${ }^{41}$

\section{Adventist Beliefs and Mission}

In the last 160 years, since the Millerite disappointment, Adventist beliefs and mission practices have interacted and helped shape each other. Although most distinctive Adventist beliefs were already part of the movement by 1850 and were further developed in the 1850 s and early $1860 \mathrm{~s},{ }^{42}$ their missiological understanding experienced major developments. The Adventist movement transitioned from the Shut Door theory to a worldwide mission understanding. Knight has suggested a progression through five stages. Phase one, the antimission people (1844-1850) was related to the Millerite beliefs about the prophetic fulfillment in 1844 and the shut door theory. Phase two, a partially opened door (1850-1874), reflected a position of no responsibility for mission. Phase three, mission to the Christian nations (1874-1889), was a time when Adventists believed their mission was to present the distinctive doctrines to those who were already Christians. Phase four, mission to the World (1890-1960s), marked the expansion of Adventist missions and membership outside North America. Phase five, mission with conscious intent (1960s-present), represents a period of specific developments that

\footnotetext{
${ }^{41}$ Timm, “The Sanctuary and the Three Angels’ Messages, 1844-1863,”170, 186.

${ }^{42}$ See chapters 3 and 4 in Timm, "The Sanctuary and the Three Angels' Messages, 1844-1863," $170,186$.
} 
included academic programs and integration of some departments toward the fulfillment of Adventist mission. ${ }^{43}$

Today, Adventist mission, which has been traditionally conceived of in terms of a prophetic mission, is defined in the church's mission statements as the need "to proclaim to all peoples the everlasting gospel in the context of the three angels' messages of Rev 14:6-12, leading them to accept Jesus as personal Savior and to unite with His church, and nurturing them in preparation for His soon return." 44

Adventists believe that this everlasting gospel is the same gospel which Jesus, the apostles, and the Early Church preached and should be preached around the world in these last days. Throughout the history of Christianity the gospel has been emphasized and applied differently in specific contexts and has been "present truth" 45 to the people who received it. Because Adventists understand that earth's history is in the last days, in the time of God's judgment, and Jesus' return is imminent, they have a special message for the "time of the end." 46 Thus, this is the apostolic gospel, "understood and

\footnotetext{
${ }^{43}$ Knight, The Fat Lady and the Kingdom, 58-78.
}

${ }^{44}$ Communication Department, General Conference of Seventh-day Adventists, Statements, Guidelines \& Other Documents, 4th exp. ed. (Hagerstown, MD: Review and Herald, 2010), 1. The Adventist message is simply "the everlasting gospel in the setting of God's great judgment hour, the imminent second coming of our Lord, and the preparation of men to meet God." George R. Knight, Seventh-day Adventists Answer Questions on Doctrine, Annotated ed., Adventist Classic Library (Berrien Springs, MI: Andrews University Press, 2003), 90.

\footnotetext{
${ }^{45}$ Adventists use this term for the idea of the whole gospel presentation that is time-sensitive. In the last days it means the gospel truth shaped by an emphasis on the three angel's messages of Rev 14 that is at work in people's lives to make evident the work of God's grace. Denis Fortin and Jerry Moon, Ellen G. White Encyclopedia (Hagerstown, MD: Review and Herald, 2013), s.v. "Present Truth."

${ }^{46}$ This expression is a reference to Dan 8:17, 19. Adventists understand that this period of time begins in 1844 concurrent with the beginning of the cleansing of the heavenly sanctuary and in harmony with "the hour of his judgment" of Rev 14:7. Hasel, "Divine Judgment," 839.
} 
emphasized in the setting of God's great last-day judgment hour." ${ }^{47}$

\section{Great Controversy}

The Great Controversy is the term employed by Adventists to refer to the reality of a spiritual battle between Christ and Satan regarding the character of God. All humanity is involved since, by being "observed by the whole creation, this world became the arena of the universal conflict, out of which the God of love will ultimately be vindicated. ${ }^{48}$

As agents sent by the Holy Spirit and engaged in God's mission, believers are not part of a merely human enterprise, but one that has spiritual implications. The real issue is more than belonging to a church, or doing good works. These are elements of a much broader reality as the thirteenth Seventh-day Adventist belief describes:

The universal church is composed of all who truly believe in Christ, but in the last days, a time of widespread apostasy, a remnant has been called out to keep the commandments of God and the faith of Jesus. This remnant announces the arrival of the judgment hour, proclaims salvation through Christ, and heralds the approach of His second advent. This proclamation is symbolized by the three angels of Revelation 14; it coincides with the work of judgment in heaven and results in a work of repentance and reform on earth. Every believer is called to have a personal part in this worldwide witness. (Rev. 12:17; 14:6-12; 18:1-4; 2 Cor. 5:10; Jude 3, 14; 1 Peter 1:16-19; 2 Peter 3:10-14; Rev. 21:1-14. $)^{49}$

\footnotetext{
${ }^{47}$ Knight, Seventh-day Adventists Answer Questions on Doctrine, 480.

${ }^{48}$ Ministerial Association of Seventh-day Adventists, Seventh-day Adventists Believe: A Biblical Exposition of 27 Fundamental Doctrines, 2nd ed. (Silver Spring, MD: Ministerial Association, General Conference of Seventh-day Adventists, 2005), 113.

${ }^{49}$ Ibid., 181. This fundamental belief "places the emphasis on a remnant message to be proclaimed to the world by that part of the end-time remnant already in the church." Knight, The Apocalyptic Vision and the Neutering of Adventism, 78.
} 
The great controversy takes special significance in the last days when the real issue of worship and allegiance, a recurrent theme throughout the Bible and specifically addressed in the law of God, is presented before each human being in order for him or her to make a decision between God and His enemy. As Knight points out the climax of preAdvent history is reached in Rev 14:12 and 14:7, verses that reveal that worship, mentioned eight times in chapters 13 and 14 , is the real issue. ${ }^{50}$

\section{Jesus’ Priestly Ministry}

At the center of the great controversy, Adventists identify the ministry of Jesus Christ. "The heart of the Advent message is Christ and Him crucified" and, therefore, "Christianity is a real experience with Christ. Christianity is a relationship to a Personour blessed Lord and Saviour Jesus Christ." 52 Through faith in the living Christ, Adventists believe that one is saved by grace. A genuine relationship with the Lord and Savior will lead to obedience to His will.

\footnotetext{
50"With the dominance of worship at the center of Revelation 13 and 14, it is clear that the day of worship in the great controversy as reflected in Revelation is merely an outward symbol of total allegiance and true dedication and worship.... If we are going to follow Revelation, we need to move beyond the day to matters of the heart, allegiance, and worship." Knight, The Apocalyptic Vision and the Neutering of Adventism, 77.

${ }^{51}$ Ellen White stated that "the sacrifice of Christ as an atonement for sin is the great truth around which all other truths cluster. In order to be rightly understood and appreciated, every truth in the Word of God, from Genesis to Revelation, must be studied in the light that streams from the cross of Calvary. . . . The Son of God uplifted on the cross. This is to be the foundation of every discourse given by our ministers.” Ellen G. White, Gospel Workers (Washington, DC: Review \& herald, 1915), 315.

${ }^{52}$ Knight, Seventh-day Adventists Answer Questions on Doctrine, 89. "We, as Adventists, definitely believe in doctrine. We hold a unified body of Biblical truth. But that which saves is grace alone, through faith in the living Christ. And similarly, that which justifies is His free and blessed grace. We likewise believe in works, and in full obedience to the will and commandments of God. But the works in which we believe and that we seek to perform, are the result, or fruitage, of salvation, not a means to salvation, in whole or in part." Ibid.
} 
Unlike most Evangelicals, however, Adventists understand that today Christ is active in His priestly ministry in heaven. After Christ's death, resurrection, and ascension, He has been active in an investigative judgment typified by the cleansing on the Day of Atonement in the Hebrew sanctuary. Thus, Christ has been "making available to believers the benefits of His atoning sacrifice offered once for all on the cross," since "this judgment vindicates the justice of God in saving those who believe in Jesus. It declares that those who have remained loyal to God shall receive the kingdom." $" 53$

Although the imminent judgment is a matter of warning, it is not necessarily a matter to cause worry or fear. Adventists highlight the biblical understanding that the Judge is not against His human beings, or even neutral, but in favor of them. Thus, the important matter becomes "whether they have accepted the atoning sacrifice of Christ and let it transform their hearts and minds (1 John 2:1, 2; Rom. 6:1-11; 12:1, 2; 2:4-7)" within the universal dimension of the great controversy, as part of the "justification of God, which is foundational to His justification of those humans who have accepted Christ into their hearts and lives (Rom. 3:25, 36; 1 John 1:9)."54 Those who have accepted Jesus as Savior and Lord can also rejoice in his priestly ministry.

\section{Imminent Second Coming of Jesus}

In connection with the end of the investigative judgment and the rewarding of the saved, the second coming of Christ is described, in Seventh-day Adventist belief twentyfive, as "the blessed hope of the church, the grand climax of the gospel."

\footnotetext{
${ }^{53}$ Ministerial Association of Seventh-day Adventists, Seventh-day Adventists Believe, 347-348.

${ }^{54}$ Knight, The Apocalyptic Vision and the Neutering of Adventism, 71.
} 
The Saviour's coming will be literal, personal, visible, and worldwide. When $\mathrm{He}$ returns, the righteous dead will be resurrected, and together with the righteous living will be glorified and taken to heaven, but the unrighteous will die. The almost complete fulfillment of most lines of prophecy, together with the present condition of the world, indicates that Christ's coming is imminent. The time of that event has not been revealed, and we are therefore exhorted to be ready at all times. (Titus 2:13; Heb. 9:28; John 14:1-3; Acts 1:9-11; Matt. 24:14; Rev. 1:7; Matt. 24:43, 44; 1 Thess. 4:13-18; 1 Cor. 15:51-54; 2 Thess. 1:7-10; 2:8; Rev. 14:14-20; 19:11-21; Matt. 24; Mark 13; Luke 21; 2 Tim. 3:1-5; 1 Thess. 5:1-6. $)^{55}$

Knight suggests that in the synoptic apocalyptic (Matt 24, 25; Mark 13; Luke 21) one finds not so much a description of when the end will happen but how everyone should live in that time. The emphasis is that living the apocalyptic vision in daily life includes living in a state of continual expectancy, urgency, and watchfulness - readiness. "Readiness for the return of Christ does not mean passively waiting for the event. Rather, readiness is responsible activity that produces results for the kingdom of heaven-results that the Master can see and approve of."56

Adventists believe that there are important effects as the result of this understanding in the daily life of the believer, such as hope, love, humility, and holiness. There is no need for any desperation since there is a promise of a better future. Material riches are given temporary importance. Jesus' followers are motivated to develop their moral characters, love more consistently, develop the values of the Kingdom of God, foster a sense of justice, goodness, beauty, and truth. Thus, the waiting time becomes the time for evangelization. This is the time of the Holy Spirit, the time of grace, the time of urgency, and the time of spiritual gifts. The waiting time provides opportunity for the

\footnotetext{
${ }^{55}$ Ministerial Association of Seventh-day Adventists., Seventh-day Adventists Believe, 371.

${ }^{56}$ Knight, The Apocalyptic Vision and the Neutering of Adventism, 94.
} 
Holy Spirit to act on believers, imbuing them with a sense of urgency to employ their gifts in sharing the message of grace. ${ }^{57}$ Knight suggests, therefore, that the motivational force in this apocalyptic emphasis is love rather than fear. It is Jesus, the hope of the world. ${ }^{58}$

\section{Remnant}

The remnant message of Adventists should be about a community that lives out the revelation of God more fully. Being faithful to God's commandments and seeking to live according to His will and covenant during the time of the end in anticipation of Jesus' second coming should make the inaugurated kingdom of God a reality. Three characteristics point to the nature of the remnant: the faith of Jesus, the commandments of God, and the testimony of Jesus.

A faith similar to that which Jesus had is one of the characteristics of God's remnant people. "They reflect Jesus' unshakable confidence in God and the authority of Scripture." ${ }^{59}$ Adventists also believe that God's commandments "express God's love, will, and purposes concerning human conduct and relationships and are binding upon all people in every age. These precepts are the basis of God's covenant with His people and the standard in God's judgment." 60

\footnotetext{
${ }^{57}$ Richard P. Lehmann, "The Second Coming of Jesus," in Handbook of Seventh-day Adventist Theology, ed. Raoul Dederen (Hagerstown, MD: Review and Herald, 2001), 910-911.

${ }^{58} \mathrm{Knight}$, The Apocalyptic Vision and the Neutering of Adventism, 105.

${ }^{59}$ Ministerial Association of Seventh-day Adventists, Seventh-day Adventists Believe, 191.

${ }^{60}$ Ibid., 263. "Correctly viewed, the moral law is much more than a legal code; it is a transcript of the character of God." Knight, Seventh-day Adventists Answer Questions on Doctrine, 105.
} 
God's people should seek to reflect godliness in their relationships with other believers and toward those who do not belong to their faith. Adventists understand that the Bible uses the metaphor of a family to describe the church. This is more than mere socialization, as it includes a spiritual relationship with God and with believers. It implies that people care, love, respect, grow, display unity and individuality, and enjoy and support each other. "It means that each member will have toward other members a love that engenders a deep loyalty that undergirds and strengthens." ${ }^{.61}$

Among the commandments, the celebration of the Sabbath is especially connected with the identity of Seventh-day Adventists, who understand the Sabbath to be "a day of delightful communion with God and one another. It is a symbol of our redemption in Christ, a sign of our sanctification, a token of our allegiance, and a foretaste of our eternal future in God's kingdom." ${ }^{.62}$ It is a time of fellowship for the "highest form of companionship"-companionship with God. Adventists believe that people should experience God's presence among them on that day. "Without the Sabbath all would be labor and sweat without end. Every day would be alike, devoted to secular pursuits. The arrival of the Sabbath, however, brings hope, joy, meaning, and courage." ${ }^{93}$

Adventists define the testimony of Jesus as the spirit of prophecy, a gift of the Spirit to guide the group in understanding, applying, and proclaiming God's message.

\footnotetext{
${ }^{61}$ Ministerial Association of Seventh-day Adventists, Seventh-day Adventists Believe, 169.

${ }^{62}$ Ibid., 281. "We believe that the Sabbath was instituted in Eden before sin entered, that it was honored of God, set apart by divine appointment, and given to mankind as the perpetual memorial of a finished creation.... We understand that the Sabbath was not initially given simply to provide rest from physical exhaustion, but was for man's highest good - spiritually, intellectually, and physically. It was primarily for fellowship with God, inasmuch as it is the presence of God that gives rest and makes holy." Knight, Seventh-day Adventists Answer Questions on Doctrine, 129-130.

${ }^{63}$ Ministerial Association, Seventh-day Adventists Believe, 256.
} 
But that is not the only Spiritual gift found among God's people. God empowers all His children in every age with spiritual gifts for different ministries for the edification of His people. They enable harmony to develop within the church, a living to God's glory 
among the believers, and the growth of the church. In the metaphor of the body of Christ, one finds a model of operation under the indispensable dimension of love, "the greatest of these" (1 Cor 13:13). Organic systems are developed according to the spiritual gifts, with special consideration of the prophetic gifts. ${ }^{64}$ As the body of Christ, the church is $a$ community of faith of which Christ Himself is the Head. "This understanding of the church does not exclude the usefulness of organizational structures, but it describes the church, to be sure, as much more than an institutional phenomenon. It is fundamentally a community of believers." $" 65$

Spiritual gifts emphasize a common ministry, in which clergy and laity work together. "The doctrine of spiritual gifts places the responsibility for the training of the congregation on the shoulders of the minister. God has appointed apostles, prophets, evangelists, pastors, and teachers to equip His people for ministry." ${ }^{\text {"66 }}$ Everyone, however, is endowed to fulfill the mission to the world. Spiritual gifts are "not reward for a job well done - they are tools to do the job well." ${ }^{67}$ Therefore, every believer should use his or her gift to witness both individually and collectively. "The purpose for which God

\footnotetext{
${ }^{64}$ Ministerial Association of Seventh-day Adventists, Seventh-day Adventists Believe, 239-241; 258-259. Adventist belief 17 says that "given by the agency of the Holy Spirit, who apportions to each member as He wills, the gifts provide all abilities and ministries needed by the church to fulfill its divinely ordained functions. ... When members employ there spiritual gifts as faithful stewards of God's varied grace, the church is protected from the destructive influence of false doctrine, grows with a growth that is from God, and is built up in faith and love." Ibid., 237-238.

${ }^{65}$ Ángel Manuel Rodriguez, "Concluding Essay: God's End-Time Remnant and the Christian Church," in Toward a Theology of the Remnant: An Adventist Eclesiological Perspective, ed. Ángel Manuel Rodriguez (Silver Spring, MD: Biblical Research Institute, 2009), 219.

${ }^{66}$ Ministerial Association of Seventh-day Adventists, Seventh-day Adventists Believe, 242.

${ }^{67}$ Ibid.
} 
gives each gift, no matter what it may be, is to enable its possessor to witness." 68

\section{Three Angels' Messages}

Adventists believe that part of living out God's ideals involves intentionally sharing their experience with others so they too can prepare for eternity. As belief 13 points out, "this proclamation is symbolized by the three angels of Revelation 14; it coincides with the work of judgment in heaven and results in a work of repentance and reform on earth. Every believer is called to have a personal part in this worldwide witness." ${ }^{69}$ God's people are "called out of the world to be sent back into the world with a mission and a message."70

The church, the body of Christ, has a purpose assigned by God and exemplified by Christ. Thus, "the church does not merely have a mission, the church is mission." This mission is defined in terms of (1) making disciples of all nations, (2) instructing believers, (3) caring for the needy and suffering, and (4) glorifying God. The primary mission of the church is unquestionably related to sharing the gospel of Jesus Christ and the implementation of God's plan of salvation. Yet its members are invited to learn from the Lord, who though He subordinated physical and other material help to spiritual needs,

${ }^{68}$ Ministerial Association of Seventh-day Adventists, Seventh-day Adventists Believe, 243.

${ }^{69}$ Ibid., 181. As Knight points out, within the overall prophetic understanding, Dan 8:14 is especially significant in Adventism because it is an anchor point in time for the final thrust of world mission. Knight, The Apocalyptic Vision and the Neutering of Adventism, 38.

${ }^{70}$ Raoul Dederen, "The Church," in Handbook of Seventh-day Adventist Theology (Hagerstown, MD: Review and Herald, 2001), 549.

${ }^{71}$ Ibid. 
showed concern and took action on behalf of the needy and suffering. ${ }^{72}$

The proclamation of the three angels' message, one threefold message, is the proclamation of the eternal gospel to every nation, tribe, language, and people before the second coming of Christ as a call to exclusive worship and submission to the will of God. Because faithful believers from Christian and non-Christian religions will find themselves in a common experience of marginalization and persecution during the last days (Rev 12:17), part of the three angels' messages is God's call to His people around the world to come out of Babylon (Rev 18:4) and an invitation to gather together (Rev 14:6) ${ }^{73}$ The first angel has an appeal for people to respond to God's sacrifice through obedience and worship. The second angel warns about a counterfeit system that has been accepted by many. And the third angel addresses those who have joined the opposition to God and explains the consequences of their decision.

The purpose of this threefold message goes beyond proclamation to a preparation of the inhabitants of the earth for the second coming of Christ. ${ }^{74}$ This is applicable to God's remnant people as well as those who receive the three angels' messages. On the one hand, Adventists "acknowledge the imperfections of the remnant and trust in God's power to refine them as they fulfill their mission. This remnant is not exclusive in nature

\footnotetext{
${ }^{72}$ Dederen, "The Church," 550.

${ }^{73}$ Rodriguez, “Concluding Essay,” 212, 225.

${ }^{74}$ Hans K. LaRondelle, "The Remnant and the Three Angels' Messages," in Handbook of Seventhday Adventist Theology, ed. Raoul Dederen (Hagerstown, MD: Review and Herald, 2001), 875-878.
} 
but open to all. It is fundamentally controlled by a sense of mission." "75 "They realize that it is only through God's grace that they can accomplish their momentous task." ${ }^{, 76}$ On the other hand, Adventists have "the profound conviction that not only must the world now be warned concerning the imminence of earth's transcendent event - the second coming of Christ—but a people must be prepared."77

As people accept the eternal gospel and commit to Jesus, the goal is to grow in Christ and live a new life in anticipation of His coming. Three aspects characterize this new life. First, this is a life of the Spirit because it is the result of the regenerating power of the Holy Spirit. Second, it is a life of love and unity because it represents the reconciliation both to God and to fellow human beings. "The entire redemptive mission of Jesus and the power of His gospel cry out for vindication in love and a unity that must bind [together] the members of the redeemed community," which means that "barriers of race, national origin, gender, caste, color, and other divisive factors stand abolished in the life of the person who has experienced the new creation, a new humanity"78

True neighborly love penetrates the color of skin and confronts the humanness of the person; it refuses to take shelter under caste but contributes to the enrichment of the soul; it rescues the dignity of a person from the prejudices of dehumanization; it delivers human dignity from the philosophic holocaust of thing-ism. In effect, true love sees in each face the image of God-potential, latent, or real. ${ }^{79}$

\footnotetext{
${ }^{75}$ Rodriguez, "Concluding Essay," 216. "Faith in the second coming of Jesus affects our value system, creating a motivation for witnessing and evangelization. Of necessity it also presupposes a spiritual preparation.” Lehmann, “The Second Coming of Jesus,” 912.

${ }^{76}$ Ministerial Association of Seventh-day Adventists, Seventh-day Adventists Believe, 197.

${ }^{77}$ Knight, Seventh-day Adventists Answer Questions on Doctrine, 161.

${ }^{78}$ Ministerial Association of Seventh-day Adventists, Seventh-day Adventists Believe, 157.

${ }^{79}$ Ibid., $157-158$.
} 
Third, the preparation for Christ's coming involves developing a life of worship, witness, and hope. Spiritual development happens within the community of the redeemed and as a witness to the community. Christian growth is related to growth in service and toward witness. This is the result of living in anticipation of the final establishment of God's kingdom. Other hallmarks of growing in Christ are a life of study, a life of prayer, a life of spiritual warfare, and a life of fruit bearing. ${ }^{80}$

\section{Toward a Model of Seventh-day Adventist Movement Ethos}

After considering the unique identity, beliefs, understanding about mission of the Adventist movement, it is essential to work toward a model of Seventh-day Adventist movement ethos. That model will include the core (minimal) elements necessary to develop a movement that would reflect the character of Adventism.

That development will be conducted by taking Alan Hirsch's model as a base, reworking the understanding of each element according to unique Adventist beliefs, and taking into consideration elements of continuity and discontinuity. The importance of considering a movement's beliefs in the development of an ethos model is underlined by the understanding that cognitive themes interact with affective and evaluative themes as part of a group's worldview. Nonetheless, the final result of this exercise is a move toward a model of Adventist movement ethos, not beliefs. The character of the early Adventist movement is also important in this discussion since, as previously reviewed, according to the life cycle of movements, the initial phase is characterized by vitality and dynamism. Finally, it is important to include the conclusions of the study of the character

\footnotetext{
${ }^{80}$ Ministerial Association of Seventh-day Adventists, Seventh-day Adventists Believe, 158-161.
} 
of Christianity and its expressions, as introduced in the first chapter. The presupposition that the Adventist movement intends to be an expression of Christianity, especially due to its emphasis on restoring biblical truth, will guide this process.

In the same way the elements are interrelated in Hirsch's model, Adventist distinctive beliefs are interconnected and have multiple implications for all the elements of the model. The most important one, however, is the fact that all of them are universal. ${ }^{81}$ The following description of the elements will seek to demonstrate those implications.

To this central element all others are connected. Christ's role in the plan of salvation through His ministry and mission cannot be underestimated. As part of His mission, He initiated a new phase in God's missionary plan by starting a movement through the training of the twelve disciples, giving them a specific commission, eliminating the ethnic primacy of the Israelites as missionaries, and restating the worldwide scope of God's mission. During the last days it is key to understand that Jesus, who is Savior and Lord, is also a priest in heaven, ministering on behalf of humanity. This should foster an even more genuine relationship with Christ and lead to obedience of His will. His ministry today will give assurance of salvation to those who have accepted Him and warn others of the importance of taking that same step. The understanding that the Lord of time and space is "working in all things to accomplish the divine purpose"

\footnotetext{
${ }^{81}$ Schantz, "The Development of Seventh-day Adventist Missionary Thought," 281-309. For an analysis of the importance of historical events and issues to the development of SDA missionary theory, see part II of Schantz.
} 
should also give bold confidence to join God in His mission. ${ }^{82}$

The great controversy between God and Satan has been the frame of reference for the development of Adventist theology and mission. Mission then has implications in other dimensions besides the natural world since the whole universe is engaged in some way in this scenario of a battle between God and Satan. Among these repercussions is the fact that "the church's witnessing to the heavenly beings is so formidable that they will eventually see in it a full display of God's love." ${ }^{83}$ Hirsch's apostolic influence and fertile environment, for example, should be viewed not simply as a matter of human development and empowerment, but also in terms of Satan's efforts to stop God's mission. The development of inspirational and moral leadership within the context of missionary movements becomes a clear spiritual challenge above all else in which both God, through the Holy Spirit, is bestowing His gifts on His people and Satan is looking for ways to detract them from fully developing those and offering counterfeit demonstrations to confuse people. Therefore, the Adventist movement should develop an apostolic environment that acknowledges the spiritual nature of its context.

The belief in an imminent coming of Jesus has given a sense of urgency to Adventist mission. It should also shape the missional-incarnational impulse of Adventist expressions. The sending and the identification aspects of God's commission take on a special meaning in the context of the last days due to the nature of the spiritual attacks

\footnotetext{
${ }^{82}$ William G. Johnsson, “Adventist Mission Today: A Personal Reflection,” in Message, Mission, and Unity of the Church, ed. Ángel Manuel Rodríguez (Silver Spring, MD: Biblical Research Institute, 2013), 448.

${ }^{83}$ Ángel Manuel Rodriguez, "Oneness on the Church in Message and Mission: Its Ground," in Message, Mission, and Unity of the Church (Silver Spring, MD: Biblical Research Institute, 2013), 256.
} 
and challenges, as well as the urgency of mission driven by living in a state of continual expectancy, watchfulness, and readiness. Thus, the Adventist missional-incarnational impulse happens within an essentially eschatological context.

That context also influences the understanding about communitas in Adventist expressions. A life of continual expectancy in the context of the great controversy should result in hope, love, humility, and holiness. Believers should be motivated to obey God's commandments and develop the values of the Kingdom of God by fostering a sense of love, justice, goodness, beauty, and truth in their community. Adventist expressions should emphasize the importance of the experience of the Sabbath in this context as a special time of fellowship and companionship with God. The Sabbath is an agent of rest, of worship, and of relationships, given with no regards to race, gender, and social status in order to be a cure, a blessing, and a constant reminder of who God is — an important element of holistic development. ${ }^{84}$ Thus, Adventists should keep the future and the present realities in tension, making the experience on earth a foretaste of the heavenly one. ${ }^{85}$ That vigorous transformative vision of living in a restored world in the near future should bring that element of liminality to their experience - something that can only be developed in their common experience. The biblical metaphor of the family is especially relevant for this element that is based on an understanding of God's covenant with His people.

The body of Christ, another biblical metaphor, helps to understand that Christian

\footnotetext{
${ }^{84}$ Wagner Kuhn, Christian Relief and Development: Biblical, Historical, and Contemporary Perspectives of the Holistic Gospel (Engenheiro Coelho, SP, Brazil: UNASPRESS, 2005), 15.

${ }^{85}$ Bull and Lockhart, Seeking a Sanctuary, 162, 180-181.
} 
expressions should be organized—organically structured by the Holy Spirit. The recovery of the awareness of the Holy Spirit's empowerment through spiritual gifts is necessary to enable harmony, edification, and the growth of the church. Adventist expressions should be structured by organic systems, taking into consideration the headship of Christ and the bestowing of spiritual gifts. Spiritual gifts emphasize a common ministry, in which clergy and laity work together in decentralized, spread out, and multiplied ways. In such cases, a simple, flexible, and reproducible denominational structure ${ }^{86}$ helps foster unity and, above all, the mission of the church in an organic, spontaneous, and hyperbolic way. ${ }^{87}$ This is an antidote to overinstitutionalism, typical of older movements. The Adventist movement has especially benefitted from the spiritual gift of prophecy, a characteristic of God's last day people, to guide its development and mission. ${ }^{88}$ The classic Ellen White quotation reminds one that "the church is God's appointed agency for the salvation of

\footnotetext{
${ }^{86}$ For a discussion on flexibility of structural form, see Oliver, "Principles for Reorganization of the Seventh-day Adventist Administrative Structure, 1888-1903, 326-332.

${ }^{87}$ Bruce Bauer has suggested a model, supported by the Antioch Church case and others, that includes congregational and mission structures that relate to each other in three ways: (1) they are semiautonomous in decision making, (2) they a share a common purpose and objective, and (3) they have an agreed upon common reference point. In 1983, after a historical analysis of mission structures, Bauer recommended the Seventh-day Adventist Church establish a semi-autonomous mission board with power to promote, raise funds, survey the world field, and pick and appoint a mission board team. Bruce L. Bauer, "Congregational and Mission Structures and How the Seventh-day Adventist Church Has Related to Them" (DMiss diss., Fuller Theological Seminary, 1983).

${ }^{88}$ As Timm points out, Ellen White's missiological contribution to the Adventist church was based on the convergence of three basic concepts: (1) God's saving grace is universally accessible to all sincere Christian and non-Christians who live according to the light available to them; (2) all children of God are responsible for sharing the light they receive with others; and (3) the SDA Church is God's end-time remnant church with the prophetic mission of restoring and preaching all biblical truths to the entire world. Alberto R. Timm, "The Role of Ellen G. White in the Life of the Adventist Church," in Message, Mission, and Unity of the Church, ed. Ángel Manuel Rodríguez (Silver Spring, MD: Biblical Research Institute, 2013), 354-355.
} 
men. It was organized for service, and its mission is to carry the gospel to the world." 89

Being an expression of God's people in the end times means to develop a way of living, both individually and collectively, that includes engaging in God's holistic mission. The remnant is not only the missiological result but also the missionary means. Adventist eschatological understanding "do not entail a rupture with, but rather a reorientation of, everyday life." 90 Adventist expressions define their mission in terms of (1) making disciples of all nations, (2) instructing believers, (3) caring for the needy and suffering, and (4) glorifying God. Mission, therefore, happens in the context of the purpose of the three angels' messages that goes beyond proclamation and includes the preparation of the inhabitants of the earth for the second coming of Christ. This preparation involves developing a life of Spirit, love and unity, worship, witness, and hope. It involves a holistic development that is inclusive and integrative and addressed the person in his or her wholesomeness, both in word and deed, as a work of redemption and transformation. ${ }^{91}$ Thus, disciple making in the context of the three angels' messages means leading people toward God as they receive the eternal gospel with the objective of developing a worshipful way of living and a character according to the Lord's, and sharing with others about God's love in preparation for God's final encounter.

${ }^{89}$ Ellen G. White, The Acts of the Apostles (Washington, DC: Pacific Press, 1911), 9.

${ }^{90}$ Marisa Louise Peeters, "Living with the End of Times: An Analysis of American Seventh-day Adventism" (MA thesis, University of California, San Diego, 2009), vi.

${ }^{91}$ Kuhn, Christian Relief and Development, 135, 144. 
The waiting time, for Adventists, is a time for witnessing. "Global mission and evangelism are essential elements of the SDA ethos."92 As the official statement concerning Adventist mission declares, "Mission is woven into [the SDA church's] identity; mission defines who [Adventists] are and why [Adventists] exist." ${ }^{93}$ This missionary identity at the center of their self-understanding will move people toward unentered areas and unreached people groups, thus keeping the community open, adaptable, and alive. The description of the heavenly great multitude that no one could count in Rev 7:9 implies the universality of the saved and that they all do not come from the traditional Christian strongholds, but also from areas that are today predominantly dominated by the world's religions. ${ }^{94}$

Therefore, a model for Seventh-day Adventist movement ethos would include the following six elements: confession of Jesus as Savior, Lord, and Priest; a missionalincarnational impulse of the soon coming of Jesus; an apostolic movement as part of the Great Controversy; communitas as a reflection of the will of God for relationships as described in God's commandments; organic systems according to spiritual gifts; and disciple making in preparation for eternity (see figure 4).

These six elements seem to be part of the essence of the ethos of any Seventh-day Adventist movement. The same way all elements of Hirsch's model of ethos of missionary movements are interrelated, these elements are part of a whole, which could

\footnotetext{
${ }^{92}$ World Council of Churches, "Seventh-day Adventist Church," accessed September 5, 2014, http://www.oikoumene.org/en church-families/Seventh-day-adventist-church.

${ }^{93}$ General Conference of Seventh-day Adventists, "Roadmap for Mission," in Statements, Guidelines \& Other Documents, ed. Communication Department of the General Conference (Hagerstown, MD: Review and Herald, 2010), 253.

${ }^{94}$ Johnsson, “Adventist Mission Today,” 449.
} 
include other elements for specific emphasis. The application of the Adventist beliefs has broadened and deepened the understanding of the elements of Hirsch's model and, at the same time, grounded the definitions in the Bible. One of these implications is the fact that Adventist mission happens in the end times in preparation for the second coming of

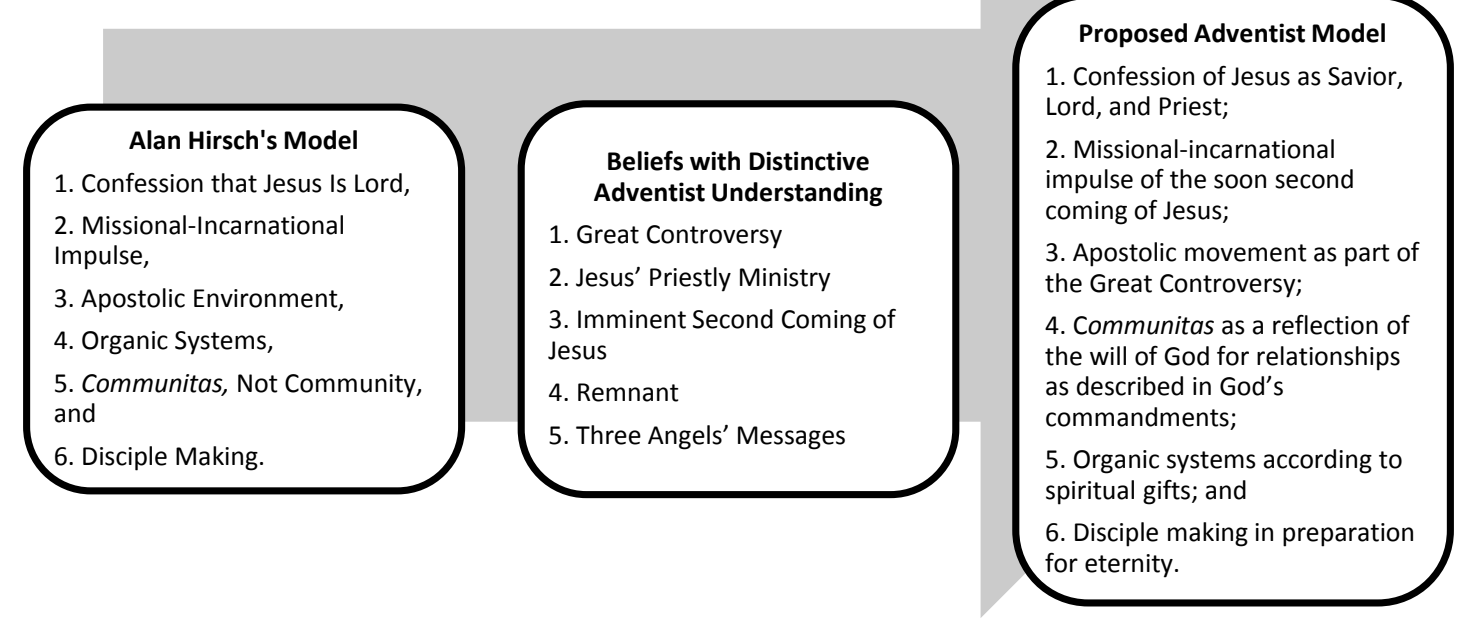

Figure 4. Toward a model of Seventh-day Adventist missionary movement ethos

Christ and God's final judgment and, therefore, the ethos characteristics of an

Adventist missionary movement should reflect that specific context. The prophetic

context permeates Adventist mission as demonstrated early on.

That prophetic understanding of their mission, integrated with their doctrines within the framework of the three angels' messages, provided the Sabbatarians with the motive power to sacrifice in order to spread their message far and wide. That same dynamic operated in Millerism. Unfortunately for Seventh-day Adventism, that very vision appears to be in jeopardy in the twenty-first century. ${ }^{95}$

${ }^{95}$ Knight, The Apocalyptic Vision and the Neutering of Adventism, 287. 
As William Johnsson points out, Adventists, in the last days, are to be "a creative remnant highlighting the character of God and calling all peoples of the world to put God first." While Adventists should be humbled by this commission, they should not doubt the ultimate success of God's mission. ${ }^{96}$

Movements go through different stages as time progresses, however by keeping a movement ethos with these aspects, the vitality and relevance will remain. These elements will ensure that movements are expressions of their time and place, thus applying the gospel in specific contexts as well as responding to people's existential questions and needs. "Adventism became strong by proclaiming that it had a prophetic message for our time. And it is that message repackaged for the twenty-first century that will give Adventism strength both in the present and in the future." $" 97$ Those elements will ensure that the true and authentic character of Adventism is recovered and preserved, thus relying on the power of God's gospel, the centrality of Jesus, and the ministry of the Holy Spirit. The desired engagement of believers in God's mission will also be fostered and the consequencewill be an impact on the fulfillment of the will of God.

Besides the use of this model to guide the development of new expressions of Adventism through, for example, church planting movements, social media movements, insider movements, literature distribution movements, another application is envisioned: the assessment of current expressions of Adventism. An obvious observation is that this model is based on the ideal proposed by Adventist beliefs, which certainly is not the reality in any Adventist expression, but should guide every part of the Adventist

\footnotetext{
${ }^{96}$ Johnsson, “Adventist Mission Today,” 449.

${ }^{97}$ Knight, The Apocalyptic Vision and the Neutering of Adventism, 19.
} 
movement. Instead of a weakness, this should be a strength of this instrument as it is used to analyze movements. This model is different from most common measuring processes that look exclusively at results, often only numeric data, while this model proposes a closer look at the other side of the process: the beginning.

This model could be especially useful to analyze mission strategies. While, the more traditional approaches have often generated a faulty mentality that "the ends justify the means" by insisting on the importance of fostering Christian expressions in general, and in particular developing strategies based on biblical principles, a complementary understanding should be reached that "the beginnings justify the means." This look at revelation in the Bible, the ministry of Jesus, and the experience of the Early Church should bring a balance and direction to missionary movements.

The essential analysis of church has been more focused on measuring numbersbodies, budget, and buildings - in order to indicate success than seeking faithfulness to the essence, nature, or character of Christianity and its effects in transforming people. This seems to stem from confusion with the definition of church as a destination instead of an agency. ${ }^{98}$ Emphasizing the principles helps establish solid faithful biblical foundations that will keep a movement ethos throughout the development of that expression of Christianity; allow the Holy Spirit to guide the missionary efforts of God's people; foster contextualized expressions of Christianity; mobilize and involve church members according to God's call and guidance; and help Christianity impact communities through the presence of the powerful and transforming gospel.

\footnotetext{
${ }^{98}$ Ed Stetzer and Thom S. Rainer, Transformational Church: Creating a New Scorecard for Congregations (Nashville, TN: B \& H Publishing, 2010), 26.
} 
The Adventist prophetic mission should compel its members to a higher degree of intentionality and faithfulness, since "Christ explicitly teaches that those waiting for His return must put their emphasis on being faithful servants." ${ }^{" 99}$ By carefully studying expressions of the Adventist movement through instruments like this the church should be able to align itself with the plan of God and more faithfully fulfill His mission.

In a special sense Seventh-day Adventists have been set in the world as watchmen and to them has been entrusted the last warning for a perishing world. On them is shining wonderful light from the word of God. They have been given a work of the most solemn import - the proclamation of the first, second, and third angel's messages. There is no other work of so great importance. ${ }^{100}$

The next two chapters will apply this model of Christian movement ethos to the Adventist movement in Brazil. The use of such an instrument to analyze mission methods employed by the Adventist Church in Brazil will help identify how those strategies have followed missiological principles and fostered a movement ethos. 19.

${ }^{99}$ Knight, The Apocalyptic Vision and the Neutering of Adventism, 101.

${ }^{100}$ Ellen G. White, Testimonies for the Church, vol. 9 (Mountain View, CA: Pacific Press, 1948), 
PART III. THE ETHOS OF THE ADVENTIST MOVEMENT IN BRAZIL: A REVIEW OF MISSION METHODS 


\section{CHAPTER 7}

\section{THE ETHOS OF THE SEVENTH-DAY ADVENTIST MOVEMENT}

IN BRAZIL BETWEEN 1893 AND 1942

In a little over 100 years, the Adventist Church in Brazil has grown to a membership of 1,447,470 (December 2013), becoming the country with the second highest total number of Adventists in the world. ${ }^{1}$ The Adventist message that was first shared in the small state of Santa Catarina, where a package of Die Stimme der Wahrheit (The Voice of Truth) magazines was delivered sometime between 1879 and 1880, spread to the whole nation. The first ordained Adventist minister, Frank Westphal, arrived in $1895^{2}$ and began "the pioneering phase of the Adventist movement in South America."3 The Adventist Church's development and growth in more than one dimension has been the result of many different factors, methods, and experiences.

Adventists in Brazil continue their desire to be faithful to God's mission in the twenty-first century by employing different mission methods. A vital step in that process is a panoramic review of mission methods based on the Adventist movement ethos

${ }^{1}$ General Conference of Seventh-day Adventists, Annual Statistical Report (2013), 80.

${ }^{2}$ Streithorst, “O Início da Nossa Obra,” 29.

${ }^{3}$ Greenleaf, A Land of Hope, 24. This work and The Seventh-day Adventist Church in Latin America and the Caribbean are the most comprehensive works on the history of the Adventist Church in South America, describing the different evangelistic initiatives of the church. 
model. This section will consider mission methods used by the Adventist Church in Brazil from its beginning around 1893 until $2007^{4}$ in order to learn lessons for the present and future.

Since the beginning of the movement in Brazil, Adventists sought ways to introduce people to the Adventist message, establish churches, and mobilize members to engage in that mission of evangelization. Adventist mission in Brazil was influenced by the background and mindset of missionaries as well as contextual developments in Brazil involving politics, economy, and demographics, among others. Despite the country's diversity and continental dimensions, at a panoramic level, one is able to consider the "astonishing sociological phenomenon of Brazilian unity," especially in terms of values. ${ }^{5}$ That same unity in diversity is observable and fostered within the church by the high power distance aspect of the culture. ${ }^{6}$

\footnotetext{
${ }^{4}$ Alberto R. Timm, "Primórdios do Adventismo no Brasil,” Revista Adventista, January, 2005, 14. In 2007, the current administration was elected to the South American Division. The subjectivity of the analysis of an ongoing project suggests that it would not be productive to try to review mission methods currently in place. This delimitation does not affect the perception that the Adventist movement ethos model is valid and applicable to the present in Brazil.

${ }^{5}$ Gilberto Freire, cited in Marshall C. Eakin, Brazil: The Once and Future Country, 1st ed. (New York: St. Martin's Press, 1997), 67; Marcus Faro de Castro and Gilberto Marcos Antonio Rodrigues, "Brazil," in Diversity and Unity in Federal Countries, A Global Dialogue on Federalism, ed. Luis Moreno and César Colino (Canada: McGill-Queen's University Press, 2010); Eugene A. Nida, Understanding Latin Americans: With Special Reference to Religious Values and Movements (Pasadena, CA: William Carey Library, 1974).

${ }^{6}$ This is the cultural dimension that determines a society's view on power and status and how people should relate to each other. Power distance is the term used to define the differences members of society follow in that regard. Geert H. Hofstede, Culture's Consequences: Comparing Values, Behaviors, Institutions, and Organizations across Nations, 2nd ed. (Thousand Oaks, CA: Sage Publications, 2001), 8384. "In organizations in high power distance cultures, you find a greater centralization of power, more recognition and use of rank and status, and adherence to established lines of authority." Larry A. Samovar and others, Communication between Cultures, 8th ed. (Boston, MA: Cengage Learning, 2013), 189.
} 
This chapter reviews five major mission methods adapted from Timm's suggestion in his article "Building a Growing Church: The South American Experience." According to him, from a historic viewpoint, the Adventist movement introduced these methods one at a time as "ongoing methodological experiments" that continue to be used. ${ }^{7}$ The five mission methods are literature evangelism, public evangelism, radio and television evangelism, metropolitan evangelism, and "integrated evangelism.".

The objective of this section is not a comprehensive description of the history of the Adventist movement in Brazil, nor a detailed account of every local effort throughout the country related to those major mission methods. For each mission method a brief description of the social and the Adventist denomination contexts in which they developed will be given along with a review of the six elements that make up the Adventist movement ethos model suggested in the previous chapter.

\section{Literature Evangelism (1893)}

The organic nature of the Gospel acting in the lives of the children of God who are transformed by His revelation becomes clear in the experience of the first seeds of Adventism in Brazil. Through lay members and literature the message was planted in the

\footnotetext{
${ }^{7}$ Timm, "Building a Growing Church.” Timm suggests six methods: literature evangelism, public evangelism, radio and TV evangelism, preaching to larger audiences, small groups, and "integrated evangelism." A major difference is that Timm was analyzing the Adventist experience in South America and was not restricted to Brazil; however, this research takes into consideration only the experience in Brazil, treats preaching to larger audiences as part of the "metropolitan evangelism" initiative and small groups as part of "integrated evangelism."

8"Integrated evangelism" was a South American Division initiative aimed at combining the missionary efforts of the different denominational departments, institutions, and people. It promoted a variety of disciple-making strategies. This mission method will be described in more detail later in this chapter.
} 
new territory even before the organization officially approached that part of the American continent.

\section{Contextual Dynamics in Brazil: The First Republic}

Since the "discovery" of Brazil in 1500, it had been a Portuguese colony. The long process of independence finally came to a conclusion in 1822 in a relatively nonviolent way. The next 67 years witnessed a Portuguese monarchy that transitioned the country into a republic in 1889 . During that time, Brazilian society was dominated by landowning aristocrats and labor producing slaves. Emperor Dom Pedro I (1822-1831), a regency (1831-1840), and emperor Dom Pedro II (1840-1889) led the country through separatist challenges to the end of two institutions - monarchy and slavery — and left a large mixed-blood population and a strong desire for development. This was a much more inviting place in many ways. ${ }^{9}$

At the turn of the 20th century, Brazil was a welcoming place for Protestant missions. At least three major reasons contributed to that condition. First, although a Portuguese translation of the Bible had been available, in 1879 the New Testament was published in Rio de Janeiro, Brazil, for the first time by the Society of Moral and Religious Literature. ${ }^{10}$ Second, non-Catholics officially enjoyed new freedom. After the proclamation of the republic in 1889, the government decreed (Decree 119A) the liberty of worship and abolished Catholicism as the official state religion. ${ }^{11}$ The first constitution

${ }^{9}$ Skidmore and Smith, Modern Latin America, 137-145. The economy relied on agriculture, especially sugar, and 4 million people, half of them African slaves (by birth or descent).

${ }^{10}$ Ruy Carlos de Camargo Vieira, Vida e Obra de Guilherme Stein Jr: Raízes da Igreja Adventista do Sétimo Dia no Brasil (Tatuí, SP, Brazil: Casa Publicadora Brasileira, 1995), 87.

${ }^{11}$ Ibid., 84. 
(1891) followed in the same direction consolidating the changes and making reference to civil marriage, secularization of cemeteries, and the laiticity of public teaching. Third, the window of opportunity for immigration was more open than before, especially for farmers with families, due to the friendly attitude of the government and to the abolition of slavery.

\section{Contextual Dynamics in the Church: Entering Brazil}

Seventh-day Adventists had been following the new developments and were starting to grasp the opportunities that lay ahead of them, as one can see in one of their publications of that time.

All of South America except a small part of the interior is also under the Catholic rule. At Rio de Janeiro, the capital of Brazil, the harbor scenery is grand and picturesque. The finest woods grow in the interior, but in these the climate is very unhealthful, and so very little Protestant work has been done in Brazil. ${ }^{12}$

As Floyd Greenleaf, Adventist historian, has pointed out, the actual starting point of Adventism in Latin America depends on how one defines it. As it will become clear later on, ordained ministers were preceded by book salesmen (colporteurs), but those were also preceded by the Adventist message. The proclamation of the Second Coming of Christ, in Latin America, was already being done by others. ${ }^{13}$ Moreover, there were Sabbath keepers in Brazil before the arrival of Adventist missionaries. ${ }^{14}$ $1893,164$.

${ }^{12}$ L. C. Chadwick, "Travels in South America," General Conference Daily Bulletin ,February 6 ,

${ }^{13}$ The second coming of Jesus had been preached in Latin America by people like Manuel Lacunza, Jose Maria Gutierrez de Rozas, Francisco Ramos Mexia, and Manuel Belgrano. Greenleaf, The Seventh-day Adventist Church in Latin America and the Caribbean, 1:9, 10.

\footnotetext{
${ }^{14}$ The Seventh-day Adventist Encyclopedia, 2nd rev. ed. (Hagerstown, MD: Review \& Herald, 1996), s.v. "Brazil."
} 
The first Seventh-day Adventists to arrive in Brazil were German-Russian families, baptized in Europe, who immigrated in the 1880s to Rio Cunha, near Rio dos Cedros, Santa Catarina, Brazil. ${ }^{15}$ As Timm makes reference, Adventist magazines in German, Die Stimme der Wahrheit (The Voice of Truth), printed in Battle Creek, Michigan, had already been delivered to the harbor city of Itajaí in the same Brazilian state sometime between 1879 and $1880 .^{16}$

Although literature evangelists went to South America in the 1890s, a report in The Present Truth, suggests 1893 as the official beginning of the Adventist Church in many Latin American countries, including Brazil: "In many respects the past year has been the most prosperous in our history. This is especially true of our educational, publishing and medical work. Missions have been established in Mexico, Honduras, British Guiana, Argentine, Brazil and Jamaica." 17

Two years later, O. A. Olsen, General Conference president at the time, attests to the initial developments of the work in South America in ways that apparently would set the pace for the evangelization in that continent.

\footnotetext{
${ }^{15}$ Victor Vicenzi, História de Rio Dos Cedros (Blumenau, SC, Brazil: Fundação Casa Dr. Blumenau, 1975), 124, 125.

${ }^{16}$ Timm, "Building a Growing Church," "The reason for their arrival centers in the story of a young German named Burchard, who, having violated a local law, fled Brazil as a stowaway on a German ship. Discovered en route to Europe, he was obliged to work out his passage. While on board he conversed with two SDA missionaries, who questioned him regarding religious interest and activities among the people of his community. They learned that the Lutherans were active in evangelistic work among German immigrants, especially in the state of Santa Catarina. Obtaining from Burchard the address of his stepfather, Carlos Dreefke, who lived in Brusque, Santa Catarina, they decided to send him SDA publications." The Seventh-day Adventist Encyclopedia.
} 1894.

${ }^{17}$ E. J. Waggoner, The Present Truth, January 24, 1895, 54. The report would have been written in 
Since our last meeting the work in South America has been more firmly established, and beginnings have been made in various localities.... We have been surprised at the rapid development of the work in South America. For many years the Lord has been preparing the way, and hearts are ready for the reception of the truth. ${ }^{18}$

\section{Mission Method}

In spite of the suggestions to use schools as the primary evangelistic agencies, the primary method of evangelization employed by the church in the beginning was literature evangelism, which had already been happening on a smaller scale without the knowledge of the church, as mentioned earlier. As Greenleaf points out, the first attempt to establish a literature distribution program in South America started when three colporteurs arrived in Montevideo, Uruguay, on December 10, $1891 .{ }^{19}$ Two years after the arrival of the first literature evangelists in South America, A. B. Stauffer visited the German settlements in southern Brazil. ${ }^{20}$

A report at the end of 1895 was optimisic about the work of colporteurs in Brazil. ${ }^{21}$ It pointed out the wide influence exerted by Adventist publications, several

108.

${ }^{18}$ O. A. Olsen, “The President's Address,” General Conference Daily Bulletin, February 22, 1897,

${ }^{19}$ Greenleaf, The Seventh-day Adventist Church in Latin America and the Caribbean, 1:15.

${ }^{20}$ A. B. Stauffer, "Report from Argentina and Uruguay," Review and Herald, June 13, 1893, 6. While in Uruguay, Stauffer became acquainted with two colonies of Waldensians who raised wheat and corn. A. B. Stauffer, "Report from Brazil," Review and Herald, February 20, 1894, 4. The report was written on December 28, 1893.

In 1905, John Loughborough, pioneer of the Adventist church, confirmed these early developments in his report. J. N. Loughborough, The Great Second Advent Movement: Its Rise and Progress (Washington, DC: Review and Herald, 1905), 434. The initial destination of W. H. Thurston, her sister, Mary Westphal, and her husband F. H. Westphal, in 1894, was Argentina. Although Thurston was not ordained, his target was Portuguese-speaking Brazil. Initially he was a self-supporting worker and a few months later he received missionary credentials. Greenleaf, The Seventh-day Adventist Church in Latin America and the Caribbean, 1:17. Stauffer and Thurston shared the majority of the book work in Brazil during the initial years.

21،In August 1895 two brothers, Alberto J. and J. Frederico Berger, arrived from the United States and began colporteur work in the colony of Santa Leopoldina, Espírito Santo state, and later in the state of Santa Catarina. In two and a half months they sold \$400 worth of SDA publications, a sizable amount at 
companies founded and ready for church organization, and a deep and growing interest by many people. In 1896 in Brazil and Argentina book sales amounted to ten thousand dollars and there were one hundred observing the Sabbath. ${ }^{22}$ But it was not until fifteen years later that "the first spurt occurred in literature evangelism in Brazil." Between 1910 and 1912, in the East Brazil Mission, nine canvassers grew to 27 and other colporteurs arrived from the United States, including R. M. Carter, the new leader of sales work in Brazil. $^{23}$

The beginnings of Adventism in Brazil, introduced by literature evangelism, witnessed many relevant missiological dynamics. It is essential, for the purpose of capturing the movement ethos then, to identify the six elements of an ideal Adventist movement, as developed in the previous chapter.

\section{Jesus: Lord, Savior, and Priest}

The Adventist distinctive message was present from the very beginning of the Adventist movement in Brazil. This element of the Adventist movement ethos model would be more thoroughly demonstrated in a study of the cognitive themes within the worldview of Adventists during that time, which is not the focus of this study. However, clear indications of the eschatological emphasis of the movement are found in the titles of

that time. Later they worked in Mucuri, Minas Gerais, and in southern Bahia state, being pioneers in both regions. In 1897 they began their work in Rio Grande do Sul." The Seventh-day Adventist Encyclopedia.

${ }^{22}$ Loughborough, The Great Second Advent Movement, 435.

${ }^{23}$ Greenleaf, The Seventh-day Adventist Church in Latin America and the Caribbean, 1:111. Beginning in 1908, a few events helped improve the distribution of literature in Brazil. John Lipke did training sessions for new colporteurs in 1908. In January 1909, Brazilians dedicated their new publishing house in Santo André, and only days later they gathered again in Itapetininga, 100 miles away, to lay plans for more colporteur institutes. Ibid., 1:110. 
the literature being distributed. ${ }^{24}$ "They all sounded the tones of the urgency of the gospel and the announcement of the Second Advent." 25 These are some indicators that the Adventist message was a strong influence in the shaping of the worldview of the Adventist movement in Brazil and, consequently, of its ethos.

\section{Missional-Incarnational Impulse of the Coming of Jesus}

The expansion of the Adventist movement and its beginning in Brazil was motivated by a missional-incarnational impulse, the second element of the Adventist movement ethos model. The missionary motivation was severely tested by the many difficulties and hardships of the Brazilian environment. These included sickness and death, an unstable economy, politics, extreme weather including tropical heat and heavy rains, long distances to travel, and rudimentary means of transportation and communication. Missionaries faced yellow fever, measles, scarlet fever, floods, landslides, sleeping on the ground in wet clothes, and being away from home and family for days while on long journeys. Since traveling was a central part of their efforts to spread the message and, at the same time, keep the groups united, their exposure to those hazardous elements was a given. ${ }^{26}$ Stauffer pointed out, however, that the dangers of war

\footnotetext{
${ }^{24}$ For example, the very first periodical delivered in Santa Catarina was called Stimme der Wahrheit (Voice of Truth). One of the first German immigrants to accept the Adventist message in the same state was Guilherme Belz who had been influenced by the book Gedanken über das Buch Daniel (Thoughts on the Book of Daniel) by Uriah Smith. The Adventist message was introduced to Guilherme Stein III, who had been a Methodist, through the book Der Grosse Kampf (The Great Controversy) by Ellen G. White. Other titles of missionary papers followed the same emphasis including words such as lighthouse, sentinel, watchman, herald, and messenger.

${ }^{25}$ Greenleaf, A Land of Hope, 68.

${ }^{26}$ Ibid., 37-40, 138-140. F. W. Spies, "Brazil,” Review and Herald, April 13, 1905, 14-15. John Lipke, "A Trip to a General Meeting in Brazil," Review and Herald, September 28, 1905, 13-14. F. W.
} 
and epidemic diseases were not the greatest perils, but the "the great selfishness and wickedness prevailing everywhere, and an unseen force working in the air, are the things which imperil, not our lives but our souls."27

Hardships sometimes came in the form of opposition to their work. Missionaries were occasionally accused in news stories. ${ }^{28}$ However, none of those challenges were big enough to stop Adventist missionaries from complete dedication to their mission in Brazil and seeking to expand their work into unentered areas.

During the first years of Adventism in Brazil, two major elements influenced their incarnational efforts: the economy and the language. E. W. Snyder, C. A. Nowlen, and A. B. Stauffer noticed, for example, that costs of transportation and postage were low, but the overall economic situation did not help, with inflation in 1880s and a crash in 1890. None of them spoke Spanish and Stauffer was the only one who spoke German. There was only a small community of English-speaking residents and book sales were handled

Spies, "Rio de Janeiro, Brazil," Review and Herald, March 22, 1906, 14-15. John Lipke, "A Trip through Santa Catarina and Parana," Review and Herald, June 2, 1903, 14. W. H. Thurston, "Brazil," Review and Herald, December 15, 1896, 11-12. H. F. Graf, "Brazil," Review and Herald, February 9, 1897, 9. Arthur Fulton, "Argentina," Review and Herald, July 18, 1907, 18. J. W. Westphal, "Elder B. C. Haak," Review and Herald, January 21, 1915, 14. F. W. Spies, "Rio Grande do Sul Conference," Review and Herald, June 4, 1914, 11-12. Emilio Hoelzle, "Conferência do Rio Claro," Revista Mensal, July 1908, 2-3. Waldemar Ehlers, "Conferência Der Santa Catharina-Paraná," Revista Mensal, August, 1909, 3-4. W. H. Thurston, "Brazil," Review and Herald, August 13, 1895, 11. F. W. Spies, "Experiences in Brazil," Review and Herald, October 25, 1898, 10-11. Graf, for example, in 1898, traveled on one of his longest itineraries, which became known as "One Hundred Days on Muleback." Spies, during one four-month period, traveled 600 miles by water, 500 miles by rail, and 1,700 miles by muleback. The Seventh-day Adventist Encyclopedia. Westphal traveled 1,400 miles by mule in 1904. Greenleaf, A Land of Hope, 86.

${ }^{27}$ Stauffer, "Report from Argentina and Uruguay," 6.

${ }^{28}$ Westphal, for example, was mentioned as a possible spy for either the United States or Germany. Internally, a Portuguese translation of D. M. Canright's Seventh-day Adventism Renounced made waves and required intentional work by the missionaries in order to overcome its influence. J. W. Westphal, "Brazil," Review and Herald, October 13, 1904, 12. F. W. Spies, "Brazil-General Meetings," Review and Herald, November 2, 1905, 16. 
by authorized dealers only. ${ }^{29}$ This situation improved shortly after. ${ }^{30}$

In some ways, both issues, the economy and the language, were addressed when, in 1905, John Lipke took a press to Taquari that had survived a fire at the Review and Herald Publishing House in the United States. That was an important step toward producing local literature. It was cheaper to import most of the German literature from Europe, but they had to produce their own publications in Portuguese. ${ }^{31}$

The issue of learning the local language, however, persisted. The first converts were German immigrants who had contact with Adventist books. Most of those families were concentrated in the southern states of Brazil where the climate was similar to their mother country. By the end of 1895, 35 converts had been baptized into the Adventist Church in Brazil. All were of German birth or descent, or were people who spoke

\footnotetext{
${ }^{29}$ Greenleaf, The Seventh-day Adventist Church in Latin America and the Caribbean, 16. Their books were selling for 9-18 dollars, depending on the binding, which was very expensive for regular Argentine workers who earned only two or three dollars a day.

${ }^{30}$ In 1899, Thurston wrote of the urgent need for tracts and magazines in the language of the country. "We have no tract nor paper in the Portuguese tongue, and, in fact, nothing to give the people to read, and they are afraid of the Bible. We are, however, preparing manuscript for the first issue of our Portuguese paper planned long ago. But even when we shall have the matter prepared for the press, we do not know how long we must wait before we can print the first edition, because our funds are low." The Seventh-day Adventist Encyclopedia. By late 1894, R. B. Craig, appointed to head the literature sales work in South America, reported that they were now selling the book Patriarchs and Prophets in Spanish. Stauffer indicated that $80 \%$ of the population of 15 million could not read or write. Stauffer, "Report from Argentina and Uruguay," 6.

${ }^{31}$ W. H. Thurston, "Brazil," Review and Herald, November 21, 1899, 12-13. F. W. Spies, "Brazil Conference," Review and Herald, August 25, 1904, 13. Westphal, "Brazil," 12. John Lipke, "Travels in Behalf of Brazil," Review and Herald, December 22, 1904, 17. A. L. Gregory, "Brazil," Review and Herald, January 4, 1906, 16. Guilherme Stein Jr. translated Steps to Christ and obtained permission to translate Bible Readings for the Home. In 1900, O Arauto da Verdade was first published with Stein as the editor. Greenleaf, The Seventh-day Adventist Church in Latin America and the Caribbean, 1:66.
} 
German. Soon the state of Rio Grande do Sul became a center for evangelism in Brazil. ${ }^{32}$ In 1899 the first Seventh-day Adventist service in Portuguese was held in Spies' home. He seemed to be the most concerned with transitioning to the Brazilian language and took advantage of every opportunity to learn Portuguese. ${ }^{33}$

When Adventist schools began, language was also an issue, since there were very few Adventist who spoke Portuguese in the beginning. Although those schools were beginning to produce church workers, Stauffer insisted on the language issue: "This is not a German, but a Portuguese field, therefore we need to lay plans for more advanced and broader work along this line. . . The best way to do this is by educating native talent."34 Gradually, foreign missionaries found ways to improve their preparation and reach out to Brazilians. Seven years after the organization of the first church in 1902 , among the 860 members of the Adventist Church in the country, 150 were from Portuguese-speaking communities. ${ }^{35}$ When, in 1913, in order to meet personnel deficiencies, 17 missionaries were sent to Brazil, they spent several weeks studying

${ }^{32}$ The Seventh-day Adventist Encyclopedia. Guilherme Stein Jr., the first person of Brazilian birth was baptized in March 1895. Ibid. Stauffer estimated more than 200,000 German descendants in Brazil in 1893. Stauffer, "Report from Argentina and Uruguay," 6.

${ }^{33}$ At this occasion he found himself without an interpreter and for the first time he experienced evangelizing the "natives" in Portuguese. As a result, he commented on the freedom of communication and the desire to work exclusively among Brazilian. Greenleaf, A Land of Hope, 78. F. W. Spies reported: "We had long looked forward to the time when we might begin work among the natives of this large city. Finally the Lord so arranged matters that Brother Wm. Stein, a native brother, and his family moved to this place, and on Saturday evening, October 21, we held the first service in the Portuguese language, in our home." F. W. Spies, "Brazil," Review and Herald, February 20, 1900, 12. Five years later, he continued to emphasize the importance of learning the language in order to reach Brazilians in their heart language Greenleaf, A Land of Hope, 86; Spies, "Brazil," 15.

${ }^{34}$ A. B. Stauffer, "Brazil," Review and Herald, December 3, 1901, 11.

${ }^{35}$ Greenleaf, A Land of Hope, 78; F. W. Spies, “Organization of the Brazil Conference," Review and Herald, October 21, 1902, 17. 
Portuguese in São Paulo before beginning their activities. ${ }^{36}$

\section{Apostolic Environment within the Great Controversy}

Literature evangelism relied on the dynamic leadership of colporteurs such as

R. M. Carter, a young licensed minister who arrived in 1914 and became successful at canvassing and enthusiastic about promoting literature distribution. ${ }^{37}$

However, the most obvious observation of an apostolic environment, an element of the Adventist movement ethos model in the early years of Adventism in Brazil, is the participation and initiative of lay leaders. Although there was a dominant North

American presence in Brazil during the initial years of the evangelization of that "foreign mission field," the limited number of ordained ministers forced local congregations to rely on the leadership of their own people. ${ }^{38}$ While Westphal and the other ministers spent months at a time traveling around the country, Adventist congregations and small companies were often left on their own for months, sometimes one or two years. ${ }^{39}$ It

${ }^{36}$ F. W. Spies, “An Encouraging Event for Brazil," Review and Herald, December 11, 1913, 9; Henry Haefft, "Missionaries on Their Way to Brazil," Review and Herald, February 26, 1914, 11.

${ }^{37}$ R. M. Carter, "Manuel-a Brazilian Colpoteur," Review and Herald, April 12, 1917; N. Z. Town, "The Literature Work in Brazil," Review and Herald, March 23, 1916.

38“'Ordained men were official church leaders to whom the nuclear congregations were responsible; but initially, pastoral visits were few, as ministers traveled widely, months at a stretch ... Sabbath school superintendents, deacons, and congregational elders were handpicked and charged with local leadership during the minsters' absences." Greenleaf, The Seventh-day Adventist Church in Latin America and the Caribbean, 22.

${ }^{39} \mathrm{~A}$ unique circumstance is reported about the members of Santa Leopoldina who had not seen a minister for 15 months and did not even have a local church elder. Despite the lack of support and formal leadership, the congregation had over 23 people awaiting baptism when Spies and Graf visited in 1897, making the membership 46 people. F. W. Spies, "Brazil," Review and Herald, May 25, 1897, 11. 
should be noted that some of the first health and educational institutions were also the result of efforts by lay members. ${ }^{40}$

\section{Community for God}

Itinerant Adventist ministers fostered more than local leadership, they also fostered a strong sense of community for God, an element of the Adventist movement ethos model. Greenleaf points out that "since their earliest days, Adventist minister and administrators who followed them had cultivated a unique solidarity by frequent itineraries to local congregations." The Adventist historian shares a common understanding that "consultation and counsel, repeated often, had helped to unite Adventists in a single movement." It is as if the Adventist identity as a viable denomination was possible only "by welding the scattered groups of communicants into a single entity."41

\section{Spiritual Organic Systems}

Spiritual organic systems, another element of the Adventist movement ethos model, can be identified in the beginning of the missionary work in Brazil even though there was no formal local structure. But that did not mean missionaries were disorganized. On the contrary, the first years of the work in Latin America, and specifically in Brazil, were characterized by an interesting synergy between colporteurs and ordained ministers. Colporteurs were self-supporting workers who did not pose a financial risk for the church, and were committed to the evangelization of the local

\footnotetext{
${ }^{40}$ The first Adventist school, for example, was started in 1896 by dedicated church members. The Seventh-day Adventist Encyclopedia.

${ }^{41}$ Greenleaf, The Seventh-day Adventist Church in Latin America and the Caribbean, 31, 32.
} 
people. Colporteuring depended heavily on mobility, which prevented the salesmen from settling, establishing headquarters or permanently connecting with a congregation. In contrast, ministers as salaried workers could devote all their time to pastoral and organizational tasks. Colporteurs acted as path finders and ordained ministers followed them in order to study wih the new interests. ${ }^{42}$

In 1894, Westphal became the first ordained minister assigned to oversee the Adventist work in Argentina, Uruguay, and Brazil. A year later, Graf went to work in Brazil and, in 1896, Spies was transferred from Germany to Brazil. In February 1895, Frank Westphal spent five months in Brazil in company with Stauffer, Thurston, and Graf in an organizational campaign. During that time Westphal met with German colonists in São Paulo, Joinville, and Dois Córregos, to whom Stauffer had previously brought Adventism. Their conclusion was that converts were directly related to the activity of book salesmen. ${ }^{43}$

Gradually the church became more formally organized. The Brazilian Conference was organized in 1902 in a meeting in Gaspar Alto, Santa Catarina, with H. F. Graf as the first president. This was seven years after the organization of the first church. ${ }^{44}$ Besides the churches, by 1902 the church had nine schools, a clinic, and a printing press.

\footnotetext{
${ }^{42}$ Since they were not authorized to baptize or organize congregations, ordained ministers were in charge of that part, as Greenleaf points out, "when ordained personnel arrived to supervise the work, colporteurs happily relinquished their role as leaders to become cooperators in church activities." Greenleaf, The Seventh-day Adventist Church in Latin America and the Caribbean, 22.

${ }^{43}$ J. W. Westphal, "Brazil," Review and Herald, July 16, 1895, 11; J. W. Westphal, "Brazil, Uruguay, and Argentina," Review and Herald, October 1 1895, 12; Thurston, "Brazil," 11; Thurston, "Brazil," 27-28.

${ }^{44}$ Spies, "Organization of the Brazil Conference," 17.
} 
Although Westphal had been a leader of the work in South America from the beginning, it was after his appointment as the president of the South American Union in 1906 that the church experienced a special time of development of their institutions. He believed in the role of institutions and considered them his "children" to help in the spreading of the Adventist message. ${ }^{45}$

One of the main accomplishments during Westphal's term was local union control over finances. General Conference funds were now channeled through the union to different fields instead of to projects or missionaries. His plans were for each conference to support itself so the funds received would be invested in new fields according to local needs. ${ }^{46}$ In 1908 at a meeting with representatives from around the South American Union, Westphal attributed the church's progress to improved organization through institutional expansion. ${ }^{47}$

In 1911 an important step was taken in decentralizing the work in Brazil with the establishment of the Brazil Union. F. W. Spies was appointed the first president of the

${ }^{45}$ Greenleaf, The Seventh-day Adventist Church in Latin America and the Caribbean, 1:101.

${ }^{46}$ Greenleaf, A Land of Hope, 96. Greenleaf points out that "at that time the General Conference Committee acted as the budgetary watchdog for world fields, which meant that financial questions, including small requests, were matters that the General Conference decided. Thus, church headquarters retained control over the details of mission work.” Ibid., 37.

${ }^{47}$ J. W. Westphal, “The South American Union Conference," Review and Herald, June 11, 1908, 13. "Westphal saw membership increases and institution-building as two near-simultaneous aspects of church growth. This perception led him to centralize his financial resources and to exercise more effective administrative controls over organization machinery. ... By tracing the evolution of institutions we may see more clearly how Westphal's policies shaped the Adventist church.” Greenleaf, The Seventh-day Adventist Church in Latin America and the Caribbean, 1:96. Greenleaf points out that at the South American Union session in 1910, Westphal, among other changes, established institutional committees. That development is highlighted as a first step toward delegation of authority according to regional needs. Ibid., 1:101, 102. 
newly formed organization and announced that membership expansion was his priority. ${ }^{48}$

On November 18, 1915, the General Conference council delegates approved the organization of the South American Division to be located in Argentina, and asked 46year-old Oliver Montgomery to become its first leader. This seems to be an important milestone in the development of the church in South America, especially from the organizational perspective.

By the time the division was organized, everyone was impressed with the publishing house, which began in 1906 and was perhaps the best-operated institution in the entire field. It produced a large amount of literature for both the church and the nonAdventist public, especially doctrinal tracts and the monthly missionary magazine, Sinais dos Tempos, with a circulation of 20,000 by December $1918 .^{49}$ That development was severely affected by an unstable economy and World War I, and was restored by denominational assistance. Distributing denominational literature was a precondition of solid church growth in the minds of the leaders.

By 1926, the first Brazilian training school had had a promising beginning. The school had progressed relatively fast since its early years under the leadership of John Lipke, J. H. Boehm, and Paul Hennig. Enrollment was around 200 and faculty was departmentalized into a dozen fields. General educational work in Brazil, however, was

\footnotetext{
${ }^{48}$ Greenleaf, The Seventh-day Adventist Church in Latin America and the Caribbean, 1:120. In 1919, the second union in Brazil was organized: North Brazil Union.

${ }^{49}$ W. W. Prescott, "Under South American Skies-No. 1," Review and Herald, February 17, 1916; Town, "The Literature Work in Brazil." The missionary magazine was renamed in 1923 to O Atalaia, with a circulation of 13,000 two years later. J. Berger Johnson, "A Word from Brazil," Review and Herald, January 22, 1925.
} 
far behind what it should be. ${ }^{50}$ As Greenleaf comments, "consolidation and expansion lay ahead, but for South American Adventists, their times of beginnings were over. ${ }^{51}$

\section{Disciple-making for Eternity}

The typical disciple-making process, the last element of the Adventist movement ethos model, during the initial phase of the Adventist movement in Brazil began with a personal contact by a colporteur. Eventually those interested in the Adventist message received a visit by one of the pastors. Ministers often stayed a few days with the family and taught about the Bible. During those days they could visit other people who lived nearby and also study the Bible with them. The process often followed a pattern beginning with groups that were organized into Sabbath schools and later became churches. Westphal organized what was probably the first Sabbath school in Brazil, sometime in March or April 1895 at Indaiatuba, São Paulo. ${ }^{52}$

Two other dynamics were part of becoming an Adventist in the beginning. General meetings with church members were part of that experience. In May 1898, the first meetings were held in Curitiba. The schedule included 14 hours of meetings a day ending with additional preaching for ten days. After the organization of the Brazil Conference, the leaders organized seven general meetings throughout Brazil where they

${ }^{50}$ P. E. Brodersen, "Report of the South American Division," Review and Herald, June 6, 1926.

${ }^{51}$ Greenleaf, The Seventh-day Adventist Church in Latin America and the Caribbean, 1:122.

52، At Indaiatuba one family began to keep the Sabbath through reading. I baptized seven of the family and organized a Sabbath school. ... At Piracicaba we held meetings nearly three weeks.... We organized a Sabbath school and a missionary society, and celebrated the ordinances. It was the first quarterly meeting held by Seventh-day Adventists in Brazil. We also baptized five persons in the Piracicaba River." Westphal, "Brazil," 11. 
promoted schools, medical work, literature production and sales, revival, and evangelism. General meetings also had a uniting role. ${ }^{53}$

Colporteuring was more than an economic means for survival for the first missionaries, for literature distribution also became part of the experience of some of the new converts. In 1913, Spicer, General Conference secretary, while visiting South America, listened to cheering reports from the leadership of Northeast Brazil about "the fast-growing church in that region, noting that some of the new converts were getting a good experience in the colporteur work." 54

While in the early years the primary way of assessing Adventist expansion was literature distribution, it did not take long for that to change to membership growth. The arrival of more full-time ordained ministers in Brazil was responsible for a change in the focus of how to measure evangelistic success.

Institutions of the church were gradually introduced in the process of discipling believers. Despite the early discussion about using schools as a method of evangelization in South America, Adventists "were more prone to see the advantage education would be to retain the youth of the church and to train workers." The first primary Adventist school opened in 1896 in Curitiba. ${ }^{55}$ In 1897 the church established the first missionary school in

\footnotetext{
${ }^{53}$ W. H. Thurston, "General Meeting in Brazil," Review and Herald, August 9, 1898, 11; F. W. Spies, "General Meetings in Brazil," Review and Herald, February 4, 1904, 14-15.

${ }^{54}$ W. A. Spicer, "In the United States of Brazil," Review and Herald, June 27, 1912, 6-7. Alberto Bachmeyer is an example of a sailor who accepted the Adventist message and, even before getting baptized, began selling books in German in several cities in the state of São Paulo after being trained by Stauffer. The Seventh-day Adventist Encyclopedia.

${ }^{55}$ Greenleaf, The Seventh-day Adventist Church in Latin America and the Caribbean, 1:49; Thurston, "Brazil," 10-11. On July 1, 1896, a primary school opened in Curitiba, with William Stein and his wife as teachers and, within the first year, enrollment jumped from 8 to 100. Their primary goal was German-speaking Adventists but in January 1897 classes in Portuguese began to be offered. By 1901 Brazil
} 
Santa Catarina and later transferred it to Rio Grande do Sul where it stayed from 1903 to 1910. The missionary school was reopened in 1915 in São Paulo. ${ }^{56}$ The Adventist health message was also utilized along with evangelistic efforts in Brazil, but the overall feeling was that health institutions should come later in the process when there were enough people in the church to support them. ${ }^{57}$ The printing press played an especially significant part in the early years of the Adventist movement in Brazil because of its direct relation to literature evangelism. ${ }^{58}$ The unique characteristic of the publishing house was that while the schools had an inward focus, it had both inward and outward audiences.

Following is how Greenleaf explains the rationale of most church leaders of the time.

Because of this combination of spreading the word and practical finances, publishing establishments often drew strong support from the early leaders, who, at the same time, might debate the virtues of either a schools or sanitarium. Missionaries did not always understand these distinctive roles. While they generally accepted self-support

had one school designed for non-Adventists and four classified as church schools. Two years later a training school in Brusque had already been established; however, with time, some of those schools did not last. In 1905, Lula Gregory made a significant decision for the development of denominational schools in Brazil when she moved with her 14-year-old daughter, leaving her husband, from Taquari to a Portuguesespeaking community to work exclusively among them. W. H. Thurston, "A Trip to Southern Brazil," Review and Herald, April 6, 1897, 12-13; William Stein, "Our International School in Brazil," Review and Herald, April 20, 1897, 11; W. H. Thurston, "In Brazil," Review and Herald, April 23, 1901, 8-9; Stauffer, "Brazil," 11.

${ }^{56}$ The Seventh-day Adventist Encyclopedia. In 1915 John Lipke became the first director of a school of seventeen students that would eventually become Brazil College. F. W. Spies, "Brazilian Union Conference," Review and Herald, February 10, 1916, 10.

${ }^{57}$ Greenleaf, The Seventh-day Adventist Church in Latin America and the Caribbean, 108. An example of pioneering during this time is the story of Dr. A. L. Gregory and his wife Lula, who went to Brazil, to work side by side with church leaders. A. L. Gregory, "Brazil," Review and Herald, July 14, 1904, 15; A. L. Gregory, “Dentists as Missionaries," Review and Herald, August 31, 1905, 18.

${ }^{58}$ In January 1909 the Brazilian press completed a major move from Taquari to São Bernardo. Besides the lack of physical space at the previous location where it shared the same building with a school, the move was also influenced by the realization that Adventist institutions should be near large commercial and population centers. Greenleaf, The Seventh-day Adventist Church in Latin America and the Caribbean, 1:101, 102; J. W. Westphal, "General Meeting in the Sao Paulo (Brazil) Mission," Review and Herald, July $16,1908,17$. 
as a goal for Adventist institutions, they frequently were insensitive to a sequential pattern in membership growth and the founding of institutions. ${ }^{59}$

\section{Public Evangelism (1927)}

Contextual Dynamics in Brazil: Getúlio Vargas and the Estado Novo

The world economic crash of 1929 hit Brazil hard. Its economy became

vulnerable with the wide fluctuations in the price of commodities and its small number of trading partners. The economy was still primarily agricultural and only 25 percent of the population lived in the cities. Government economic policies did not help the situation, which led to much discontentment. In 1930 a military conspiracy deposed Washington Luís, the president, and passed power to Getúlio Vargas, a politician from Rio Grande do Sul who had run for president earlier that year. ${ }^{60}$

Vargas' government promoted agricultural products, created new enterprises, and invested in infrastructure, but it limited freedom. Media censorship, for example, was very active. During this time of contrasts, the industrial sector expanded, Brazilian women protested against discrimination and acquired the right to vote, and Vargas began funding samba schools in order to promote Brazilian carnivals as a tourist attraction. The Estado Novo (New State) period, as it became known, assumed an aggressive role in the economy. ${ }^{61}$

\footnotetext{
${ }^{59}$ Greenleaf, The Seventh-day Adventist Church in Latin America and the Caribbean, 1:63.

${ }^{60}$ Skidmore and Smith, Modern Latin America, 149, 155-156.

${ }^{61}$ Ibid., 159.
} 
Contextual Dynamics in the Church: Multiplying the Reach

The Great Depression affected more than the economy of Brazil and,

consequently, the budget of the church. It also had a very positive impact on the number

of baptisms. ${ }^{62}$ That was not a unique South American phenomenon, since the

denomination experienced a similar trend worldwide.

In spite of economic problems and nationalism, the church did not collapse. Probably no stronger unifying influence existed than the evangelistic purpose that constituted the church's raison d'etre. As pronounced as the materialistic tendencies became during the 1930s, they served to emphasize the virtue of the gospel commission and the ultimate goal of all workers, no matter what their personal background or what their salary and perquisites. ${ }^{63}$

\section{Mission Method}

Public evangelism was the second major strategy of evangelization introduced in Brazil. Gradually church leaders become attracted to the possibility of multiplying the reach of their efforts, especially as they searched for efficient methods to reach people in the already large cities of Brazil. ${ }^{64}$ Timm suggests 1927 as the milestone year since public evangelism was widely adopted in that year by the South American Division under the motto "every convert a convert maker." ${ }^{\prime 65}$ Nonetheless, Greenleaf points out that one of the first attempts to conduct large-scale urban evangelism was in connection with L. R.

\footnotetext{
${ }^{62}$ During 1931-1935, "the church grew 13 percent more rapidly than during the previous five-year period." Greenleaf, A Land of Hope, 300; General Conference of Seventh-day Adventists, Annual Statistical Reports, 1925-1940 (White Estate, Silver Spring, MD: Author).

${ }^{63}$ General Conference of Seventh-day Adventists, Annual Statistical Reports, 1925-1940, 307.

${ }^{64}$ Spies pointed out that "ever since the work of presenting the third angel's message to Brazil's millions began, the question of how to reach the inhabitants of the large cities ha[d] been studied." $\mathrm{F}$. W. Spies, "Tent Meetings in Brazil," Review and Herald, April 29, 1915, 12.

${ }^{65}$ Timm, "Building a Growing Church."
} 
Conradi's visit in 1911. The rationale was that "if successful, this method would increase members at a faster rate than private, door-to-door literature distribution followed by individual Bible studies."

One of the first actual experiments with public meetings in Brazil happened in 1914 by John Lipke in Santo Amaro. A large-scale evangelistic series was conducted in connection with the annual Brazil Union Session. There were meetings on three evenings a week and the rest of the time was for visiting and tutoring. One of the weekly meetings was a health lecture, including lessons in cooking and hydrotherapy treatments. After four months of meetings they baptized 20 people. While auditoriums were not always easy to rent, tents were shown to be attractive to large audiences ranging from 135 to 400 people. ${ }^{67}$ By the time the South American Division organized in 1916 the method of evangelization in Brazil had shifted from "an almost exclusively rural, literature-oriented process to experiments with urban evangelistic teams, the forerunners of large-scale metropolitan crusades." 68

\section{Jesus: Lord, Savior, and Priest and Missional-Incarnational Impulse of the Coming of Jesus}

Public evangelism combined Jesus as Lord, Savior, and Priest and an emphasis on the coming of Jesus - two elements of the Adventist movement ethos model. During the development and implementation of public evangelism as a mission method in Brazil

\footnotetext{
${ }^{66}$ Greenleaf, A Land of Hope, 116. After his visit, pastors started to invite ordinary people from the street into meetings where a series of doctrinal lectures would be presented, followed by personal instruction, and baptism. L. R. Conradi, "In South America," Review and Herald, March 9, 1911, 8.

${ }^{67}$ John Lipke, “Sao Paulo (Brazil) Mission,” Review and Herald, September 3, 1914, 12.

${ }^{68}$ Greenleaf, A Land of Hope, 118.
} 
experiments with different ways to present the Adventist message were conducted in order to be relevant to the local context. Despite excitement with public evangelism and its ability to reach large audiences, evangelists were challenged to find new ways to present the Adventist message to Brazilians. "Up to the 1940s, public evangelism in South America followed largely the Protestant apologetic approach, [that was] not well received by the predominantly Roman Catholic population." ${ }^{99}$

South American evangelism began in a North American mold in which prophecy played a prominent role in opening evangelistic meetings. Prophetic exposition served two purposes: it attracted the attention of the listener and it established the veracity of the Bible. While that approach had functioned well for many years in a North American setting where evangelistic meetings resembled weekly Sunday worship services, it did not fit as well in a different cultural milieu such as Latin America. $^{70}$

Contextualization concerns led Walter Schubert to seek a South American approach to public evangelism. Specifically, he was interested in meeting audiences' felt needs and building bridges before getting into the distinctive doctrines of Adventists. A turning point happened when he was challenged by a church member during one of his evangelistic series in Argentina.

Following a disappointing experience with her relatives' attendance at his meetings, a disturbed sister in the church accosted Schubert about his methods - singing evangelical songs, praying, and even taking offerings during his meetings. In her view these activities forced non-Adventists to practice Adventism before they were ready to adopt it. "You should hold meetings in the form of lectures like university professors do," she told him. ${ }^{71}$

After spending the night thinking about that recommendation, Schubert called a

\footnotetext{
${ }^{69}$ Timm, "Building a Growing Church."

${ }^{70}$ Greenleaf, A Land of Hope, 483.

${ }^{71}$ Ibid., 399.
} 
meeting with area pastors to discuss the idea. In his next meetings he experimented with topics of social interest instead of his traditional prophecy sermon. The title of his lecture was "The Secret of Happiness." The reaction was obvious since the audience applauded Schubert several times during his presentation and twenty people requested personal appointments with him. He gradually introduced biblical themes, doctrinal questions, and Adventist practices. He also prioritized communities that had received the seed of the Adventist message through literature. Schubert made a list of seventy communities in the division with a population of at least 5,000 where literature had been sold but where 
Adventists ministers had never preached. Schubert's method became the standard and "by the early 1940s, it became clear that urban evangelism had become a movement."72

Schubert's series began with a classic and religious music concert, followed by a lecture series on world problems; then another on the solution to the difficulties people face, and another on human relations. Finally, he introduced the great truths of the Bible with terminology familiar to his Roman Catholic audiences. ${ }^{73}$

Schubert's experiments motivated others to conduct their public meetings in creative ways. ${ }^{74}$ Evangelists seemed to understand the basic principle Schubert stressed: "In a socially conscious society, human issues will capture the attention of the public more effectively than Bible prophecy."75

In 1957, G. G. Oliveira, another prominent evangelist, demonstrated other ways of connecting evangelistic meetings with the community in practical ways. A local small congregation in Cuiabá was spiritually stagnant and met in a rundown building. During the meetings, which met in a rented space for five hundred people in the center of the city, Oliveira promoted a campaign to rebuild the church. As result, besides fifty-nine new converts, church members developed a renewed spiritual interest. ${ }^{76}$

The next two decades were characterized by the wide-spread use of evangelistic

\footnotetext{
${ }^{72}$ Greenleaf, A Land of Hope, 400.

${ }^{73}$ Daniel Belvedere, Revista Adventista (Argentina), May 1981, 19, quoted in Timm, "Building a Growing Church.”

${ }^{74}$ In 1946, a worker preached on the streets of Barra Alegre (Rio-Espirito Santo Mission) because he could not find a proper meeting place. In Rio de Janeiro, Adventists used a truck equipped with a public address system, a movie projector, and a screen to attract large crows wherever it went. A. C. Harder, "RioEspirito Santo Mission," Review and Herald, November 7, 1946, 18; J. Ernest Edwards, "Evangelism by Truck in Rio," Review and Herald, July 15, 1948, 24.

${ }^{75}$ Greenleaf, A Land of Hope, 483.

${ }^{76}$ Geraldo G. Oliveira, "Evangelizing the Heart of South America," Review and Herald, February 27, 1958, 19-20.
} 
campaigns and the rise of important public evangelists. Two of these prominent evangelists were Alcides Campolongo and Enoch de Oliveira. At one of the first campaigns in Rio de Janeiro in 1963, Oliveira presented lectures on health, the home, and juvenile delinquency, besides regular Bible classes. Campolongo also introduced his series with public discussions about health, alcoholism, and tobacco, and gradually moved to religious topics. Church members helped in the preparation by enrolling thousands in radio and television correspondence schools. ${ }^{77}$ Based on the size of the meetings and number of baptisms, it is reasonable to infer that there was an increased dependence on evangelism in the 1970s. By 1980, another generation of evangelists continued to look for new ways to contextualize their meetings, "but the practice of tailoring the format of the gospel to fit the needs of the audience was always the undergirding principle of evangelistic method."78

\section{Apostolic Environment within the Great Controversy}

An interesting dynamic concerning an apostolic environment in public evangelism, an element of the Adventist movement ethos is the ways in which church members became involved. During the first decades of the Adventist movement in Brazil scarcity of ministers forced lay people to be prominent in the church's plans to reach a

\footnotetext{
${ }^{77}$ C. Nunes Vieira, "Rio de Janeiro on Fire for Evangelism," South American Division Bulletin, October-December 1963, 3-5; Roberto C. Azevedo, "The Largest Baptism," South American Division Bulletin, April-September 1964, 9-10; Roberto C. Azevedo, "Brazil's Biggest Baptism," Review and Herald, June 29, 1961, 1, 5; Alcides Campolongo, "Hundreds Respond to São Paulo Evangelism," Review and Herald, Fabruary 15, 1968, 18-19; Moisés S. Nigri, "1967: O Melhor Ano da Divisão Sul-Americana," Revista Adventista, July, 1968, 5-6. Moisés S. Nigri, "This Is the South American Division," South American Division Bulletin, April-June 1967, 5-6.

${ }^{78}$ Greenleaf, A Land of Hope, 629.
} 
rapidly increasing population. When W. A. Butler from the Home Missionary

Department of the General Conference visited South America in 1938 he said the

division was on the "verge of the greatest lay movement South America has seen.

Hundreds of our lay brethren are actively engaged in giving Bible studies and holding lay efforts." ${ }^{79}$

After World War II, the South American Division prioritized educational and organizational programs for lay people. Part of Schubert's strategy was to hold field schools for workers who assisted him. He would share responsibilities with them while he conducted evangelistic meetings, sometimes in two different locations in a single city or in two different towns near each other. Workers who went through Schubert's training often became so motivated that, after assisting him in one campaign, they would proceed to become an itinerant evangelist and organize evangelistic meetings on their own.

Medical personnel were also often part of the evangelistic team and helped in presenting health lectures.

The early 1950s witnessed a major division evangelistic thrust based on the desire to give the Adventist movement new momentum. That initiative included an orientation to help members conduct evangelistic campaigns and it suggested that small churches should hold revivals lasting from ten to fourteen days to attract marginal members and former Adventists. Training lay people resulted in a large mobilization in 1953 and in

\footnotetext{
${ }^{79}$ W. A. Butler, "Progress in South America," Review and Herald, July 14, 1938, 19. Examples of lay-led evangelistic initiatives include a five-month project in a congregation in Rio de Janeiro in 19331944 and another congregation in São Paulo that had its membership doubled in two years inyhe early 1940s. C. C. Schneider, "The Lay Missionary Movement in the East Brazil Union," Review and Herald, June 21, 1934, 9-10; H. B. Westcott, "A Greatly Appreciated Layman," Review and Herald, June 21, 1934, 15.
} 
1957 the strategy was repeated with the result that 4,000 out of the division's 10,000 baptisms were at least partially attributed to laity. ${ }^{80}$

In the 1960s support programs for urban evangelism, such as anti-tobacco and anti-alcoholism campaigns, were developed and conducted mainly by lay people. R. E. Adams developed an initiative that trained and equipped lay people with films and projectors and 1971 was once again dedicated as the "Year of the Layman."

In 1970 Daniel Belvedere introduced another form of public evangelism that mobilized lay people. Preaching every evening during the week prior to Easter in Argentina, his experiment became known as Holy Week evangelism and was adopted around the Division. Belvedere's pilot program organized 147 parallel series in several neighborhoods, involved 262 lay preachers, was supported by around 600 lay people, and had more than 4,300 non-Adventists in attendance. ${ }^{82}$

\footnotetext{
${ }^{80}$ W. E. Murray, "The South American Division," Review and Herald, November 6, 1952, 13-14; Idem., "Public Evangelism in Cachoeira, Brazil," Review and Herald, September 29, 1955, 19. The large mobilization of 1953 resulted in 104 campaigns and 344 baptisms. Four years later a new Manual for Lay Workers was produced. J. Ernest Edwards, "South American Evangelistic Crusade," Review and Herald, February 28, 1957, 32; T. L. Oswald, "Lay Evangelism in South America," Review and Herald, March 27, 1958, 19-20. "Those plans also affected church pastors since, at their annual session in 1953, they voted to allow pastors seven to eight months of uninterrupted evangelism in order to focus on their primary responsibility." Santiago Schmidt, "Lay Evangelism in the East Brazil Union," Adventist Review, June 18, 1953, 15-16; R. E. Adams, "Lay Preachers to the Front in East Brazil," Review and Herald, October 8, 1953, 13; A. V. Olson, "The Lay Preachers of Brazil," Review and Herald, January 14, 1954, 18-19; L. H. Olson, "Excerpts from the Report of the Secretary," South American Division Bulletin, January-February $1954,2$.

${ }^{81}$ R. E. Adams, "Laymen Win Hundreds in South Brazil," Review and Herald, August 10, 1961; J. Ernest Edwards, "South Brazil Distributes One Million Tracts," Review and Herald, July 20, 1961, 24; Moisés S. Nigri, "Para Que O Mundo Conheça," Revista Adventista, March 1971, 9-11.

${ }^{82}$ Timm, "Building a Growing Church."
} 


\section{Spiritual Organic Systems}

Developments in spiritual organic systems, an element of the Adventist movement ethos model related to church organization, followed the denominational emphasis on public evangelism. One of the major concerns was the training of ministers and lay evangelists. Early on, that task was a responsibility of training schools. In 1927, General Conference Field Secretary G. W. Schubert pointed out that those were "the most important places in every conference or mission field" because of their role in the conversion and education of young people. ${ }^{83}$

Two denominational leaders were key in the development of public evangelism as a mission method in Brazil. The Carlyle B. Haynes era as president of the South American Division (1926-1930) marked a change in attitude in many ways. Haynes had two major emphases: self-support and urban evangelism. The combination of these two was envisioned in the activity of evangelists among new members of means who lived in the cities. Without neglecting the poor, he believed that the results of urban evangelism would allow the division to advance in other areas, including among the indigenous population. Haynes also implemented a different view of the church's organization that impacted Adventist mission in Brazil. He molded the "organization and its many parts into a rational, comprehensive unit" and "inspired his subordinates to believe in

${ }^{83}$ G. W. Schubert, "Experiences in South Brazil," Review and Herald, February 9, 1928, 17. In 1934, E. H. Wilcox, South Brazil Union president, became excited at the realization that two former students of Brazil College had assumed preeminent roles in evangelistic meetings, a sign of the success in training workers for evangelism. E. H. Wilcox, "Reuniões Geraes em Matto Grosso," Revista Adventista, September 1934, 14-15. 
themselves and to aspire to a legitimate independence within the framework of world Adventism." 84

Another key denominational leader was Walter Schubert, the evangelist who demonstrated the significance and applicability of that method. By the second half of the 1930s, Walter Schubert had earned the reputation as the division's premier evangelist and became known as "Mr. Evangelism." Schubert began experimenting with small changes to traditional evangelism in the 1920 s in Chile, had a major breakthrough while working in Argentina, and was able to introduce his method throughout Brazil after joining the division team. ${ }^{85}$

\section{Community for God and Disciple-making for Eternity}

Two elements of the Adventist movement ethos model were combined in public evangelism: disciple-making happened in the context of community. As the Adventist community grew new dynamics in disciple-making were developed. One of the most important spiritual dynamics that offered opportunities for spiritual growth in Brazil was Missionary Volunteer (MV) societies. Between 1926 and 1940, the South American share of MV societies grew from 4 to 10 percent, at least in part, due to the excitement of

\footnotetext{
${ }^{84}$ Carlyle B. Haynes, "The South American Division," Review and Herald, June 11, 1930, 186189. While asking for continuous financial support by the General Conference, he defended the idea that mission funds should not be consumed on routine operations but on new mission initiatives. As Greenleaf points out, Haynes "was convinced that not only South Americans but the entire Adventist world had much to learn about the principles of operating a global program among peoples in widely diverse conditions that shaped their social and psychological makeup as well as their financial capabilities." Greenleaf, A Land of Hope, 273.

${ }^{85}$ Rúben Pereyra, "História da Evangelização na América do Sul," Revista Adventista, October 1976, 16-18. It becomes clear that the choice and promotion of public evangelism as the main mission method in Brazil, beginning in 1927, originated at the denominational headquarters at the division level.
} 
local youth leaders. Youth congresses during the 1930s demonstrated that the vast majority of Adventist youth was not enrolled in denominational schools, and for many of them, their primary contact with the church was through the MV Society, making it a channel of informal education in Adventist values and teachings. ${ }^{86}$

Most public evangelism initiatives were successful not only in reaching out to people in the community but also in fostering evangelistic fervor. ${ }^{87}$ Over time the range of evangelistic programs and opportunities became much broader and more available to church members, but one fundamental disciple-making idea that characterized this period was the keeping of the local congregation as the center of missionary efforts. Greenleaf highlights the idea of the congregation as the central agent of evangelism by referring to a report of the 1940 Division Council. "The entire two-page statement elaborated on the soul-winning potential of Sabbath schools, youth ministry temperance activities, and colporteur endeavors without mentioning institutional matters." 88

After reviewing the ethos of the Adventist movement in Brazil during the first two periods, in the next chapter, the same historical account will focus on the next three mission methods.

${ }^{86}$ Greenleaf, A Land of Hope, 390.

${ }^{87}$ Holy Week evangelism is a good example of that. During the whole week prior to Easter evening evangelistic meetings presented themes related to the last week of Jesus on earth. Besides providing a good opportunity to reach out to Catholics, host congregations were also benefitted by offering opportunities for leadership development and growth in public-speaking, while "energizing existing members and sometimes bringing a healing balm to the discouraged and the contentious." João Wolff, "The Lord Has Done Great Things for Us," Adventist Review, July 1, 1985, 17-19; Ruy Nagel, "Our People on the March," Adventist Review (2000), accessed November 3, 2010, www.adventistreview.org/2000bulletin4/8-report-south-america $\cdot$ html.

${ }^{88}$ Greenleaf, A Land of Hope, 642; "Importantes Resoluções do Concílio de 1940 da Divisão SulAmericana," Revista Adventista, March, 1941, 3-4. 


\section{CHAPTER 8}

\section{THE ETHOS OF THE ADVENTIST MOVEMENT IN BRAZIL}

BETWEEN 1943 AND 2007

\section{Radio and Television Evangelism (1943)}

The third mission method widely adopted in Brazil was radio and television evangelism. This third wave was the result of excitement about the possibility of reaching large audiences with the Adventist message and experiments with radio broadcasting in the United States and in South America, which led Brazilian church leaders to adopt this new method.

\section{Contextual Dynamics in Brazil: The Second Republic and Military Rule}

The early 1940s witnessed new political developments in Brazil. The expected elections were not held in 1943 by the authoritarian Vargas government. Brazil did not participate very actively in World War II, but after breaking diplomatic relations with Germany in 1942, it did provide the Allied with raw materials, air and naval bases, and a combat division in Italy in 1944. In exchange, Vargas worked out a deal whereby the United States promised to help finance the industrialization of Brazil. ${ }^{1}$

During the first half of that decade, the government also tended toward populism

${ }^{1}$ Skidmore and Smith, Modern Latin America, 159. 
by focusing on issues of the urban working class. The 1943 Labor Code guaranteed some benefits to workers. That and other leftist political measures helped polarize the situation that climaxed in October 1945 when the army gave Vargas an ultimatum: resign or be deposed.

Between 1946 and 1964, Brazil was governed by the Second Republic. A new constitution in 1946 introduced representative democracy. Enrico Dutra took measures to attract foreign investment during his government and Vargas became president again in 1950; this time, by election. After years of economic instability and finding himself politically isolated, Vargas committed suicide. This period also had one of the most progress-oriented and charismatic presidents in the history of Brazil, Juscelino Kubitschek, and one of the most populist and excentric ones, Jânio Quadros. João Goulart, vice-president, assumed the presidency after Quadros' resignation. He tried to deal with the high levels of inflation and dissatisfaction among the military but his government soon collapsed.

From 1964 to 1985 Brazil was under military rule and was governed by a succession of authoritarian regimes. During the first government inflation was reduced and during the second government the economy started growing. The dark side of this period was the levels of political violence and authoritarianism. The second half of the 1970s witnessed the beginning of a process of redemocratization. ${ }^{2}$

Contextual Dynamics in the Church: Navigating Instability

World War II and the difficult relations with Germany caused issues for the many

${ }^{2}$ Skidmore and Smith, Modern Latin America, 161-173. 
German church workers and members. The roots of those problems included inflamed patriotism, traitorous accusations, disloyalty, release from military duty on Sabbath, and non-combatant status. In different regions mobs destroyed homes and possessions, and several Adventists were imprisoned for being of German descent. ${ }^{3}$

Besides social issues, the economic hardship resultant from the war also affected the church. Indebtedness was high and monetary reserves were low. The only "benefit" produced by the war was that pessimism caused people to be more receptive to biblical preaching on prophecy and the second coming of Jesus. ${ }^{4}$

Church leaders worked hard to establish a reliable reputation with the federal government. In 1950 Adventist ministers met with Getúlio Vargas to present the church's disaster relief and civic projects, its non-combatancy in military service position, the Medical Cadet program, the Sabbath doctrine, the nature of denominational organization, and religious liberty ideals. The government and the army especially supported the Adventist program of Medical Cadet Corps even after theVargas presidency. That program enrolled hundreds of Brazilian army recruits, including Adventist youth. ${ }^{5}$

Between 1950 and 1970 the number of overseas employees diminished sharply and the number of ordained ministers rose. Beginning in 1963 nationals began to be

\footnotetext{
${ }^{3}$ Greenleaf, The Seventh-day Adventist Church in Latin America and the Caribbean, 2:192-193.

${ }^{4}$ Timm, "Building a Growing Church." The Division membership had a 72 percent net increase during that decade.

${ }^{5}$ Greenleaf, A Land of Hope, 597-602. See also: F. N. Siqueira, "Serving Our God and Our Country in Brazil," Review and Herald, June 9, 1955, 20-21; H. Eugene Walker, "Medical Cadet Camp in North Brazil," Review and Herald, August 25, 1955, 20; Domingos P. da Silva, "Brazil Army Helps Give Medical Cadet Training," Review and Herald, July 19, 1956, 22; H. J. Peverini, "Brazilian Medical Cadet Complete Course at College," Review and Herald, May 9, 1974, 22.
} 
assigned to leadership positions. In 1975, Enoch de Oliveira became the first Brazilian division president.

\section{Mission Method}

As early as 1924 experiments with small-scale radio broadcasting of Adventist programs were being made in South America. Radio broadcasting took different forms in different places and times regarding time, content, power, and response, but it became more and more significant. In 1942, Adventist lectures were broadcast by a chain of eleven stations in Uruguay, including one of the most powerful on the continent. The correspondence school organized for the broadcasts had almost a thousand students. By that time, H. M. S. Richards' Voice of Prophecy was already being broadcast across the North American continent and the General Conference was convinced that it was the appropriate time to plan large radio broadcasts in South America. In 1943 the Voice of Prophecy aired for the first time in South America and Roberto Mendes Rabello, an ordained pastor on study leave in the United States, became the speaker of the Brazilian version of the Voice of Prophecy. ${ }^{6}$ This program received much attention as the first religious program to be broadcast nationally. ${ }^{7}$

Twenty years after the beginning of radio broadcasts, Faith for Today (Fé para Hoje), the first Adventist Brazilian television program launched in 1962 featuring

${ }^{6}$ J. L. Brown, "The Radio in South America," Review and Herald, August 9, 1934, 11; J. F. Wright, "Evangelism in South America," Review and Herald, August 13, 1942, 24; Roberto Rabello, "A Voz da Profecia," Revista Adventista, March, 1944, 8-9; W. E. Murray, "Growth of Our Radio Work in South America," Review and Herald, March 12, 1953, 17.

${ }^{7}$ In 1962, even Juscelino Kubitscheck, president of Brazil, attended the dedication ceremony of the new operations building in Rio de Janeiro. Greenleaf, A Land of Hope, 487. 
Brazilian evangelist Alcides Campolongo as its speaker. By 1964 programming had expanded to 505 weekly broadcasts and six telecasts. ${ }^{8}$ In 1975 Brazilians also began producing Uma Luz no Caminho, a Portuguese version of Enrique Chaij Spanish program that had already been broadcast for 11 years. Five years later Encontro com a Vida began in Brazil. These were five-minute TV spots devoted to social, inspirational, and sometimes doctrinal issues. ${ }^{9}$ In November 1991, through the combined effort of some Brazilian businesspeople, the program It Is Written started being aired nationally. ${ }^{10}$

In 1965, in a one-paragraph description of the Adventist Church in Brazil, William R. Read highlighted that churches were present in "practically every state" in Brazil, the denomination ran "a unique training school" in Sao Paulo, and its radio program was heard "all over" and was "well appreciated." He observed that the growth of the Adventist Church was only happening among a few other evangelical denominations at the time. ${ }^{11}$

\section{Jesus: Lord, Savior, and Priest}

The first element of the Adventist movement ethos model is evident in radio and television evangelism. A common perception was that radio broadcasting and the

\footnotetext{
${ }^{8}$ Roberto Rabello, "Radio and Television in Brazil," Review and Herald, November 10, 1966, 18 ; F. C. Webster, "The Radio-Tv Ministry in South America," Review and Herald, April 21, 1966, 17-18; Moisés S. Nigri, “Grandes Coisas Fez o Senhor por Nós,” Revista Adventista, May, 1966, 4-5, 50; David Moroz, "Pregando para um Auditório de Cem Mil Pessoas," Revista Adventista, August 1968, 21-22.

${ }^{9}$ Greenleaf, A Land of Hope, 666. Leo Ranzolin, Uma Voz Dedicada a Deus: A Vida de Roberto Rabello (Tatuí, SP, Brazil: Casa Publicadora Brasileira, 2007), 152; “A Voz da Profecia: 40 Anos de Evangelismo Radiofônico,” Revista Adventista, September, 1983, 18-19.

${ }^{10}$ The Seventh-day Adventist Encyclopedia, s.v. "Brazil."

${ }^{11}$ William R. Read, New Patterns of Church Growth in Brazil (Grand Rapids, MI: W. B. Eerdmans, 1965), 206.
} 
opportunity to announce the gospel to an even larger audience than the previous two mission methods "literally corresponded to the prophecy of the spread of the gospel"12 in preparation for the soon return of Jesus, ${ }^{13}$ which was aligned with distinctive themes of Adventist theology.

Lylon H. Linbeck, director of the Voice of Prophecy for the division, used an analogy to explain his vision for radio broadcasting. Picturing eschatological aspects of the Great Controversy, he suggests that just as air forces had had an important role in the war, the Voice of Prophecy would also have an impact in the war against Satan.

With the addition of this modern means of communication, a new day surely rises for the proclamation of the third angel's message with haste, in South America, through the radio, this "gospel of the kingdom," as a powerful angel "flying in midair." Knowing that the Lord's day is near, how glad we should feel about another instrument to proclaim this blessed message to millions! ${ }^{14}$

\section{Missional-Incarnational Impulse of the Coming of Jesus}

The missional-incarnation impulse element of the Adventist movement ethos model was present in radio and television evangelism in specific ways. Incarnational dynamics were necessary in order to increase the effectiveness of this mission method. Originally the radio programs broadcast in Brazil followed scripts that were translated from English with minor adaptations. Eventually Rabello began producing his own

\footnotetext{
${ }^{12}$ Greenleaf, A Land of Hope, 413; Lylon H. Lindbeck, "O Progresso de Nossas Irradiações," Revista Adventista, March 1944; J. F. Wright, "The Voice of Prophecy Broadcast-South America," Review and Herald, March 23, 1944, 19-20.

${ }^{13}$ Lylon H. Lindbeck, “Levanta-Te, Resplandece, Porque Já Vem a Tua Luz,” Revista Adventista, Abril 1944, 6-7.

14““A Voz da Profecia Irradiada na América do Sul,” Revista Adventista, January 1943, 32.
} 
content. ${ }^{15}$ After recording Voice of Prophecy broadcasts in California for 20 years, production finally was moved to Brazil. A Brazilian male quartet was formed to sing in place of the North American King's Heralds and Del Delker's recordings in Portuguese. ${ }^{16}$

Besides adaptations related to translation, over time there were changes in format

to better fit local audience interests. The length of the programs shrank to fifteen and then to five minutes, while the subjects focused more on spiritual values than doctrine, leaving biblical instruction to the correspondence lessons. ${ }^{17}$ Bible study series were also contextualized. ${ }^{18}$

The missional dynamics of radio and TV evangelism were especially effective because they were able to cross geographic and social boundaries, even though sometimes their impact was hard to quantify. ${ }^{19}$ In an assessment conducted after three

\footnotetext{
${ }^{15}$ Further contextualization initiatives included the attempt to broadcast the Voice of Prophecy in Japanese for the Brazilian community of Japanese in 1959 and the creation of Stimme der Hoffnung ("Voice of Hope") with Jorge Hoyler for the German-speaking population of southern Brazil.

${ }^{16}$ Henry Feyerabend, "New Voice of Prophecy Studies in Brazil," Review and Herald, May 7, 1964, 26; Greenleaf, A Land of Hope, 487. In 1953 the Voice of Prophecy in Portuguese, produced by Rabello, was aired in Angola for the first time. Carlos Augusto de Morais, "Notícias de Angola," Revista Adventista, October 1953, 6.

${ }^{17}$ Milton Peverini Garcia, Vida de Braulio Pérez Marcio Fundador de La Voz de la Esperanza: De Incrédulo a Campeón del Evangelio (Nampa, ID: Pacific Press, 2007), 252. Another initiative was the production of local programs such as Moments of Meditation ("Momentos de Meditação"), Moments of Reflextion ("Momentos de Reflexão"), Good News ("Boas Notícias"), Afternoon Meditations ("Meditações Vespertinas"), and Moments for the Soul ("Momentos para a Alma"). Some of these programs were broadcast right before Voice of Prophecy. Apparently they helped in capturing the listeners' attention and preparing them for the doctrinal/prophetic message that came later. J. R. dos Passos, "Associação Paraná-Santa Catarina," Revista Adventista, September 1945, 12. Geraldo G. Olivera, "Relação de Programas Locais de Rádio na Associação Paulista," Revista Adventista, July 1945, 6; "Boas Novas," Revista Adventista, January 1948, 32.

${ }^{18} \mathrm{New}$ sets were developed for adults and teenagers, and the general course was felt to be more appropriate for those with more education. Lylon H. Lindbeck, "Os Progressos da Voz da Profecia na Divisão Sul-Americana," Revista Adventista, September 1946, 3.

${ }^{19}$ On the one hand the Voice of Prophecy made the Adventist Church known in many communities. In the North of Brazil, people reported that when they met strangers during a first contact, as
} 
years of programing, it was concluded that the broadcasts had thousands of listeners and thousands of students, but one of the most celebrated accomplishments was that prejudice had been broken down by the program. Many church members also had their own faith strengthened. As Rabello pointed out at the time, "the Adventist movement is seen in a new light, which we believe to be the true light." ${ }^{20}$ On the other hand, in 1952, after ten years of broadcasts and with more organized operations, it was estimated that 50 percent of the families who owned a radio in Brazil had never heard about the Voice of Prophecy. $^{21}$

Toward the end of this period, a new concern impacted evangelistic planning. Division President Enoch de Oliveira called for new methods that would be far-reaching and effective and for the need to mobilize to penetrate the entire continent. At the division meetings in 1977 , the committee vowed to make 1978 the year of penetration after hearing a report about 230 communities that had never heard of Adventism. This penetration project became Oliveira's main mission initiative and was carried out until $1980 .^{22}$

The riverboat ministry on the Amazon, which grew significantly during the 1940s, encapsulated the three main aspects: evangelism, education, and medical services.

soon as they identified themselves with the radio program they were able to develop friendships. J. Baerg, "Boa Identificação," Revista Adventista, September 1945, 23.

${ }^{20}$ Roberto Rabello, "Frutos da Voz da Profecia no Brasil,” Revista Adventista, July 1947, 3-5.

${ }^{21}$ Roberto Rabello, “Novo Dia para o Rádio-Evangelismo,” Revista Adventista, April 1952, 9.

${ }^{22}$ Greenleaf, A Land of Hope, 482, 543; Arthur S. Valle, "Penetration Is 1978 Goal," Review and Herald, August 18, 1977; Enoch de Oliveira, "Dispersão, Penetração e Explosão," Revista Adventista, January 1977. 
The ministry, which started in 1931 with the iconic Luzeiro, survived the financial crash of the Great Depression, received new and larger boats and more personnel in order to minister to even larger areas. This medical-evangelistic program aimed at the riverside population was initially developed by Leo B. Halliwell and his wife Jessie who were also able to create denominational interest in both the South and North America. ${ }^{23}$ The Halliwells demonstrated unique anthropological understanding in ministering to the native population. As Leo reports, "We had not come to impose by force of fear our ideas or culture or dogmas; we had come to help other human beings." In order to accomplish their mission, they "learned their language and customs and traditions; [they] became truly Brazilian. [They] thought, spoke, even dreamed in Portuguese." The Halliwells of the Amazon became an Adventist legend. ${ }^{24}$

\section{Apostolic Environment within the Great Controversy}

An apostolic environment, another element of the Adventist movement ethos model, was also present in radio evangelism in different ways. Church leaders were aware of the importance of the human factor in radio work that was often impersonal. Church members were motivated to pray for and advertise the program among their

\footnotetext{
${ }^{23}$ Leo B. Halliwell, Light in the Jungle: The Thirty Years' Mission of Leo and Jessie Halliwell Along the Amazon (New York: David McKay, 1959), 57-66; Leo B. Halliwell, Light Bearer to the Amazon: Thrilling Stories of Missionary Labors (Nashville, TN: Southern Publishing, 1945), 11-12; J. P. Lobo, "New Launches for the Amazon," South American Division Bulletin, May 1942, 7-8. Halliwell began his ministry as mission director in Bahia in 1921. E. H. Wilcox, "The Bahia Mission, East Brazil," Review and Herald, February 2, 1928.

${ }^{24}$ Leo B. Halliwell, “As Atividades da Lancha “Luzeiro,” Revista Adventista, June 1941, 32.
} 
friends in creative ways. ${ }^{25}$ They would leave flyers on city buses, advertise in local newspapers, call people randomly from the local phone directory, ${ }^{26}$ and distribute time schedules with a list of stations for the broadcast (provided by the local conference). They were instructed to tune in every week and write to their local stations complimenting the program as listeners so they would keep the Voice of Prophecy on the air. ${ }^{27}$ Adventists were also advised that in their contact with the community they should limit identifying the Voice of Prophecy with the Adventist Church to avoid any prejudice connected with the denomination. ${ }^{28}$ This caused reactions such as an important person who wrote a letter of appreciation to the program and ended it with a question: "What religion is this? I am following it without knowing what it is because I think it is the true one." 29

Over time church leaders found ways of coordinating the radio program with local congregations. ${ }^{30}$ Church members took advantage of the contacts made during the

\footnotetext{
${ }^{25}$ Santiago Schmidt, "O Fator-Homem na Obra do Rádio," Revista Adventista, July 1945, 4. In 1944, a special leaflet about the correspondence studies was produced for church members to hand out from door to door everywhere. May 13th, 1944, was chosen as a day for a special offering for radio evangelism. Lindbeck, "O Progresso de Nossas Irradiações," 7.

${ }^{26}$ Santiago Schmidt, "Sugestão de Amigo," Revista Adventista, March 1947, 7.

27“"A Voz da Profecia Irradiada na América do Sul,” 32; Lylon H. Lindbeck, "A 'Ofensiva Aérea' na América do Sul," Revista Adventista, August 1943, 10.

${ }^{28}$ Roberto Rabello, “Uma Porta Aberta," Revista Adventista, July 1944, 12.

${ }^{29}$ Harley Boehm, "Ressonância da Voz da Profecia," Revista Adventista, July 1945, 7. During the early years of the Voice of Prophecy in Brazil,when people had limited access to radio broadcast, church members who did not have a receiver were told that they should gather at the house of a non-Adventist who owned one. That would be a way of evangelizing them. "A Voz da Profecia," Revista Adventista, April 1943, 32. In some Adventist and Protestant churches, members and friends would arrive earlier than usual to the Sunday night meeting to listen to the Voice of Prophecy programs. G. F. Ebinger, "A Voz da Profecia na Missão Baiana,” Revista Adventista, October 1944, 10.

${ }^{30}$ It was suggested, for example, that church members should invite to Sabbath School those who had been in contact with the Adventist message through other members, literature, or Voice of Prophecy.
} 
ingathering campaign to promote the Voice of Prophecy. ${ }^{31}$ But another example became more typical of the integration between the Voice of Prophecy and the local church. In 1959, in one neighborhood of São Paulo City, lay people were trained to visit homesand sign up people interested in Bible correspondence courses. It was also their responsibility to deliver the lessons each week. After reaching a listener base of more than sixty percent of the people in that area, an evangelistic series was organized. At the beginning of each program people listened to the introduction of the radio program and the Lord's Prayer in the voice of the official speaker. This was the first time that Voice of Prophecy and public evangelism were integrated. ${ }^{32}$

\section{Spiritual Organic Systems}

The development of spiritual organic systems, an element of the Adventist movement ethos model, in connection with radio and television evangelism was gradual. The radio ministry was not embraced by South American ministers immediately. Some did not believe radio was an effective evangelistic method. It also did not excite those who had pioneered in this area, but who were not consulted when the church began its radio work. The new method did not become a miracle worker nor did it supplant the

The approach should include a Sabbath afternoon meeting at home to study the Sabbath School quarterly and to organize a branch Sabbath school. José Baracat, "Como Atrair Mais Membros Para as Nossas Escolas Sabatinas," Revista Adventista, May 1952, 5; João A. Barcelos, "Escolas Sabatinas Filiais," Revista Adventista, August 1952, 13.

31“"A Voz da Profecia,” Revista Adventista, June 1947, 32. For example, one church member, while talking to a tailor who had donated the previous year, had connected him to the radio broadcast. He had been listening to the program and was almost at the end of the lessons. He also tripled his contribution. Palmer Harder, “A Seara É Grande e Poucos os Ceifeiros,” Revista Adventista, October 1947, 22.

${ }^{32}$ Alcides Campolongo, ““A Voz da Profecia' no Estado de São Paulo,” Revista Adventista, March 1968, 20; Itanel Ferraz, "Passos que Antecedem uma Série de Conferências," Revista Adventista, September 1968, 12. 
traditional forms of evangelism, but soon almost everyone realized its evangelistic

potential. ${ }^{33}$ Most evangelists and colporteurs realized the advantages of this new method and decided to include it in their work. Because of the wide recognition of the name "Voice of Prophecy," many public evangelists advertised their meetings in connection with the radio program. ${ }^{34}$ Literature evangelists decided to help gather names of people for the correspondence courses. ${ }^{35}$ After a while, only the Catholic Church seemed to be opposed to the growing influence of the Voice of Prophecy. Through local priests and national Catholic newspapers Catholics were warned against the revolutionary message being broadcast by the Adventist cult. In the end such warnings helped create an even greater awareness of the Voice of Prophecy. ${ }^{36}$

\footnotetext{
${ }^{33}$ Greenleaf, A Land of Hope, 412, 414; Lylon H. Lindbeck, “As Primícias da 'Voz da Profecia' na América do Sul," Revista Adventista, February 1945, 4.

34“"Noticias do Escritório da Voz da Profecia," Revista Adventista, Janeiro 1945, 32. Evangelists like Campolongo linked their meetings with Voice of Prophecy and Faith for Today since those connections attracted listeners and viewers. Alcides Campolongo, Evangelismo, Minha Paixão (Tatuí, SP, Brazil: Casa Publicadora Brasileira, 2009), 85. Henry Feyerabend also found the combination between temperance and Voice of Prophecy in his evangelistic campaigns to be attractive. Ardoval Schevani, "O Binômio 'Voz da Profecia' e 'Temperança' no Evangelismo do Paraná," Revista Adventista, August 1968, 22. Arno Köhler also united evangelism and Voice of Prophecy in a plan called Colheita Rápida (Fast Reaping). Arthur S. Valle, "Manchetes da União Sul-Brasileira," Revista Adventista, November 1969, 30.

35“"Colportagem e Voz da Profecia Fazem Sucesso," Revista Adventista, September 1969, 19. The introduction of the Bible study guide A Bíblia Fala (The Bible Speaks) in 1968 was a landmark. The plan was for church members to evangelize using the 24 lesson-series. A Bible accompanied the set and was a gift to those who finished the lessons, which was an attraction. This tool, promoted by the General Conference, had questions and Bible verses to help find the answers. The use of this material by church members to teach the Bible was often connected with the fulfillment of one of Ellen White's visions. J. Ernest Edwards, "Operação 'a Bíblia Fala'," Revista Adventista, March, 1968, 4-5; Enoch de Oliveira, "O Desafio de 1968," Revista Adventista, November, 1967, 3-4.

${ }^{36}$ Oscar Castellani, "O Nordeste e a Voz da Profecia," Revista Adventista, January 1945, 6. For example, on November 19,1944, the Catholic publication with the largest distribution in the country featured the work of the Voice of Prophecy and the Adventists. While it used a cautionary tone, the description was very detailed and mentioned Adventist institutions in a way that raised curiosity in the minds of their readers. Américo R. Coelho, “A Voz da Profecia," Revista Adventista, February 1945.
} 
Besides airing radio programs, the Voice of Prophecy began to implement itinerant public evangelistic meetings by the speaker and the quartet. During 1952 and 1953 the Voice of Prophecy began to organize "lightning conference series" — short series in large cities for large audiences ${ }^{37}$ — which were reaping events that also brought new life to local churches. ${ }^{38}$

Lay members prepared communities for visits by Rabello and his team, including the quartet, Arautos do Rei, by enrolling people in the radio correspondence lessons and systematically visiting individuals who evinced an interest. Rabello's visits were, in a sense, a culminating evangelistic activity during which he awarded certificates to those who had completed the correspondence course and called for decisions to be baptized. ${ }^{39}$

About two decades after the first broadcast, there was an initiative to combine the radio and television ministries with urban evangelism. The church bought land in Rio de Janeiro, and built radio studios, offices, and an auditorium. The Bible Correspondence School was also part of that structure. ${ }^{40}$

\footnotetext{
${ }^{37}$ Roberto Rabello, "Noticias do Escritório da Voz da Profecia," Revista Adventista, September 1952, 9; Jeronimo G. Garcia, "Series de Conferencias Relâmpago," Revista Adventista, May 1955, 7. In Belém and Manaus the conferences were held at their main venues Teatro da Paz and Teatro Amazonas, which holds about 7,000 people. Roberto Rabello, "Conferências pela Voz da Profecia," Revista Adventista, February 1953, 14; Alcides Campolongo, "Grandes Concentrações da 'Voz da Profecia' e 'Fé para Hoje' no Estado de São Paulo,” Revista Adventista, July 1967.

${ }^{38}$ Waldemar Leitzke, “Movimento Que Não para Mais,” Revista Adventista, January 1958, 36.

${ }^{39}$ Greenleaf, A Land of Hope, 488 . The division took steps to help mobilize church members and voted that everyone was supposed to be involved in the distribution of fliers regarding correspondence courses by going door to door and signing people up. Their goal for each church member in 1945 was one registration per week for the correspondence school. Santiago Schmidt, "Novo, Poderoso e Indispensável," Revista Adventista, Maio 1945, 10. Listeners were given a chance to become contributing members by sending donations and receiving a book of the month as a token of appreciation. Lylon H. Lindbeck, "Membros Contribuintes e o Curso Gratuito de Bíblia," Revista Adventista, August 1945, 9.

${ }^{40}$ Besides the office in Rio, two other branch offices were opened in Brazil. In the late 1970s, another attempt to coordinate the media ministries was for each pastoral district to establish a "Voice of Prophecy Mini Branch." Contact information from interests was sent to the mini branch closest to the address in order for people to be assisted in their Bible study courses. Timm, "Building a Growing Church."
} 
The novelty of radio started to wear off and the new technology of television become more and more popular. It was only in 1991 when the first Adventist television program began airing nationally after a group of Brazilian businessmen through their recent-formed Federação dos Empresários (Businessmen's Federation) decided to finance the airing of George Vandeman's It Is Written. ${ }^{41}$

During the second half of the 1990s communication in Brazil entered the high tech age. Part of this new moment in communication was due to the many satellite evangelism programs. A new institution was created and Sistema Adventista de Comunicação (SISAC) became responsible for production of Voice of Prophecy, It Is Written, and promotion of satellite technology. SISAC also oversaw the work of 20 radio stations. The South American facility in Nova Friburgo, Rio de Janeiro, operated a growing network with new opportunities for a new generation of denominational workers. $^{42}$

\section{Community for God and Disciple-making for Eternity}

Community and disciple-making, two elements of the Adventist movement ethos, were also combined in radio and television evangelism in Brazil. The core element was the broadcast message. Testimonies of listeners indicate that they were blessed in different moments of their lives, such as with answers to doctrinal questions, existential

\footnotetext{
41،Finalmente, Um Programa Nacional de Televisão," Revista Adventista, October, 1991, 44; "Finalmente, Surge uma Boa Idéia," Revista Adventista, December, 1991, 2; "Empresários Querem Participar Mais," Revista Adventista, March, 1992, 18.

42“"Sisac Divulga Atividades,” Revista Adventista, July, 1996, 24; “Sonho Realizado,” Revista Adventista, January, 1997, 18.
} 
problems, and family issues. ${ }^{43}$ The major challenge faced by this mission method, however, was how to connect listeners with the local churches. ${ }^{44}$

The Correspondence School was the right hand of the Voice of Prophecy and had the task of cultivating the interests created by the program. ${ }^{45}$ Listeners received Bible study lessons and other types of Adventist literature, studied the lessons, answered the questions, and returned them to the school in order to receive the next lesson. In 1964 church leaders came up with the idea of a graduation ceremony for those who had finished their Bible correspondence courses.

Following the graduation ceremony it was recommended that an evangelistic series or a Bible class start the following Sunday evening at a local church with the same group. ${ }^{46}$ During this process, the excitement often became contagious where listeners who were learning about the Bible would mingle with the local congregation and begin to

\footnotetext{
${ }^{43}$ Rabello, "Uma Porta Aberta," 11; Moisés S. Nigri, "O Departamento do Rádio da Associação Paulista dos A. S. D.," Revista Adventista, January 1944. The first baptism as a direct result of the Voice of Prophecy was a young college student in Argentina. One day, after listening to the program, he requested a copy of the transcript and signed up for the correspondence course. After completing lesson 10, he decided to find out about the church behind the program. One Friday evening, while riding his bike around town, he saw a group of youth in front of an Adventist church and decided to stop and ask if they knew anything about the Voice of Prophecy. Lindbeck, "As Primícias da 'Voz da Profecia' na América do Sul," 3. In Brazil, one impressive story was about a young man who had committed a crime and was in prison. He was able to escape and in the days that followed, while hiding, he got a small battery-operated radio and connected to the Voice of Prophecy. One day, a colporteur came to his neighborhood, told him about the Adventist Church, and counseled him to turn himself in to the police and go back to jail in order to get ready for baptism. S. Bacelar de Assunção, "O Que a Voz da Profecia Pode Fazer," Revista Adventista, May 1958, 29.

${ }^{44}$ C. E. Lambeth, "Programa Que Faltava," Revista Adventista, September 1944, 11.

${ }^{45}$ Roberto Rabello, “A Escola Radiopostal,” Revista Adventista, July 1945, 5, 9.

${ }^{46}$ Campolongo, ““A Voz da Profecia' no Estado de São Paulo,” 21.
} 
instruct others. So listeners became missionaries and approached their friends and neighbors. $^{47}$

The number of people reached by this method in the first 30 years was high but even more impressive was the fact that this method was able to reach different groups of people. ${ }^{48}$ Radio proved to be democratic — it reached all social classes. It reached the rural areas where families gathered around a receiver to listen to those programs - their only spiritual nurture - and thousands were only members of the "Voice of Prophecy church." ${ }^{49}$ This mission method reached other groups of people including senators, congressmen, university professors, businessmen, wealthy landowners, doctors, clerics, and students. ${ }^{50}$

But every contact did not however have a happy ending. Since the Voice of Prophecy was not readily linked to the Adventist Church, some listeners ended up joining other evangelical churches. ${ }^{51}$ Nonetheless, at the beginning of the $1980 \mathrm{~s}$ "church leaders

\footnotetext{
${ }^{47}$ Boehm, "Ressonância da Voz da Profecia," 6. The traditional annual humanitarian campaign, Ingathering, exemplifies the numerous possibilities of radio evangelism. In 1949, while gathering donations, church members distributed the missionary magazine ( $O$ Atalaia $)$, an advertisement for Voice of Prophecy, and a special leaflet. It was considered a missionary contact. It is estimated that $95 \%$ of the people contacted in the East Union had heard about the Voice of Prophecy. R. E. Adams, "Na União EsteBrasileira," Revista Adventista, September, 1950, 4.

${ }^{48}$ Greenleaf, A Land of Hope, 414. In 1945, two years after the beginning of the Voice of Prophecy in South America, 80,000 students had been enrolled in the Bible lessons and more than 2,000 had either accepted the Sabbath truth or requested baptism. In Brazil, from 1943 to the beginning of 1963 the radio correspondence school received 401,362 requests for its course, 133,150 actually enrolled, and 30,234 completed it. During 1973 a total of 20,845 students enrolled. The Seventh-day Adventist Encyclopedia.

${ }^{49}$ Adams, "Na União Este-Brasileira," 11.

${ }^{50}$ Lindbeck, "As Primícias da 'Voz da Profecia' na América do Sul,” 3; Edgar V. Almeida, "Como Conheci a Igreja Adventista," Revista Adventista, August 1945, 23.

${ }^{51}$ Timm, "Building a Growing Church,." Castellani, "O Nordeste e a Voz da Profecia," 6. In Pernambuco, for example, a lady who belonged to a wealthy family had listened to Voice of Prophecy by
} 
estimated that 40 percent of their converts traced their membership at least partially to exposure to radio and television ministry." $" 52$

\section{Metropolitan Evangelism (1980)}

\section{Contextual Dynamics in Brazil: Redemocratization}

Part of the initiative for political openness came from within the military itself. During the Geisel government, Brazilian society witnessed an easing of censorship and police surveillance. Different segments of the population also intensified their push for democracy. Brazilian business leaders, metalworkers, and lawyers, voiced civilian opposition. The international community, especially the United States, also added pressure for change because of the country's use of torture and the abuse of human rights. The pressure from all these sources slowly eroded government authoritarianism. The Geisel presidency ended in 1979, but gave way to the fifth army general president, João Batista Figueiredo. His stiff German-like personality was succeeded by another army general who was not able to deal with the deficitary economy. ${ }^{53}$

The Catholic Church, artists, and sports personalities became actively involved in agitating for change by protesting against the abuses of the military and endorsing popular rallies that resulted in elections in 1985. The opposition's candidate and embodiment of the country's hopes, Tancredo Neves, although elected, was never inaugurated due to health complications that led to his death on the day before he was to

\footnotetext{
chance and insisted in introducing it to the rest of her family. For some time, they did not know which church produced the broadcast. Lindbeck, "As Primícias da 'Voz da Profecia' na América do Sul," 3-4.

${ }^{52}$ Greenleaf, A Land of Hope, 490.

${ }^{53}$ Skidmore, Brazil.
} 
take office. His vice-president, José Sarney, became the president during a challenging period characterized by an inflationary crisis and the rebuilding of democracy, including the drafting of a new constitution. The next decade was marked by a continuing foreign debt crisis and successive failed stabilization plans. A contributing factor was that after the 1929 crash, Brazil had concentrated on inward looking development by setting high tariff protections that discouraged foreign investments. This resulted in a brain drain, as the best and brightest left Brazil, widening the gaps between rich and poor, causing a deterioration of education, health care, housing, roads, and communication systems. As part of the maturing of the democracy in Brazil, the country witnessed the creation of new political parties, the impeachment of a president in 1992, and the government of another vice-president until it began to find ways to implement economic stabilization in 1994. The two terms of Fernando Henrique Cardoso's government consolidated the economic stabilization through tariffs reduction, new deficit spending levels, and privatization of state enterprises. During this time, women began to play a larger role in Brazilian society and steps were taken toward racial equality, while artists and intellectuals that had protested strongly against the military government, became more passive. $^{54}$

Contextual Dynamics in the Church: Consolidating Growth Church leaders were responsible for keeping church operations afloat despite the instability in both the political and economic environments. The church was also

\footnotetext{
${ }^{54}$ Skidmore, Brazil, 185-228.
} 
impacted by the idealistic goals of democracy, equality, and liberation that were part of the Brazilian social climate. ${ }^{55}$

By the end of the 1970s missionary fervor had reached a high point in the South American Division as a "result of a coordinated effort involving not just public evangelism but literature distribution, radio and television programs, correspondence lessons, and 'the most important of all,' participation by the lay membership who had visited 5,000,000 homes and given away 10,000,000 pieces of literature" ${ }^{, 56}$ in 1979 alone. Despite reaching membership milestones during this period, the population and cities were growing at even higher rates than the church's membership. ${ }^{57}$

\section{Mission Method}

In 1981 Neal Wilson, General Conference president, launched a new evangelistic campaign with a goal of a million baptisms by 1985 under the theme "One Thousand Days of Reaping.” John Wolff, South American Division president, had adopted the motto "Sowing, Reaping, and Keeping" in 1980. With a specific emphasis on the involvement by local congregations, Wolff encouraged ministers to mobilize all resources (money, people, institutions, and plans) to conduct "intensive metropolitan evangelism," 58 which became the "signature method" of the division and a new wave of

\footnotetext{
${ }^{55}$ Enoch de Oliveira, "The Lord at Work," Adventist Review, April 27, 1980.

${ }^{56}$ Greenleaf, A Land of Hope, 611. The division reached record levels of baptism in 1979.

${ }^{57}$ João Wolff, “A Story of Gratitude and Praise,” Adventist Review, July 11, 1990, 22-24.

${ }^{58}$ Wolff, “The Lord Has Done Great Things for Us," 16.
} 
mission in Brazil. ${ }^{59}$ It was "a coordinated plan aimed at urban centers . . but metropolitan evangelism also meant harnessing the energy of individuals and congregations for soul-winning purposes as much as it presupposed preaching to large audiences. $" 60$

A typical metropolitan campaign was the Campolongo's evangelistic meetings in 1983 in the state of São Paulo. In that urban setting a team of workers helped at 12 separate sites. Each speaker preached at two places on alternating nights. The project lasted seven months and had 1300 baptisms. ${ }^{61}$ Besides the involvement and baptisms, some pastors reported the mass conversions of entire congregations, including pastors. In some cases, properties were transferred to the Adventist Church. ${ }^{62}$

For the 1985-1990 period the General Conference promoted the "Harvest 90" program and a similar pattern of growth from the previous five years continued in the South American Division. During this time the emphasis progressed from metropolitan campaigns to national programs and a continental view of spreading the gospel under the motto "Sowing, Reaping, and Keeping." 63 Metropolitan evangelism was described as "the throb of soul winning activity."64

\footnotetext{
${ }^{59}$ Greenleaf, A Land of Hope, 612.

${ }^{60}$ Ibid., 631.

${ }^{61}$ Campolongo, Evangelismo, Minha Paixão, 163-164; Wolff, “The Lord Has Done Great Things for Us," $16-18$.

${ }^{62}$ Greenleaf, A Land of Hope, 610.

${ }^{63}$ Ibid., 613.

${ }^{64}$ Lowell Bock, "Visitor Sees Soul-Winning Activity in South America," Adventist Review, March 25, 1982, 16-17; "News Note," Adventist Review, May 2, 1985, 20. "For the Record," Adventist Review, March 8, 1984, 23. At the end of 1985, the division celebrated 309,000 baptisms for the 5-year period. At
} 
During the second half of the 1980s and 1990s, Alejandro Bullón, a Peruvian, who worked in Brazil, was responsible for a new wave within metropolitan evangelism. In 1986, he organized a large youth congress, like a pathfinder camporee, for more than 10,000 people from more than 150 locations in Brazil. The camping area was referred to as Adventist Youth City with space for three thousand tents. ${ }^{65}$ The youth served the local community through blood donations, distribution of clothing, visitation, distribution of 5,000 magazines, a march against tobacco and alcohol, and other missionary actions. Three large evangelistic series were conducted in the host city and 13 other smaller preaching series happened with 200 people baptized. The bigger difficulty was the high cost. At the time, Bullón pointed out that the congress should not be an end in itself but an instrument to strengthen youth societies in order for them to witness. ${ }^{66}$

\section{Jesus: Lord, Savior, and Priest}

The message of metropolitan evangelism was primarily focused on Adventist doctrines and prophecy, an indication of the first element of the Adventist movement ethos model. Bullón, however, introduced a new emphasis on establishing a relationship with Jesus as everyone's friend. ${ }^{67}$ He believed preaching was too theoretical, impersonal, and formal in presenting spiritual issues. His goal was to help people establish a real,

the end of 1990 the division overcame the 1-million-member barrier and Brazil had the largest number of Adventists.

65“"Itabuna em Mira,” Revista Adventista, March, 1986, 30.

66“CCampal Reúne Dez Mil Jovens,” Revista Adventista, August, 1996, 20-21.

67“Amigos Para Sempre,” Revista Adventista, May, 1985, 30. Bullón believed Christ should be presented not as a judge looking for people's faults, but as a friend who loved people to the point of giving His life for them. "Como Lidar Com Os Jovens," Revista Adventista, June, 1987, 9. 
practical, and informal relationship with God through Bible study and prayer. He believed that the church's focus was to introduce norms of faith when, in reality, the young people needed people to teach them how to put their faith into practice. ${ }^{68}$ Jovens," 9-10.

68“"Renovação Espiritual,” Revista Adventista, November, 1986, 36. "Como Lidar Com Os 


\section{Missional-Incarnational Impulse of the Coming of Jesus}

Missional-incarnational impulse, another element of the Adventist movement ethos model, took new forms especially in late 1980s and early 1990s in addition to the initiatives of multi-location metropolitan evangelism. Church leaders came to realize the unevenness of church growth in the 1970s and early 1980s when membership increased primarily in regions where the church was already strong. ${ }^{69}$

A broadening of missionary focus was the result of several initiatives. A contextualized outreach strategy introduced during this time was related to the Day of the Deceased, the official holiday to honor dead relatives in Brazil.

Instead of inviting the public to a powerful sermon that would set the record straight about the biblical teaching concerning death, many Adventist youth frequented cemeteries on the Day of the Deceased, empathizing with sorrowing families, singing hymns, and offering hope and comfort. In the process they also distributed appropriate literature. Such reassurance did not guarantee converts, but in a culturally compatible manner, it extended Christlike, sympathetic support and planted seeds that would generate inquiry. ${ }^{70}$

Another initiative was a unique project that resulted from a division study. In the early 1970s, Roberto Azevedo, a biology teacher at Brazil College, conducted research on Brazilian communities with more than 10,000 people. He pointed out that the high baptismal figures did not give a complete picture of reality since the Adventist Church had not been focusing on unentered municipalities. He believed that the church would

\footnotetext{
${ }^{69}$ Greenleaf, A Land of Hope, 615. Division president Wolff admitted that Global Mission had forced church leaders to stop and analyze which places remained unevangelized and make a plan to change that situation. João Wolff, “A Blazing Continent,” Adventist Review, July 1995, 10.

${ }^{70}$ Wolff, "The Lord Has Done Great Things for Us."
} 
need more than sixty years before it had covered Brazil. ${ }^{71}$ In 1990 the General

Conference unveiled Global Mission and the strategy to plant a new church in every one of the unreached 1,800 people-groups by $2000 .^{72}$

During the 1990s, following Harvest 90 and the Global Mission initiatives, new developments also took place in Brazil, including new conferences and union offices in newly-entered territories, mostly in the North and the Northeast. ${ }^{73}$ Eventually, this new emphasis on church development based on geographic expansion was applied to municipalities. Despite these new strategies, in 1995 challenges remained. Growth was uneven. On the one hand, a 1996 report pointed out that only seven municipalities in the territory of the South Mato Grosso Conference remained without an Adventist presence. ${ }^{74}$ On the other hand, Azevedo's evaluations pointed to many towns still with no Adventist presence. ${ }^{75}$ In 2000, Ruy Nagel, division president, acknowledged the unentered territories. $^{76}$

71“Difusão: Após 10 Anos," Revista Adventista, May, 1985. Roberto Azevedo became the education departmental director for South Brazil Union during the second half of the 1970s and had the same job at the division during the 1990s.

${ }^{72}$ Neal Wilson, “Global Mission: Person to Person,” Adventist Review, July 5, 1990.

73“"Crescimento e Desafios," Revista Adventista, November, 1981. In 1990, the first conference was organized in the North Brazil Union. One of the fields had organized in 1927 and had taken a long time to become self-sustaining. "Missão Amazônia Ocidental Torna-Se Associação," Revista Adventista, February, 1991, 23.

74““Assembleia Mostra Crescimento na Uniao Sul,” Revista Adventista, April, 1996.

${ }^{75}$ Roberto C. Azevedo, “Missão Global 2000,” Revista Adventista, March, 1995.

${ }^{76}$ Nagel, "Our People on the March." Ruy Nagel, "From Small Beginnings, a Bountiful Harvest," Adventist Review, July 62005 . The church identified "conquered" towns as those with a rate of 1 member to 500 inhabitants; "entered" municipalites had less than 1 member to 500 inhabitatns; and "zero" municipalities had no Adventists. 


\section{Apostolic Environment within the Great Controversy}

The excitement during the One Thousand Days of Reaping translated into large gatherings. In 1983, for example, a youth congress gathered six thousand people in Espirito Santo. Young people traveled by bus, train, car, and bicycle to participate in this event. The youth department director in charge of this congress was Bullón. This was one of the first large gatherings that he organized. ${ }^{77}$

Voice of Prophecy speakers had already experimented with large audience evangelism but they did not envision their meetings as reaping events, as did Bullón. Lay people, especially youth, would engage with their friends in studying the Bible and take them to those meetings. In 1984, for example, leadership training for young people took place in Rio de Janeiro for the One Thousand Days of Reaping. Bullón promoted Project 1+1=Friendship and a Voice of Prophecy Bible study guide (Encontro com a Vida). The goal was for each person to study the Bible with three others in order to prepare for the metropolitan evangelistic meetings that would take place later that year. ${ }^{78}$ This strong emphasis on personal evangelism is easily observed in Bullón's articles. ${ }^{79}$

77،"Participação Jovem Nos 'Mil Dias de Colheita'," Revista Adventista, December, 1983, 21. The first campmeeting of the Northeast Mission in 1984 gathered 3,000 people, mostly youth, for four days. “Como Nos Dias de Israel," Revista Adventista, June, 1984, 18.

78“"Rumo À Luta,” Revista Adventista, July, 1984, 31.

79،"People change people" was the title of a magazine article in which he invited church members to mobilize in prayer to plant new churches and to give Bible studies. Alejandro Bullon, "Gente Muda Gente," Revista Adventista, March, 1991, 8-9. In another article, he mentions people on fire for the gospel; people who spare no effort to talk about Jesus to other people. The joy of witnessing, according to him, is that "every time a church member shares his or her faith with others, his or her desire to seek Jesus increases.” Alejandro Bullon, “A Alegria de Testemunhar," Revista Adventista, June, 1991, 10. 
Bullón challenged church members to get involved in personal witnessing ${ }^{80}$ but he also became involved in Global Mission while division evangelist, emphasizing the need to enter new areas in South America. ${ }^{81}$ Although Bullón's main efforts were directed toward preaching to large audiences, he developed a visionary understanding for global mission.

Global mission is more than baptizing. One can break all the records of baptisms from previous years fulfilling the mission. But this does not necessarily mean the fulfilling of the mission in a global way. Global mission makes us leave our routines and establish priorities. Not to slow down our work, but to redirect it in such a way that we can set the flag of the gospel in geographic territories and in people groups where no one has worked before. ${ }^{82}$

\section{Spiritual Organic Systems}

In metropolitan evangelism, spiritual organic systems, an element of the Adventist movement ethos model, developed in relation to General Conference evangelistic initiatives and the South American Division evangelist. The "Sowing, Reaping, and Keeping” of early 1980s had specific emphasis on involvement by local congregations. While members were in charge of sowing, ministers took care of reaping. Two years later “The Thousand Days Campaign” was launched to capitalize on Holy Week "as an

\footnotetext{
${ }^{80}$ One of the primary objectives of Project Sol was to inspire young people to witness of their faith. Alejandro Bullon, "O Sol da Aurora Eterna Já Desponta no Horizonte," Revista Adventista, December, 1990, 9; "Propaganda e Testemunho," Revista Adventista, June, 1988, 18; "Como Lidar com os Jovens," 8.

${ }^{81}$ Project Abraham, for example, tried to find 100 families who would move to towns with no Adventist presence. Project Adopt a City tried to find Sabbath School classes, AY societies, Pathfinder clubs, and Adventist institutions that would adopt a town and take on the challenge to establish a congregation. Alejandro Bullon, "Sai da Tua Terra..." Revista Adventista, November, 1991, 47. Project Pioneer suggested that a group of 15 to 20 members of a large church or a Sabbath School class choose a location (other than the church) to conduct evangelistic meetings during Holy Week. The small groups were encouraged to follow up their meetings with Sabbath services as a church planting project. Wolff, "A Blazing Continent."

${ }^{82}$ Alejandro Bullon, “Missão ou Missão Global?” Revista Adventista, December, 1992, 41.
} 
opportune moment to organize evangelism as a key strategy for much activity." 83

Metropolitan evangelism continued to be the main type of evangelism with multiple-

location campaigns. There were meetings conducted by pastors and evangelists, and smaller ones where lay leaders preached. ${ }^{84}$

Toward the end of the 1980s the success of the large youth congress that Bullón organized in 1986 became the base for the large-audience revival and evangelism events in sports venues and stadiums. The first of such events took place in 1988 in São Paulo at Ibirapuera Arena for more than 30,000 people and was called Project SOL, which stood for Week of Prayer and Praise in Portuguese. In preparation for that event, a large support system was created with a strong emphasis on professionalism and quality. ${ }^{85}$ In summary, Project SOL, according to Bullón, was a mix of personal and public evangelism. ${ }^{86}$ Bullón organized those types of events for two decades in many cities of Brazil. Sometimes the gatherings lasted for a week, sometimes only for a weekend. ${ }^{87}$ In 1994, Bullón was

\footnotetext{
${ }^{83}$ Greenleaf, A Land of Hope, 609.

84،"Evangelismo Acelerado," Revista Adventista, May, 1985, 30.

85“Programação no Ibirapuera Será 'Espetacular mas Não Show',’ Revista Adventista, June, 1988,
} 21. The support system included professional sound system, 15 days of advertisement on three TV stations, 260 outdoor ads, t-shirts, and stickers. Every evening the program consisted of a music concert for 20 minutes, congregational singing for 20 minutes, prayer for 5 minutes, and preaching for 50 minutes. Pastor Alejandro Bullón partnered with Williams Costa Junior, an experienced church musician, and his wife Sonete Costa, an Adventist recording-artist, for the initial 40 minutes. Next, a pastor would pray for parents, for authorities, for the poor, for the unemployed, and for the sick. On each of the eight evenings the message was focused on Jesus as the answer to everyone's problems followed by an appeal to accept Him as Lord and Savior. Altar calls were a high point of Bullón's evangelism since he believed that people would respond more promptly in an environment full of people who would motivate each other.

86“Pastor Bullón Explica Projeto Sol,” Revista Adventista, April, 1988, 20.

${ }^{87}$ Timm, "Building a Growing Church," This pattern was followed in smaller scale. "Campal Reúne 3.500 Jovens na Cidade de Bauru," Revista Adventista, August, 1988; "Eventos Movimentam a Igreja em Mato Grosso," Revista Adventista, August, 1988, 25; “Congressão Leva a Ipatinga Mais de 2 Mil Jovens," Revista Adventista, August, 1988, 26; "Semana de Oração e Louvor Reúne Mais de Três Mil Jovens," Revista Adventista, August, 1988, 33; Robson Marinho, "Sol-Leste Gera Classes Bíblicas e 
appointed as the new speaker for It Is Written in Brazil as George Vandeman retired. At this point two decisions were made: the television program would clearly state that it was produced by the Adventist Church and Bullón's evangelistic meetings would be linked to the program. By that time, It Is Written had wide reach (95\% of Brazilian municipalities) and a solid presence among religious broadcasts in Brazil (most watched). ${ }^{88}$ In the following years, other similar events for large audiences were organized by different evangelists. $^{89}$

Metropolitan evangelism was a coordinated effort that, ideally, involved more than congregations. Institutions and all church departments were expected to be a part of the missionary effort. However, the country's economic instability had a strong effect on the missionary contribution by Adventist institutions during this time. ${ }^{90}$

In 1985 the number of beds in Adventist health care institutions reached its highest point (1,481 beds in the division), but things changed during the next 20 years. Adventist hospitals gave added publicity to the church in Brazil. They were used as sets for television productions, were the preferred health care providers for the wealthy, and

Batismos," Revista Adventista, January, 1990, 23; “Encontro Sorriso Reúne Sete Mil no Tarumã,” Revista Adventista, January, 1990, 31; “Projeto Revive Repete Êxito,” Revista Adventista, January, 1993, 15.

88،"Um Ministério de Fé," Revista Adventista, June, 1992, 19. "Está Escrito," Revista Adventista, November, 1993, 22. "Está Escrito," Revista Adventista, May, 1994, 23.

${ }^{89}$ In 1999, Mark Finley preached for nine days in São Paulo at the Brazil Adventist University (UNASP) church. Acts 2000 meetings were broadcast via satellite to many churches with an estimated 200,000 people attending that event. This was supposed to be a reaping event to follow up preparations made by lay members throughout the country. In 2000, Henry Feyerabend and Joel Sarli conducted Hope 2000 from the Vila Formosa church in São Paulo. Their meetings on Adventist doctrines were broadcast via satellite to the churches with approximately 300,000 people attending. "Acts 2000 Impacts Brazil," Adventist Review, September, 1999.

${ }^{90}$ Greenleaf, A Land of Hope, 631. 
pioneered in specific areas. However, several new ventures did not last more than a decade. For example, Belo Horizonte Adventist Hospital with 250 beds had to be returned to Golden Cross in 1986 after financial problems. Since then the strategy for health care has changed from expansion to consolidation. New denominational initiatives concentrated on small clinics and heath care centers. The emphasis shifted to promotion of a healthy lifestyle and natural remedies. ${ }^{91}$

By 1980, Superbom, the health food manufacturer, was experiencing financial pressures. Starting in 1973, it established a chain of vegetarian restaurants as a way of introducing Adventism through the message of diet reform to the general public. That did not take off and the restaurants closed during the latter half of that decade due to unfavorable economic conditions. The limited contribution of Superbom to the image of the church came through the sale of high quality products like fruit juice, jam, cereal, and honey that helped the church to present itself as a contributor to public health. ${ }^{92}$

The Adventist river launch ministry, that had come to symbolize the social conscience of the church, also grew between 1960 and 1980 as it extended medical assistance to inhabitants of riverine lands and brought the gospel to unreached tribes and communities. However, in the 1980s that ministry slowly disappeared due to new

\footnotetext{
${ }^{91}$ In the 1940s two hospitals began in Brazil, Rio de Janeiro and São Paulo. Until the 1980s new health-care institutions were created that varied from small clinics to over 100-bed hospitals. By 2004 the number of beds in the division was below 1,000. Greenleaf, A Land of Hope, 647-649. Pênfigo Adventist Hospital, near Campo Grande, founded in 1951 developed a unique treatment for savage fire and served many people using outside funding. This important venture received special media attention in 1982. “Construction at 'Savage Fire' Hospital," Adventist Review, January 14, 1982, 21.

92“'South American," Adventist Review, November 28, 1985. Superbom began in 1925 and had highs and lows until 1970s.
} 
government regulations concerning medical services and decreased financial support from the church. ${ }^{93}$

In the mid-1980s the Brazil Publishing House made a major move away from São Paulo City in order to expand on low cost commercial land, to ease transportation issues, avoid pollution, and lower the cost of living for its workers. Around the same time, the publishing house had to deal with another major shift: a change in the nature of colporteuring in Brazil. Between 1980 and 2000, the number of literature evangelists was in decline. By 2007, fewer colporteurs in the South American Division held credentials as literature evangelists than in 1930, a clear indication that things had changed. Colporteuring had shifted its emphasis to seasonal student colporteurs. Greenleaf suggests that this scenario probably "reflected the fact that door-to-door sales in many consumer-oriented societies was an outmoded technique."94

Denominational schools also offered a mixed scenario. While enrollment had grown until the mid-1990s (the record was 111,000 students in 1995), it was noted that between 1976 and 1983, Adventist congregations were not establishing schools to match membership increases. That had serious consequences for the retention of young members. ${ }^{95}$ In the mid 1950 s, "no one thought of a church without also thinking of a school. It was an inseparable pair." Evangelists had a goal of erecting a sanctuary and a

\footnotetext{
${ }^{93}$ Ana Paula Ramos, Desafio Nas Águas (Tatuí, SP, Brazil: Casa Publicadora Brasileira, 2009), 108-123. Leo Haliwell started in 1931 his maiden voyage on the Amazon in his river launch ministry.

${ }^{94}$ Greenleaf, A Land of Hope, 674. Osvaldino Bonfim, “Colportagem Comemora 100 Anos na América do Sul," Revista Adventista, April, 1992, 8; "Brasil Lidera Colportagem Mundial," Revista Adventista, May, 1996, 15; Jael Enéas, “A Semente Germinou,” Revista Adventista, May, 2003, 19.

${ }^{95}$ Greenleaf, A Land of Hope, 677; Roberto C. Azevedo, "Panorama Educacional da Divisão SulAmericana," Revista Adventista, February, 1992, 38-40.
} 
school. ${ }^{96}$ Statistics by Azevedo showed that beginning in 1970 two factors affected that pattern: government regulations that primary schools needed to have their own building and offer all eight primary years. ${ }^{97}$

\section{Community for God and Disciple-making for Eternity}

In metropolitan evangelism, disciple-making as a combination of personal and public evangelism started before the evangelistic meetings and fostered a sense of community. Personal Bible studies and Bible classes were part of the pre-evangelism strategy ${ }^{98}$ Disciple-making initiatives also took place after the meetings, such as followup meetings for those who had attended Bullón's series. ${ }^{99}$

Bullón also believed, as implied before, that the involvement of church youth in the process of disciple-making worked as a retention plan. He felt that weeks of prayer, for him, were one of the best methods to reduce apostasy and he also understood that young people "abandoned the world with its many attraction to serve Christ, but they are still young, dynamic, full of life. They like light, color, festivals, meetings.” The church

\footnotetext{
${ }^{96}$ Campolongo, Evangelismo, Minha Paixão, 45.

${ }^{97}$ Werner Vyhmeister, “A Problem We Dare Not Ignore--1,” Adventist Review, November 5, 1981, 6; A Educação Adventista no Brasil, 113-114.

${ }^{98}$ In preparation for Bullón's first big event, in 1986, for example, church youth were supposed to accomplish four things: (1) establish friendship with a non-Adventist young person, (2) celebrate a Friday evening vespers at the Adventist' home with his or her friend, (3) give Bible study guides on Revelation their friend, and (4) attend a special program for young people at an Adventist church on a Sabbath. "Pastor Bullón Explica Projeto Sol," 20. "Projeto Sol Visa a Não-Adventistas," Revista Adventista, March, 1988, 20; "Programação no Ibirapuera Será 'Espetacular mas Não Show,'” 20-21.

${ }^{99}$ His evangelistic meetings were also recorded and made available in VHS tapes. Marinho, "SolLeste Gera Classes Bíblicas e Batismos," 23; “Congresso Reúne 5.000 Jovens," Revista Adventista, January, 1990, 29.
} 
offered recreation, social meetings, and camps in order to help them transition, but those activities often did not help them develop a personal relationship with Christ. ${ }^{100}$

Youth congresses and camporees were part of the church initiatives aimed at helping young people develop a genuine Christianity by involving them in blood drives, community projects, planting trees, cleaning up beaches, and other environmental projects, and copying the Bible by hand. Young people were also encouraged to spend their vacations as volunteers on mission launches, working in hospitals, clinics, schools, or churches. ${ }^{101}$

\section{Integrated Evangelism (1999)}

\section{Contextual Dynamics in Brazil: Economic Stabilization}

During the second half of the second term of Cardoso's government Brazil witnessed the growth of the opposition led by the Worker's Party and its leader Luís Inácio "Lula" da Silva. While Cardoso had been successful in reaching his goal of economic and political stability, he had not been able to achieve economic growth. The Argentine financial collapse, battles against inflation, international debt, lack of substantial foreign investment, and lack of a better articulated succession drained the energy from his presidency.

\footnotetext{
${ }^{100}$ Bullon, "A Alegria de Testemunhar," 10; "União Central," Revista Adventista, April, 1988, 24; Bullon, "A Alegria de Testemunhar," 10.

${ }^{101}$ Assad Bechara, "Youth Enjoy Prisma Service," Adventist Review, October 20, 1983, 22; Leo Ranzolin, "22,000 Youth Gather in Sao Paulo," Adventist Review, December 20, 1982, 21; "Brazil: AntiDrug Campaign Mobilizes More Than 500 Youth," Adventist News Network, accessed November 2, 2014, http://news.adventist.org/en/ all-news/news/go/1998-08-31/brazil-anti-drug-campaign-mobilizes-morethan-500-youth/; Ray Dabrowski, "Brazilian Youth Write out Three-Kilometer-Long Bible in 25 Minutes," Adventist Review, February 2000; Francisco Lemos, "50 Anos de História," Revista Adventista, April, 2000, 6-8.
} 
In 2002, Lula won the presidency after losing in three earlier attempts. He was born in poverty in rural northwestern Pernambuco and grew up in the outskirts of São Paulo. As a metalworker he had become active in the union and led strikes between 1978 and 1980. After being arrested and discharged, Lula continued an active political life as a leftist socialist. By 2002, he had been able to gather support from the masses who believed he would be able to eradicate poverty in Brazil. As Skidmore points out, for better or for worse, Lula's election was “Brazil's most important political event since the military takeover in 1964."102

The rhetoric of Lula's campaign did not become reality when he was in power. His economic team followed many of the previous government's monetary policies. Furthermore, Brazil benefited from a worldwide rise in commodity prices, rising exports, increasing oil production, and more foreign investors. In a snowball effect, this led to economic growth, higher employment rates, and a more favorable commercial balance. A dark side of government was revealed in mid-2005. That is when the first signs of widespread corruption within the government involving Worker's Party leaders was revealed. Despite the corruption scandal, the opposition had little success against Lula as he sought reelection in 2006. The lower classes were beginning to have hope for upward mobility due in part to social welfare initiatives, which were only possible because of the conservative economic policy Lula inherited from Cardoso. ${ }^{103}$

\footnotetext{
${ }^{102}$ Skidmore, Brazil, 235.

${ }^{103}$ Ibid., 235-245.
} 
Contextual Dynamics in the Church: Seeking Integration

Since the early 1980s through the 1990s, João Wolff, division president, had demonstrated his intentions to include institutions in his mission plans. Minor initiatives had been accomplished such as hiring chaplains and involving theology students in evangelistic meetings. ${ }^{104}$ Nonetheless, those were only the seeds of what was comingfor integrated evangelism was in the making.

Around the turn of the century, when Brazil's economy showed signs of stability and growth, division leaders officially began a program called integrated evangelism. Ruy Nagel, division president, believed those two words summarized their working philosophy. "The time is over when church departments are only concerned with the topics of their areas."105

\section{Mission Method}

Integrated evangelism, the fifth wave, was an attempt to include the different strategies already introduced and still ongoing in one single unified method. This method included administrators, department directors, institutional workers, local pastors, and church members. The division's idea was that all departments should work for church growth and the preservation of members. ${ }^{106}$ This mobilization was scheduled to start in

\footnotetext{
${ }^{104}$ Wolff, "A Story of Gratitude and Praise”; Greenleaf, A Land of Hope, 646.

${ }^{105}$ Nagel, "From Small Beginnings, a Bountiful Harvest." "South American Church Leaders Call for 'Massive Participation' in Evangelism," Adventist News Network, May 8, 2001.

106“Evangelismo Integrado,” Revista Adventista, July 1999, 28; Greenleaf, A Land of Hope, 632.
} 
July 1999 with training and end the first week of October with reaping evangelistic meetings. This cycle was to be repeated in the first semester of $2000 .{ }^{107}$

Initially the primary tool in this effort was the 12-lesson Interactive Bible Survey Course. This series of lessons would be used by It Is Written, made available on the internet, added to the magazine Signs of the Times, and offered at hospitals, clinics, and school. At the local church level, members were encouraged to find people interested in studying the Bible and were to use the same Bible course individually or in small groups. Those who responded to radio and TV offers would have their contact information forwarded to the nearest church. ${ }^{108}$

\section{Missional-Incarnational Impulse of the Coming of Jesus}

The missional-incarnational impulse, an element of the Adventist movement ethos model, during this period was embedded in the division program. A few other smallerscale projects were attempted. For example, in April 2000 the missionary magazine, Signs of the Times, was challenged with the objective of reaching out to government authorities, community leaders, and professionals. The nationwide promotion suggested that each church should collect a special offering on a specific Sabbath to purchase subscriptions of the missionary magazine. The local coordinator of this campaign was

\footnotetext{
${ }^{107}$ Ruy Nagel, "Gotas da Chuva Serôdia," Revista Adventista, March, 2000, 3-4; "Evangelismo 2000," Revista Adventista, December, 1999, 18.

108“"Evangelismo Integrado,” Revista Adventista, July, 1999, 28.
} 
also encouraged to collect addresses of people who were not easily accessible or could not be reached in other ways. ${ }^{109}$

This initiative ended up having a much broader meaning in the long run.

Literature evangelism was beginning to take on a prominent role in the mix of mission methods. Besides the magazine subscriptions, division leaders suggested book

109“"Projeto Missionário ‘Sinais dos Tempos,”” Revista Adventista, April, 2000, 30. 
distribution to neighbors, coworkers, family members, and former church members. They also recommended that church members work closely with colporteurs. ${ }^{110}$

\section{Apostolic Environment within the Great Controversy}

In integrated evangelism, an apostolic environment was connected with the division's push for cell groups. Small Groups was the innovation adopted and promoted by the division during integrated evangelism. An apostolic environment was fostered through this new emphasis on small cell groups led by lay members and pastors that gathered on a weekday to study the Bible and pray with friends. These groups often became the beginning of a new congregation. The concept of small groups was not new, since small, personal, and relational groups were present in previous initiatives connected with evangelistic series and Sabbath Schools. However, between 1995 and 2005, small groups became a major emphasis of the division, although, this concept was more popular in the Northeast region. ${ }^{111}$

\section{Jesus: Lord, Savior, and Priest and Spiritual Organic Systems}

The discussion about the distinctive Adventist message in integrated evangelism is connected to the spiritual organic systems, two elements of the Adventist movement ethos model. Bullón continued as division evangelist during the integrated evangelism

\footnotetext{
${ }^{110}$ Osmar Reis and Almir Marroni, "O Ministério de Publicações e o Evangelismo Integrado," Revista Adventista, September, 2001, 8-9; Ruy Nagel, "Obra de Semeadura," Revista Adventista, September, 2001, 3-4. $11,2003$.

111“South America: Church Grows Via Bible Study Groups,” Adventist News Network, November
} 
period. Although Project SOL was not as frequent anymore, the emphasis was still the same. During this period, one of the programs developed was Caravans of Hope. Evangelists followed an itinerary with short stops at several cities for preaching a message on making a decision for Christ. Although Caravans of Hope were more successful in Peru and Chile, they also traveled through parts of Brazil. ${ }^{112}$

The most obvious characteristic of integrated evangelism, however, was its organizational development. An important element was the emphasis on the role of institutions. During this period several institutions reached their high point like the Adventist School System, Novo Tempo, and the Brazil Publishing House.

The enrollment in denominational schools in 2006 exceeded 100,000 students. However, total enrollment figures do not indicate that schools were not being built for the new churches being planted and that for every seven students only one of them was an Adventists.

The Brazil Publishing House, in 2006, reported the highest sales in the Adventist world. Favorable factors included the captive audience of the large Adventist community in Brazil, modernization of sales through online seasonal events, a diverse portfolio of

\footnotetext{
${ }^{112}$ Marcio Dias Guarda, "The Caravan of Power Yields Pentecostal Results," Ministry, March, 2004; "Peru: More Than 30,000 Respond to 'Caravan of Hope,"” Adventist News Network, accesed November 2, 2014, http://news.adventist.org/all-news/news/go/2005-06-06/peru-more-than-30000respond-to-caravan-of-hope/. Heron Santan, "Itinerário da Fé," Revista Adventista, November, 2005, 25. This was a reaping event for those who had been prepared previously, sometimes through small groups. Bullón became the main evangelist for those efforts. Mark Finley and Robert Costa, speakers of It Is Written in English and in Spanish, also participated. Nancy Costa and Michele Stotz, "Caravan of Hope in Peru," Adventist Review (World Edition), October, 2005.
} 
publication including Bibles and textbooks, and the partnering with the division in major book distributions. ${ }^{113}$

During the same time that satellite evangelism initiatives started in the United States, such as Net '98, the same method was implemented in Brazil. In April 2000, a Holy Week satellite series by Alejandro Bullón, speaker of It Is Written in Portuguese, reached 3,500 sites and an estimated 350,000 viewers. In April 2001 the old correspondence school entered the age of Internet. Interactive Bible studies were made available online (www .bibliaonline.net). A network of professionals and volunteers helped with instruction, visitation, prayer, and counseling for those who wanted to learn more about the Adventist message. ${ }^{114}$

In 2006 those new demands led the church to move media operations to a new center in Jacareí, São Paulo. The new institution had 140 employees to coordinate radio and television programming as well as internet evangelistic initiatives, including the traditional It Is Written and Voice of Prophecy and the correspondence school. ${ }^{115}$

\footnotetext{
${ }^{113}$ Part of this was the growth of the Adventist school system and its demand for Adventist textbooks. In 1976 and 1977 South American Division began to write its own textbooks and stopped translating American authors. In 1982 the first copies were published. In 2000 that represented 39 percent of sales of the publishing house. By the end of 2003, Brazil Publishing House had published 12 million textbooks. Ivacy de Oliveira, "História Dos Livros Didáticos Adventistas no Brasil," in A Educação Adventista no Brasil, 113-114; Carlos Medley, "Adventist Publishing Moving in New Directions," Review and Herald, April 23, 1987, 8-10.

${ }^{114}$ Joel Sarli and Henry Feyerabend also conducted satellite evangelism in 2000 reaching large audiences through churches equipped with satellite technology. Jael Enéas, "Vitrine Evangelística," Revista Adventista, July, 2002, 28.

115“Brazil: Adventist Television Dramatically Expands under New License," Adventist News Network, accessed November 2, 2014, http://news.adventist.org/all-news/news/go/2006-04-23/braziladventist-television-dramatically-expands-under-new-license/; Jobson Dornelles Santos, "Uso da Internet na Evangelização Adventista no Brasil," Latin American Theological Seminary (Centro Universitário Adventista de São Paulo, Campus Engenheiro Coelho, 2009); Erlo Braun, "Criado o Sistema Adventista de Comunicação," Revista Adventista, March, 1996, 4-5; Williams Costa Jr., "Está Escrito: 10 Anos no
} 


\section{Community for God and Disciple-making for Eternity}

Community for God and Disciple-making for eternity, two elements of the Adventist movement ethos model, were once again connected in integrated evangelism. This mission method was focused on concentrating efforts but church leaders also connected the issue of the unity of the church with its mission. Although the original plan relied primarily on the Interactive Bible Survey Course and its follow up as far as disciple-making, ${ }^{116}$ one of the main dynamics promoted by the division between 2000 and 2005 was small groups. They believed that if church members were encouraged to have small meetings during the week, the problem of dropouts could be reduced (dropouts were more than 25\%). ${ }^{117}$ Alejandro Bullón was one of those who believed that small groups could help foster nurture and spiritual companionship, a lack of which he believed were the primary causes of apostasy.

The concept of small groups was not new. ${ }^{118}$ Through intensive training for pastors and church leaders, the concept was popularized and small, personal, relational groups became a movement in some parts of Brazil. ${ }^{119}$ In 2003 Brazil reported more than

Brasil," Revista Adventista, November, 2001, 10-12; "Está Escrito Makes a Breakthrough in Central and South America," Adventist Review, June 11, 1998.

116“"Evangelismo Integrado,” Revista Adventista, July, 1999, 28

117“'Líderes do Continente Sul-Americano Têm Encontro no Chile,” Revista Adventista, January, 1988, 18-20; Greenleaf, A Land of Hope, 634.

${ }^{118}$ In 1987, for example, 40 small meetings were held in Maranhão in preparation for a large evangelistic series. In 1998, Osmar Reis, responsible for a major push during this period, talked about three types of small groups: permanent (individuals meeting weekly to study the Bible), evangelistic (groups established during an evangelistic series), and family-on-family (groups of families gathering for Bible study). "Ministério Pessoal," Revista Adventista, December, 1998, 9.

${ }^{119}$ Greenleaf, A Land of Hope, 634. See also “APS Promove Encontros de Treinamento," Revista Adventista, November, 1996, 23; "Nordeste Investe em Pequenos Grupos," Revista Adventista, October, 
seven thousand small groups in the southern part of the country and about ten thousand in northeastern Brazil. The division attributed 45,000 new members to these groups. ${ }^{120}$ During the integrated evangelism period humanitarian projects promoted by Adventist Development and Relief Agency (ADRA) also helped local churches develop a sense of community and impact their contexts. ADRA had a history of acting more in relief interventions than social issues awareness projects in South America. The limited number of natural disasters occuring in Brazil, mainly floods and landslides, restricted ADRA's missionary engagement. In the 2000s ADRA started promoting social consciousness projects such as child abuse and neglect. In 2003, for example, it promoted a widely publicized campaign in cooperation with the church's Women's Ministries Department called "Breaking the Silence." 121

A similar spirit was demonstrated in 2006 when São Paulo Adventists celebrated their centennial. They collected 150 tons of non-perishable food during an event called "Saturday: A World Day of Joy" when an estimated 50,000 people gathered in a stadium and distributed a million pieces of literatures about the Sabbath. ${ }^{122}$ Another example was the national support for Mutirão de Natal. This was a Christmas humanitarian campaign begun in 1993 in Rio de Janeiro. In 2007, when the campaign was promoted nationally,

1997, 35; "Encorajamento e Desafio," Revista Adventista, May, 1997, 27; Erton Köhler, "Pequenos Grupos, Grandes Resultados," Revista Adventista, April, 2002, 26.

120“South America: Church Grows Via Bible Study Groups."

121"Plight of Abused Children Addressed by World Church President," Adventist News Network, accessed November 2, 2014, http://news.adventist.org/all-news/news/go/2003-09-01/brazil-plight-ofabused-children-addressed-by-world-church-president/.

${ }^{122}$ Márcio Tonetti, “Passarela do Sábado,” Revista Adventista, September, 2006, 22-23. 
churches collected 3,200 tons of food. The campaign ended with a program with music and drama performances and the presence of celebrities and political authorities at the Botafogo Church in Rio de Janeiro. ${ }^{123}$

In 2000, more than 2,300 Pathfinder clubs in Brazil joined in fostering community, service, and disciple-making. Their special discipling method included memorizing Bible verses, studying about nature, Christian living, and good citizenship (often with military and patriotic influences, such as the use of uniforms, marching drills, and flag ceremonies). In 2005, 20,000 Pathfinders gathered for the division-wide camporee, which attracted the attention of the national media and authorities. ${ }^{124}$

In 2007, the current division administration took office. While Nagel was a wellseasoned administrator (44 years of service), Erton Köhler, the incoming division president, was a dynamic 38 year-old youth leader. Nagel had been division president for 12 years and his vision for the church focused on unity and mission utilizing one method, integrated evangelism. Köhler, who served as a departmental director at the division, stated at the time of his appointment that he would continue the same philosophy. ${ }^{125}$ At his first meeting for planning division activities, Köhler mentioned that the church should

\footnotetext{
123“"Brazil: New Record for Nationwide Christmas Food Collection Initiative," Adventist News Network, acessed November 2, 2007, http://news.adventist.org/all-news/news/go/2007-12-17/brazil-newrecord-for-nationwide-christmas-food-collection-initiative/; "Mutirão de Natal Consolida Vocação Solidária da Igreja," Revista Adventista, January, 2006, 24-26.

${ }^{124}$ Lemos, "50 Anos de História”; Leo Ranzolin, "Pathfinders Nearly Double Size of Host City," Adventist Review (World Edition), April, 2005; "Brazil: President Highlights Importance of Camporee to Country's Ideals," Adventist News Network, accessed November 2, 2014, http://news.adventist.org/allnews/news/go/2005-01-19/brazil-president-highlights-importance-of-camporee-to-countrys-ideals/.

${ }^{125}$ Rubens Lessa, "Hora de Transição," Revista Adventista, December, 2006, 2. Ruy Nagel, “A Força da União," Revista Adventista, December, 2006, 4.
} 
focus on spirituality, dialogue, and quality. He stressed that Adventist ministers are leaders of a mission, not a structure; evangelism is our mission and integration is our method. ${ }^{126}$

Between 1895 and 2007, the Adventist movement in Brazil emphasized five major mission methods: literature evangelism, public evangelism, radio and television evangelism, metropolitan evangelism, and integrated evangelism. ${ }^{127}$ Over time new emphases appeared and new mission methods were added to the church's overall activities. By 2007, all these methods were seen in Brazil. The dynamics of these mission methods could be illustrated by waves that are higher or lower at different times in history. These waves were definitely higher during the period from its beginning until the introduction of the next mission method. Although the identification of the six elements of an Adventist movement ethos within each mission method has been introduced in this chapter, the next section will consider a more thorough analysis of those dynamics.

126“"Líderes da Dsa Fazem Planejamento,” Revista Adventista, January, 2007, 29.

${ }^{127}$ Several other mission projects that fall outside the focus of this research were developed and implemented since the beginning of the Adventist movement in Brazil at smaller scales, such as district or local church level. Examples include: telephone evangelism, evening adult literacy classes, and audiovisual center. Agax Silveira, "Telephone Plan Successful in Brazilian Cities," Review and Herald, August 14, 1980; Arthur S. Valle, "Audio-Visual Center Serves Evangelists,” Review and Herald, July 22, 1976. 


\section{CHAPTER 9}

\section{THE ETHOS OF THE ADVENTIST MOVEMENT IN BRAZIL: A MISSIOLOGICAL ANALYSIS, CONCLUSION, AND RECOMMENDATIONS}

The primary dynamics of the five major mission methods employed by the Adventist movement in Brazil from its beginning in 1894 until 2007 have been described in the previous chapter. Further analysis in order to point out the relation between those mission methods and the fostering of an Adventist movement ethos will be the focus of this section.

\section{A Missiological Analysis}

\section{A Portfolio of Methods}

The Adventist movement in Brazil, as far as mission methods is concerned, could be described as a sequence of waves. Although most of the methods have been partially present from the early years in the "portfolio" of methods, the denominational emphasis has moved from one to another. For a period of time a certain wave was "higher" and then it gave way to the next one with the following sequence: literature evangelism, public evangelism, radio and TV evangelism, metropolitan evangelism, and integrated evangelism (see figure 5). 


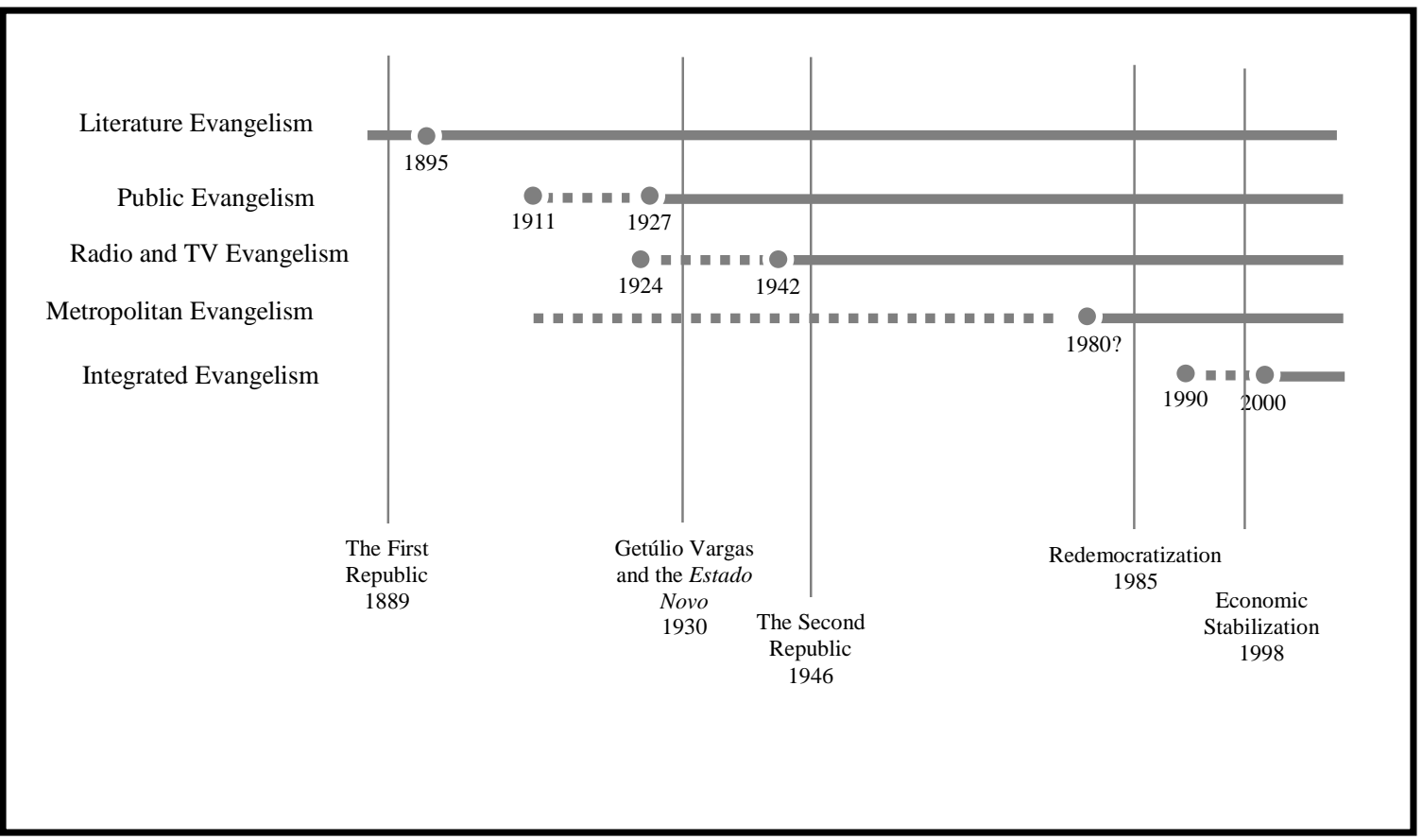

Figure 5. Adventist mission methods in Brazil

Literature evangelism was the approach of the first missionaries to Brazil in 1894.

Public evangelism, although already being practiced, was widely adopted by the South American Division in 1927. The year 1943 marks the first Voice of Prophecy radio broadcast in Brazil and the beginning of radio and television evangelism as a major mission method. Metropolitan evangelism became the division method in 1980. And integrated evangelism was adopted as the primary mission emphasis in Brazil in 1999.

The dynamism of these mission methods, as described and analyzed previously, does not allow for comprehensive and precise definitions. In essence, however, these methods did have some specific features. Literature evangelism involved selling religious books. As contacts were made, colporteurs tried to identify people interested in studying the Bible and to raise that interest in others. Follow-up was provided either by themselves or by full-time ministers who studied the Bible and explained the church's main 
teachings. Those who decided to join the church were baptized and fellowshipped with others who had similar beliefs.

Public evangelism was conducted primarily by ministers, but also by church members. People were invited to attend a series of lectures primarily on Bible prophecy and church doctrines. Those who were convinced of the teachings presented and decided to join the Adventist church were baptized.

Radio and television evangelism was characterized by Voice of Prophecy broadcasts. Listeners of those messages about Adventist doctrines had the opportunity to sign up for correspondence Bible study lessons. Baptism and fellowship at church were also the goal.

Metropolitan evangelism was an initiative that focused on doing public evangelism to larger audiences. Two models were employed: evangelistic series on doctrines conducted at multiple sites in an urban setting for several months and short series (3 to 8 nights) on salvation conducted at a stadium for thousands of people.

Integrated evangelism was an attempt to include all levels of the church in missionary efforts. Initial efforts focused on signing up people for the 12-lesson Interactive Bible Survey Course, which was offered at the same time on TV and radio.

Just as important as the distinction between mission methods in the Adventist movement in Brazil is the relation between them. As soon as the first ordained ministers arrived in Brazil, literature evangelists began to share the work. Public evangelists, such as Schubert, also looked for areas that had already been visited by literature evangelists to conduct their meetings and radio and television evangelism based its work on other methods. Literature and public evangelists identified themselves with the Voice of 
Prophecy and looked for interests, but also offered the correspondence course to their audiences. In some ways a hybrid model resulted from those dynamics. The Voice of Prophecy speaker and the quartet began touring and conducting "lightning conference series"- short reaping events aimed at large audiences. Metropolitan evangelism also tried to combine the previous experiences: the search for large audiences, an emphasis on sowing, reaping, and keeping, and the mobilization of evangelists, institutions, and laity. Finally, integrated evangelism's proposal was to consolidate the synergy between different evangelization fronts in a "well-planned, integrated program of sustainable growth for the church."1

This overview of the mission methods of the Adventist movement in Brazil indicates two features. First, the Adventist movement developed a portfolio of five major methods. Over time, different dynamics were adopted as part of the process of evangelization. Second, all the methods were connected by one factor: evangelism. This feature becomes more evident when considering the relation between those methods. Evangelism in this case does not refer to a strategy or a process but to a broader understanding that has provided the foundation to the different methods developed in Brazil.

The rapid development of the Adventist Church in Brazil took place at the same time that the country was going through social change. It should also be observed that, in general, the Adventist movement emphasized a different method at each of the main periods of the history of Brazil since the end of the empire. As demonstrated in the

${ }^{1}$ Timm, "Building a Growing Church." 
previous chapters, the following correspondence is observable: literature evangelism and the first republic, public evangelism and Getúlio Vargas and the Estado Novo, radio and television evangelism and the second republic and Military Rule, metropolitan evangelism and redemocratization, and integrated evangelism and economic stabilization.

A closer look at the relation between the socio-political environment and mission methods leads to further observations. The beginning of the Adventist movement in Brazil, for example, happened at a very propitious time for Protestant missionaries, as mentioned in the previous chapter. Other denominations also took advantage of the new religious openness that resulted from the end of the Empire. Public evangelism benefitted from the disillusionment that characterized the period after World War I. People became more open to alternative suggestions that gave them hope. Radio evangelism took advantage of new technology to spread the Adventist message to a wider audience. Metropolitan evangelism and its focus on urban centers followed the urbanization trend in the country. And integrated evangelism, based on strong institutions, was favored during a period of a stable economy.

Observation indicates that the pattern of activities by the Adventist Church in Brazil followed primarily after the American model missionaries were used to and the instructions received from the General Conference. However, there are indications of direct and indirect socio-economic-political influences. Despite the lack of missiological studies to guide this process, development of new mission methods in Brazil have been unintentionally influenced by contextual changes.

The Adventist Movement Ethos Model in Brazil

After describing the relation between Adventist mission methods in Brazil, it is 
also necessary to conduct a more specific missiological analysis of the six elements of the Adventist movement ethos.

\section{Christ: Savior, Lord, and Priest}

The distinctive Adventist message was present in Brazil from the very first and had a strong influence in shaping the worldview of the Adventist movement in Brazil and, consequently, of its ethos.

Apparently for the first four decades of the Adventist movement in Brazil, evangelistic series exclusively emphasized Bible prophecy when starting a series in order to attract an audience. Voice of Prophecy broadcasts in Brazil also had prophecy and doctrines as the core of their message. Eventually radio programs and Bible study guides adopted a few other subjects related to spiritual values and social issues. Nonetheless, the primary emphasis was underlined by the name of the broadcast.

As metropolitan evangelism took place in the 1980s the Adventist movement witnessed the most dramatic change in the content of its message so far. Alejandro Bullón introduced the topic of the importance of a relationship with Christ as the primary emphasis of public evangelism. Although some were shocked and resisted the new approach, the large audiences that attended his preaching seemed to indicate that Bullón had identified a legitimate need. Toward the end of the 1990s and 2000s other evangelists returned to the traditional emphasis on Bible prophecy and church doctrines.

A common observation was that the traditional prophetic approach was more fit for a majority-Protestant population that already had a common understanding about the Bible and God's plan of salvation, something that was not the case in majority-Catholic Brazil. Another part of the issue was the formality of the public evangelists' lectures. The 
highly cognitive emphasis of the traditional North American-inspired model had little relevance for the lower educated audience in South America. The distinctiveness of the Adventist message, however, was necessary to help shape the movement's unique identity and mission which was aligned with the original movement in the United States as described in chapter 6 .

\section{Missional-Incarnational Impulse of the Coming of Jesus}

The issue of contextualization and mission strategizing was also present from the very beginning. The decision about the first mission method, literature evangelism, involved different opinions. Apparently, the Foreign Mission Board had at least three options: health care, favored by L. C. Chadwick; schools, favored by W. C. White and William A. Spicer; and colporteuring. ${ }^{2}$ Another church leader connected with the Foreign Mission Board, Percy T. Magan, had given important insight on South American society prior to that decision. He counseled about the importance of speaking the three basic languages of the European-descent population: French, Spanish, and German.

We must commence with those whose manners, customs and habits are most nearly akin to our own, and then by degrees as the providence of God shall open, work our way to those who are separated form us by all their habits and customs of life, to say nothing of their languages and forms of government. ${ }^{3}$

The choice by the Foreign Mission Board to employ literature evangelism seems

\footnotetext{
${ }^{2}$ W. A. Spicer, "Mexico," The Home Missionary, V, June 1893, 100-101; W. C. White, "The Argentine Republic," The Home Missionary, II, June 1890, 124-125. Chadwick, in 1891, traveled Latin America on a survey tour to investigate prospective missions. As a result, for example, in Spanish-speaking Central America he advised no work, in Jamaica, medical work, and in other places, literature distribution. Greenleaf, A Land of Hope, 27-28.
}

${ }^{3}$ Percy T. Magan, "South American," The Home Missionary, II, Extra, November, 1890, 244-245. 
to have relied more on that advice. Self-supporting colporteurs were also important for the young denomination to keep its costs low, to not divert the lean working forces in the United States, and to still be able to enter more countries. Literature distribution was very much a part of the missionary ethos of the Adventist movement in North America where it helped nurture church members spiritually and fostered unity in the movement.

Although one cannot fully imagine what the results of adopting a different strategy, such as education, would have been, the insightfulness of Magan's advice that pointed out elements that would impact the effective communication of the Adventist message should be noted. His observation was made long before Donald A. McGavran developed the Homogeneous Unit Principle, for example, and before most of the intercultural communication studies were conducted.

It is also necessary to point out the existence of a specific mission board, which indicated the priority of world mission despite the limitations of the still small Adventist movement. Nonetheless, the strategic planning seems to have been restricted to the predeployment phase. Except for the focus on German-descent areas, one can hardly say there was any strategy, for example, to transition to the Portuguese speaking population or to focus on specific regions of the country.

Soon after the beginning of literature evangelism in Brazil, missionaries realized their limitations. They were not prepared for the conditions they were facing: an unstable economy and politics, extreme weather, poor means of communication and transportation, besides the language barrier. Their lack of preparation and planning on their incarnational side was compensated to a certain extent by their strong missional fervor. Literature evangelists, by the very nature of their activity, were very missional and 
went after people instead of waiting for them to be interested in what they offered. There is no shortage of accounts of missionaries making sacrifices for mission. During the initial period of this method fervor and dedication of public evangelists as they traveled long distances and stayed away from home for several months a year was a common occurrence.

The adoption of public evangelism as the major division method in the late 1920s seems to have been motivated by the impulse to multiply the missionary reach. Public evangelism was once again an intrinsic part of the Adventist movement fabric. Inherited from the Millerite movement, this model was widely used in the United States, as described in chapter 6.

The incarnational advance that took place with Schubert deserves special consideration. Contextualization efforts by this main evangelist of the South American Division shaped the application and increased the effectiveness of this mission method in Brazil. This came after a disappointing experience, good advice by an observant church member in Argentina, and much experimentation. There was little intentionality and no formal missiological training but much willingness and boldness to try new ways to communicate the Adventist message effectively. While meeting audiences' felt needs and building bridges became key to those initiatives, Schubert's missionary acuteness is also identified in his strategy to travel to communities that had been visited by literature evangelists. In Greenleaf's assessment, the importance of Schubert's adaptation was that his audiences were exposed to "Adventist sensitivity to social issues. . . The credibility of both the speaker and the Bible derived from explanations of the relationship of 
Scripture to health, family, and other social problems. ${ }^{4}$

The new focus on radio and television evangelism was consistent with the Adventist mentality that led to a search for methods that could reach ever more people with the Adventist message. It also demonstrates that the work in Brazil was still aligned and influenced by what happened in the United States where radio evangelism was a reality. Finally, the introduction of this method in Brazil revealed the willingness to adopt and experiment with new technology.

Missional efforts had to be matched with incarnational ones. Small contextualization steps took place very slowly and timidly. Eventually, radio and television evangelism had to move toward having a speaker with scripts and a group of singers from Brazil. The themes of the broadcasts and correspondence Bible study courses became increasingly associated with the local context and focused on the demographics of their audiences as well.

Radio evangelism contributed to the mission of the Adventist movement in some ways. First, it opened doors and broke down walls of prejudice against the Adventist Church. Part of these efforts included avoiding the name of the Adventist Church on air. Second, it reached groups of people that were not reached in other ways. Access to radio was more accessible among the elite, for example. Finally, it became part of the process of conversion of many people especially because, as Roberto César de Azevedo points out, "a conversion directly resulting from radio was not easily defined."

${ }^{4}$ Greenleaf, A Land of Hope, 484.

${ }^{5}$ While these numbers are impressive, Roberto Cesar de Azevedo, South American educator and researcher, observes that a conversion directly resulting from radio was not easily defined 
The missional-incarnational impulse was evidenced by different initiatives. An example includes mission projects focused intentionally on unreached geographic areas. During the 1970s, apparently, for the first time, the church realized it had grown and was present in many places around the country but it did not follow an even pattern. Before that, the focus was only on expansion, now it was a matter of being present everywhere. Azevedo "pointed out that entering municipalities where no Adventist presence existed was still occurring so slowly that more than sixty years would pass before the church could say it had covered just the country of Brazil." ${ }^{\prime 6}$ This concept was also impacted by early Global Mission thought that committed to having an Adventist presence among every 1 million people.

\section{Apostolic Environment within the Great Controversy}

A shortage of personnel led literature evangelists and ministers to rely on local lay mobilization in the early years. ${ }^{7}$ During times of travel and long absence of the missionaries, local elders, deacons, and other church members conducted Sabbath school classes, worship services, and outreach programs. Despite the time spent training lay leaders in the beginning, the personal influence of missionaries was the most important element to develop a fertile environment for mission. Their dedication was a prime example of the integration of the Adventist message in their daily lives.

${ }^{6}$ Greenleaf, A Land of Hope, 614. Azevedo, who suggested that the number of municipalities with an Adventist presence was the best indicator of evangelistic efficiency, conducted a study that pointed out that, despite the high figures, the church had been growing very unevenly.

${ }^{7} \mathrm{An}$ example is the fact that in December 1936, the East Brazil Union still had only 36 workers serving 36 million inhabitants - a ratio of one worker for every million people. Ibid. 
The first public evangelism models engaged lay members in giving Bible studies and conducting health lectures and evangelistic series at satellite locations. W. A. Butler, during his visit in 1938, was excited to see the number of lay members involved in mission. Acknowledging the importance of church members in that process, in the 1950s, the church began to offer more structured training programs. In the 1970s, the year of the layman was emphasized more than once. Church leaders felt the need to rely on church members and so took the responsibility to empower them.

Radio evangelism introduced an impersonal technology that took part of the missionary process away from the laity. Aware of this reality church leaders sought other ways to involve lay members in evangelization, including praying, advertising, and becoming the link between the radio program and interests.

During the metropolitan evangelism period, lay members were motivated to make friends with people, study the Bible with them, and invite them to come to large gatherings for reaping events. Both the message and the practice were geared toward relationships. There was a more intentional attempt to combine personal and public evangelism.

More recently, the emphasis on small groups has been another attempt to keep the relational aspect of evangelism and the involvement of lay members in that process. Nonetheless, over the years, the Adventist movement has seen a trend toward a professionalization of mission. The interest in reaching ever larger audiences and an emphasis on the growth the church has become increasingly dependent on professional evangelists while the role of lay members has become more limited to supporting the specialists' efforts. In 2000 the division officers concluded that, in South America, 
evangelism was not a "passing strategy," but a normal, permanent, and constant $\operatorname{program}^{8}$

\section{Spiritual Organic Systems}

The Adventist work in Brazil did not have a formal local structure in the beginning. Mission depended on the synergy between colporteurs, ordained ministers, and church members, and their connection with the larger denominational structure. The rapid organization of the first conference, the Brazilian Conference, and the presence of other institutions in 1902, as well as the quick multiplication of conferences suggest that formal organization was part of the mindset of those first denominational missionaries. Especially J. W. Westphal, the first leader of the Adventist Church in Brazil, believed in the role of institutions and worked for the development of them. During the first years the organization seemed to be organic enough to allow for spontaneous and hyperbolic development.

During the first decades of the work in Brazil it is easy to identify how the development of institutions helped the missionary efforts of the Adventist movement.

Schools, health-care projects, and printing houses drew the public attention and gave stature to Adventists. ... Ownership of buildings, implementation of a multiplicity of programs serving a common purpose, and employment opportunities in a variety of institutions added to the character of the church. Institutions also provided something with which Adventists in South America could identify. These were visible aspects of what Adventists like to call the "movement" or the "cause."

\footnotetext{
${ }^{8}$ Nagel, "Our People on the March.“

${ }^{9}$ Greenleaf, A Land of Hope, 68.
} 
Key denominational leaders, such as Carlyle B. Haynes and Enoch de Oliveira, helped keep a missionary focus and the unity of the church structure in Brazil. That included decentralizing the management of funds and the decision-making process. ${ }^{10}$ They also watched closely the involvement of ministers to ensure that they had time and resources for evangelistic projects. ${ }^{11}$

Radio and TV ministries were gradually accepted as part of the core missionary efforts of the church. Many church leaders and local pastors found it difficult to understand how the intangible results of those ministries would collaborate with their plans. The acceptance of media ministries is at least partly related to establishing institutions to host them and becoming the object of investment by the organization.

When metropolitan evangelism was adopted, there seemed to be two ways of thinking. Bullón understood that mission should not be exclusively dependent on the structure of the church because global mission depended on personal involvement since pastors, teachers, and others in the structure would never be able to go where lay members could go. ${ }^{12}$

\footnotetext{
${ }^{10}$ After World War II foreign church administrators began a transition to national leaders. The common Brazilian people belief that they had been subservient for too long made its way into the church organization. The issue of the overseas worker focused on the question of foreign presence and North American dominance in church governance. Greenleaf, A Land of Hope, 592, 593, 597.

${ }^{11}$ In 1947, division committee members "requested conference and mission directors to arrange pastors' schedules to allow them to devote the 'major portion' of their time to 'aggressive evangelism' rather than to pastoral duties." The resolution voted by that committee stated that they were "encumbered with too many tasks that are secondary to our basic purpose as a movement" and it observed that the ministry was too occupied with "organizational and functional duties." Ibid., 401.

${ }^{12}$ Bullón, “O Sol da Aurora Eterna Já Desponta no Horizonte,” 9.
} 
At the same time, institutions and all church departments were expected to be a part of the division missionary efforts. As the denomination matured in Brazil and had its first Brazilian division president, institutions continued to develop. Judging by the number of members and institutions, Greenleaf is correct in stating that "in 1980 Seventh-day Adventism in South America was no longer a small movement in out-ofway corners of the continent."13

By 1980, Superbom, the health food manufacturer was well established. In 1985, the Adventist Church reached the highest number of beds in its hospitals. Around the same time, the publishing house committed to a major relocation in order to continue expanding. Enrollment at denominational schools continued to grow. In the last thirty years, the positive contribution to missionary plans by institutions has been affected by the economic situation of the country, other church priorities, and the managerial inability, in some cases, to deal with them. A common trend at the time was to appoint managers for Adventist institutions who had been church pastors and had no business administration training. In the meantime, the Adventist Church in Brazil has become increasingly institutionalized. ${ }^{14}$

\section{Community for God}

Pioneer missionaries tried to foster a strong sense of community among the scattered groups through their visitation program and extensive itineraries. Literature was an important unifying element in the first stage of the Adventist work in Brazil. The

\footnotetext{
${ }^{13}$ Greenleaf, A Land of Hope, 603.

${ }^{14}$ Ibid., 605, 650.
} 
believer's common experience as a small and marginalized movement produced the liminality that helps define a true community.

As the Adventist group grew new dynamics helped foster fellowship among church members. Missionary Volunteer (MV) societies, for example, became good opportunities for fellowship among young people. Youth congresses also became popular programs to help Adventist members from different communities meet and fostered a sense of belonging to a larger movement. Those youth meetings became large multi-day events with sophisticated productions. During those gatherings young people had a chance to make new friends, develop their relationship with Christ, and become involved in the local community through social outreach projects.

As the institutions solidified they contributed to the sense of community among Adventists. Besides literature, Adventist schools were another important part in the denominational community since they were responsible for educating children. Media ministries, such as Voice of Prophecy, also fostered a sense of community among church members in such a large country. The above activities added to their sense of belonging and identity as one large group.

Traditionally, the fellowship of Adventists in Brazil and most of their interactions with the local community revolved almost exclusively around mobilization for evangelistic programs, such as evangelistic series or invitations for Bible studies. More recently small groups have had the objective of fostering relationships within congregations, while offering the opportunity to meet non-Adventists.

Humanitarianism has not been as strong in the Adventist movement in Brazil as in other places, such as Central America. Although poverty has always been an issue in the 
country, perhaps the low incidence of natural disasters and the emphasis on the spiritual nature of Adventist evangelization with little consideration of social issues explains that scenario. An exception is the riverboat ministry in the Amazon, which grew significantly during the 1940s and developed well into the 1980s when it came to an end. That pioneer incarnational ministry was composed of education, health, and evangelism. Other Adventist initiatives have included stop smoking programs and Pathfinders clubs. In the 2000s ADRA found new ways to promote social projects, such as programs to reduce child abuse and neglect, thus allowing church members to interact with their communities at a new level.

\section{Disciple-making for Eternity}

The different methods of evangelization relate in specific ways to the process of disciple-making. Literature evangelism focused on the initial steps, including personal contact and sale of Adventist literature, and sometimes a follow-up visit by a minister. After baptism, the purpose was to get each person involved in the church, which included attending general meetings, becoming a colporteur, and attending an Adventist school. ${ }^{15}$ As the movement grew in Brazil, other dynamics helped foster spiritual growth and fellowship of its members, such as the Missionary Volunteer societies and Sabbath schools classes. Public evangelism became the main method.

Probably the most critical aspect of radio and television evangelism was the follow-up. Since Adventists aimed at baptism and fellowship, it was difficult to meet

\footnotetext{
${ }^{15}$ As Greenleaf observes, "by 1911, it was clear that since their arrival in South America, ministers had evangelized on a relatively small scale, following interests generated by literature distribution or preaching to small groups resulting from personal witnessing." Greenleaf, The Seventh-day Adventist Church in Latin America and the Caribbean, 112.
} 
listeners who were scattered and identified with the broadcast only by its name. It was a known fact that people ended up in other churches because they did not relate the Voice of Prophecy with the Adventist Church. This situation could have been much worse were it not for the correspondence school and its Bible lessons. Probably the most significant element in the discipleship process, however, was the excitement and involvement of lay members that gave presence, embodiment, and proximity to the broadcasts. During this period, disciple-making was expected to be a result of laity involvement. They were responsible for making contacts, offering Bible studies, taking listeners to evangelistic series, and following up with them.

Global Mission efforts also had the potential to offer important disciple-making dynamics since they focused on unreached people groups and territories with an emphasis on personal witnessing. In practice, global mission did not make a big impact, perhaps because it was primarily seen as a program for specialized missionaries and it resulted in fewer baptisms in comparison to the large evangelistic campaigns.

The involvement and excitement with public evangelism also generated a challenging situation with retention rates. ${ }^{16}$ Greenleaf points out that Enoch de Oliveira, division secretary, mentioned the problem of apostasies in his annual report for 1970 . He showed that during the previous decade Adventists had left the church at rates varying from 14 to 42 percent. Although one of the reasons for this situation probably included the lack of keeping the membership books updated, "since the 1950s division and union

\footnotetext{
${ }^{16}$ As Greenleaf points out, "The division committee constantly monitored the new evangelistic fervor, but a problem that appeared to be lost in the enthusiasm was the question of net growth." Greenleaf, A Land of Hope, 401.
} 
leaders consistently set goals beyond their reach, but they were consistently amazed by actual church growth." ${ }^{17}$ In 1983, for example, when the issue of membership loss was discussed again, delegates issued the Declaration of Buenos Aires committing themselves to not only sowing and reaping but also keeping new members as part of their evangelistic programs. They also indicated that much of the responsibility to keep members belonged to local church leaders. ${ }^{18}$

Skeptics tended to view high apostasy rates as evidence that massive evangelism resembled a dragnet operation more than a soulwinning activity. . . . Converts in recent years were left to learn more about Adventism after baptism, which contrasted with the experience of their spiritual forebears who concentrated more on an understanding of Scripture before their baptism, including distinctive Adventist belief. $^{19}$

More recently, in 2006, the North Brazil Union underwent a review of its more than 196,000 members. Once again sloppy bookkeeping may be a part of the explanation, but "it is likely that because church leaders were handling such large numbers of membership accessions, they also faced the problem of hasty baptisms and apostasies."20 These facts indicate that Adventism grew in Brazil, but not without problems.

\section{Conclusion}

\footnotetext{
${ }^{17}$ Ibid., 483. Greenleaf points out that "during the best of years, a 90 percent net gain was a difficult level to achieve for even a moment, not to speak of sustaining it for five years." In 1974, for example, the percentage was not as nearly positive since there were 37,500 baptisms and 30,000 losses. Ibid., 482; General Conference of Seventh-day Adventists, Annual Statistical Report (1974).

${ }^{18}$ Greenleaf, A Land of Hope, 634.

${ }^{19}$ Ibid., 635.

${ }^{20}$ Ibid., 624.
} 
That the growth of the Adventist Church in Brazil surprised even the leaders' best dreams is probably not an overstatement. However, one should avoid the temptation to believe that that missionary phenomenon was either an accident or exclusively a consequence of an extraordinary receptive society. ${ }^{21}$

Different church leaders have offered short explanations for the Adventist experience in Brazil. In 1957, W. R. Beach, General Conference Secretary, attributed “Adventists' success in Brazil to a well-integrated evangelistic program and strong institutions. ${ }^{22}$ In 1986, William G. Johnsson, Adventist Review editor, pointed out that growth was the result of many factors that included "time-tested methods, enthusiasm, and especially a receptive public, a well-defined sense of church identity, and an abundance of youth and energy." ${ }^{, 23}$ More recently, Greenleaf has commented that "for many South American Adventists formal witnessing became a way of life."24

A brief analysis of the Adventist movement in Brazil, according to the proposed ethos model, suggests more specific findings. Clearly, the Adventist Church has grown and developed as it has relied on different mission methods. And, even after discounting some of the obviously triumphalist enthusiasm found in the church leaders' reports and official sources of information, one is able to identify signs of a movement motivated by its mission. In many ways, the overall lesson of this analysis is the importance of fostering mission as a way of living that is at the core of an Adventist movement.

\footnotetext{
${ }^{21}$ Timm, "Building a Growing Church."

${ }^{22}$ W. R. Beach, “God's Work Is Onward in Brazil," Review and Herald, March 27, 1958.

${ }^{23}$ Greenleaf, A Land of Hope, 627. William G. Johnsson, "Where Laypeople Run the Church," 10.

${ }^{24}$ Greenleaf, 495 .
} 
This analysis of the development of the Adventist movement in Brazil, however, should not lead one to conclude that this positive experience is the result of exclusive human activity. The limitations, shortcomings, struggles, and mistakes help one remember that the successful outcomes were more than a combination, for example, of correct theology, denominational programs, and artificial humanistic motivation techniques. Because mission belongs to God, it is important to acknowledge the spiritual dimension of the Adventist experience in Brazil. As Enoch Oliveira already pointed out in 1969 , the satisfaction of success is the greatest fear in these cases. He warned church workers about "the subtle effects of spectacular growth, institutionalism, and the tyranny of the ecclesiastical machine, in short, a caution not to allow the bigness of the church to become a substitute for the genuine source of authority and power." ${ }^{25}$ In 1980, Oliveira placed the analysis of the Adventist mission in Brazil in the right perspective by highlighting God's direct intervention in it. He said that "the tremendous growth of the Adventist work in South America can be appreciated only when viewed in terms of a miracle wrought by the Holy Spirit working through a faithful and dedicated people, and a ministry motivated by a consuming passion for lost souls. How else could we explain this phenomenon of evangelistic growth?"26

\footnotetext{
${ }^{25}$ Greenleaf, A Land of Hope, 603.

${ }^{26}$ Ibid., 604.
} 
The rapid development of the Adventist Church in Brazil took place at the same time that the country was participating in the modernization of Latin America that resulted in the country achieving new economic, political, social, and religious status. ${ }^{27}$

As a major player in the world scene, global trends continue to impact Brazilian society. The many changes may be traced to three main forces-globalization, integration, and democratization — factors that promise to make Latin America in the twenty-first century noticeably different from before. ${ }^{28}$

Brazilian demographics have gone through major changes during the turn of the millennium. The latest census indicates an accelerated aging population and a reduction of fertility rates that are restructuring the age pyramid. It also points out that more than half of the population declared itself to be brown or black. ${ }^{29}$ There was a major decline in the national illiteracy rate in the past ten years while the number of higher education students more than doubled during the same period. ${ }^{30}$ The results of the latest census also

\footnotetext{
${ }^{27}$ See Skidmore and Smith, Modern Latin America and Skidmore, Brazil, 180-255, for an ample discussion on that transformation. Part three, the social challenges in Latin America, of Viera-Rossano's dissertation allows for an interesting comparison between an Adventist reading of that context just a little over 20 years ago and now. Juan Carlos Viera-Rossano, "Seventh-day Adventists in Latin America: Their Beginnings, Their Growth, Their Challenges” (PhD diss., Fuller Theological Seminary, 1993).

${ }^{28}$ Peter Calvert, "Latin America: An Introduction," in South America, Central America, Caribbean 2003 (London: Europa Publications, 2002), 10. James Beckford offers a brief reflection on the relation between religious movements and globalization, even citing the Adventist Church, in his chapter in Cohen and Rai, Global Social Movements. 2012).

${ }^{29}$ Instituto Brasileiro de Geografia e Estatística, Censo Demográfico 2010 (Rio de Janeiro: IBGE,

${ }^{30}$ Instituto Nacional de Estudos e Pesquisas Educacionais Anísio Teixeira, Censo da Educação Superior: 2010 - Resumo Técnico (Brasília, Brazil: Instituto Nacional de Estudos e Pesquisas Educacionais Anísio Teixeira, 2012), 39.
} 
improved the accuracy of the information about the native population in Brazil, listing 305 native ethnic groups and 274 native languages. ${ }^{31}$

Urbanization is another global trend that is changing Brazil. According to Jenkins, 80 percent of the largest urban conglomerates are in Asia and Latin America. ${ }^{32}$ In Brazil, $85.4 \%$ of the total population live in urban areas. The metropolitan area of Sao Paulo, the largest Brazilian city, had a population of 20.9 million people in $2014 .^{33}$

The direct economic consequences of those forces also include lower inflation, expanding credit, liberal trade, government welfare programs, and a new emerging middle class comprised of millions of people who are "the main beneficiaries of the region's hard-won economic stability."34

According to official government numbers, from 1999 to 2009, 31 million people entered Brazil's middle class, which corresponded in 2009 to 95 million people (52\% of the population). ${ }^{35}$ This group has acquired new habits and displays different needs. They look for quality products, they press for more women's participation in the job market, and they demand access to the Internet and information. The new Brazilian middle class

\footnotetext{
${ }^{31}$ Instituto Brasileiro de Geografia e Estatística, “Censo 2010: População Indígena é de 896,9 Mil, Têm 305 Etnias e Fala 274 Idiomas,” accessed January 10, 2016, http://saladeimprensa.ibge.gov.br/ noticias.html? view=noticia\&id= 1 \&idnoticia=2194\&busca=1\&t=censo-2010-populacao-indigena-896-9mil-tem-305-etnias-fala-274.

${ }^{32}$ Jenkins, The Next Christendom, 107-108.

${ }^{33}$ Instituto Brasileiro de Geografia e Estatística, "IBGE Releases Population Estimates of Municipalities in 201," accessed May 28, 2015, http://saladeimprensa.ibge.gov.br/en/noticias? view=noticia\&id=1\&idnoticia= 2704\&busca=1\&t=ibge-releases-population-estimates-of-municipalities-in2014.

34“"Adiós to Poverty, Hola to Consumption,” The Economist, 8/16 2007.

35“"Brazil's Middle Class in Numbers,” accessed October 8, 2015, http://www.brasil.gov.br/para/ press/press-releases/august-1/brazils-middle-class-in-numbers/br_model1?set_language=en.
} 
accounts for $78 \%$ of supermarket purchases, $70 \%$ of credit card holders, and $80 \%$ of Brazilians with Internet access. ${ }^{36}$ In 2010, 5 million people left Brazil for an international destination. $^{37}$

Perhaps the most relevant trend is related to the new Brazilian religious landscape. Trends include more religious diversity through an increase in the number of Protestants but also unaffiliated groups and other religions. Jenkins estimate that the second largest Christian communities in 2050 will be in Brazil (195 million). ${ }^{38}$ Brazil, which has always been overwhelmingly Catholic, today, has the largest number of Catholics in the world — around 123 million. However, that number has been dropping steadily (from $92 \%$ in 1970 to $65 \%$ in 2010) while the number of Protestants has been increasing (from 5\% in 1970 to $22 \%$ in 2010). The trend is primarily a result of the growth of Pentecostal and neo-Pentecostal churches, such as the Universal Church of the Kingdom of God, but also of other mainline groups such as Adventists. Pentecostals grew from $6 \%$ of the total population in 1970 to $13 \%$ in $2010 .{ }^{39}$ Historical Protestants grew $1 \%$ during the same period.

\footnotetext{
36“Additional Facts on Brazil's Middle Class," accessed October 8, 2015, http://www.brasil.gov .br/para/press/press-releases/august-1/brazils-middle-class-in-numbers/br_model1?set_language=en.

37، A Cada Dez Turistas Brasileiros, Apenas Um Viaja Para O Exterior,” accessed January 1, 2016, http://www.brasil.gov.br/para/press/press-releases/august-1/brazils-middle-class-in-numbers/br_model1? set_language $=$ en.

${ }^{38}$ Jenkins, The Next Christendom, 104. Other countries with over 100 million Christians will be the United States (330 million), Mexico (145 million), the Philippines (145 million), Nigeria (123 million), and the D. R. Congo (121 million).

${ }^{39}$ Instituto Brasileiro de Geografia e Estatística, "2010 Census: Number of Catholics Falls and Number of Protestants, Spiritists, and Persons without Religion Records Increase," accessed January 10, 2016, http://saladeimprensa.ibge.gov.br/noticias.html?view=noticia\&id=1\&idnoticia=2194\&busca= $1 \& \mathrm{t}=$ censo-2010-populacao-indigena-896-9-mil-tem-305-etnias-fala-274.
} 
Religious switching is the main factor responsible for the growth of

Protestantism, ${ }^{40}$ which, during the last four decades, has become predominantly urban, young, and female. ${ }^{41}$ Two other groups that have increased significantly in the last four decades are the unaffiliated (from 1\% 1970 to $8 \%$ in 2010) and other religions, such as Afro-Brazilian faiths, Spiritist movements, and other world religions (from 2\% in 1970 to $5 \%$ in 2010). ${ }^{42}$

Finally, postmodernity is shaping the way of living in the country. As the French philosopher Michel Maffesoli stated, Brazil is a "living laboratory of postmodernity," primarily because of three main social aspects: creativity, present orientation, and sense of community. ${ }^{43}$ Brazil is definitely not the same as it was a few years ago as all the major transformations have occurred within a generation. These changes have affected, and continue to affect, the Brazilian worldview. As Peter F. Drucker explains:

Every few hundred years throughout Western history, a sharp transformation has occurred. In a matter of decade, society altogether rearranges itself-its worldview, its basic values, its social and political structures, its arts, its key institutions.... And

${ }^{40}$ PewResearchCenter, “Brazil's Changing Religious Landscape,” accessed January 10, 2016.

${ }^{41}$ Catholicism in Brazil is older, rural, and slightly more male.

${ }^{42}$ Estatística, "2010 Census: Number of Catholics Falls and Number of Protestants, Spiritists, and Persons without Religion Records Increase.“

${ }^{43}$ Isabela Vieira, "Brasil Tem Três Chaves da Pós-Modernidade, Diz Sociólogo Francês," 2015, no. 5/28 (2014), accessed January 17, 2006, http://agenciabrasil.ebc.com.br/cultura/noticia/2014-11/michelmaffesoli-brasil-tem-tres-chaves-da-pos-modernidade. For an introductory discussion on postmodernity in Brazil see also Carmen Rial, "O Brasil e a Pós-Modernidade," Revista de Ciências Humanas 10, no. 14 (1993); Alfeu Olival Barreto Junior and Idemburgo Pereira Frazão Felix, "Identidades: No Enredo da PósModernidade no Brasil," Revista Eletrônica do Instituto de Humanidades UNIGRANRIO 9, no. 33 (2010); Eduardo F. Coutinho, "Postmodernism in Brazil," in International Postmodernism: Theory and Literary Practice, ed. Johannes Willem Bertens and Douwe Wessel Fokkema (Philadelphia, PA: John Benjamins, 1997); John Beverley, Michael Aronna, and José Oviedo, The Postmodernism Debate in Latin America (Durham, NC: Duke University Press, 1995). 
the people born into that world cannot even imagine the world in which their grandparents lived and into which their own parents were born. ${ }^{44}$

As Jenkins suggests, if one wants 'to visualize a 'typical' contemporary Christian, [one] should think of a woman living in a village in Nigeria, or in a Brazilian favela." Furthermore, he views that as the new norm, since "far from being an export of the capitalist West, a vestige of Euro-American imperialism, Christianity is now rooted in the Third World, and the religion's future lies in the global South."45

Evangelization by Protestant denominations, including the Adventist Church through traditional methods has become very challenging in face of the contextual changes and the increasing institutionalization. The initial phase of the Adventist movement in Brazil has typically been characterized by an ethos of a missionary movement, which has faded with time, as concluded in the previous chapter.

The Adventist Church in Brazil is moving towards the cycle all denominations face and is on the brink of starting to decline (see figure 6). It seems that the Adventist Church has been enjoying a period of stability and maturity, maximized efficiency, little growth, little risk taking, and strong institutionalization for some time. A contributing sign associated with this position of a church on a downward curve would be an explosion of new supporting lay ministries that seek to bring missionary vitality to the movement and to rescue the missionary movement ethos.

\footnotetext{
${ }^{44}$ Peter F. Drucker, Managing in a Time of Great Change, The Drucker Library (Boston, MA: Harvard Business Press, 2009), 53.

${ }^{45}$ Jenkins, The Next Christendom, xi, 2.
} 
Therefore, after taking into consideration the major global postmodern shift in philosophical understanding and globalization, the contextual changes in the Brazilian scenario, and the serious challenges concerning the Adventist Church's identity as a movement and a denomination, ${ }^{46}$ the conclusion is that the Adventist Church in Brazil is witnessing a convergence of external and internal influences at three different levels: global, national, and denominational.

These changes do not necessarily point to hopeless decline of the denomination in Brazil at this moment. They can be taken as threats or opportunities. The different outlooks concerning the present and future realities of the church are largely dependent on major decisions that should be taken on how to engage the present scenario.

To keep on doing the same things or to just make cosmetic adjustments will not be enough to fulfill God's mission. A yellow light has been on for a few decades regarding the declining (or at least stagnating) situation of the Adventist Church in Western Europe and North America. The Adventist Church in Brazil may be going down the same path and repeating history.

To humbly follow the Holy Spirit's guidance, intentionally rediscover biblical principles, and boldly engage the current context would redirect the church toward new horizons. True church revival and reformation for mission and the rekindling of an Adventist missionary movement ethos could draw a sigmoid curve and mean a new chapter and a new upward trajectory in the history of the Adventist Church in Brazil.

\footnotetext{
${ }^{46}$ On a larger level, Knight points out four specific challenges for the Adventist Church: (1) keeping its identity as an aging denomination; (2) keeping a "healthy middle-of-the-road balance" avoiding "acculturation to the larger community" and "segregation into a sectarian ghetto"; (3) keeping a healthy balance between congregationalism and overinstitutionalism; and (4) keeping its vision of itself as a people of prophecy. Knight, William Miller and the Rise of Adventism, 287-290.
} 


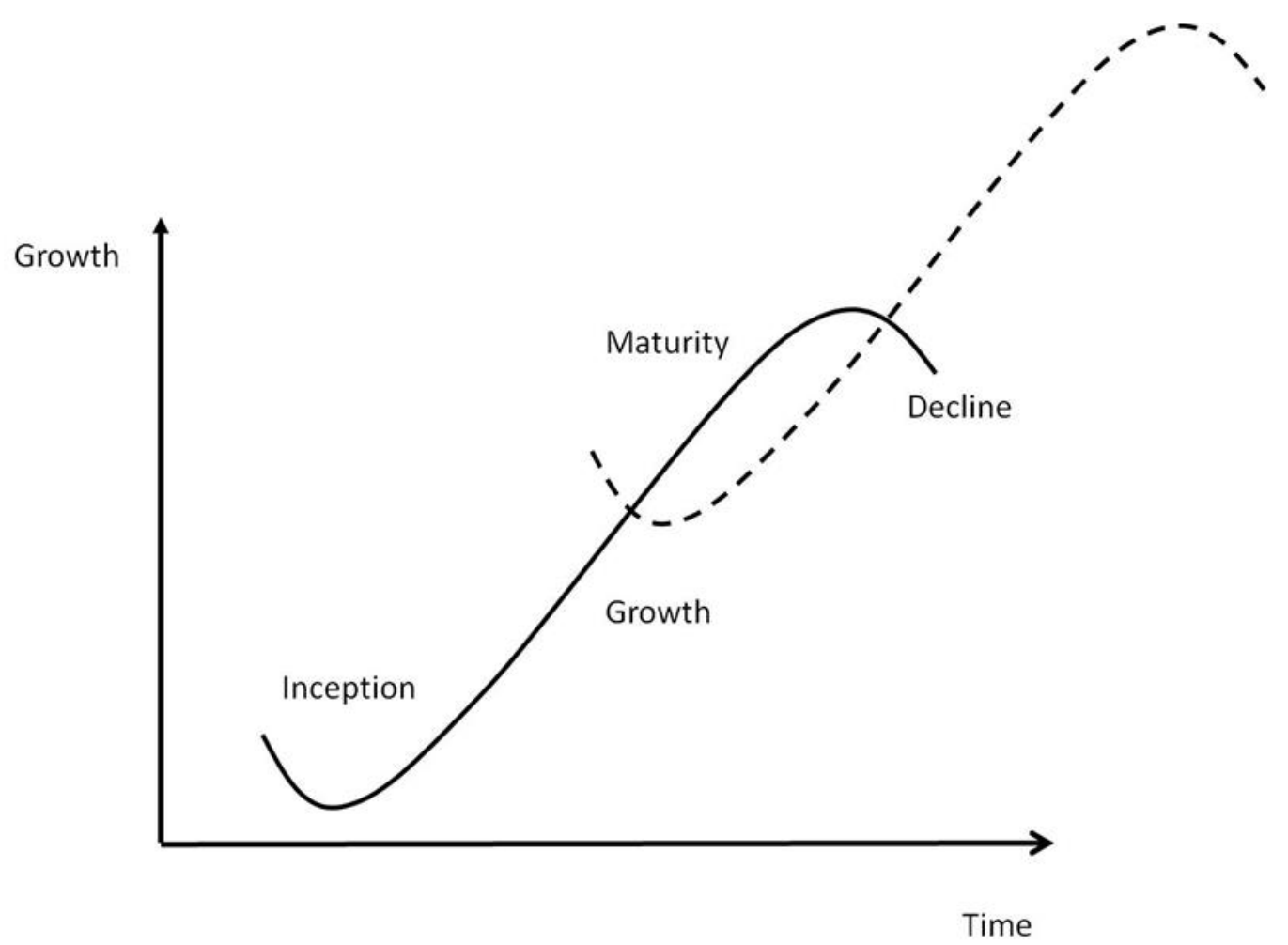

Figure 6. The sigmoid curve resultant from rekindling an Adventist missionary movement ethos 


\section{Recommendations}

A positive outlook on current contextual changes implies seeing them as opportunities to be faithful to God's purposes for His people and engage in His mission. Hirsch suggests that "the twenty-first century is turning out to be a highly complex phenomenon ... [and] the church as we know it faces a very significant adaptive challenge."47 That is also true for the Adventist Church in Brazil. Thus, as Adventists in Brazil seek to be faithful to God's mission in the twenty-first century rekindling a movement ethos seems indispensable. That should be accomplished through a biblical redefinition of Christianity and the consequent development of mission methods based on basic elements of an Adventist missionary movement ethos.

\section{Mission as a Way of Being in This World}

The recovering of the centrality of mission in the lives of God's people is fundamental to fostering an Adventist missionary movement that displays vitality during times of change. Greenleaf pointed out that during challenging times, such as the Great Depression, the church was able to respond to its context.

In spite of economic problems and nationalism, the church did not collapse. Probably no stronger unifying influence existed than the evangelistic purpose that constituted the church's raison d'etre. As pronounced as the materialistic tendencies became during the 1930s, they served to emphasize the virtue of the gospel commission and the ultimate goal of all workers, no matter what their personal background or what their salary and perquisites. ${ }^{48}$

\footnotetext{
${ }^{47}$ Hirsch, The Forgotten Ways, 16.

${ }^{48}$ Greenleaf, A Land of Hope, 307.
} 
It is essential to focus on the "compelling motivation in South America" that has guided the Adventist Church since the first pioneers arrived in the 1890s and to stress again the encompassing understanding that mission is more than an activity for the professional ministry-it is a way of being in this world. ${ }^{49}$

Such a movement will be more likely to engage the totality of the Brazilian community's socio-cultural life while being faithful to the totality of the gospel. It will empower lay members to foster the type of an Adventist missionary movement that is contextual and indigenous. ${ }^{50}$

The starting point is the understanding that mission belongs to God. Mission is "not primarily an activity of the church, but an attribute of God." ${ }^{51}$ Consequently, to participate in the movement of God's love toward people, the people of God should develop that way of being. This development also includes learning about the essential character of Christianity through the Bible, while critically analyzing historical and contemporary movements, as exemplified in chapter 2 through $4 .^{52}$

${ }^{49}$ Greenleaf, A Land of Hope, 616.

${ }^{50}$ Ruben Paredes Alfaro, "Expressions of Evangelism in Latin America," International Review of Mission 103, no. 2 (2014): 347. See the discussion in Marcelo Dias, "Ao encontro do Brasil do século 21: em busca de uma abordagem missiológica." In: Sociologia e Adventismo: Desafios brasileiros para a missão. Engenheiro Coelho, SP, Brazil: Unaspress, 2015.

${ }^{51}$ Bosch, Transforming Mission, 390. See also Tennent, Invitation to World Missions; P. Gerard Damsteegt, Foundations of the Seventh-day Adventist Message and Mission (Berrien Springs, MI: Andrews University Press, 1977), 259-263.

${ }^{52}$ For example, David Garrison, A Wind in the House of Islam (Monument, CO: WigTake, 2014); Steve Smith, T4t: A Discipleship Re-Revolution (Monument, CO: WigTake, 2011); Jerry Trousdale, Miraculous Movements: How Hundreds of Thousands of Muslims Are Falling in Love with Jesus (Nashville, TN: Thomas Nelson, 2012); Rad Zdero, Nexus: The World House Church Movement Reader (Pasadena, CA: William Carey Library, 2007); David Allen Bledsoe, Movimento Neopentecostal Brasileiro: Um Estudo de Caso (Sao Paulo, Brazil: Hagnos, 2012). 


\section{Mission Methods and a Movement Ethos}

In order to take advantage of the contextual changes and to fulfill the mission of God's people, Adventist methods will have to be developed based on biblical principles in the first place and in ways that allow the gospel message to infiltrate and to transform the local contexts. That includes the realization that no one method fits all congregations, especially in a country as large as Brazil. Those methods must foster a biblical understanding of Christianity and develop movements with a missionary ethos.

Church leaders should monitor and kindle the ethos of an Adventist movement in Brazil based on the six fundamental principles, as developed in chapters 5 and $6 .{ }^{53}$ In spite of the somewhat positive analysis of the Adventist movement ethos in Brazil, it is clear the there is much room for improvement in each area based on the review in chapters 7 and 8 . This is especially important in face of the realization of the ideal biblical standards and the current contextual changes.

\section{Christ: Savior, Lord, and Priest}

Adventists should develop the characteristics of God's remnant, including Jesus' unshakable confidence in God and the authority of Scripture. That implies that the development of mission methods should begin with deep, thorough Bible exploration. Mission methods are not prescribed in the Bible for every current context but all revelation and every principle needed to develop them are to be found in Scripture.

\footnotetext{
${ }^{53} \mathrm{An}$ example of this type of monitoring happened at the end of 1944. Division leaders observed that ministers were too caught up in institutional duties and too much effort was not invested directly to mission. A resolution was voted to promote evangelism through short campaigns, meetings in homes, and involvement by the laymen. Greenleaf, The Seventh-day Adventist Church in Latin America and the Caribbean, 2:198.
} 
Related to that is the distinctive and enriching aspects of Adventist theology, which are often emphasized in mission methods. In a culture with traces of orality and lower levels of literacy, more balanced methods that include the cognitive, affective, and evaluative dimensions of peoples' worldviews are still needed. Adventist unique beliefs have to become more than just a set of doctrines. Part of the recommendation is to foster a Christocentric approach for every teaching, where Jesus remains the center to the distinctive SDA beliefs and offers a real relationship to each believer, and the church continues the preaching, teaching, and healing of Jesus. ${ }^{54}$

The Adventist prophetic understanding, for example, should be translated into more than cluttered and complicated theologies that become obstacles to those who approach the church and that sometimes give members a vague sense of identity disconnected from their lives. The comprehension about God's priestly ministry in heaven during the time of the end should foster a relationship of fear, trust, and joy for Adventists. The Great Controversy belief should also give a strong basis for a nondualistic spirituality, that develops an all-of-life perspective to faith, and that fosters an ethos that takes into consideration the interaction between God, the church, and the world. It seems that sometimes the Adventist heavy emphasis on keeping the Sabbath results in a dualistic spirituality, which leads to a practical polytheism. People have one identity on Sabbath and a different one during the rest of the week. All the following aspects of the ethos depend on this biblical understanding about God.

\footnotetext{
${ }^{54}$ Sarli has pointed out the negative effects of a legalistic preaching and the need for "a more Christ-Centered message" in a study concluded in 1980. Joel Sarli, "A Study of the Growth of the Seventhday Adventist Church in the Metropolitan Area of Sao Paulo, Brazil" (DMin diss., Andrews University, December 1980).
} 


\section{Missional-Incarnational Impulse of the Coming of Jesus}

In order to rekindle the motivation that comes from the assurance of the imminent return of Jesus, the blessed hope of the church, and the grand climax of the gospel, it is important to foster a way of being in this world characterized by continual expectancy, urgency, and watchfulness. There is need of a readiness that is not passive but rather responsibly active.

Adventist pastors in Brazil should be equipped to be intentional in the contextualization of their strategies. That would place a heavy emphasis on being dedicated to learning the local context and the people's worldviews as part of the process of preparation for mission and the transmission of the gospel.

The realization that people are increasingly resistant and repulsed by organized religion should be a warning that the churches' dependence on methods and strategies focused on attracting people to the churches will limit the possibilities of evangelization. It is time to balance the Adventist ecclesiastical understanding by applying the incarnational principle and emphasizing the need for the people of God to be present, near, and part of their community. ADRA community projects, Adventist education initiatives, healthful living awareness, Pathfinders, and Adventurers have much potential for helping that way of living to become a reality.

A missiological understanding about critical contextualization reveals that the intent is not to waterdown the message or to conform to the receptors' agenda but to preserve the essence of the gospel and avoid high-levels of syncretism. Preservation of biblical truth has been an important part of the Adventist movement identity from the beginning. 
In order for that to become a reality, mission methods must take into consideration the people group concept and research about unreached ethnic groups, subcultures, and urban tribes. Read's 50-year-old study about patterns of church growth in Brazil, despite acknowledging its limitations, summarizes favorable social characteristics that should be taken into consideration: racial endowment, emotional nature, Spiritist influence, illiteracy, miraculous and mystic elements, and peaceful and family-loving people. ${ }^{55}$ Besides focusing on the most receptive people and the unreached areas, Adventist strategies should also contemplate those people groups that have not had contact with the gospel. Some obvious groups that should be part of such plans include indigenous peoples ${ }^{56}$ urban tribes, Spiritists, African religionists, and diaspora groups (Lebanese, Japanese, Arabs, Haitians, etc.). ${ }^{57}$

\section{Apostolic Environment within the Great Controversy}

As the missional ethos of the movement is rekindled there is a need to have leaders that are mission-minded, have an apostolic passion, and are able to instill that passion in church members. ${ }^{58}$ Such leadership is less based on personality and charisma,

${ }^{55}$ Read, New Patterns of Church Growth in Brazil, 208-213.

${ }^{56}$ Only 58 languages have some portion of the Bible. Ronaldo Lidorio, "Mission among Indigenous Groups in Brazil: Lessons, Challenges, and Opportunities," Lausanne Global Analysis 3, no. 1 (2014): 7, 12 .

${ }^{57}$ Brazil has the largest population of Italian origin outside Italy, the largest Japanese population outside Japan, the largest Arab population outside the Middle East, and the second largest German population outside Germany. See also Kleber Goncalves, "A Critique of the Urban Mission of the Church in the Light of an Emerging Postmodern Condition” (PhD diss., Andrews University, 2005).

${ }^{58}$ Sarli has concluded in his study that "the SDA Church in Sao Paulo must use all the resources of the lay activities to reach the people," 3 . 
and more based on faithfulness to the biblical vision, engagement with the stewardship of God's mission, and the mobilization of God's people. Such leaders are especially interested in the formation of new leaders found both in the denominational ranks and in the local congregations. ${ }^{59}$

Missional leadership would also be a spiritual-gifted leadership that recognizes every believer's empowerment for witnessing and the role of basic spiritual gifts (Eph 4:7-11: apostles, evangelists, prophets, and pastor-teachers). It would foster a healthy relationship between itinerant evangelists and local witnessing by Adventist communities, which is the result of a better understanding of public, mass evangelization, and group conversion. By avoiding the professionalization of mission, laity can be responsible for any and every part of the disciple-making process, from spreading the seed to harvesting.

Offering mission training programs for lay leaders and classes both at the undergraduate and graduate levels in ministerial programs is an essential need. If those opportunities are accompanied by real missionary experiences in the field, local or overseas, short or long term, the results would be maximized.

\section{Spiritual Organic Systems}

Every part of a missionary movement must have a clear missionary focus. The continuous assessment of the role of every institution and the need to study the most effective organizational structure to support a missionary movement is essential.

\footnotetext{
${ }^{59}$ See also Marcelo Dias, "The Concept of Vision: From a Broader Comprehension to a Better Application in Ministry." In The Book and the Student: Theological Education as Mission, ed. Wagner Kuhn, 313-338. Berrien Springs, MI: Department of World Mission, 2012.
} 
Discussions should go beyond the proposals to eliminate one or two levels of the administration to finding alternatives to the pyramidal organogram of the church. ${ }^{60}$

While a noninstitutional movement is not an alternative, organic systems of networks could inspire new models of structures that are better at survival, adaptation, and reproduction. These models should be simple and rely on decentralized authority, dynamic decision processes, and contextualized approaches.

Organic structures should interconnect different parts of the movement, demand well-trained professionals to manage institutions, and dedicated mission-minded pastors for the local congregations, which is the most vital element of the structure. Local leaders would have the responsibility of being faithful to the movement's mission and developing local outreach plans since the priority for the use of resources, including finances, would be focused on missionary fronts. Specific mission structures, one of the most important contributions at the macro level, should be developed to provide ways for people to engage in worldwide mission. After all, the structure of the Adventist movement in Brazil should allow for spontaneous and hyperbolic development.

\section{Community for God}

In times of growing skepticism toward organized religion, the Adventist movement in Brazil should develop a sense of community that more faithfully embodies God's empowering presence through the Holy Spirit and His eternal gospel. The remnant-claimed identity should be witnessed through the fostering of the values of the Kingdom of God such as a sense of justice, goodness, beauty, and truth among believers

\footnotetext{
${ }^{60}$ See also Marcelo E. C. Dias, “Estrutura da Igreja,” Revista Adventista, July, 2013, 18-19.
} 
and toward those who do not belong to their faith. A way of living that truly reflects the keeping of God's commandments and the faith of Jesus would confirm that this movement's self-understanding is based on the revelation God has entrusted to it and is not restricted to its belief statement. This would also foster unity within the movement that comes from a common mission, not only common beliefs. ${ }^{61}$

The experience of Christian togetherness should not simply be for the benefit of those who are part of the Adventist community as it seeks to embrace all humanity including the public. Sabbath should be at the center of this experience as the special day to develop a kind of community based on relationships with God and with others. As Adventists live out different aspects of their doctrines, especially the Sabbath, they must also fight the bubble effect resulting from an exclusivist attitude. This would reinforce the movement's role as part of the people of God and the universal church by taking part in worldwide worship and witness that helps vindicate God's character before the universe.

\section{Disciple-making for Eternity}

Finally, at the core of the movement there has to be a disciple-making process, usually more cyclical than linear, moving people from non-believers to disciplers. This disciple-making process has to begin before conversion and involve much more than baptism as one grows toward spiritual maturity.

The process' goal is full allegiance to Christ and engagement through community service and mission involvement. It cannot be assumed through church attendance as it

\footnotetext{
${ }^{61}$ Sarli found in his research that "the social forces of the SDA Church helped the new converts to find a new community to replace the rural or small-village communities they left when they migrated to the city." "A Study of the Growth of the Seventh-day Adventist Church," 2.
} 
has to include Scripture teaching, journeying together, worshiping God with all one's life, caring for the unreached, mobilizing people, and being a witness in every way. This is a learning process that connects cognitive, affective, and practical dimensions.

An Adventist understanding of the preparation for Christ's second coming involves life transformation in all the different spheres of relationships: with God, family, church, and world. Everyone should develop a life of total surrender that can persevere, if needed, through persecution and death.

Consequently, success metrics have to be based on the transformation of lives by the power of the gospel. The vitality of the Adventist movement should be assessed based on more than number of baptisms, planted churches, tithe paying, offerings, church attendance, and avoidance of certain destructive behaviors. ${ }^{62}$

When the church thinks it's the destination, it also confuses the scorecard. It thinks that if people are hovering around and in the church, the church is winning. The truth is, when that's the case, the church is really keeping people from where they want to go, from their real destination. The destination is life. ${ }^{63}$

Thurston, one of the pioneers of the Adventist movement in Brazil, once expressed his spiritual understanding of mission, "It is not the number of churches which we may be able to report that rejoices our hearts so much as to see so many turning from sin to righteousness. ${ }^{.64}$

\footnotetext{
${ }^{62}$ Pierson, The Dynamics of Christian Mission, 301. Greenleaf suggests that the source of ministerial income was the underlying cause for pastors to see "their successes in terms of baptisms, formation of congregations, and evangelism leading directly to church membership." Greenleaf, The Seventh-day Adventist Church in Latin America and the Caribbean, 1:21. A very popular approach to assess the health of local congregations is Christian Schwarz' Natural Church Development study.

${ }^{63}$ Reggie McNeal, Missional Renaissance: Changing the Scorecard for the Church, 1st ed. (San Francisco, CA: Jossey-Bass, 2009), 16.

${ }^{64}$ Thurston, “A Trip to Southern Brazil," 12.
} 


\section{A Missionary-Sending Movement}

A sign that the Adventist movement in Brazil has developed a true Christian ethos would be its significant missionary-sending activity to the world. That mature missiological understanding would do away with the geographic myth that "we evangelize here and do mission there" and replace ethnocentrism with a strong commitment to global missionary responsibility. ${ }^{65}$

No clear date marks the break between the time when the South American church was more or less a 'foreign mission field' and when it became a partner in the global organization of Adventism. This change becomes quite visible during the 1940s when South American names begin to appear more prominently in church records. The weight of North America remains after 1940, but South American influence progressively assumes more importance and becomes the prevailing story in the later chapters. From my study I conclude that by 1980 the transition was complete. ${ }^{66}$

In 2010, 400,000 international missionaries were sent by all Christian denominations (not counting those working in their home countries). Three of the ten countries sending the most missionaries were from the majority world: Brazil, South Korea, and India. South Africa, the Philippines, Mexico, China, Colombia, and Nigeria were also among the top twenty sending countries. In 2010, 34,000 (70\% more than in 2000) missionaries were sent from Brazil. There is a growing trend. Majority world missionaries often have a greater understanding of the need for mission and social justice to go hand-in-hand, especially to fight poverty and hunger. In Brazil, this trend is connected with more responsibility for world evangelization, economic stabilization, language acquisition by young people, and the Christian ethos in Latin America.

\footnotetext{
${ }^{65}$ Hirsch, The Forgotten Ways, 130.

${ }^{66}$ Greenleaf, A Land of Hope, 11.
} 
However, the majority of missionaries is still Catholic and their main destination is the United States. ${ }^{67}$

Although the South American Division has taken steps in the direction of becoming a missionary-sending movement during the last five years, ${ }^{68}$ there is much more to be done. As Erton Kohler, South American Division president, stated during his final remarks at the I Will Go 2015 Youth Congress at Universitario Adventista de Sao Paulo-Engenheiro Coelho, after considering the current large mobilization of young people in outreach projects, even if we knew that everyone had heard the message here in Brazil, we would still have much of the world to evangelize. ${ }^{69}$

It is time to embrace the Adventist hope as it faces the daunting missionary challenges of the end times. William Johnsson warns that "we Adventists have been at it for more than 160 years and barely made a dent." ${ }^{70}$ As time draws closer to the second coming of Jesus, it is time to be a faithful and creative remnant that becomes an evangelistic and prophetic presence. The Adventist movement should become the catalyst that unites God's true followers of every nation, tribe, people, and language. And the

\footnotetext{
${ }^{67}$ Center for the Study of Global Christianity, Christianity in Its Global Context, 1970-2020, 8, 7678. See also Gailyn Van Rheenen, "The Changing Cultural Ethos of Latin America," Monthly Missiological Reflection, 2002, accessed January 10, 2016, www.missiology.org/mr-22-the-changingcultural-ethos-of-latin-america/

${ }^{68}$ Felipe Lemos, “Grupo de 25 Famílias É Consagrado para Missão Mundial," Agência Adventista Sul-Americana de Notícias, accessed January 10, 2016, http://noticias.adventistas.org/pt/noticia/ evangelismo-integrado/grupo-de-25-familias-e-consagrado-para-missao-mundial/. For a detailed study of Brazilian missionaries, see Wilson Roberto de Borba, "A Base Missionária Adventista do Sétimo Dia Brasileira: Sua Formação, Consolidação e Expansão" (DMin diss., UNASP-EC, 2009). According to his research before 2009, almost 70\% of the Brazilian missionaries worked in places with a solid Adventist presence.

${ }^{69}$ Erton Kohler, "I Will Go 2015 Youth Conference Speech" (concluding speech at Brazil Adventist University, Engenheiro Coelho, SP, Brazil, 12 September 2015).

${ }^{70}$ Johnsson, “Adventist Mission Today.“
} 
driving force behind that movement could come from the Brazilian Adventist missionary movement and its ethos. ${ }^{71}$

There is a great work before us. The world is to be warned. The truth is to be translated into many languages, that all nations may enjoy its pure, life-giving influence. This work calls for the exercise of all the talents that God has intrusted to our keeping, - the pen, the press, the voice, the purse, and the sanctified affections of the soul. Christ has made us ambassadors to make known his salvation to the children of men; and if we are clothed with the righteousness of Christ and are filled with the joy of his indwelling Spirit, we shall not be able to hold our peace. The truth will be poured forth from hearts all aglow with the love of God. ${ }^{72}$

${ }^{71}$ As Pierson noted in 2009 in his only reference to the Adventist Church in Brazil, the Adventist membership was already larger than its mother church in the United States. Pierson, The Dynamics of Christian Mission, 299.

${ }^{72}$ Ellen G. White, “The Foreigners in America," Review and Herald, October 29, 1914. 


\section{BIBLIOGRAPHY}

“Acts 2000 Impacts Brazil.” Adventist Review, September, 1999.

Adams, R. E. “Na União Este-Brasileira.” Revista Adventista, September, 1950.

. "Lay Preachers to the Front in East Brazil." Review and Herald, October 8, 1953.

. "Laymen Win Hundreds in South Brazil." Review and Herald, August 10, 1961.

Addison, Steve. Movements That Change the World. Rev. ed. Smyrna, DE: Missional Press, 2009.

“Additional Facts on Brazil's Middle Class." Accessed October 8, 2015. http://www .brasil.gov.br/para/press/press-releases/august-1/brazils-middle-class-innumbers/br_model1?set_language=en.

“Adiós to Poverty, Hola to Consumption.” The Economist, August 16, 2007.

Alfaro, Ruben Paredes. "Expressions of Evangelism in Latin America." International Review of Mission 103, no. 2 (2014).

Almeida, Edgar V. "Como Conheci a Igreja Adventista.” Revista Adventista, August 1945.

“Amigos Para Sempre.” Revista Adventista, May, 1985.

“APS Promove Encontros de Treinamento.” Revista Adventista, November, 1996.

Araujo, Alex. "Globalization and World Evangelism.” In Global Missiology for the 21st Century: The Iguassu Dialogue, edited by William D. Taylor, xi. Grand Rapids, MI: Baker Academic, 2000.

Arthur, David Tallmadge. “'Come out of Babylon': A Study of Millerite Separatism and Denominationalism, 1840-1865." PhD diss., The University of Rochester, 1970.

“Assembleia Mostra Crescimento na União Sul.” Revista Adventista, April, 1996. 
Audisio, Gabriel. The Waldensian Dissent: Persecution and Survival, C. 1170-C. 1570

Cambridge Medieval Textbooks. New York: Cambridge University Press, 1999.

Azevedo, Roberto C. "Brazil's Biggest Baptism.” Review and Herald, June 29, 1961, 2. $1964,2$.

."The Largest Baptism." South American Division Bulletin, April-September . "Panorama Educacional da Divisão Sul-Americana." Revista Adventista, February, 1992.

."Missão Global 2000.” Revista Adventista, March, 1995.

Baerg, J. “Boa Identificação.” Revista Adventista, September, 1945.

Bainbridge, William Sims. The Sociology of Religious Movements. New York: Routledge, 1997.

Ball, B. W. The English Connection: The Puritan Roots of Seventh-day Adventist Belief. 2nd ed. Cambridge, England: J. Clarke, 2014.

Baracat, José. "Como Atrair Mais Membros Para as Nossas Escolas Sabatinas." Revista Adventista, May 1952.

Barcelos, João A. “Escolas Sabatinas Filiais.” Revista Adventista, August, 1952.

Barna Group. "3 Trends Redefining the Information Age.” Accessed October 27, 2013. https://www.barna.org/barna-update/culture/641-3-trends-redefining-theinformation-age\#.Um2Afst3uUk.

. "How Technology Is Changing Millenial Faith.” Accessed October 27, 2013. https://www.barna.org/barna-update/millennials/640-how-technology-ischanging-millennial-faith\#.Um2IKMt3uUk.

Barreto Junior, Alfeu Olival, and Idemburgo Pereira Frazão Felix. "Identidades: No Enredo da Pós-Modernidade no Brasil." Revista Eletrônica do Instituto de Humanidades UNIGRANRIO 9, no. 33 (2010): 1-16.

Bauer, Bruce L. "Congregational and Mission Structures and How the Seventh-day Adventist Church Has Related to Them." DMiss diss., Fuller Theological Seminary, 1983.

Baxter, Terry. Frederick Douglass's Curious Audiences: Ethos in the Age of the Consumable Subject. Studies in Major Literary Authors. New York: Routledge, 2004. 
Beach, W. R. "God's Work Is Onward in Brazil.” Review and Herald, March 27, 1958.

Bechara, Assad. "Youth Enjoy Prisma Service." Adventist Review, October 20, 1983.

Bellofatto, Gina A., and Todd M. Johnson. "Key Findings of Christianity in Its Global Context, 1970-2020." International Bulletin of Missionary Research 37, no. 3 (2013): 8 .

Belvedere, Daniel. Revista Adventista (Argentina). May 1981, 19. Quoted in Timm, Alberto R. "Building a Growing Church: The South American Experience." Ministry Magazine, 2008.

Berger, Peter L. The Sacred Canopy: Elements of a Sociological Theory of Religion. 1st ed. Garden City, NY: Doubleday, 1967.

Beverley, John, Michael Aronna, and José Oviedo. The Postmodernism Debate in Latin America. Durham, NC: Duke University Press, 1995.

Biller, Peter. The Waldenses, 1170-1530: Between a Religious Order and a Church. Variorum Collected Studies Series. Burlington, VT: Ashgate, 2002.

Bledsoe, David Allen. Movimento Neopentecostal Brasileiro: Um Estudo De Caso. Sao Paulo, Brazil: Hagnos, 2012.

Bliss, Sylvester. Memoirs of William Miller: With Appendices Containing Three Other Contemporary Biographical Sketches. Adventist Classic Library. Berrien Springs, MI: Andrews University Press, 2005.

Blocher, Jacques A., and Jacques Blandenier. The Evangelization of the World: A History of Christian Missions. Pasadena, CA: William Carey Library, 2013.

Blumer, Herbert. Symbolic Interactionism: Perspective and Method. Englewood Cliffs, NJ: Prentice-Hall, 1969.

“Boas Novas.”Revista Adventista, January, 1948.

Bock, Lowell. "Visitor Sees Soul-Winning Activity in South America." Adventist Review, March 25, 1982.

Boehm, Harley. "Ressonância da Voz da Profecia.” Revista Adventista, July, 1945.

Bonfim, Osvaldino. "Colportagem Comemora 100 Anos na América Do Sul." Revista Adventista, April, 1992.

Bordin, Ruth B. "The Sect to Denomination Process in America: The Freewill Baptist Experience.” Church History 34, no. 1 (1965): 77-94. 
Bosch, David J. Transforming Mission: Paradigm Shifts in Theology of Mission. Maryknoll, NY: Orbis, 1991.

“Brasil Lidera Colportagem Mundial.” Revista Adventista, May, 1996.

Braun, Erlo. "Criado o Sistema Adventista de Comunicação." Revista Adventista, March, 1996.

"Brazil." The Seventh-day Adventist Encyclopedia. Hagerstown, MD: Review \& Herald, 1996. 10-11

"Brazil: Adventist Television Dramatically Expands under New License." Adventist News Network. Accessed November 2, 2014. http://news.adventist.org/allnews/news/go/2006-04-23/brazil-adventist-television-dramatically-expandsunder-new-license/.

"Brazil: Anti-Drug Campaign Mobilizes More Than 500 Youth.” Adventist News Network. Accessed November 2, 2014. http://news.adventist.org/en/all-news/ news/go/1998-08-31/brazil-anti-drug-campaign-mobilizes-more-than-500-youth/.

"Brazil: New Record for Nationwide Christmas Food Collection Initiative." Adventist News Network. Accessed November 2, 2014. http://news.adventist.org/all-news/ news/go/2007-12-17/brazil-new-record-for-nationwide-christmas-food-collectioninitiative/.

"Brazil: President Highlights Importance of Camporee to Country's Ideals." Adventist News Network. Accessed November 2, 2014. http://news.adventist.org/all-news/ news/go/2005-01-19/brazil-president-highlights-importance-of-camporee-tocountrys-ideals/.

"Brazil's Middle Class in Numbers." Accessed October 8, 2015. http://www.brasil .gov.br/para/press/press-releases/august-1/brazils-middle-class-in-numbers/ br_model1?set_language=en.

Brodersen, P. E. "Report of the South American Division." Review and Herald, June 6, 1926.

Brooks, James A. Mark. The New American Commentary. Nashville, TN: Broadman \& Holman, 1991.

Brown, J. L. "The Radio in South America." Review and Herald, August 9, 1934.

Bruce, F. F. The Spreading Flame: The Rise and Progress of Christianity. Grand Rapids, MI: W. B. Eerdmans, 1953. 
Bull, Malcolm, and Keith Lockhart. Seeking a Sanctuary: Seventh-day Adventism and the American Dream. 2nd ed. Bloomington, IN: Indiana University Press, 2007.

Bullon, Alejandro. “A Alegria De Testemunhar.” Revista Adventista, June, 1991. . “Gente Muda Gente.” Revista Adventista, March, 1991.

. “Missão ou Missão Global?” Revista Adventista, December, 1992.

. "O Sol da Aurora Eterna Já Desponta no Horizonte." Revista Adventista, December, 1990. . “Sai da Tua Terra...” Revista Adventista, November, 1991.

Butler, W. A. "Progress in South America." Review and Herald, July 14, 1938.

"A Cada Dez Turistas Brasileiros, Apenas Um Viaja Para o Exterior." Accessed January 10, 2016. http://www.brasil.gov.br/para/press/press-releases/august-1/brazilsmiddle-class-in-numbers/br_model1?set_language=en.

Calvert, Peter. "Latin America: An Introduction." In South America, Central America, Caribbean 2003. London, UK: Europa Publications, 2002.

Cameron, Euan. Waldenses: Rejections of Holy Church in Medieval Europe. Malden, MA: Blackwell Publishers, 2000.

“Campal Reúne Dez Mil Jovens.” Revista Adventista, August, 1996.

“Campal Reúne 3.500 Jovens na Cidade de Bauru.” Revista Adventista, August, 1988.

Campolongo, Alcides. Evangelismo, Minha Paixão. Tatuí, SP: Casa Publicadora Brasileira, 2009.

. "Grandes Concentrações da 'Voz da Profecia' e 'Fé Para Hoje' no Estado de São Paulo.” Revista Adventista, July, 1967.

. "Hundreds Respond to São Paulo Evangelism." Review and Herald, February $15,1968,2$. 1968.

Carter, R. M. "Manuel—a Brazilian Colpoteur." Review and Herald, April 12, 1917.

Castellani, Oscar. "O Nordeste e a Voz da Profecia." Revista Adventista, January, 1945. 
Center for the Study of Global Christianity. Christianity in Its Global Context, 19702020: Society, Religion, and Mission. South Hamilton, MA: Gordon Conwell Theological Seminary, 2013.

Chadwick, Henry. The Early Church. The Pelican History of the Church. Vol. 1. London: Penguin, 1967.

Chadwick, L. C. "Travels in South America." General Conference Daily Bulletin. February 6, 1893.

Chang, Curtis. Engaging Unbelief: A Captivating Strategy from Augustine \& Aquinas. Downers Grove, IL: InterVarsity Press, 2000.

Chisum, W. Jerry, and Brent E. Turvey. Crime Reconstruction. 2nd ed. Burlington, MA: Academic Press, 2011.

Coelho, Américo R. “A Voz da Profecia.” Revista Adventista, February 1945.

Cohen, G. A. "Where the Action Is: On the Site of Distributive Justice." Philosophy and Public Affairs, no. 26 (1997), p. 3-30

Cohen, Robin, and Shirin Rai. Global Social Movements. New York: Athlone Press, 2000 .

“Colportagem e Voz da Profecia Fazem Sucesso.” Revista Adventista, September, 1969.

Communication Department, General Conference of Seventh-day Adventist. Statements, Guidelines \& Other Documents. 4th exp. ed. Hagerstown, MD: Review and Herald, 2010.

“Como Lidar Com os Jovens.” Revista Adventista, June, 1987.

“Como nos Dias de Israel.” Revista Adventista, June, 1984.

“Congressão Leva a Ipatinga Mais de 2 Mil Jovens.” Revista Adventista, August, 1988.

“Congresso Reúne 5.000 Jovens.” Revista Adventista, January, 1990.

Conradi, L. R. "In South America." Review and Herald, March 9, 1911.

“Construction at 'Savage Fire’ Hospital.” Adventist Review, January 14, 1982.

Costa, Nancy, and Michele Stotz. "Caravan of Hope in Peru." Adventist Review (World Edition), October, 2005. 
Costa, Williams, Jr. "Está Escrito: 10 Anos no Brasil.” Revista Adventista, November, 2001. “

Coutinho, Eduardo F. "Postmodernism in Brazil." In International Postmodernism: Theory and Literary Practice, edited by Johannes Willem Bertens and Douwe Wessel Fokkema, pp. 327-334. Philadelphia, PA: John Benjamins, 1997.

“Crescimento e Desafios.” Revista Adventista, November, 1981.

Crossley, Nick. Making Sense of Social Movements. Philadelphia, PA: Open University Press, 2002.

da Silva, Domingos P. "Brazil Army Helps Give Medical Cadet Training." Review and Herald, July 19, 1956, p. 19.

Dabrowski, Ray. "Brazilian Youth Write Out Three-Kilometer-Long Bible in 25 Minutes." Adventist News Network, October 11, 1999, Accessed February 29, 2016, http://news.adventist.org/en/all-news/news/go/1999-10-11/brazilian-youthwrite-out-three-kilometers-long-bible-in-25-minutes/

Damsteegt, P. Gerard. Foundations of the Seventh-day Adventist Message and Mission. Berrien Springs, MI: Andrews University Press, 1977.

Dawson, C. A., and Warner E. Gettys. An Introduction to Sociology. Rev. ed. New York: Ronald Press, 1935.

de Assunção, S. Bacelar. "O Que a Voz da Profecia Pode Fazer.” Revista Adventista, May, 1958.

de Borba, Wilson Roberto. "A Base Missionária Adventista Do Sétimo Dia Brasileira: Sua Formação, Consolidação E Expansão.” DMin diss., Unasp-EC, 2009.

de Castro, Marcus Faro, and Gilberto Marcos Antonio Rodrigues. "Brazil." In Diversity and Unity in Federal Countries, edited by Luis Moreno and César Colino, pp. 76108. Canada: McGill-Queen's University Press, 2010.

de Morais, Carlos Augusto. "Notícias de Angola." Revista Adventista, October, 1953.

de Oliveira, Enoch. “O Desafio de 1968.” Revista Adventista, November, 1967.

. “Dispersão, Penetração e Explosão.” Revista Adventista, January, 1977.

. "The Lord at Work." Adventist Review, April 27, 1980, 26.

de Oliveira, Ivacy. "História dos Livros Didáticos Adventistas no Brasil.” In A Educação Adventista No Brasil. Engenheiro Coelho, SP, Brazil: Unaspress, 2004, 109-118. 
Dederen, Raoul. "The Church.” In Handbook of Seventh-day Adventist Theology, 12. Hagerstown, MD: Review and Herald, 2001.

Dias, Marcelo E. C. "The Concept of Vision: From a Broader Comprehension to a Better Application in Ministry. " In The Book and the Student: Theological Education as Mission, edited by Wagner Kuhn, 313-338. Berrien Springs, MI: Department of World Mission, 2012.

. "Ao encontro do Brasil do século 21: em busca de uma abordagem missiológica." In Sociologia e Adventismo: Desafios brasileiros para a missão. Engenheiro Coelho, SP, Brazil: Unaspress, 2015.

. "Estrutura da Igreja." Revista Adventista, July, 2013.

Dick, Everett, and Gary Land. William Miller and the Advent Crisis, 1831-1844. Berrien Springs, MI: Andrews University Press, 1994.

“Difusão: Após 10 Anos.” Revista Adventista, May, 1985.

Donkor, Kwabena, Ellen G. White Encyclopedia. Hagerstown, MD: Review and Herald, 2013.

dos Passos, J. R. “Associação Paraná-Santa Catarina.” Revista Adventista, September, 1945.

Drane, John William. Introducing the New Testament. Completely rev. and updated ed. Oxford, UK: Lion Publishing, 2000.

Drucker, Peter F. Managing in a Time of Great Change The Drucker Library. Boston, MA: Harvard Business Press, 2009.

Dunn, James D. G. Beginning from Jerusalem. Christianity in the Making. Grand Rapids, MI: W. B. Eerdmans, 2008.

Eakin, Marshall C. Brazil: The Once and Future Country. 1st ed. New York: St. Martin's Press, 1997.

Ebinger, G. F. “A Voz da Profecia Na Missão Baiana.” Revista Adventista, October, 1944.

Edersheim, Alfred. The Life and Times of Jesus the Messiah. Vol. 1. Bellingham, WA: Logos Bible Software, 1896.

Edwards, J. Ernest. "Evangelism by Truck in Rio.” Review and Herald, July 15, 1948. . “Operação ‘a Bíblia Fala.”” Revista Adventista, March, 1968. 
. "South American Evangelistic Crusade." Review and Herald, February 28, 1957.

. "South Brazil Distributes One Million Tracts." Review and Herald, July 20, 1961.

Ehlers, Waldemar. "Conferência Der Santa Catharina-Paraná.” Revista Mensal, August, 1909.

Elwell, Walter A., and Barry J. Beitzel. Baker Encyclopedia of the Bible. 2 vols. Grand Rapids, MI: Baker Book House, 1988.

“Empresários Querem Participar Mais.” Revista Adventista, March, 1992.

“Encontro Sorriso Reúne Sete Mil No Tarumã.” Revista Adventista, January, 1990.

“Encorajamento e Desafio.” Revista Adventista, May, 1997.

Enéas, Jael. “A Semente Germinou.” Revista Adventista, May, 2003.

. "Vitrine Evangelística.” Revista Adventista, July, 2002.

Escobar, Samuel. "The Global Scenario at the Turn of the Century." In Global

Missiology for the 21st Century: The Iguassu Dialogue, edited by William D.

Taylor, xi. Grand Rapids, MI: Baker Academic, 2000.

“Está Escrito.” Revista Adventista, November, 1993.

"Está Escrito.” Revista Adventista, May, 1994.

"Está Escrito Makes a Breakthrough in Central and South America." Adventist Review, June 11, 1998.

“Evangelismo 2000.” Revista Adventista, December, 1999.

“Evangelismo Acelerado.” Revista Adventista, May, 1985.

“Evangelismo Integrado.” Revista Adventista, July, 1999.

Evans, G. R. The Roots of the Reformation: Tradition, Emergence and Rupture. Downers Grove, IL: IVP Academic, 2012.

“Eventos Movimentam a Igreja em Mato Grosso.” Revista Adventista, August, 1988.

Ferraz, Itanel. "Passos que Antecedem uma Série de Conferências." Revista Adventista, September, 1968. 
Feyerabend, Henry. "New Voice of Prophecy Studies in Brazil." Review and Herald, May 7, 1964.

“Finalmente, um Programa Nacional de Televisão.” Revista Adventista, October, 1991.

“Finalmente, Surge uma Boa Idéia.” Revista Adventista, December, 1991.

"For the Record." Adventist Review, March 8, 1984, 23.

Fortin, Denis. "Nineteenth-Century Evangelicalism and the Adventist Statements of Beliefs.” Andrews University Seminary Studies 36, no. 1 (1998): 17.

Fortin, Denis, and Jerry Moon, eds. Ellen G. White Encyclopedia. Hagerstown, MD: Review and Herald, 2013.

France, R. T. The Gospel of Mark: A Commentary on the Greek Text. New International Greek Testament Commentary. Grand Rapids, MI: W. B. Eerdmans, 2002.

Frost, Michael, and Alan Hirsch. The Shaping of Things to Come: Innovation and Mission for the 21st-Century Church. Peabody, MA: Hendrickson Publishers, 2003.

Fulton, Arthur. "Argentina.” Review and Herald, July 18, 1907.

Gabara, Esther. Errant Modernism: The Ethos of Photography in Mexico and Brazil. Durham, NC: Duke University Press, 2008.

Garcia, Jeronimo G. "Series de Conferências Relâmpago.” Revista Adventista, May, 1955.

Garcia, Milton Peverini. Vida de Braulio Pérez Marcio Fundador de La Voz de La Esperanza: De Incrédulo a Campeón Del Evangelio. Nampa, ID: Pacific Press, 2007.

Garrison, David. A Wind in the House of Islam. Monument, CO: WigTake, 2014.

Geertz, Clifford. The Interpretation of Cultures: Selected Essays. New York: Basic Books, 1973.

General Conference of Seventh-day Adventists. Annual Statistical Report (1974).

Takoma Park, MD: General Conference of Seventh-day Adventists, 1975.

. Annual Statistical Report (2014). Silver Spring, MD: General Conference of Seventh-day Adventists, 2015. 
."Roadmap for Mission." In Statements, Guidelines \& Other Documents.

Edited by Communication Department, General Conference. Hagerstown, MD: Review and Herald, 2010.

Gerhardsson, Birger. The Ethos of the Bible. Philadelphia, PA: Fortress Press, 1981.

Gerlach, Luther P., and Virginia H. Hine. People, Power, Change: Movements of Social Transformation. Indianapolis, IN: Bobbs-Merrill, 1970.

Global Missiology for the 21st Century: The Iguassu Dialogue. Grand Rapids, MI: Baker Academic, 2000.

Goncalves, Kleber. "A Critique of the Urban Mission of the Church in the Light of an Emerging Postmodern Condition" PhD Diss., Seventh-day Adventist Theological Seminary, Andrews University, 2005.

González, Ondina E., and Justo L. González. Christianity in Latin America: A History. New York: Cambridge University Press, 2008.

Goodwin, Jeff, and James M. Jasper. The Social Movements Reader: Cases and Concepts. 2nd ed. Blackwell Readers in Sociology. Malden, MA: WileyBlackwell, 2009.

Goppelt, Leonhard. Theology of the New Testament. Vol. 2. Grand Rapids, MI: W. B. Eerdmans, 1982.

Graf, H. F. "Brazil.” Review and Herald, February 9, 1897.

Greenleaf, Floyd. A Land of Hope: The Growth of the Seventh-day Adventist Church in South America. Tatui, SP, Brazil: Casa Publicadora Brasileira, 2011. . The Seventh-day Adventist Church in Latin America and the Caribbean. 2 vols. Berrien Springs, MI: Andrews University Press, 1992.

Gregory, A. L. "Brazil.” Review and Herald, July 14, 1904, 1. . "Brazil." Review and Herald, January 4, 1906, 1. . "Dentists as Missionaries." Review and Herald, August 31, 1905, 1.

Grenz, Stanley J. A Primer on Postmodernism. Grand Rapids, MI: W. B. Eerdmans, 1996.

Guarda, Marcio Dias. “The Caravan of Power Yields Pentecostal Results.” Ministry, March, 2004, 13, 19. 
Haefft, Henry. "Missionaries on Their Way to Brazil.” Review and Herald, February 26, 1914.

Halliwell, Leo B. “As Atividades da Lancha “Luzeiro.” Revista Adventista, June, 1941.

. Light Bearer to the Amazon: Thrilling Stories of Missionary Labors.

Nashville, TN: Southern Pub. Association, 1945.

. Light in the Jungle: The Thirty Years' Mission of Leo and Jessie Halliwell

Along the Amazon. New York: David McKay, 1959.

Hanciles, Jehu J. "Migration and Mission: Some Implications for the Twenty-FirstCentury Church.” International Bulletin of Missionary Research 27, no. 4 (2003): 146-153.

Harder, A. C. “Rio-Espirito Santo Mission.” Review and Herald, November 7, 1946.

Harder, Palmer. "A Seara É Grande e Poucos os Ceifeiros.” Revista Adventista, October, 1947.

Harvey, John D. "Mission in Jesus' Teaching." In Mission in the New Testament: An Evangelical Approach, edited by William J. Larkin and Joel F. Williams, 30-49. Maryknoll, NY: Orbis Books, 1998.

Hasel, Gerhard F. "Divine Judgment." In Handbook of Seventh-day Adventist Theology, edited by Raoul Dederen, 12. Hagerstown, MD: Review and Herald, 2001.

Haynes, Carlyle B. “The South American Division.” Review and Herald, June 11, 1930.

Hays, Richard B. "Mapping the Field: Approaches to New Testament Ethics." In Identity, Ethics, and Ethos in the New Testament, edited by Jan G. van der Watt, pp. 3-20. New York: Walter de Gruyter, 2006.

Hengel, Martin. Between Jesus and Paul: Studies in the Earliest History of Christianity. 1st Fortress Press ed. Philadelphia, PA: Fortress Press, 1983.

Hiebert, Paul G. Anthropological Insights for Missionaries. Grand Rapids, MI: Baker Book, 1985.

. Cultural Anthropology. Philadelphia, PA: Lippincott, 1976.

. The Gospel in Human Contexts: Anthropological Explorations for

Contemporary Missions. Grand Rapids, MI: Baker Academic, 2009.

Transforming Worldviews: An Anthropological Understanding of How People Change. Grand Rapids, MI: Baker Academic, 2008. 
Hill, Jonathan. Christianity: How a Despised Sect of a Minority Religion Came to Dominate the Roman Empire. Minneapolis, MN: Fortress Press, 2011.

Hirsch, Alan. The Forgotten Ways: Reactivating the Missional Church. Grand Rapids, MI: Brazos Press, 2006.

Hirsch, Alan, and Darryn Altclass. The Forgotten Ways Handbook: A Practical Guide for Developing Missional Churches. Grand Rapids, MI: Brazos Press, 2009.

Hoelzle, Emilio. “Conferência do Rio Claro.” Revista Mensal, July, 1908.

Hofstede, Geert H. Culture's Consequences: Comparing Values, Behaviors, Institutions, and Organizations across Nations. 2nd ed. Thousand Oaks, CA: Sage Publications, 2001.

Holman Illustrated Bible Dictionary. Edited by Charles W. Draper, C. Brand, and Archie England. Nashville, TN: Holman Bible Publishers, 2003.

Hunter III, George G. The Celtic Way of Evangelism: How Christianity Can Reach the West ... Again. 10th anniversary rev. and exp. ed. Nashville, TN: Abingdon Press, 2010.

“Importantes Resoluções do Concílio de 1940 da Divisão Sul-Americana." Revista Adventista, March, 1941.

Instituto Brasileiro de Geografia e Estatística. "2010 Census: Number of Catholics Falls and Number of Protestants, Spiritists, and Persons without Religion Records Increase.” Accessed January 10, 2016. http://saladeimprensa.ibge.gov.br/ noticias.html?view=noticia\&id=1\&idnoticia $=2194 \&$ busca $=1 \& \mathrm{t}=$ censo-2010populacao-indigena-896-9-mil-tem-305-etnias-fala-274.

. “Censo 2010: População Indígena É de 896,9 Mil, Têm 305 Etnias e Fala 274 Idiomas.” Accessed January 10, 2016. http://saladeimprensa.ibge.gov.br/ noticias.html? view=noticia\&id=1\&idnoticia $=2194 \&$ busca $=1 \& \mathrm{t}=$ censo-2010populacao-indigena-896-9-mil-tem-305-etnias-fala-274.

. Censo Demográfico 2010. Rio de Janeiro: IBGE, 2012.

. "IBGE Releases Population Estimates of Municipalities in 2014." Accessed May 28, 2014. http://saladeimprensa.ibge.gov.br/en/noticias?view=noticia\&id $=1 \&$ idnoticia=2704\&busca $=1 \& \mathrm{t}=$ ibge-releases-population-estimates-ofmunicipalities-in-2014.

Instituto Nacional de Estudos e Pesquisas Educacionais Anísio Teixeira. Censo da Educação Superior: 2010--Resumo Técnico. Brasília, Brazil: Instituto Nacional de Estudos e Pesquisas Educacionais Anísio Teixeira, 2012. 
Irvin, Dale T., and Scott Sunquist. History of the World Christian Movement. Maryknoll, NY: Orbis Books, 2001.

"Itabuna em Mira.” Revista Adventista, March, 1986.

Jenkins, Philip. The Lost History of Christianity: The Thousand-Year Golden Age of the Church in the Middle East, Africa, and Asia- and How It Died. 1st ed. New York: HarperOne, 2008.

. The Next Christendom: The Coming of Global Christianity. The Future of Christianity Trilogy. New York: Oxford University Press, 2007.

Jeremias, Joachim. Jesus and the Message of the New Testament. Fortress Classics in Biblical Studies. Minneapolis, MN: Fortress Press, 2002.

. Jesus' Promise to the Nations. Naperville, IL: Alec R. Allenson, 1958.

Johnson, J. Berger. "A Word from Brazil.” Review and Herald, January 22, 1925.

Johnsson, William G. "Adventist Mission Today: A Personal Reflection.” In Message, Mission, and Unity of the Church, edited by Ángel Manuel Rodríguez, 443-453. Silver Spring, MD: Biblical Research Institute, 2013.

. "Where Laypeople Run the Church.” Adventist Review, April 3, 1986.

Johnstone, Patrick, and Jason Mandryk. Operation World: When We Pray God Works. 21st Century ed. Waynesboro, GA: Paternoster USA, 2001.

Josephus, Flavius. Antiquities of the Jews. Accessed July 17, 2013. http://www .biblestudytools.com/history/flavius-josephus/antiquities-jews/.

Kaiser, Walter C. Mission in the Old Testament: Israel as a Light to the Nations. Grand Rapids, MI: Baker Books, 2000.

Keller, Eva. The Road to Clarity: Seventh-day Adventism in Madagascar. Contemporary Anthropology of Religion. New York: Palgrave Macmillan, 2005.

Klenk, Moritz. "New Religious Movements in Global Perspective: A Systems Theoretical Approach." Zeitschrift für junge Religionswissenschaft, no. 7 (2012): 40-58.

Knight, George R. The Apocalyptic Vision and the Neutering of Adventism. Hagerstown, MD: Review and Herald, 2008. . The Fat Lady and the Kingdom: Adventist Mission Confronts the Challenges of Institutionalism and Secularization. Boise, ID: Pacific Press, 1995. 
. A Search for Identity: The Development of Seventh-day Adventist Beliefs. Adventist Heritage Series. Hagerstown, MD: Review and Herald, 2000. . Seventh-day Adventists Answer Questions on Doctrine. Annotated ed. Adventist Classic Library. Berrien Springs, MI: Andrews University Press, 2003. William Miller and the Rise of Adventism. Nampa, ID: Pacific Press, 2010.

Knight, Jonathan. Christian Origins. New York: T \& T Clark, 2008.

Kohler, Erton. "I Will Go 2015 Conference Speech.” Brazil Adventist University. Engenheiro Coelho, SP, Brazil. 12 September 2015. Concluding Speech. . "Pequenos Grupos, Grandes Resultados." Revista Adventista, April, 2002.

Kok, Jacobus, and Cornelius J. P. Niemandt. "(Re)Discovering a Missional-Incarnational Ethos.” HTS Teologiese Studies/Theological Studies 65, no. 1 (2009): 7.

Köstenberger, Andreas J., and Peter Thomas O'Brien. Salvation to the Ends of the Earth: A Biblical Theology of Mission. New Studies in Biblical Theology. Downers Grove, IL: InterVarsity Press, 2001.

Kraft, Charles H. Anthropology for Christian Witness. Maryknoll, NY: Orbis Books, 1996.

Kuh, George D. "Ethos: Its Influence on Student Learning." Liberal Education 79, no. 4 (1993): 22-31.

Kuhn, Wagner. Christian Relief and Development: Biblical, Historical, and Contemporary Perspectives of the Holistic Gospel. Engenheiro Coelho, SP, Brazil: UNASPRESS, 2005.

Kurts, Lester R. Gods in the Global Village: The World's Religions in Sociological Perspective. Los Angeles, CA: SAGE, 2012.

Ladd, George Eldon. The Gospel of the Kingdom: Scriptural Studies in the Kingdom of God. Grand Rapids, MI: W. B. Eerdmans, 1959.

. A Theology of the New Testament. Grand Rapids, MI: W. B. Eerdmans, 1974.

Lambert, Malcolm. Medieval Heresy: Popular Movements from the Gregorian Reform to the Reformation. 3rd ed. Malden, MA: Blackwell, 2002.

Lambeth, C. E. "Programa Que Faltava.” Revista Adventista, September, 1944. 
Lange, Armin, Diethard Römheld, and Matthias Weigold, eds. Judaism and Crisis: Crisis as a Catalyst in Jewish Cultural History (Schriften des Institutum Judaicum Delitzschianum). Oakville, CT: Vandenhoeck \& Ruprecht, 2011.

LaRondelle, Hans K. "The Remnant and the Three Angels' Messages." In Handbook of Seventh-day Adventist Theology, edited by Raoul Dederen, 12. Hagerstown, MD: Review and Herald, 2001.

Latourette, Kenneth Scott. A History of Christianity. 2 vols. Rev. ed. New York: Harper \& Row, 1975.

Lee, Alfred McClung. Principles of Sociology. College Outline Series. New York: Barnes \& Noble, 1953.

Lehmann, Richard P. “The Second Coming of Jesus.” In Handbook of Seventh-day Adventist Theology, edited by Raoul Dederen, 12. Hagerstown, MD: Review and Herald, 2001.

Leitzke, Waldemar. "Movimento Que Não Para Mais.” Revista Adventista, January, 1958.

Lemos, Felipe, “Grupo de 25 Famílias É Consagrado Para Missão Mundial.” Agencia Adventista Sul-Americana de Noticias. Accessed January 10, 2016. http://www .bbc.com/portuguese/noticias/2012/03/120229_missionarios_pai.shtml.

Lemos, Francisco. "50 Anos de História.” Revista Adventista, April, 2000.

Lessa, Rubens. “Hora de Transição.” Revista Adventista, December, 2006.

“Líderes da DSA Fazem Planejamento.” Revista Adventista, January, 2007.

"Líderes do Continente Sul-Americano Têm Encontro no Chile." Revista Adventista, January, 1988.

Lidorio, Ronaldo. "Mission among Indigenous Groups in Brazil: Lessons, Challenges, and Opportunities." Lausanne Global Analysis 3, no. 1 (2014).

Lindbeck, Lylon H. "Levanta-Te, Resplandece, Porque Já Vem a Tua Luz.” Revista Adventista, Abril, 1944.

. "Membros Contribuintes e o Curso Gratuito de Bíblia." Revista Adventista, August 1945.

. “A ‘Ofensiva Aérea’ na América do Sul.” Revista Adventista, August, 1943. 
. “As Primícias da 'Voz da Profecia' na América do Sul.” Revista Adventista, February 1945.

. “O Progresso de Nossas Irradiações.” Revista Adventista, March, 1944.

. "Os Progressos da Voz da Profecia na Divisão Sul-Americana.” Revista Adventista, September, 1946.

Lipke, John. "Sao Paulo (Brazil) Mission.” Review and Herald, September 3, 1914.

. "Travels in Behalf of Brazil." Review and Herald, December 22, 1904, 1.

. "A Trip through Santa Catarina and Parana." Review and Herald, June 2, 1903. 1905.

Lobo, J. P. "New Launches for the Amazon." South American Division Bulletin, May, 1942.

Loughborough, J. N. The Great Second Advent Movement: Its Rise and Progress. Washington, DC: Review and Herald, 1905.

MacMullen, Ramsay. Christianizing the Roman Empire: (A.D. 100-400). New Haven, CT: Yale University Press, 1984.

Magan, Percy T. “South American.” The Home Missionary, II (Extra), November, 1890.

Mandryk, Jason. Operation World. 7th ed. Colorado Springs, CO: Biblica, 2010.

Marinho, Robson. "Sol-Leste Gera Classes Bíblicas e Batismos.” Revista Adventista, January, 1990.

McNeal, Reggie. Missional Renaissance: Changing the Scorecard for the Church. 1st ed. San Francisco, CA: Jossey-Bass, 2009.

Medley, Carlos. "Adventist Publishing Moving in New Directions." Review and Herald, April 23, 1987.

Meyer, David S., and Sidney G. Tarrow. The Social Movement Society: Contentious Politics for a New Century. People, Passions, and Power. Lanham, MD: Rowman \& Littlefield Publishers, 1998. 
Ministerial Association of Seventh-day Adventists. Seventh-day Adventists Believe: A Biblical Exposition of 27 Fundamental Doctrines. 2nd ed. Silver Spring, MD: Ministerial Association, General Conference of Seventh-day Adventists, 2005.

“Ministério Pessoal.” Revista Adventista, December, 1998.

“Missão Amazônia Ocidental Torna-se Associação.” Revista Adventista, February, 1991.

Moberg, David O. The Church as a Social Institution: The Sociology of American Religion. 2nd ed. Grand Rapids, MI: Baker Book House, 1984.

Moreau, A. Scott, Gary Corwin, and Gary B. McGee. Introducing World Mission: A Biblical, Historical, and Practical Survey. Grand Rapids, MI: Baker Academic, 2004.

Moreno, Pedro C. "Evangelical Churches." In Religious Freedom and Evangelization in Latin America: The Challenge of Religious Pluralism, edited by Paul E. Sigmund, vii. Maryknoll, NY: Orbis Books, 1999.

Moroz, David. "Pregando Para um Auditório de Cem Mil Pessoas." Revista Adventista, August, 1968.

Murray, W. E. "Growth of Our Radio Work in South America." Review and Herald, March 12, 1953.

. "Public Evangelism in Cachoeira, Brazil." Review and Herald, September 29, 1955.

. "The South American Division.” Review and Herald, November 6, 1952.

"Mutirão de Natal Consolida Vocação Solidária da Igreja.” Revista Adventista, January, 2006.

Myers, Allen C. The Eerdmans Bible Dictionary. Grand Rapids, MI: Eerdmans, 1987.

Nagel, Ruy. “A Força da União.” Revista Adventista, December, 2006.

. "From Small Beginnings, a Bountiful Harvest." Adventist Review, July 6, 2005.

. “Gotas da Chuva Serôdia.” Revista Adventista, March, 2000.

. “Obra de Semeadura.” Revista Adventista, September, 2001.

. "Our People on the March." Adventist Review, July 4, 2000. Accessed February 29, 2016. http://archives.adventistreview.org/2000-bulletin4/8-reportsouth-america.html. 
Neill, Stephen. Christian Missions. Baltimore, MD: Penguin Books, 1964.

Netland, Harold A. Encountering Religious Pluralism: The Challenge to Christian Faith \& Mission. Downers Grove, IL: InterVarsity Press, 2001.

Newbigin, Lesslie. The Open Secret: An Introduction to the Theology of Mission. Rev. ed. Grand Rapids, MI: W. B. Eerdmans, 1995.

“News Note.” Adventist Review, May 2, 1985, 20.

Nichol, Francis D. The Midnight Cry: A Defense of the Character and Conduct of William Miller and the Millerites, Who Mistakenly Believed That the Second Coming of Christ Would Take Place in the Year 1844. Brushton, NY: TEACH Services, 2000.

, ed. The Seventh-day Adventist Bible Commentary. Rev. ed. Vol. 6.

Washington, DC: Review and Herald, 1976-1980.

Nida, Eugene A. Understanding Latin Americans: With Special Reference to Religious Values and Movements. Pasadena, CA: William Carey Library, 1974.

Niebuhr, H. Richard. The Social Sources of Denominationalism. New York: Meridian Books, 1957.

Nigri, Moisés S. “O Departamento do Rádio da Associação Paulista dos A. S. D.” Revista Adventista, January, 1944.

. “Grandes Coisas Fez o Senhor por Nós.” Revista Adventista, May, 1966.

. "Para Que o Mundo Conheça.” Revista Adventista, March, 1971.

. "This Is the South American Division." South American Division Bulletin, April-June, 1967.

. “1967: O Melhor Ano da Divisão Sul-Americana.” Revista Adventista, July, 1968, 2.

“Noticias do Escritório da Voz da Profecia.” Revista Adventista, January, 1945.

“Nordeste Investe em Pequenos Grupos.” Revista Adventista, October, 1997.

Numbers, Ronald L., and Jonathan M. Butler. The Disappointed: Millerism and Millenarianism in the Nineteenth Century. 2nd ed. Knoxville. TN: University of Tennessee Press, 1993. 
Oliveira, Geraldo G. "Evangelizing the Heart of South America." Review and Herald, February, 27 1958, 2.

. "Relação de Programas Locais de Rádio na Associação Paulista." Revista Adventista, July, 1945.

Oliver, Barry David. "Principles for Reorganization of the Seventh-Day Adventist Administrative Structure, 1888-1903: Implications for an International Church." PhD diss., Andrews University, 1989.

Olsen, O. A. "The President's Address." General Conference Daily Bulletin, February 22, 1897.

Olson, A. V. "The Lay Preachers of Brazil." Review and Herald, January 14, 1954.

Olson, L. H. "Excerpts from the Report of the Secretary." South American Division Bulletin, January-February, 1954.

Oswald, T. L. "Lay Evangelism in South America." Review and Herald, March 27, 1958.

Ott, Craig, Stephen J. Strauss, and Timothy C. Tennent. Encountering Theology of Mission: Biblical Foundations, Historical Developments, and Contemporary Issues. Encountering Mission. Grand Rapids, MI: Baker Academic, 2010.

“Participação Jovem nos 'Mil Dias de Colheita.”” Revista Adventista, December, 1983.

“Pastor Bullón Explica Projeto Sol.” Revista Adventista, April, 1988.

Peeters, Marisa Louise. "Living with the End of Times: An Analysis of American Seventh-day Adventism.” MA thesis, University of California, San Diego, 2009.

Pereyra, Rúben. "História da Evangelização Na América Do Sul." Revista Adventista, October, 1976, 3.

"Peru: More Than 30,000 Respond to 'Caravan of Hope."” Adventist News Network. Accessed November 2, 2014. http://news.adventist.org/all-news/news/go/200506-06/peru-more-than-30000-respond-to-caravan-of-hope/.

Peverini, H. J. "Brazilian Medical Cadet Complete Course at College." Review and Herald, May 9, 1974.

Pew Research Center. "Brazil's Changing Religious Landscape.” Accessed January 10, 2016. http://www.pewforum.org/2013/07/18/brazils-changing-religiouslandscape/. 
. "Global Christainity —A Report on the Size and Distribution of the World's Christian Population.” Accessed November 13, 2013. http://www .pewforum .org/2011/12/19/global-christianity-exec/.

Pierson, Paul E. The Dynamics of Christian Mission: History through a Missiological Perspective. Pasadena, CA: William Carey International University Press, 2009.

. "Moravian Missions." In Evangelical Dictionary of World Missions, edited by A. Scott Moreau, Harold A. Netland, Charles Edward van Engen, and David Burnett, 660-661. Grand Rapids, MI: Baker Books, 2000.

"Plight of Abused Children Addressed by World Church President." Adventist News Network. Accessed November 2, 2014. http://news.adventist.org/all-news/news/ go/2003-09-01/brazil-plight-of-abused-children-addressed-by-world-churchpresident/.

Pocock, Michael, Gailyn Van Rheenen, and Douglas McConnell. The Changing Face of World Missions: Engaging Contemporary Issues and Trends. Encountering Mission. Grand Rapids, MI: Baker Academic, 2005.

Prescott, W. W. "Under South American Skies-No. 1." Review and Herald, February 17, 1916.

“Programação No Ibirapuera Será 'Espetacular Mas Não Show'.” Revista Adventista, June, 1988.

“Projeto Missionário ‘Sinais Dos Tempos'.” Revista Adventista, April, 2000.

“Projeto Revive Repete Êxito.” Revista Adventista, January, 1993.

“Projeto Sol Visa a Não-Adventistas." Revista Adventista, March, 1988.

“Propaganda e Testemunho.” Revista Adventista, June, 1988.

Rabello, Roberto. "Conferências Pela Voz da Profecia.” Revista Adventista, February, 1953.

. “A Escola Radiopostal.” Revista Adventista, July, 1945.

. "Frutos da Voz da Profecia no Brasil." Revista Adventista, July, 1947.

1952.

. "Noticias do Escritório da Voz da Profecia." Revista Adventista, September,

. “Novo Dia Para o Rádio-Evangelismo.” Revista Adventista, April, 1952. 
. "Radio and Television in Brazil." Review and Herald, November 10, 1966.

. "Uma Porta Aberta." Revista Adventista, July, 1944.

. “A Voz da Profecia." Revista Adventista, March, 1944.

Rajendran, K. "Evangelical Missiology from India." In Global Missiology for the 21st Century: The Iguassu Dialogue, edited by William D. Taylor, xi. Grand Rapids, MI: Baker Academic, 2000.

Ramos, Ana Paula. Desafio Nas Águas. Tatuí, SP, Brazil: Casa Publicadora Brasileira, 2009.

Ranzolin, Leo. "Pathfinders Nearly Double Size of Host City." Adventist Review (World Edition), April, 2005.

1 .

“22,000 Youth Gather in Sao Paulo.” Adventist Review, December 20, 1982,

. Uma Voz Dedicada a Deus: A Vida de Roberto Rabello. Tatuí, SP, Brazil:

Casa Publicadora Brasileira, 2007.

Read, William R. New Patterns of Church Growth in Brazil. Grand Rapids, MI: W. B. Eerdmans, 1965.

Reis, Osmar, and Almir Marroni. "O Ministério de Publicações e o Evangelismo Integrado.” Revista Adventista, September, 2001.

“Renovação Espiritual.” Revista Adventista, November, 1986.

Rial, Carmen. “O Brasil E a Pós-Modernidade." Revista de Ciências Humanas 10, no. 14 (1993): 127-130.

Rodriguez, Ángel Manuel. "Concluding Essay: God's End-Time Remnant and the Christian Church." In Toward a Theology of the Remnant: An Adventist Eclesiological Perspective, 212-225. Silver Spring, MD: Biblical Research Institute, 2009.

. "Oneness on the Church in Message and Mission: Its Ground." In Message, Mission, and Unity of the Church, 191. Silver Spring, MD: Biblical Research Institute, 2013.

. Toward a Theology of the Remnant: An Adventist Eclesiological Perspective. Silver Spring, MD: Biblical Research Institute, 2009. 
Rowe, David L. God's Strange Work: William Miller and the End of the World. Library of Religious Biography. Grand Rapids, MI: W. B. Eerdmans, 2008.

“Rumo à Luta.” Revista Adventista, July, 1984.

Russell, Jeffrey Burton. Dissent and Order in the Middle Ages: The Search for Legitimate Authority. Twayne's Studies in Intellectual and Cultural History. New York: Twayne Publishers, 1992.

Samovar, Larry A., Richard E. Porter, Edwin R. McDaniel, and Carolyn S. Roy. Communication between Cultures. 8th ed. Boston, MA: Cengage Learning, 2013.

Santana, Heron. "Itinerário da Fé.” Revista Adventista, November, 2005.

Santos, Jobson Dornelles. "Uso da Internet na Evangelização Adventista no Brasil." Centro Universitário Adventista de São Paulo, Campus Engenheiro Coelho, 2009.

Sarli, Joel. "A Study of the Growth of the Seventh-day Adventist Church in the Metropolitan Area of Sao Paulo, Brazil.” DMin diss., Andrews University, 1980.

Schantz, Borge. "The Development of Adventist: Contemporary Appraisal." PhD diss., Fuller Theological Seminary, 1983.

Schevani, Ardoval. "O Binômio 'Voz da Profecia' e 'Temperança' no Evangelismo do Paraná.” Revista Adventista, August, 1968.

Schilbrack, Kevin. "Religion, Models of, and Reality: Are We through with Geertz?" Journal of the American Academy of Religion 73, no. 2 (2005): 429-452.

Schmidt, Santiago. “O Fator-Homem Na Obra Do Rádio.” Revista Adventista, July, 1945. . "Lay Evangelism in the East Brazil Union.” Adventist Review, June 18, 1953. . “Novo, Poderoso e Indispensável.” Revista Adventista, May, 1945. . "Sugestão de Amigo.” Revista Adventista, March, 1947.

Schneider, C. C. "The Lay Missionary Movement in the East Brazil Union.” Review and Herald, June 21, 1934.

Schubert, G. W. "Experiences in South Brazil.” Review and Herald, February 9, 1928.

Schultz, Majken. On Studying Organizational Cultures: Diagnosis and Understanding. De Gruyter Studies in Organization. New York: W. de Gruyter, 1995. 
Schwarz, Richard W. Light Bearers to the Remnant: Denominational History Textbook for Seventh-day Adventist College Classes. Mountain View, CA: Pacific Press, 1979.

Seemuth, David P. "Mission in the Early Church." In Mission in the New Testament: An Evangelical Approach, edited by William J. Larkin and Joel F. Williams, 50-60. Maryknoll, NY: Orbis Books, 1998.

“Semana de Oração e Louvor Reúne Mais de Três Mil Jovens." Revista Adventista, August, 1988.

Seventh-day Adventist Encyclopedia. 2nd rev. ed. Hagerstown, MD: Review and Herald, 1996.

Silveira, Agax. "Telephone Plan Successful in Brazilian Cities." Review and Herald, August 14, 1980.

Siqueira, F. N. "Serving Our God and Our Country in Brazil." Review and Herald, June 9, 1955.

“Sisac Divulga Atividades.” Revista Adventista, July, 1996.

Skidmore, Thomas E. Brazil: Five Centuries of Change. 2nd ed. New York: Oxford University Press, 2010.

Skidmore, Thomas E., and Peter H. Smith. Modern Latin America. 5th ed. New York: Oxford University Press, 2001.

Skinner, Carolyn. Women Physicians and Professional Ethos in Nineteenth-Century America. Studies in Rhetorics and Feminisms. Carbondale, IL: Southern Illinois University Press, 2014.

Smith, David. "Contemporary Christianity in the Non-Western World." In Introduction to World Religions, edited by Christopher H. Partridge, 343-349. Minneapolis, MN: Fortress Press, 2005.

Smith, Steve. T4t: A Discipleship Re-Revolution. Monument, CO: WigTake, 2011.

Snow, David A., Sarah A. Soule, and Hanspeter Kriesi. "Mapping the Terrain." In The Blackwell Companion to Social Movements, 3-11. Hoboken, NJ: WileyBlackwell, 2004.

Snyder, Howard. New Wineskins: Changing the Man-Made Structures of the Church. London: Marshall, Morgan, and Scott, 1978. 
Søgaard, Viggo. Research in Church and Mission. Pasadena, CA: William Carey Library, 1996.

“Sonho Realizado." Revista Adventista, January, 1997.

"South America: Church Grows Via Bible Study Groups." Adventist News Network. November 11, 2003. Accessed February 21, 2016. http://news.adventist.org/en/ all-news/news/go/2003-11-10/south-america-church-grows-via-bible-studygroups/

"South American." Adventist Review, November 28, 1985, 28.

"South American Church Leaders Call for 'Massive Participation' in Evangelism." Adventist News Network, May 8, 2001. Accessed February 21, 2016. http://news.adventist.org/en/all-news/news/go/2001-05-07/south-americanchurch-leaders-call-for-massive-participation-in-evangelism/

Spicer, W. A. “Mexico.” The Home Missionary, V, June, 1893.

."In the United States of Brazil." Review and Herald, June 27, 1912, 2.

Spickard, Paul R., and Kevin M. Cragg. A Global History of Christians: How Everyday Believers Experienced Their World. Grand Rapids, MI: Baker Academic, 1994.

Spies, F. W. "Brazil." Review and Herald, May 25, 1897.

. "Brazil." Review and Herald, February 20, 1900.

. "Brazil." Review and Herald, April 13, 1905.

."Brazil." Review and Herald, June 15, 1905.

. "Brazil Conference." Review and Herald, August 25, 1904, 1.

. "Brazil-General Meetings." Review and Herald, November 2, 1905.

. "Brazilian Union Conference." Review and Herald, February 10, 1916.

."An Encouraging Event for Brazil.” Review and Herald, December 11, 1913.

. "Experiences in Brazil." Review and Herald, October 25, 1898.

. "General Meetings in Brazil." Review and Herald, February 4, 1904, 2.

. "Organization of the Brazil Conference." Review and Herald, October 21, 1902. 
. "Rio de Janeiro, Brazil." Review and Herald, March 22, 1906.

. "Rio Grande do Sul Conference." Review and Herald, June 4, 1914.

. "Tent Meetings in Brazil." Review and Herald, April 29, 1915.

Stark, Rodney. The Rise of Christianity: How the Obscure, Marginal Jesus Movement Became the Dominant Religious Force in the Western World in a Few Centuries. San Francisco, CA: HarperSanFrancisco, 1997.

Stauffer, A. B. "Brazil." Review and Herald, December 3, 1901.

. "Report from Argentina and Uruguay." Review and Herald, June 13, 1893.

. "Report from Brazil." Review and Herald, February 20, 1894.

Stefon, Matt. Judaism: History, Belief, and Practice. The Britannica Guide to Religion. New York: Rosen Educational Services, 2012.

Stein, William. "Our International School in Brazil." Review and Herald, April 20, 1897.

Stetzer, Ed, and Thom S. Rainer. Transformational Church: Creating a New Scorecard for Congregations. Nashville, TN: B \& H Pub., 2010.

Streithorst, Germano. “O Início da Nossa Obra.” Revista Adventista, March, 1958.

Swatos, William H., and Peter Kivisto. Encyclopedia of Religion and Society. Walnut Creek, CA: AltaMira Press, 1998.

Szalos-Farkas, Zoltan. "An Exploration of the Rise and Development of Seventh-day Adventist Spirituality: With Special Reference to the Charismatic Guidance of Ellen G. White, 1844-1915.” PhD diss., Aberdeen University, 2004.

Tang, Samuel, "People of God." Holman Illustrated Bible Dictionary. Edited by Charles W. Draper, C. Brand, and Archie England. Nashville, TN: Holman Bible Publishers, 2003.

Taylor, Harold. "Contextualized Mission in Church History." In Encountering New Religious Movements: A Holistic Evangelical Approach, edited by Irving Hexham, Stephen Rost and John Morehead, 43-60. Grand Rapids, MI: Kregel Academic \& Professional, 2004.

Tennent, Timothy C. Invitation to World Missions: A Trinitarian Missiology for the Twenty-First Century. Grand Rapids, MI: Kregel, 2010. 
Terry, John Mark, Ebbie C. Smith, and Justice Anderson. Missiology: An Introduction to the Foundations, History, and Strategies of World Missions. Nashville, TN:

Broadman \& Holman Publishers, 1998.

Thurston, W. H. "Brazil.” Review and Herald, August 13, 1895, 1.

. "Brazil." Review and Herald, January 14, 1896, 2.

. "Brazil." Review and Herald, September 29, 1896, 3.

. "Brazil." Review and Herald, December 15, 1896.

. "Brazil." Review and Herald, November 21, 1899, 2.

. "General Meeting in Brazil." Review and Herald, August 9, 1898, 1.

. "In Brazil." Review and Herald, April 23, 1901.

. "A Trip to Southern Brazil." Review and Herald, April 6, 1897.

Tieszen, Charles. "Persecuion of Christians in the World Today: Current Trends and Their Implications for the Globa Church." Lusanne Global Analysis 4, no. 2 (September 2013): 6-9. Accessed September, 2013. https://www .lausanne.org/docs/Iga/lausanne-global-analysis-2013-09.pdf.

Timm, Alberto R. "Building a Growing Church: The South American Experience." Ministry, October 2008, 80, no. 10: 20-23.

. "Primórdios do Adventismo no Brasil." Revista Adventista, January, 2005.

. "The Role of Ellen G. White in the Life of the Adventist Church." In Message, Mission, and Unity of the Church, edited by Ángel Manuel Rodríguez, 345-360. Silver Spring, MD: Biblical Research Institute, 2013.

. "The Sanctuary and the Three Angels' Messages, 1844-1863: Integrating Factors in the Development of Seventh-day Adventist Doctrines." PhD diss., Andrews University, 1995.

Tiplady, Richard. "Moravian Community, Spirituality, and Mission.” In Global Missiology for the 21st Century: The Iguassu Dialogue, edited by William D. Taylor, xi. Grand Rapids, MI: Baker Academic, 2000.

. One World or Many? The Impact of Globalisation on Mission. Globalization of Mission Series. Pasadena, CA: William Carey Library, 2003.

Tippett, Alan R. Introduction to Missiology. Pasadena, CA: William Carey Library, 1987. 
Tonetti, Márcio. "Passarela do Sábado.” Revista Adventista, September, 2006.

Town, N. Z. "The Literature Work in Brazil." Review and Herald, March 23, 1916.

Trousdale, Jerry. Miraculous Movements: How Hundreds of Thousands of Muslims Are Falling in Love with Jesus. Nashville, TN: Thomas Nelson, 2012.

Turner, Victor W. The Ritual Process: Structure and Anti-Structure. Symbol, Myth, and Ritual Series. Ithaca, NY: Cornell University Press, 1977.

“Um Ministério de Fé." Revista Adventista, June, 1992.

“União Central.” Revista Adventista, April, 1988.

Valle, Arthur S. "Audio-Visual Center Serves Evangelists." Review and Herald, July 22, 1976.

. "Manchetes da União Sul-Brasileira." Revista Adventista, November, 1969.

. "Penetration Is 1978 Goal." Review and Herald, August 18, 1977.

Van der Watt, J. G. Identity, Ethics, and Ethos in the New Testament. Beihefte Zur Zeitschrift FüR Die Neutestamentliche Wissenschaft Und Die Kunde Der äLteren Kirche. New York: Walter de Gruyter, 2006.

Van Rheenen, Gailyn. "The Changing Cultural Ethos of Latin America." Monthly Missiological Reflection (2002). Accessed April 23, 2010. www.missiology.org/ $\mathrm{mr}$-22-the-changing-cultural-ethos-of-latin-america/.

. "From Theology to Practice: The Helix Metaphor." Monthly Missiological Reflection, no. 25 (2002): 7-9. Accessed April 23, 2010. http://www.missiology .org/mr-25-from-theology-to-practice-the-helix-metaphor/

Vicenzi, Victor. História De Rio Dos Cedros. Blumenau, SC, Brazil: Fundação Casa Dr. Blumenau, 1975.

Vieira, C. Nunes "Rio De Janeiro on Fire for Evangelism." South American Division Bulletin, October-December, 1963, 3.

Vieira, Isabela. "Brasil Tem Três Chaves da Pós-Modernidade, Diz Sociólogo Francês," no. 5/28 (2014). Accessed 2015. http://agenciabrasil.ebc.com.br/cultura/noticia/ 2014-11/michel-maffesoli-brasil-tem-tres-chaves-da-pos-modernidade.

Vieira, Ruy Carlos de Camargo. Vida E Obra De Guilherme Stein Jr: Raizes da Igreja Adventista Do Sétimo Dia No Brasil. Tatuí, SP, Brazil: Casa Publicadora Brasileira, 1995. 
Viera-Rossano, Juan Carlos. "Seventh-day Adventists in Latin America: Their Beginnings, Their Growth, Their Challenges." DMiss diss., Fuller Theological Seminary, 1993.

“A Voz da Profecia.” Revista Adventista, April, 1943.

“A Voz da Profecia.” Revista Adventista, June, 1947.

"A Voz da Profecia: 40 Anos de Evangelismo Radiofônico.” Revista Adventista, September, 1983.

“A Voz da Profecia Irradiada na América Do Sul.” Revista Adventista, January, 1943.

Vyhmeister, Werner. “A Problem We Dare Not Ignore-1.” Adventist Review, November $5,1981,6$.

Waggoner, E. J. The Present Truth, January 24, 1895.

Walker, H. Eugene. "Medical Cadet Camp in North Brazil." Review and Herald, August $25,1955$.

Walls, Andrew. Cross-Cultural Process in Christian History: Studies in the Transmission and Appropriation of Faith. Maryknoll, NY: Orbis, 2002.

Walsh, Brian J., and J. Richard Middleton. The Transforming Vision: Shaping a Christian World View. Downers Grove, IL: InterVarsity Press, 1984.

Webster, F. C. "The Radio-TV Ministry in South America.” Review and Herald, April 21, 1966.

Westcott, H. B. “A Greatly Appreciated Layman.” Review and Herald, June 21, 1934.

Westphal, J. W. "Brazil.” Review and Herald, July 16, 1895, 1.

."Brazil." Review and Herald, October 13, 1904, 1.

. "Brazil, Uruguay, and Argentina." Review and Herald, October 1, 1895, 1.

. "Elder B. C. Haak.” Review and Herald, January 21, 1915.

. "General Meeting in the Sao Paulo (Brazil) Mission." Review and Herald, July 16, 1908.

."The South American Union Conference." Review and Herald, June 11, 1908. 
White, Cynthia. The Emergence of Christianity: Classical Traditions in Contemporary Perspective. Minneapolis, MN: Fortress Press, 2011.

White, Ellen G. The Acts of the Apostles. Mountain View, CA: Pacific Press, 1911. . "The Foreigners in America." Review and Herald, October 29, 1914, 3-4. . Gospel Workers. Washington, DC: Review \& Herald, 1915. . Testimonies for the Church. Vol. 9. Mountain View, CA: Pacific Press, 1948.

White, Ellen Gould. The Great Controversy between Christ and Satan. 11th ed. Mountain View, CA: Pacific Press, 1888.

White, James. Life Incidents. Battle Creek, MI: Steam Press: Seventh-day Adventist Publishing Association, 1868.

White, Stephen K. The Ethos of a Late-Modern Citizen. Cambridge, MA: Harvard University Press, 2009.

White, W. C. “The Argentine Republic.” The Home Missionary, II, June, 1890.

Wilcox, E. H. "The Bahia Mission, East Brazil." Review and Herald, February 2, 1928, 13. . "Reuniões Geraes em Matto Grosso.” Revista Adventista, September, 1934.

Williams, Andrew J. The Ethos of Europe: Values, Law and Justice in the EU. Cambridge Studies in European Law and Policy. New York: Cambridge University Press, 2010.

Williams, Rhys H. "Religious Social Movements in the Public Square." In A Handbook of the Sociology of Religion, edited by Michele Dillon, xiii New York: Cambridge University Press, 2003.

Wilson, Neal. "Global Mission: Person to Person.” Adventist Review, July 5, 1990.

Windisch, Hans. The Meaning of the Sermon on the Mount: A Contribution to the Historical Understanding of the Gospels and to the Problem of Their True Exegesis. Philadelphia, PA: Westminister Press, 1951.

Winter, Ralph D., and Bruce A. Koch. "Finishing the Task: The Unreached Peoples Challenge." In Perspectives on the World Christian Movement: A Reader, edited by Ralph D. Winter and Steven C. Hawthorne, xviii. Pasadena, CA: William Carey Library, 2009. 
Wolff, João. “A Blazing Continent.” Adventist Review, July 20-27, 1995, 10.

. "The Lord Has Done Great Things for Us." Adventist Review, July 1, 1985, 17-19.

."A Story of Gratitude and Praise.” Adventist Review, July 11, 1990, $22-24$.

World Council of Churches. "Seventh-day Adventist Church." Accessed September 5, 1014. http://www.oikoumene.org/en/church-families/seventh-day-adventistchurch.

Wright, J. F. "Evangelism in South America." Review and Herald, August 13, 1942, 24.

. "The Voice of Prophecy Broadcast-South America." Review and Herald, March 23, 1944, 19-20.

Wright, N. T. The New Testament and the People of God. Christian Origins and the Question of God. London: Society for Promoting Christian Knowledge, 1992.

What Saint Paul Really Said: Was Paul of Tarsus the Real Founder of Christianity? Grand Rapids, MI: W. B. Eerdmans, 1997.

Wright, Tom. Mark for Everyone. London: Society for Promoting Christian Knowledge, 2004.

Zald, Mayer N., and John D. McCarthy. Social Movements in an Organizational Society: Collected Essays. New Brunswick, NJ: Transaction Books, 1987.

Zdero, Rad. Nexus: The World House Church Movement Reader. Pasadena, CA: William Carey Library, 2007. 
Name: Marcelo E. C. Dias

Date of Birth: September 19, 1977

Place of Birth: Porto Alegre, RS, Brazil

Married: October 1, 2006 to Ana C. V. M. Dias

Child: Alissa Lauren Mainer Dias (2009)

\section{Education}

2009-2016 PhD in Religion (World Mission), Andrews University, Berrien Springs, MI

2001-2003 Master of Business Administration, La Sierra University, Riverside, CA

1998-2001 Bachelor of Arts in Theology and Bachelor of Science in Business Administration/Management Emphasis, Union College, Lincoln, NE

\section{Ordination}

2008, Dec 6 Ordained to the SDA Gospel Ministry

\section{Experience}

2015-Present Director, Center for World Missions (Numci), Brazil Adventist University (Unasp-EC)

2014-Present Coordinator, Master of Missiology, Latin-American Adventist Theological Seminary, Brazil Adventist University (Unasp-EC)

2009-Present Teacher of Practical Theology and Missiology, Latin-American Adventist Theological Seminary, Brazil Adventist University (Unasp-EC)

2007-2008 District Pastor, Parque dos Trabalhadores, Artur Nogueira, SP, Brazil

2004-2006 Assistant Pastor, Central Campinas Church, Campinas, SP, Brazil

2003-2004 Assistant Pastor, Taunton SDA Church, Taunton, MA, USA 